
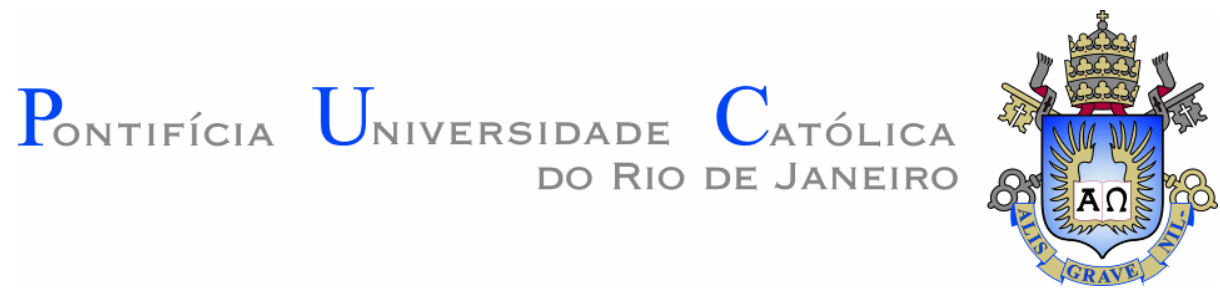

Flávia Hasky

\title{
A SOLIDÃO E O LAÇO COM O OUTRO EM TEMPOS DE CONECTIVIDADE Um estudo psicanalítico
}

\section{Tese de Doutorado}

Tese apresentada como requisito parcial para obtenção do grau de Doutora em Psicologia Clínica pelo Programa de Pós-Graduação em Psicologia Clínica do Departamento de Psicologia da PUC-Rio.

Orientadora: Profa. Maria Isabel de Andrade Fortes 
Flávia Hasky

\title{
A SOLIDÃO E O LAÇO COM O OUTRO EM TEMPOS DE CONECTIVIDADE \\ Um estudo psicanalítico
}

\begin{abstract}
Tese apresentada como requisito parcial para obtenção do grau de Doutora em Psicologia Clínica pelo Programa de Pós-Graduação em Psicologia Clínica do Departamento de Psicologia da PUC-Rio. Aprovada pela Comissão Examinadora abaixo.
\end{abstract}

Profa. Maria Isabel de Andrade Fortes

Orientadora

Departamento de Psicologia - PUC-Rio

Prof. Daniela Romão-Dias

Departamento de Psicologia - PUC-Rio

Prof. Marcus André Vieira Departamento de Psicologia - PUC-Rio

Prof. Rodrigo Cardoso Ventura Consultório de Psicanálise

Prof. Cláudia Braga de Andrade Escola de Educação - UNIRIO 
Todos os direitos reservados. A reprodução, total ou parcial, do trabalho é proibida sem autorização da universidade, da autora e do orientador.

Flávia Hasky

Psicóloga graduada pela UFRJ. Mestre em Teoria Psicanalítica pela UFRJ. Especializações em Clínica Psicanalítica e em Saúde Mental (Parceria com SMS/RJ) pelo IPUB/UFRJ.

Ficha Catalográfica

Hasky, Flávia

A Solidão e o Laço com o Outro em Tempos de Conectividade. Um estudo psicanalítico / Flávia Hasky; orientadora: Maria Isabel de Andrade Fortes. - Rio de Janeiro: PUC, Departamento de Psicologia, 2020.

240 f.; $29,7 \mathrm{~cm}$

1. Tese (doutorado) - Pontifícia Universidade Católica do Rio de Janeiro, Departamento de Psicologia.

Inclui referências bibliográficas.

1. Psicologia - Teses. 2. Internet. 3. Psicanálise. 4. Solidão. 5. Laço. I. Fortes, Maria Isabel. II Pontifícia Universidade Católica do Rio de Janeiro. Departamento de Psicologia. III. Título.

CDD: 150 
Dedico essa tese aos meus três grandes amores, Marcus, Laila e Leo, que fazem valer a cada dia a minha aposta no laço. 


\section{Agradecimentos}

A minha orientadora Isabel Fortes, agradeço imensamente, pela presença, pela descrição, pelo respeito ao meu trabalho como pesquisadora. Saio dessa experiência com uma enorme admiração por sua capacidade ímpar de nos conduzir da angústia ao trabalho. Muito obrigada. Sem você esse percurso teria sido bem mais penoso.

Ao Programa de Pós-Graduação em Psicologia da PUC-Rio agradeço pela excelente forma de organização e acolhimento dos alunos.

Agradeço ao $\mathrm{CNPq}$ pelo fornecimento da bolsa de incentivo a esta tese.

Ao meu marido Marcus, agradeço pelo amor, pela parceria, pelo incentivo constante, pela paciência e também pelas contribuições valiosas como professor. É muito bom te ter ao meu lado nessa travessia e na vida.

Aos meus filhos Laila e Leo agradeço por existirem, por encherem minha vida de sentido, de amor, de alegrias. Jamais me esquecerei dos desejos de "bom trabalho, mamãe!" e das carinhas sorridentes de vocês quando eu voltava para casa. Agora sim eu vou brincar muuuuuuuito!!

Aos meus amigos, pilares fundamentais da minha vida, agradeço por estarem sempre ao meu lado, enchendo-me de alegria e dando o gás necessário para que eu seguisse trabalhando.

Um agradecimento especial ao amigo Daniel Mograbi, pela torcida, pelos bons encontros, pelas informações preciosas. Foi uma grande alegria te reencontrar e podermos conviver um pouco mais perto novamente.

Ao amigo e padrinho de meus filhos, Rafael Viegas, agradeço pelo carinho de sempre e pelo apoio fundamental na reta final de conclusão deste trabalho. 
Aos coordenadores do Núcleo de Psicanálise e Medicina do ICP - Instituto de Clínica Psicanalítica da EBP-Rio em 2018 e 2019, Adriano Aguiar e Rodrigo Lyra e também aos colegas participantes, agradeço pelas instigantes discussões em torno do tema "O real no virtual: a psicanálise e a era das novas tecnologias".

Agradeço à minha analista Marcia Zucchi por me oferecer este espaço único, em que pude endereçar minhas angústias e seguir alimentando meu desejo de pesquisar e de escrever essa tese. Sua escuta e seus comentários foram fundamentais para eu chegar até aqui.

Aos meus pais, agradeço pelo que puderam me dar e também pelo que não me deram e me fizeram ir buscar.

Faço questão de registrar aqui um carinho especial ao meu pai, que nos deixou em 2016, no início de minha trajetória no Doutorado. A você, meu eterno amor e votos de que descanse em paz. 


\section{Resumo}

Hasky, Flávia; Fortes, Maria Isabel de Andrade. A Solidão e o Laço com o Outro em Tempos de Conectividade. Um estudo psicanalítico. Rio de Janeiro, 2020. Tese de Doutorado - Departamento de Psicologia, Pontifícia Universidade Católica do Rio de Janeiro.

Inserida no campo de estudos sobre tecnologia e subjetividades, a presente tese consiste em um estudo psicanalítico dedicado à investigação das interfaces entre sociabilidade e cultura digital. Refletindo acerca das incidências da internet sobre os sujeitos tanto no que diz respeito à lida de cada um consigo mesmo, quanto aos relacionamentos interpessoais, focamos este estudo nas repercussões dessa novidade nas formas como vivenciamos as dimensões da solidão e do laço com o outro. Partindo de situações da clínica e da cultura contemporânea dedicamo-nos a pensar sobre os novos modos de interação consigo e de vínculo com o outro que têm na internet e nas máquinas figuras-chave, visando proporcionar novas possibilidades de leitura e de manejo frente aos desafios surgidos nos hiperconectados anos 2000. Através da ênfase nas coexistências, nas complexidades e nos paradoxos, assim como na possibilidade da rede virtual se prestar a múltiplos usos, intencionamos desconstruir a visão dicotômica ainda marcante neste campo de estudos, apresentando uma perspectiva que pensa a rede como um lugar em que manifestações eróticas podem tanto se presentificar quanto se mostrarem escassas. Sobre as temáticas da solidão e do laço com o outro a tese apresenta pressupostos psicanalíticos construídos por Freud e por Lacan acerca dessas dimensões da vida humana, com vistas a oferecer o embasamento teórico necessário para refletirmos a esse respeito em tempos de conectividade. Com relação à Era Digital, exploramos os desdobramentos da aplicação das tecnologias digitais à vida amorosa das pessoas, assim como a produção de "novas" solidões marcadas pelo uso maciço da internet.

\section{Palavras-chave}

Internet; Psicanálise; Solidão; Laço 


\section{Abstract}

Hasky, Flávia; Fortes, Maria Isabel de Andrade (Advisor). Loneliness and the Bond with Others in Times of Connectivity: A Psychoanalytic Study. Rio de Janeiro, 2020. Tese de Doutorado - Departamento de Psicologia, Pontifícia Universidade Católica do Rio de Janeiro.

Inserted in the field of technology and subjectivity studies, this thesis consists of a psychoanalytic study dedicated to the investigation of the interfaces between sociability and digital culture. Reflecting on the incidences of the internet on the subjects, both with regard to the intrapersonal, as well as interpersonal relationships, we focus this study on the repercussions of this novelty in the ways we experience the dimensions of loneliness and the bond with others. Starting from clinical and contemporary cultural situations, we dedicate ourselves to thinking about the new ways of interacting with ourselves and bonding with others on the internet and other modern machines, aiming to provide new possibilities for understanding and handling the challenges which have emerged in the hyperconnected 2000s. Through the emphasis on coexistences, complexities and paradoxes, as well as the possibility of the virtual network having multiple uses, we intend to deconstruct the dichotomous vision still strong in this field of studies, presenting a perspective that thinks the network as a place where erotic manifestations can be both present and scarce. On the themes of loneliness and bonding with others, the thesis presents psychoanalytical assumptions built by Freud and Lacan about these dimensions of human life, with a view to offering the necessary theoretical basis to reflect on this in times of connectivity. With regard to the Digital Era, we explored the consequences of the application of digital technologies to people's love lives, as well as the production of "new" solitudes marked by the massive use of the internet.

\section{Keywords}

Internet; Psychoanalysis; Loneliness; Bond 


\section{Resumé}

Hasky, Flávia; Fortes, Maria Isabel de Andrade (directrice de thèse). La solitude et le lien à l'autre en temps de connectivité: une étude psychanalytique. Rio de Janeiro, 2020. Tese de Doutorado - Departamento de Psicologia, Pontifícia Universidade Católica do Rio de Janeiro.

Insérée dans le champ d'études sur la technologie et les subjectivités, la présente thèse consiste dans une étude psychanalytique consacrée à l'investigation des interfaces entre la sociabilité et la culture numérique. En réfléchissant sur les effets de l'internet sur les sujets aussi bien dans leurs rapports à eux-mêmes que dans leurs rapports aux autres, nous centrons cette étude sur les répercussions de cette nouveauté sur les façons dont nous vivons les dimensions de la solitude et du lien à l'autre. En partant de situations de la clinique et de la culture contemporaine, nous nous consacrons à penser les nouveaux modes d'interaction à soi et d'attachement à l'autre qui ont comme figures clés l'internet et les machines, afin de procurer de nouvelles possibilités de lecture et de maniement face aux défis posés par les hyperconnectés des années 2000. En soulignant les coexistences, les complexités et les paradoxes, aussi bien que la possibilité que le réseau internet se prête à de multiples usages, nous envisageons déconstruire l'approche dichotomique encore remarquable dans ce champ d'études, en présentant une perspective qui prend le réseau comme un endroit où les manifestations érotiques peuvent aussi bien se rendre présentes que s'avérer rares. Sur les thématiques de la solitude et du lien à l'autre, cette thèse présente des présupposés psychanalytiques érigés par Freud et par Lacan autour de ces dimensions de la vie humaine, afin d'offrir la base théorique nécessaire à la réflexion à ce propos en temps de connectivité. Par rapport à l'Âge Numérique, nous explorons les conséquences de l'application des technologies numériques à la vie amoureuse des gens, de même que la production de "nouvelles" solitudes marquées par l'usage intensif de l'internet.

\section{Mots-clés}

Internet; Psychanalyse; Solitude; Lien 


\section{SUMÁRIO}

$\begin{array}{ll}\text { Introdução } & 11\end{array}$

1. A Internet e seus múltiplos usos. Desconstruindo uma visão dicotômica 23

1.1. "Apocalípticos e integrados": uma inspiração, uma referência 24

1.2. Erotismo e escassez na era da internet: o debate entre Pitliuk e Birman 28

1.3. A novidade internet e suas diferentes recepções 36

1.4. As tecnologias digitais e seus múltiplos usos $\quad 42$

1.4.1. Exemplos variados da cultura 50

1.5. A internet pela via da complexidade e dos paradoxos 53

1.6. Real e Virtual entrelaçados: mundo online e mundo off-line como um contínuo

1.6.1. A Banda de Moebius como recurso topológico para pensar esse contínuo 67

1.7. Os psicanalistas frente aos laços virtuais: posicionamentos em curso $\quad 71$

2. A solidão e o laço com o outro a partir de Freud e de Lacan 77

2.1. Solidão em tempos de conexão

2.2. A solidão estrutural $\quad 80$

2.3. O desamparo segundo Freud 85

2.4. A linguagem em Lacan 92

2.5. Do desamparo à dependência: complexidades entre o sujeito e o outro 98

2.6. O laço com o outro 106

3. A comunicação digital entre os seres falantes. A tecnologia aplicada à vida amorosa e sexual

3.1. De onde partimos 136

3.2. "Novas solidões" da Era da internet 139

3.3. Uma rede que faz laço, uma rede que isola 152

3.4. A internet como "ilusão protetora" 172

3.5. O mal-estar na comunicação: o real no virtual 182

3.6. Aplicativos de encontro e desencontro 200

3.7. A comunicação digital entre um ser falante e uma máquina 202

4. Considerações finais 220

$\begin{array}{ll}\text { 5. Referências bibliográficas } & 229\end{array}$ 
Podemos ver o mundo juntos Sermos dois e sermos muitos Nos sabermos sós sem estarmos sós

Caetano Veloso, Tá combinado 


\section{INTRODUÇÃO}

Os novos dispositivos das tecnociências transformaram radicalmente, em poucos anos, o mundo em que vivemos. Dentre todas as novas tecnologias, as que envolvem as relações e experiências virtuais são as que dominam inegavelmente o cenário contemporâneo. A partir do advento da internet e de sua veloz e espantosa difusão, passamos a viver em um contexto de expansão crescente do ciberespaço, no qual observamos e experimentamos transformações radicais nos mais diversos âmbitos, como o político, o econômico, o social e o comportamental. Dentre as esferas da atividade humana às quais o escopo do uso dos computadores foi ampliado, elegemos estudar nesta pesquisa as tramas tecidas entre tecnologia e subjetividade.

Neste novo cenário em que figuram as subjetividades contemporâneas atravessadas pela tecnologia, interessou-nos investigar particularmente as interfaces entre sociabilidade e cultura digital. Buscamos refletir sobre as incidências da internet sobre os sujeitos, isto é, tanto no que diz respeito à lida de cada um consigo mesmo, quanto aos relacionamentos interpessoais. Assim, em meio à vastidão de temas que a internet engloba, focamos nosso estudo nas incidências dessa novidade nas formas como vivenciamos as dimensões da solidão e do laço com o outro.

A questão de pesquisa nasceu da clínica, da escuta de pacientes das mais diversas faixas etárias, que passaram a trazer para a análise com bastante frequência situações, dúvidas, conflitos e sofrimentos em que a rede virtual se fazia presente. A partir daí foi sendo avivado o desejo de nos lançarmos em uma investigação teórica aprofundada, de nos dedicar ao trabalho tão fundamental à psicanálise, de entrelaçamento entre clínica e teoria. Pacientes como a jovem Ana, através de frases como "Meu ego é movido a Facebook", "Estou à espera de uma foto pra causar" ou "será que todo mundo acha que eu não estou bem porque não estou postando nada no Face? Tô morta! Minha página está em branco, o vazio é real" foram nos fazendo perceber que ser visto e curtido em fotos espetaculares nas redes sociais tem pautado existências.

Pouco a pouco, começamos a nos perguntar que desdobramentos poderíamos dar a falas como as de Ana. O que estariam nos dizendo sobre a cultura digital em que vivemos os sujeitos que dão testemunho sobre isso em seus 
tratamentos psicanalíticos? De que forma nomes como Facebook, Twitter, Instagram, Whatsapp, Tinder têm aparecido nas sessões? Para onde apontam, em termos de consequências para aquele que sofre e vem em busca de uma análise? Passado um primeiro tempo de interrogações e estudos, chegamos ao recorte que hoje dá corpo a esta tese, o qual propõe explorar, como já dito, as relações entre a internet e a subjetividade, isto é, de que formas o surgimento da internet e seus múltiplos usos transformou nossa relação com os outros e com nós mesmos. Trata-se, portanto, de uma pesquisa dedicada a pensar sobre os novos modos de interação consigo e de vínculo com o outro, que têm na internet e nas máquinas figuras-chave.

A comunicação corrente em redes virtuais é uma questão que se encontra no coração de nossa atualidade. As tecnologias digitais de comunicação e informação e seu uso maciço tem afetado consideravelmente o sujeito, em seu modo de vida e em suas relações. São muitos os aplicativos e as redes sociais que vêm transformando a maneira com a qual nos posicionamos no mundo e nos relacionamos, incidindo sobre as formas de constituição do laço social. Interagimos com saberes, imagens, informações, pontos de vista e também com pessoas, já conhecidas ou não. "A rede mundial de computadores se tornou um grande laboratório, um terreno propício para experimentar e desenvolver novas subjetividades e outras formas de se relacionar com os demais" (Sibilia, 2016, p. 52). Atualmente, casais formados a partir de sites de relacionamentos, aplicativos de encontros ou trocas via redes sociais são cada vez mais comuns, fazendo-nos constatar que "a internet trouxe para a comédia dos sexos um novo motor de buscas de uma parceria amorosa" (Veras, 2015b, p. 199). Além disso, basta olharmos para o lado, aonde quer que estejamos - no metrô, num restaurante, nas ruas ou mesmo em casa - e certamente nos depararemos com alguém teclando, como forma de interagir com amigos, amores ou mesmo com a incomensurável massa virtual de interlocutores anônimos.

Um movimento geral de virtualização afeta hoje a informação, a comunicação e os corpos. Há uma novidade radical na relação contemporânea com o conhecimento, assim como as modalidades do estar junto também são atingidas. Nunca antes as mudanças das técnicas, da economia e dos costumes foram tão rápidas e desestabilizantes, fazendo com que a 'Era da Internet' ou 'Era do acesso' seja um exemplo único na história da humanidade, fruto de uma 
inovação técnica que se globalizou tão rapidamente. Michel Serres, filósofo francês autor de "Polegarzinha" (2013), define o momento atual como uma "terceira revolução", que faz série com as duas outras que atingiram as sociedades ocidentais: a da transição do oral para o escrito e, em seguida, do escrito para o impresso. Essa terceira, igualmente crucial, vem acompanhada por mudanças políticas, sociais e cognitivas. Romão-Dias e Nicolaci-da-Costa (2012) afirmam o mesmo, ao definirem a internet como "a mais revolucionária invenção tecnológica desde a Revolução Industrial” (Romão-Dias, Nicolaci-da-Costa, 2012, p. 86). A inevitabilidade da web é um dado que passou a figurar em afirmativas de diversos autores, como podemos observar, por exemplo, nas palavras de Veras: "os encontros virtuais vieram para ficar"; "assim como foi com a geladeira e com a televisão, não há mais um lar sem computador" (Veras, 2015b, p. 201).

Um ponto fundamental do sujeito e de suas relações é a palavra e seu uso cotidiano. A união entre o poder da palavra e o poder dessas redes virtuais que atraem milhares de pessoas é um rico cenário para aqueles que lidam com o sujeito e seu discurso. "Quando o poder da palavra se junta ao poder da web, criase uma força maior do que tudo o que já vimos. Isso é ao mesmo tempo aterrorizador, sedutor e lindo, como a nuvem em forma de cogumelo de uma bomba" (Ronai, 2006, p. 13). Tema extremamente atual e instigante, interessa à psicanálise dado o reconhecimento do vínculo necessário entre teoria e clínica psicanalíticas e os contextos sócio históricos nos quais se inserem. Acreditamos que para que a psicanálise siga atual e a serviço daqueles que sofrem na atualidade, o psicanalista precisa "saber orientar-se na sociedade em que vive e trabalha" (Tizio, 2011, p. 316). Essa referência à cena social é fundamental para que sigamos nos perguntando vivamente de que formas o texto psicanalítico pode incidir no contexto.

"Nesse espaço metamorfoseado pelo poder irresistível dos objetos virtuais" (Santiago, 1997, p. 74) insere-se essa pesquisa, que tem sua origem no aspecto da psicanálise que pensa a sociedade e os fenômenos de uma época. Um estudo psicanalítico sobre as incidências da internet na solidão e no laço com o outro poderá, a nosso ver, proporcionar novas chaves de leitura e de manejo frente às novidades que surgiram nos hiperconectados anos 2000. Em consonância com o que propõe Miller (2016) a respeito da atuação dos psicanalistas no "império da técnica" que hoje abrange todo o planeta, não podemos desistir de dialogar com as 
novidades tecnológicas, "elas exigem da psicanálise interpretação" (Miller, 2016, p. 23). Seguiremos, então, este alerta de Miller, diante do desafio que se coloca hoje, para a psicanálise, de escutar o sujeito do nosso contemporâneo, não recuando de apostar nas ferramentas freudianas e lacanianas para intervir psicanaliticamente em nosso mundo.

A psicanálise, desde Freud, nasceu pela via da afinidade com aquilo que não tinha resposta pronta nem pré-determinada. Este é um de seus pilares: a verdade vem sempre em uma posteridade e não de antemão. Por isso mesmo, diante das diversas mutações e dos estilos e práticas de vida, sua sustentação teórica e o delineamento de suas ferramentas clínicas estão também sempre em permanente transformação. Nesse sentido, nos guiamos ao longo de toda a pesquisa pela função da psicanálise de não responder, mas sim de manter aberta uma discussão. Tomando clínica e política como indissociáveis, há uma reinvenção que se dá em conexão com os impasses da civilização. Assumindo a responsabilidade de participar dos fenômenos culturais e sociais de nossa época, acreditamos que a psicanálise deve se inserir nas discussões acerca dos impactos das tecnologias digitais da comunicação para a sociedade, por se tratar de um problema do mundo que exige um posicionamento do sujeito.

Investigar, a partir do referencial teórico-clínico da psicanálise, como o uso maciço da internet na contemporaneidade incide sobre o sujeito, especialmente no que tange à solidão e ao laço social, é o desafio instigante ao qual pretendemos nos lançar na presente tese. Considerando a internet como "uma nova plataforma de vida: novo suporte para as atividades e paixões humanas" (Nicolaci-da-Costa, 2006, p. 29), procuraremos refletir mais especificamente sobre o campo dos relacionamentos, por ser tanto um campo que sofreu profundas mudanças com a hiperconectividade, quanto uma dimensão da vida humana de enorme interesse para a psicanálise desde o seu nascimento.

Em termos históricos, é importante mencionar que a internet é considerada como "a maior revolução já vista na forma de comunicação interpessoal" (Pedreira, 2006, p. 43). Relatos sobre seus primórdios destacam o espanto diante desta novidade, boa parte relacionado à grandiloquência que tal inovação já anunciava, no ano de 1993. Como relata Pedreira (2006): "comecei a ouvir falar de alguma coisa muito louca que prometia revolucionar a maneira como as pessoas se comunicariam pelos próximos anos. Através de uma rede de 
computadores, as pessoas poderiam trocar informações, estudar, bater papo, enfim, elas estariam mais próximas, mesmo estando a milhares de quilômetros de distância! Essa proximidade se daria a um nível tão intenso que nada seria comparável a essa novidade" (p. 41). Em seu artigo, a autora brasileira refere-se à web como "aquela coisa inimaginável", "uma experiência tecno-transcendental!", descrições que nos chamam a atenção e se assemelham àquela comentada pelo historiador israelense Harari (2016), que se deparou com a internet pela primeira vez no mesmo ano. Diante do anúncio de um colega da área de informática de que tinha conseguido conectar seu computador ao computador central da universidade, Harari perguntou o que tinha neste tal computador central. A resposta que recebeu foi reveladora: "ainda não tem nada. Mas dá para pôr todo tipo de coisas lá” (Harari, 2016, p. 58).

Dada a revolução ocasionada pela criação desta rede, vivemos um novo capítulo da história, o que é apontado por diversos autores que trabalham com esta hipótese (Sibilia, 2016; Guillebaud, 2015; Serres, 2013; Harari, 2016, Dessal, 2017b). A esse respeito, Dessal (2017b) sublinha que "a cultura da internet chegou para modificar definitivamente o curso da história da humanidade" (p. 14). Na visão de Sibilia (2016) "está ocorrendo uma mudança de regime, isto é, uma verdadeira mutação histórica no campo das subjetividades, no tipo de relação que podemos ter conosco, com os outros e com o mundo" (Sibilia, 2016, p. 333). Esta autora destaca o quão radicais são as mudanças que estamos experimentando, falando-nos de uma verdadeira metamorfose.

Gostaríamos de comentar, desde já, que mesmo concordando com a radicalidade das mudanças e com esta visão de que vivemos um corte na história da humanidade, desejamos sustentar ao longo da tese que há uma tensão permanente entre o que persiste e o que muda, ao menos nos âmbitos da solidão e dos laços entre as pessoas. Nem tudo é novo, nem tudo está igual. Autores como Gonçalves (2006) nos auxiliam a pensar por essa via, por proporem "pensar não apenas numa perspectiva que considera a revolução, corte, mas também as continuidades" (Gonçalves, 2006, p. 231). O corte seria relativo, pois o antigo permanece, as mudanças convivem com permanências (idem). "Se há novo, há também reatualização do antigo ${ }^{1 "}$ (p. 240).

\footnotetext{
${ }^{1}$ É curioso observar como essa questão das permanências ou novidades é abordada pela via do humor. Uma charge que circulou pelas redes virtuais intitulada "Os 7 pecados atuais" brincava
} 
Em termos de organização, dividimos nosso estudo em três capítulos: o primeiro expõe a abordagem a partir da qual trabalhamos a temática da internet em nossa pesquisa, ou seja, abre a tese situando o leitor sobre a forma como nos inserimos nas reflexões sobre a internet e seus impactos. O segundo capítulo objetiva apresentar como a solidão e o laço com o outro foram pensados por Freud e por Lacan. Já o terceiro, que interliga os dois primeiros, explora as incidências da comunicação digital nestes âmbitos da vida humana aos quais elegemos nos dedicar.

Para introduzir o capítulo de abertura, uma pergunta: "Um mundo com 30 bilhões de dispositivos conectados à Internet assusta ou anima você ${ }^{2}$ ”. Esta e outras perguntas recorrentemente divulgadas pelas mais diversas mídias apontam para a duplicidade de posições face à explosão do digital. O primeiro capítulo da tese dedica-se à discussão dessa duplicidade de posições, ou seja, à tendência a polarizações ainda marcante neste campo de estudos. Através da ênfase nas coexistências, nas complexidades e nos paradoxos, assim como na possibilidade da rede se prestar a múltiplos usos, intencionamos desconstruir essa visão dicotômica e apresentar uma perspectiva que pensa a rede como um lugar em que manifestações eróticas podem tanto se presentificar quanto se mostrarem escassas.

Partindo da constatação de que "não dá mais para voltar atrás" e de que, portanto, é inútil demonizar a internet, apostamos nessa via, que nos pareceu mais rica e interessante: a de explorar o que fazemos da rede, na rede, com a rede, isto é, o que ela faz de nós e em nós, visando decifrar suas consequências, compreender melhor suas incidências nas subjetividades contemporâneas. Questionamentos que se endereçam ao âmbito das singularidades, como os que expomos a seguir, norteiam a escrita deste capítulo e a tessitura de toda a tese. Como cada usuário se apropria da internet? Quão múltiplos podem ser os usos da rede para cada sujeito e que efeitos têm na lida destes com sua própria solidão? O

com a possibilidade de associar cada um dos pecados capitais clássicos a um aplicativo digital. São eles: Gula - ifood; Preguiça - Netflix; Ira - Twitter; Luxuria - Tinder; Soberba - Linkedin; Inveja - Facebook; Vaidade - Instagram.

2 Pergunta que abria a página do Mozilla em setembro de 2017, pedindo uma resposta dos usuários.

${ }^{3}$ Aspecto apontado por diversos pensadores contemporâneos, dentre os quais destacamos aqui o filósofo americano Jordan Shapiro, que em matéria no jornal "O Globo" de 05 de janeiro de 2020 afirmou: "não vamos nos livrar dos smartphones, o que talvez até seja um erro, talvez seja terrível viver num mundo conectado. Mas o gênio está fora da lâmpada” (p. 40). 
que pensar sobre os sujeitos e os vínculos que vão sendo inventados a partir desse engajamento no discurso digital?

O segundo capítulo dedica-se ao estudo dos pressupostos psicanalíticos construídos por Freud e por Lacan acerca da solidão e dos relacionamentos, com vistas a nos oferecer o embasamento teórico necessário para refletirmos sobre estas temáticas em tempos de conectividade. Nesta parte da tese retornamos aos ensinamentos destes dois autores buscando nos servir de suas conceituações a respeito dos homens e de suas formas de fazer laço com o outro para pensar o contexto atual, em que a interconexão através das redes virtuais se tornou tão corriqueira. A nosso ver, só assim poderíamos levar a cabo essa pesquisa, ou seja, só assim poderíamos sustentar um pensamento psicanalítico voltado para as questões atuais, com todo o rigor acadêmico que isto requer. Queremos dizer com isso que apenas a partir do estudo dedicado ao legado que nos deixaram sobre a constituição do sujeito e do laço com o outro é que obtivemos condições de pensar as especificidades disso em nossos dias. Sendo a internet um dos "teatros da sociabilidade contemporânea" (Sibilia, 2016, p. 335), a indagação que permeou este capítulo foi sobre como o recurso a noções-chave do saber psicanalítico pode contribuir para compreendermos e lidarmos com os personagens dessa cena virtual.

Desde já é preciso deixar claro que só aprofundamos a teoria de Freud e de Lacan o suficiente para dar ao leitor recursos teóricos para nos acompanhar nos demais capítulos. Ou seja, trabalhamos conceitos das obras de ambos os autores como a solidão estrutural, correlata ao desamparo constitutivo; a fragilidade humana; o mal-estar ineliminável; as consequências de sermos seres marcados pela linguagem; a impossibilidade de um encontro completo com o outro; o amor tomado como solução, porém não-toda - naquilo que se articulam com o objeto de estudo central da tese, sem buscar ir a fundo e explorar minuciosamente cada noção, conceito ou postulado.

O terceiro e último capítulo desta tese será dedicado a pensar sobre a solidão e o laço com o outro em meio à comunicação digital. Retomaremos conceituações desenvolvidas no capítulo anterior, articulando-as com as novidades promovidas pelo advento da internet. Assim, nossa proposta é recorrer às considerações de Freud e de Lacan sobre a solidão e o laço com o outro visando pensar sobre tais temáticas no cenário atual. Exploraremos os 
desdobramentos da aplicação das tecnologias digitais à vida amorosa das pessoas, assim como a produção de "novas" solidões marcadas pela novidade da internet. Veremos que as redes virtuais têm a potencialidade de promover laços assim como de isolar os sujeitos e que os aplicativos de encontro são também de desencontro. Discutiremos a questão referente à possibilidade de a internet poder ou não funcionar como uma ilusão protetora e apresentaremos a hipótese psicanalítica de pensar o mal-estar na comunicação, ao localizar incidências do registro do real (no sentido lacaniano) também no ambiente virtual. Por fim, refletiremos sobre as situações em que a comunicação se dá entre um ser falante e uma máquina - computador ou celular - ocupando o papel do outro (será?!), extraindo as consequências subjetivas desta nova prática.

Sobre este último ponto vale destacar que a existência e a popularização dos smartphones têm íntima relação com a questão de pesquisa que nos capturou e nos pôs a trabalhar. Equipamentos básicos e imprescindíveis de grande parte da população mundial, esses aparelhos trouxeram consequências gigantescas e implicações diretas no enfrentamento de cada um de nós de nossa condição solitária. Essa miniaturização dos aparelhos eletrônicos, que promoveu uma facilitação em sua incorporação, não apenas ao nosso cotidiano, mas também ao corpo humano, trouxe, a nosso ver, novas e instigantes questões. A possibilidade de termos acesso à rede a qualquer hora, de qualquer lugar, interfere enormemente na forma com que lidamos com nossa própria solidão, assim como na forma com que nos dirigimos ao outro. A existência dessa fonte inesgotável de prazer imediato que está literalmente ao alcance da sua mão 24 horas por dia impacta diretamente os campos da vida humana que elegemos investigar.

Os dispositivos portáteis que agora todos levamos conosco a toda parte, não só nos permitem como também nos estimulam a estar em contato permanente com as demais pessoas. Ao mesmo tempo, por vezes tornam-se tão atraentes que nos esquecemos das pessoas que estão ao nosso lado. Esse aspecto paradoxal que nos intrigou e será trabalhado na tese, aparece também nos dados apresentados por Lima (2016) a partir de entrevistas que buscavam investigar a relação dos jovens com seus aparelhos de telefone celular. Seguem as respostas por ela encontradas: "Não consigo ficar sem o celular"; "se me tirarem o celular eu fico doida"; "não desgrudo do celular"; "minha vida tá toda aí"; "ele é tudo pra mim" (Lima, 2016, p. 120); “precisam[os] olhar a todo instante se alguém postou 
alguma coisa nas redes sociais, é algo incontrolável” (p. 121); "quando a gente fica sem internet é que percebe que tem pai e mãe"; "sem celular eu me sentia 'um nada"” (p. 131).

Por fim, nesta introdução, gostaríamos de tratar ainda de dois aspectos gerais que marcam esta pesquisa. Primeiramente, é preciso explicitar seu traço interdisciplinar, justificado pela complexidade e pela abrangência do tema. Sobre a importância desse tipo de abordagem e sua especial pertinência dado o tema de pesquisa por nós eleito, nos diz Lima: "O estudo das subjetividades no contexto da cultura digital requer um debate cada vez mais intenso entre as áreas do conhecimento" (Lima, 2017, p. 08). Assim, para além das abordagens propriamente psicanalíticas, traremos considerações de autores de áreas afins como comunicação, filosofia, antropologia e história - já que nosso objeto de estudo exige para uma compreensão mais completa, a nosso ver, uma abordagem interdisciplinar.

O outro ponto que gostaríamos de comentar diz respeito à atualidade do tema. Pesquisar um assunto da contemporaneidade era algo que nos encantava desde os primeiros movimentos que esboçamos rumo à entrada no Doutorado. E, à medida que começamos as leituras fomos tendo clareza de que toda investigação sobre a rede mundial de computadores e seus desdobramentos no campo subjetivo traz consigo a peculiaridade de "termos pouca distância das transformações ainda em curso, nas quais nós próprios estamos imersos". Entendemos, com Harvey e outros autores, que "nunca é fácil elaborar uma avaliação crítica de uma situação avassaladoramente presente" (Harvey, 1999, p. 301 apud Romão-Dias, Nicolacida-Costa, 2005, p. 86). Topamos o desafio e seguimos considerando-o difícil e ao mesmo tempo fascinante, até o final do percurso de trabalho.

Um último acontecimento veio para não deixar dúvidas quanto à atualidade e também à importância de discutirmos a temática da internet e suas potencialidades para a vida dos seres humanos. Não teríamos como introduzir esta tese sem mencionar a pandemia do coronavírus, que nos pegou de surpresa e sobressalto em 2020 depois de já termos escrito praticamente todo o trabalho. Com a orientação de que ficássemos em quarentena, com a circulação restrita, isolados em nossas casas, o papel que a internet tem nos laços que mantemos uns com outros ficou mais que evidente. Apaziguados com a possibilidade de estarmos "distantes, mas juntos" devido à existência da comunicação digital, 
vimo-nos, sem dúvida alguma, diante de situações inéditas. Novas perguntas surgiram, novas experiências incluindo o uso da rede foram inauguradas, mobilizando a todos e a nós, sobremaneira, enquanto pesquisadoras e sujeitos. Impactados, lembramo-nos de uma colocação de Miskolci (2017), em que dizia que "vivemos em uma nova esfera relacional, cujos horizontes, regras e também limitações estamos descobrindo ao mesmo tempo em que nela adentramos" ( $p$. 22). Nunca poderíamos imaginar que nesta reta final estaríamos tão dentro do tema de pesquisa que escolhemos trabalhar há cinco anos!

Essa rapidez com que as mudanças acontecem gera até mesmo um medo curioso de que esta tese se torne obsoleta em poucos anos. Não seria difícil imaginar que algo que em 2020 seguia nos fazendo questão venha a se tornar óbvio e naturalizado em pouco tempo, por exemplo. Todavia, diferentemente dos gadgets, caso isso ocorra, será uma obsolescência não programada ${ }^{4}$, decorrente do risco inerente à natureza da pesquisa. Como bem coloca Dessal (2017b), "a técnica se move a uma velocidade maior que nossa capacidade de nos adaptarmos a ela, para assumir suas mudanças e suas consequências" (...) "a distância entre o que a ciência aplicada produz e nossa possibilidade de refletir sobre isso aumenta progressivamente" (Dessal, 2017b, p. 02). Essa tese nasce nesse intervalo, habita essa distância, se localiza nesse 'entre', explora esse espaço.

Antes de partirmos para o primeiro capítulo desejamos compartilhar uma sensação forte que experimentamos justamente nos momentos de escrita da tese e que testemunha, na carne, os efeitos de nosso objeto de pesquisa. Foi impressionante a diferença de ler a bibliografia e de escrever este trabalho estando ou não com o celular na mesa da biblioteca! Nos momentos em que optei ou precisei deixá-lo por perto, acabava checando-o e, naturalmente, me desconcentrando. Em outras ocasiões (que se tornaram quase norma) criei uma estratégia meio tosca, porém necessária, de trancar o 'aparelhinho' no locker e só consultá-lo nos intervalos. Tal hábito me fez pensar ainda mais: o que ocorre comigo e com muita gente quando o celular está ali ao lado, ao alcance das mãos? Passei então a nomear meu telefone como "essa coisa perturbadora", inspirada nesta indicação deixada por Lacan, que já em 1974 nos falava da novidade e das

\footnotetext{
${ }^{4}$ Criamos esse paralelo jocoso com o fenômeno da obsolescência programada, definido como a "decisão proposital de um fabricante de produzir um objeto que se torna obsoleto ou não funcional após certo prazo, a fim de forçar o consumidor a comprar a "nova geração" do produto" (Jerusalinsky, 2017, p. 16). Obsolescência como sinônimo de não permanência.
} 
reviravoltas introduzidas pela ciência, trazendo "um monte de coisas perturbadoras na vida de todos" (Lacan, 1974/2005, p. 65). É também dele o questionamento que transcrevo a seguir, igualmente surpreendente por sua atualidade: "O futuro da psicanálise depende do que advirá desse real. As bugigangas, por exemplo, realmente tomarão a dianteira? Chegaremos a nos tornar, nós mesmos, verdadeiramente animados pelas bugigangas?” (Lacan, 1974, p. 33).

Enfim, partindo de articulações entre a teoria psicanalítica e aquelas destinadas a pensar a "Era Digital", almejamos trazer novas contribuições acerca de sujeitos desamparados em um mundo conectado, que possam se somar a de outros psicanalistas que vêm se debruçando sobre o tema. Que consequências teóricas e articulações com a prática podem ser retiradas do interesse de Veras (2015) “por aquilo que na rede não serve para comunicar” (Veras, 2015a, p. 13)? Já que "a psicanálise nos mostra que, para além da função de comunicação, a linguagem inclui o gozo" (Lima, 2016, p. 113), cabe-nos investigar o que resta não conectado, acossando o sujeito contemporâneo, para além da pergunta recorrente e "fundamental" de nossos dias, "qual a senha do wifi?". Embalados pela canção de Gilberto Gil - "Estou preso na rede que nem peixe pescado"; "Agora é terabyte que não acaba mais por mais que se deseje. Que o desejo agora é garimpar nas terras das Serras Peladas virtuais" ("Pela internet 2", música de 2018) - e atentos ao exercício desafiador de nos colocar novas e boas questões, que gerem enigmas e que nos mantenham curiosos, seguimos adiante. 


\title{
CAPÍtULO 1 \\ A INTERNET E SEUS MÚLTIPLOS USOS DESCONSTRUINDO UMA VISÃO DICOTÔMICA
}

\author{
Ou isto ou aquilo: ou isto ou aquilo ... e vivo \\ escolhendo o dia inteiro! \\ Não sei se brinco, não sei se estudo, se saio \\ correndo ou fico tranquilo. \\ Mas não consegui entender ainda qual é melhor: \\ se é isto ou aquilo.
}

Cecília Meireles, Ou isto ou aquilo

Neste capítulo de abertura da tese desejamos apresentar como se situa a presente pesquisa no campo dos estudos sobre a internet, visando delimitar algumas contribuições para o debate a respeito do virtual e seus destinos, a partir de uma interlocução com a psicanálise. Assim, propomos, nessa abertura, problematizar a posição dicotômica que marca o campo de saberes do estudo eleito. De saída, buscamos nos distanciar de qualquer dicotomia entre X e Y, para propor outros parâmetros de pensabilidade sobre a internet. As páginas que se seguem visam, portanto, explicitar a partir de quais pressupostos construímos nossa abordagem relativa à questão central desta tese, a saber, a solidão e o laço com o outro em tempos de conectividade, segundo uma perspectiva psicanalítica. Acreditamos que esse panorama introdutório (que não é nem um desvio do tema central, nem um novo recorte) tem muito a contribuir para o entendimento do que desejamos transmitir ao longo da tese.

É preciso não perder de vista que este trabalho acadêmico foi construído a partir de um esforço (e que esforço!) de problematização - e não de polarização -, ou seja, como uma tentativa de se somar a outras iniciativas que visam pensar sobre o universo digital que tem feito parte da cultura contemporânea desde os anos XX, considerando-o tanto como campo propiciador de insurgências de Eros quanto como um dos elementos que vem contribuindo para certa escassez de laços com a alteridade em nossos tempos. Nossa aposta é apontar o mundo virtual como um espaço em que coexistem tanto práticas e discursos que acentuam a fragilidade de laços com o outro nas trocas entre os internautas, quanto produções de encontros e erotismo que se servem da tecnologia como forma de reinvenção da vida. Há gozo, pulsão de morte e isolamento, mas há também iniciativas 
desejantes, invenções, novas modalidades de parceria. Trata-se, pois, de um universo coabitado pela solidão e pelos laços afetivos, fenômenos humanos que persistem na presença das máquinas, com elas, sem elas, apesar delas.

\section{1) “Apocalípticos e integrados": uma inspiração, uma referência}

O título acima nomeia a clássica obra de Umberto Eco (1965/1987) na qual o pensador italiano reuniu ensaios dedicados à abordagem das reações diante da questão da cultura de massas na era tecnológica. Neste livro entramos em contato com as reflexões do autor e de outros intelectuais de sua época, ocupados em pensar sobre a "nova situação antropológica da civilização de massa" (Eco, 1965/1987, p. 27). Eco nos serve como inspiração e referência por algumas razões. A exposição que traça a respeito da história do homem frente à máquina ${ }^{1}$, frente à tecnologia, é extremamente esclarecedora e suas colocações permanecem bastante atuais e pertinentes para pensarmos o presente. Além disso, ao falar sobre as reações - tanto dos críticos quanto da sociedade em geral - frente à cultura de massas, destaca a produção desta divisão a que o título de sua obra alude, tocando precisamente na tendência à polarização que certos fenômenos desencadeiam.

Eco, assim como nós, viveu e tentou pensar a respeito de um "mundo que uns alardeiam recusar e outros aceitam e incrementam" (idem, p. 11). Inspirandonos, portanto, na leitura deste autor, propomos transportar suas ideias de uma época à outra, ou seja, "aplicar" o que teorizou sobre a cultura de massas para o que vem sendo teorizado a respeito da cultura digital ${ }^{2}$. Com isso, intencionamos demonstrar que, ainda que os apocalípticos e os integrados sigam existindo, firmes e fortes, há meios de lidar com as novidades tecnológicas sem recair em um ou outro dos dois extremos.

\footnotetext{
1 Para um maior aprofundamento nos estudos desta relação entre os homens e as máquinas tecnológicas, sugerimos a excelente coletânea "O Homem-Máquina: a ciência manipula o corpo", organizada por Novaes (2003). Destacamos o artigo de Oliveira, no qual enfatiza a riqueza de olharmos para esta questão adotando novos paradigmas, próprios ao campo da complexidade, visando justamente não cair em determinismos ou reducionismos. O autor teoriza a respeito da diluição das antigas distinções que demarcavam as fronteiras entre natureza e cultura, sujeito e objeto, interioridade e exterioridade. Propõe que essas grandes transformações civilizacionais decorrentes dos avanços tecnológicos nos levam a viver em tempos interessantes, trazendo em seu texto um tom instigante, que convida o leitor a olhar para estas novidades como complicadas, problemáticas e, por isso mesmo, geradoras de curiosidade e interesse investigativo.

${ }^{2}$ Foi a partir de uma menção a Eco e aos "apocalípticos e integrados" feita por Gonçalves (2006) no artigo "Nós e a internet" que nasceu essa ideia.
} 
O livro de Eco se inicia de forma curiosa e instigante, com o autor criticando-se a si mesmo, ao esboçar uma espécie de pedido de desculpas ao leitor, pelo fato de sentir-se obrigado a recorrer a certos conceitos para se fazer entender. "É profundamente injusto subsumir atitudes humanas - com toda sua variedade, com todos os seus matizes (grifos nossos) - sob dois conceitos genéricos e polêmicos como "apocalíptico" e "integrado"” (Eco, 1965/1987, p. 07). Mas, afinal, que discursos e atitudes se encaixam em cada uma dessas definições? Segundo Eco, "se os apocalípticos sobrevivem confeccionando teorias sobre a decadência, os integrados raramente teorizam e assim, mais facilmente, operam, produzem, emitem as suas mensagens cotidianamente a todos os níveis. O Apocalipse é uma obsessão de discordar, a integração é a realidade concreta dos que não discordam. A imagem do Apocalipse ressalta dos textos sobre a cultura de massa; a imagem da integração emerge da leitura dos textos $d a$ cultura de massa" (p. 09).

Eco dedica seu livro aos críticos apocalípticos da cultura de massas, graças a quem pôde elaborar suas ideias. "Sem seus requisitórios, injustos, parciais, neuróticos, desesperados não teria sido possível” (p. 30). A mensagem que vai deixando clara é que a partir da observação do que fazem esses detratores, do modo extremado, generalizante, reducionista e pré-conceituoso com o qual se posicionam, é possível construir um caminho reflexivo distinto. Os apocalípticos "lideram profundamente a polêmica contra a indústria cultural" (p. 14), reduzem seu alvo de crítica a algo indiferenciado, ao invés de analisá-lo caso por caso. Eles negam-no em bloco (p. 19).

Certa vez, Eco testemunhou um deles que, ao examinar um fenômeno, o fez com desgosto e aborrecimento, parecendo tratar-se de um "vício mental" (p. 26). "Na realidade, já de partida, ele se recusou a examinar o instrumento e ensaiar-lhe as possibilidades (grifo nosso)" (p. 27).

A proposta de Eco, com a qual nos alinhamos, é a de dar lugar à variedade, às matizes, às possibilidades, sem colocar precipitadamente "a cultura de massa (ou a digital, ou qualquer outra cultura) no banco dos réus" (p. 36). Para operarmos em um mundo transformado pelo homem, nos diz o autor, devemos fazê-lo "a partir dessas condições de fato". Quer reconheçamo-lo ou não, o universo das comunicações de massa é o universo da nossa atualidade. "Ninguém foge a essas condições" (p. 11). E, se é assim, sábio é educar sobre o uso da TV 
provavelmente através da TV. Defende ainda que pensemos a civilização da TV como complemento - e não uma oposição -- a uma civilização do livro (p. 364), buscando afastar aquele fantasma de que um novo meio viria necessariamente como substituição ao antigo, produzindo o descarte do anterior.

A partir dos anos 1990, este universo das comunicações de massa que, nos anos 60, recebia a televisão como absoluta novidade, foi incrementado com a internet, vendo surgir o cyberuniverso. Sobre este, arriscamos afirmar o mesmo que Eco: trata-se de uma realidade que veio para ficar, uma nova condição com a qual precisamos nos haver. Aprenderemos sobre ela também através dela, usandoa e ao mesmo tempo contestando-a, servindo-nos dela sem contudo sermos capturados, como dirão alguns psicanalistas contemporâneos que trabalharemos a seguir. Como se fizessem eco às ideias de Eco, estes psicanalistas buscarão sustentar uma atitude de não tentar voltar ao que era antes, mas sim de "elaborar uma nova imagem de homem" (p. 16). É a defesa de uma posição não nostálgica, não saudosista, que nos parece muito mais condizente com a psicanálise.

Os apocalípticos mencionados por Eco atacavam ferozmente certos conceitos-fetiche como "indústria cultural”, já que para eles não havia nada "mais reprovável que o emparelhamento da ideia de cultura com a de indústria” (p. 12). Localizamos uma posição análoga em artigos de psicanalistas que criticam termos novos como "relação virtual” ou "laço virtual", justamente pela impossibilidade, segundo pensam, de conjugar algo tão valioso - o laço, o relacionamento afetivo com algo tão superficial e pobre como o mundo virtual. Este é mais um ponto a ser destrinchado adiante, com todas as suas complexidades. Por ora, desejamos apenas destacar o paralelo com o que nos aponta Eco a respeito do momento histórico em que viveu e formular o seguinte questionamento, do lugar de psicanalista a partir do qual escrevemos: de que nos vale essa reprovação? Da posição que escolhemos ocupar diante de um sujeito que sofre e procura ajuda, cabe esse tipo de juízo moral? Pensando assim, como poderemos escutar um jovem de 16 anos, para quem um encontro em que ele e a parceira ficam teclando lado a lado é vivenciado como um encontro amoroso? Cabe mencionar aqui uma das intervenções da personagem da terapeuta no filme francês "Encontros" (2019), do diretor Cédric Klapisch, em que diz à paciente que "ter um encontro é

\footnotetext{
${ }^{3}$ Este filme tem como temática central justamente os relacionamentos amorosos na Era da internet. Apesar de o termos achado um pouco raso vale assisti-lo.
} 
encontrar alguém que faça sentido para você". E isto, a nosso ver, pode ocorrer também através da internet.

Uma crítica interessante a respeito da cultura, segundo o autor, "não poderá e não deverá propor remédios, mas, quando muito, testemunhar sua própria divergência” (p. 17). Sendo assim, as contradições e controvérsias têm o seu lugar, são bem vindas, não precisam ser resolvidas. $O$ autor não teve a preocupação de eliminá-las nesta coletânea de ensaios e nós, assim como ele, deixamo-las aparecer, seja porque enriqueciam a pesquisa, seja porque simplesmente nos escaparam (o que, aliás, também tem um potencial de contribuição para o debate). O ponto que Eco frisa para justificar a manutenção das controvérsias naquilo que teoriza é a atualidade do tema. Em suas palavras: "Um discurso que versa sobre fenômenos tão estreitamente ligados à cotidianidade, que tão logo define um fato e seus efeitos entra em choque com o aparecimento de um novo fenômeno que parece desmentir a diagnose precedente, tem que ser, necessariamente, uma cadeia de silogismos hipotéticos com a premissa maior e menor no subjuntivo, e a conclusão no condicional” (p. 29). "Não se podem reduzir esses fenômenos a uma fórmula teórica unitária, cumpre torná-los objeto de uma pesquisa que não tema submetê-los a todas as verificações" (idem). Afirma, portanto, que a natureza "condicional" desse tipo de pesquisas dedicadas a temas contemporâneos leva a crer que sejam passíveis de uma contínua reformulação. No caso de nossa pesquisa, a natureza "condicional" tem a ver com isso, com a atualidade do tema, mas não só. Essa contínua reformulação também se faz necessária por que lidamos com sujeitos singulares, porque sabemos que cada caso é um caso (o tópico 1.4 a seguir será dedicado a isso).

Ainda sobre o crítico da cultura e seu dever de pesquisa, Eco (1965/1987) alerta para o fato de que definições em termos gerais correm o risco de contribuir para generalizações. Como um cidadão de uma multidão que ainda não conhece completamente porque vive numa civilização de mutantes, terá que retornar, de cada vez, aos objetos e seus consumidores, como se se prestasse a descobrir algo inédito (p. 26). Esse enaltecimento de uma postura que não encampa a nostalgia, que não fica presa em referência ao velho, mas que propõe uma atitude de “indagação construtiva” (p. 35) é um dos grandes motivos de tomarmos essa obra de Umberto Eco como fonte de inspiração. Seu pensamento embasa nossa visão 
de que, em relação à internet, o advento do novo não destrói por completo hábitos antigos.

\section{2) Erotismo e escassez na era da internet: o debate entre Pitliuk e Birman}

Em 1997, ano em que a internet ainda não era acessível à população em geral, Joel Birman escreveu um artigo sobre o filme "Denise está chamando" (1995), do diretor Hal Salwen. Três anos mais tarde, a psicanalista Lia Pitliuk resgatou a análise de Birman a respeito do filme e da sociedade contemporânea para pensar nas possíveis interações entre informática e subjetivações. O objetivo de Pitliuk ao reapresentar, a seu modo, as ideias de Birman era denunciar o tom de polarização que marca o artigo do autor, para, em seguida, propor uma recepção às tecnologias da comunicação livre de um a priori negativo.

A ideia de dedicarmos essa seção ao debate - via artigos - travado entre estes autores pioneiros na reflexão sobre psicanálise e novas tecnologias da comunicação é apresentar através desse exemplo de excelente qualidade epistêmica a discussão acerca da tendência à polarização que é uma marca da literatura produzida até aqui a respeito de nossa temática de pesquisa. Ainda que sejam textos de 1997 e 2000 e que, para o assunto "redes virtuais e laços sociais" o transcurso de duas décadas tenha trazido transformações assombrosas, as reflexões ali desenvolvidas são extremamente atuais e úteis. Para nós, tanto Birman quanto Pitliuk se lançaram em um exercício de indagações construtivas (tal como propôs Eco), produzindo, em ambos os casos, argumentos bastante fecundos. A seu modo cada um traz uma valorosa contribuição para os psicanalistas às voltas com as novas tecnologias de comunicação e seus efeitos subjetivos. Além de apresentarmos o debate em questão, ousaremos nos inserir como um terceiro debatedor em alguns pontos que interpretamos como controversos.

Os efeitos desse debate obtiveram para nós uma função de verdadeira aprendizagem pela força transformadora que entrar em contato com esses dois textos lado a lado operou no presente processo de pesquisa. Havíamos lido a análise de Birman a respeito de "Denise" e, só depois ${ }^{4}$, conhecemos o trabalho de

\footnotetext{
${ }^{4}$ Agradecemos à professora Daniela Romão-Dias por esta sugestão de leitura, durante sua participação na Banca de Qualificação.
} 
Pitliuk. Reler o primeiro à luz do segundo nos ajudou a nos situarmos neste campo de estudos. Os estudos subsequentes da pesquisa passaram a tomar essa 'dobradinha' como uma espécie de chave de leitura. A cada nova abordagem, a cada autor descoberto, voltávamos a esse ponto para lapidar nossas próprias reflexões e conclusões parciais. Do que ficou para nós, cada um deles aborda com densidade a presença de uma coexistência entre erotismo e escassez (a qual sinalizei no título deste tópico) nesse mundo invadido por linhas telefônicas e computadores.

Vamos aos textos propriamente ditos. Com um título que é em si mesmo rico em significações Birman abre seu trabalho de elaboração a respeito desse belo e instigante filme que é "Denise está chamando": "Entre o gozo cibernético e a intensidade ainda possível: entre a lógica maquínica e a lógica da pulsação". Para nós que estamos interessados em pensar sobre solidão e laço em tempos de conectividade, lembrar-se desse filme através de Birman foi um verdadeiro achado. As descrições das relações que passam a ser estabelecidas através desses novos meios alimentam as reflexões sobre os laços que construímos uns com os outros na contemporaneidade. Dessa forma, ajudam a pensar sobre as definições de isolamento, de estar junto, de amizade, que precisam incluir novos aspectos para serem reescritas e atualizadas nesse novo universo. A seguir, transcrevemos duas destas formulações do autor que valem a leitura: "A narrativa trata de um amontoado de personagens ligados entre si por linhas de telefone. Apesar de serem amigos, supostamente, os telefonemas são as únicas formas efetivas que os unem. Cada um dos personagens vive de modo inteiramente isolado, restrito no espaço de seu apartamento, sem qualquer forma de relação com os outros que não sejam os telefonemas" (Birman, 1997, p. 213); "Além da rede de relações pelo telefone e pelo computador, que são operadores cruciais desse universo medíocre, nada os aproxima da existência em comum. Enfim, a mediocridade de valores, presentes nas suas existências é o que os unifica no vazio de suas vidas, e o que os impede de estar juntos, ao mesmo tempo. É essa identidade entre eles que os faz acreditar que sejam amigos!” (p. 215).

Segundo nossa leitura, o texto pode ser dividido em dois momentos: no primeiro o autor tece sua crítica bastante contundente a respeito das novas tecnologias de comunicação. Diante daquele contexto em que ainda nem existiam a internet, as salas de bate papo virtuais, as redes sociais, os aplicativos de 
conversa ou os de encontro, denuncia a precariedade dos laços de amizade e de amor, apresentando uma visão negativa, pessimista, aproximando-se dos apocalípticos citados por Umberto Eco. Birman expressa sua preocupação utilizando expressões como aridez afetiva; deserto como cenário fundamental de suas vidas; desafecção total que está em marcha; o corpo não sente mais nada em sua maquinização; impossibilidade de qualquer encontro; monotonia; vazio absoluto; pobreza existencial dos personagens; impressionante mediocridade existencial dessas figuras humanas; individualidades transformadas em verdadeiros autômatos, sem qualquer traço de pulsação.

Além dessas há outras várias colocações do autor que testemunham esse tom fatalista: tal obra lhe apresentou com muita contundência "a tragédia da atualidade" (p. 213); "Até mesmo uma suposta trepada se realiza pelo telefone! Orgasmo por telefonia?” (p. 214); “orgasmo cibernético!” (p. 224); “O esboço dramatúrgico que Salwen traça e pincela sobre a pós-modernidade é terrível". "O sujeito esvazia assim as relações com os outros e consigo mesmo" (p. 226); “Automatismos engendrados pela tecnologia avançada de comunicação à distância" (p. 217); "as avançadas tecnologias telefônica e cibernética afastam decisivamente as pessoas da vida, fazendo-as perder o rosto, a memória, a afetação e até mesmo a riqueza da linguagem” (p. 225). A partir de uma cena do filme na qual ocorre um acidente de automóvel fatal em que "o telefone entrou pelo crânio, esmigalhando o cérebro e desfigurando monstruosamente o rosto" ( $p$. 216), Birman afirma que "a tecnologia é o instrumento da morte" (p. 215).

Através de todos esses exemplos evidencia-se a faceta apocalíptica do artigo, a qual será alvo das críticas de Pitliuk. De fato, a mensagem final que nos é transmitida enfatiza que as mudanças são para pior, que sofremos fortes perdas e que há um empobrecimento das subjetividades contemporâneas, juntamente à precarização da alteridade. As invenções tecnológicas aprisionam e desvitalizam, contatos mediados substituem os contatos imediatos. "Foda-se o outro, então" (p. 229), é o que conclui Birman.

Porém, nesse mesmo contexto vive Denise, a personagem que empresta seu nome ao filme. Com ela, vemos que ainda que haja uma nefasta transformação em curso, o sujeito não necessariamente sucumbe a isso. Essa mulher que deseja e insiste encena na trama uma exceção e simboliza a possibilidade de que, na sociedade informatizada, existam "Denises". E é a isso 
que Birman se dedica naquele que a nós se apresentou como o segundo momento de seu texto. Ali, ao focar nessa peculiar personagem, apresenta a possibilidade de haver desejo e pulsação em meio ao uso da tecnologia para a comunicação. Nas palavras do autor: "duas lógicas permeiam a tessitura ética da pós-modernidade: a lógica pulsante de Denise existe ao lado da lógica maquínica das demais personagens" (grifo nosso, p. 225). Assim, no interior desse mesmo artigo que pode facilmente ser usado como base forte para posturas contra as tecnologias, encontramos argumentos que apresentam uma saída erótica no uso das mesmas.

A partir de "Denise" Birman parece traçar uma espécie de manual de sobrevivência em meio ao "deserto tecnológico da pós-modernidade" (Birman, 1997, p. 225), apostando na pulsação e no desejo, na "busca apaziguada do contato quente com o outro" (idem, p. 221). Tal como um resíduo, Denise contrasta, "Denise calls up, porque para ela é vital que possa falar e ser afetada diretamente pelos outros" (idem). Ela ilustra que "às vezes, a tecnologia pode também (grifo nosso) possibilitar o imprevisível. Mas apenas quando ela é utilizada por um sujeito que não suporta mais conviver com esse vazio existencial e com a monotonia entediante desse universo mediocrizado. Somente quando alguém ainda pulsa e deseja ser afetada, a tecnologia pode se inscrever num outro registro" (p. 221). Extraímos daí uma das ideias a que nos levou nossa pesquisa: podemos nos manter quentes e vitais mesmo fazendo uso do celular ou das redes sociais. "O pesado maquinismo tecnológico do isolamento absoluto" (Birman, 1997, p. 232) é poderoso, mas não incide da mesma forma em todo mundo. Seguimos capazes de poder resistir, de prestar atenção nos efeitos que geram em nós. Há diferentes registros em que a tecnologia pode se inscrever, não sendo o registro da mortificação e da escassez de Eros o único possível.

Entendemos, portanto, que Birman não está sendo dicotômico em sua análise das tecnologias, ou seja, não interpretamos sua posição neste artigo como exemplo inequívoco de polarização. "A pulsação ainda persiste, apesar dos pesares", conclui o autor. Quando na última página do artigo convida seus leitores - em "Façam suas apostas!" - a um trabalho constante de pensamento e discursividade, parece estar propondo que há saídas interessantes para o cenário terrível que ele mesmo ajuda a traçar. Seu posicionamento dá abertura para que concebamos as máquinas não como vilões absolutos. Consideramos ainda que as 
apostas vislumbradas pelo autor admitam a possibilidade de que alguém possa manter-se desejante incluindo em seu circuito pulsional objetos tecnológicos.

É hora de conhecermos o texto $^{5}$ de Lia Pitliuk (2000), onde se dá propriamente o debate entre os autores ao qual nos referimos nessa seção. Visando ilustrar a afirmação que faz, de que "a grande maioria das publicações e debates em psicanálise tem situado a tecnologização da vida contemporânea como uma grande inimiga da saúde psíquica" apresenta a argumentação de Birman no artigo que acabamos de trabalhar. Parte de um questionamento interessante para se aproximar do tema e para mapear as produções do campo: "o que vem se produzindo no encontro entre homem, psicanálise e informática?". O artigo de Birman serve de certa forma como uma resposta a essa pergunta. Partindo de diversas passagens do autor (tais como as que citamos há pouco) localiza uma aproximação feita por ele entre mundo tecnologizado e desumanização. Destaca também que entre as duas lógicas propostas por ele - a maquínica e a pulsional há uma divisão, uma oposição. Logo a seguir, apresenta aquela que para nós é a mensagem principal trazida por esta psicanalista em seu texto: a necessidade de “discutirmos - e muito - se essa polarização (grifo nosso) entre pulsional e antipulsional pode ser equacionada à presença maior ou menor das máquinas em nossa vida, como aparece neste e em tantos outros textos. Se essa aproximação entre tecnologização e o polo anti-vida se justifica, e em que medida é efeito de um preconceito".

Pitliuk (2000) opta então por recorrer a sua clínica, em busca de "histórias muito intensas de pessoas junto aos computadores" (idem), a fim de exemplificar que esta oposição muitas vezes não se sustenta. Apresenta o caso de Silvia, moça para quem "o recurso das mediações da Internet - e, especialmente, dessa relação humana mediada por computador - teve um efeito mutativo de grandes proporções". A vinheta apresenta elementos importantes que introduzem uma problematização fundamental segundo a autora, com quem estamos absolutamente de acordo neste ponto. A questão que lhe parece estar no âmago do tema subjetivações e informática é o esforço de não aderir a um único ponto de vista, aquele que frequentemente pensa haver algum grau de "fuga da realidade", "submissão às normas narcísicas da cultura”, “incapacidade de suportar a

\footnotetext{
${ }^{5} \mathrm{O}$ texto a que tivemos acesso é uma transcrição de uma conferência da autora e por essa razão não estamos incluindo as páginas das citações.
} 
alteridade", "controle onipotente". Sem negar que obviamente são elementos presentes nesse processo, sem excluí-los, portanto, da cena, Pitliuk nos convoca a discutirmos "se esses são palavrões ou se podem ser pensados também em sua face constitutiva, ou reconstitutiva". A ideia é considerar que para alguns sujeitos e/ou em algumas situações e/ou fases específicas de nossas vidas o recurso à mediação dos computadores nos relacionamentos é o que permite "se relacionar, trabalhar, viver, com alegria".

A conclusão a que chega em sua conferência / texto é esclarecedora. A partir de Pitliuk, de outros autores e também de nossas observações na clínica e na cultura em geral, passamos a sustentar essa afirmativa, assim enunciada pela autora em questão: “o que é mortífero e desertificador é a totalização”. Quando a relação com a tecnologia transforma-se em totalização, há perigos. Esta sim seria uma vivência desertificadora e mortífera ${ }^{6}$. E aqui, cabe pensarmos tanto nas totalizações digitais - que se fazem absolutamente presentes em nossos dias através dos adolescentes siderados em seus games, dos japoneses com suas namoradas virtuais, das lanhouses coreanas que oferecem fraldas a adultos quanto em todas as demais, como as compulsões alimentares e as toxicomanias.

Prosseguindo em sua argumentação e dialogando com as críticas de Birman aos personagens do filme para além de Denise, Pitliuk (2000) considera preconceito ou ingenuidade reduzir os encontros somente aos que acontecem entre pessoas no face-a-face, ou imaginar que esse tipo de encontro é mais "verdadeiro" que os on-line. Propõe olharmos para "os novos mundos cibernéticos" "nem como agentes do mal, nem como a panaceia do paraíso, mas como espaços de jogo e experimentação, com seus riscos (que não são nada pequenos) e suas possibilidades de criação". Sugere que caminhemos muito devagar ao situar a informática como campo de alienação e anestesia e que mantenhamos a escuta flutuante, uma posição de abertura e de suspensão de preconceitos e ideologias. Como psicanalistas não devemos contribuir para execrar novos elementos da cultura como imprestáveis. "É importante admitirmos que nessas novas formas de

\footnotetext{
${ }^{6}$ Cabe aqui um brevíssimo comentário sobre a relação de dois de meus pacientes com as séries disponibilizadas pelo Netflix: Para a jovem de 30 anos que se enclausura para fazer "maratonas de séries", o hábito é sentido, a posteriori, como um excesso destrutivo, que a retira do laço social. Já para o idoso deprimido e com dificuldade de locomoção, apaixonado por cinema e por História, as séries são vivificantes, fonte de prazer, de aprendizado e de assunto com seus conhecidos quando eventualmente sai.
} 
viver e experimentar que tanto estranhamos também (grifo nosso) pode estar uma luta guerreira contra a alienação e a anestesia".

Para finalizar esse debate entre ideias e autores que por si só tem muito a ensinar, transcrevemos uma última colocação de Birman. Ao referir-se à tecnologia, afirma que ela "tudo permite $e$ tudo impossibilita" (grifo nosso. p. 214). A nós interessa especialmente destacar esse "e", que simboliza a coexistência, a complexidade, as misturas. Quando pensamos a respeito da internet e de seus usos por sujeitos singulares, a adoção de um pensamento binário para analisar os fatos do mundo, do "ou isso ou aquilo", não ajuda. Essa lógica reduz as possibilidades, não alcança a complexidade dos fenômenos em questão. Diferentemente de Cecília Meirelles em seu belo poema citado para abrir este capítulo, aqui, ao invés de "ou isto ou aquilo", de nos ocuparmos em saber qual é melhor, interessa-nos pensar sobre isso "e" aquilo, ou seja, refletir não tanto sobre os efeitos positivos e negativos das tecnologias de comunicação, mas, sobretudo, sobre os efeitos transformadores dessa novidade.

Reafirmamos então um de nossos maiores esforços na confecção desta tese, o de podermos nos situar entre os estudos (ainda raros) não polarizados sobre internet e subjetividades. Desejamos manter vivas as controvérsias, buscando trilhar um caminho reflexivo que contemple o prisma da tensão entre as diferentes perspectivas. Para isso, apresentaremos as polêmicas e exploraremos as discussões que delas emanam, procurando não aderir instantaneamente a afirmações simplórias como "a tecnologia aproximou os distantes e distanciou os próximos" nem tampouco a questionamentos ainda muito comuns tanto nos livros quanto nas ruas, tais como o que exporemos a seguir: "Estamos em plena era da tecnologia. Nunca a comunicação foi tão fácil e tão abrangente. Mas estamos nos comunicando mais e melhor? Nunca os contatos sociais se tornaram tão múltiplos e tão diversos. Mas as amizades se multiplicaram por conta disso?" (Cavalcanti, 2014, p. xiv).

$\mathrm{Na}$ contramão de um coro entoado por grande parte da sociedade e por alguns intelectuais que formulam perguntas como: "Mundo digital: criação ou alienação?7 ; a internet afasta ou aproxima as pessoas? Une ou separa? Isola ou

\footnotetext{
${ }^{7}$ Essa pergunta nomeou uma das mesas de trabalho do "Simpósio Internacional de corpo, imagem e tecnologia" que ocorreu na PUC-Rio, sob a organização do departamento de Psicologia em agosto de 2017.
} 
conecta? Ajuda ou atrapalha os relacionamentos? A vida está melhor ou pior com ela? Como pode acontecer um encontro ao se excluir a mais extensa zona erógena do corpo?" caminharemos lado a lado àqueles que se interessam pelo fenômeno questionando-o de outro modo, como o exemplificado a seguir: "O que acontece quando faltam o corpo a corpo, a carícia e o aperto de mãos, o encontro de um olhar furtivo, a percepção do rubor ou a mudança sutil do tom da voz do interlocutor?" (Gueller, 2017, p. 64) (grifo nosso).

Isso porque, concordamos com Sibilia (2015) quando, apoiada em Peter Sloterdijk (2001), afirma que "convém tomar precauções diante da histeria antitecnológica", como ele a denominou, pois, nesse contexto de fortes transformações, ela expressaria "o ressentimento da bivalência caduca contra uma polivalência que não pode compreender" (Sloterdijk, 2001 apud Sibilia, 2015, p. 242). Encontramos no filósofo americano Jordan Shapiro discurso análogo, do qual destacamos a interessante proposta que faz a pais e educadores a respeito do tema 'crianças e novas tecnologias': "parem de perguntar se isso é bom ou não e passem a pesquisar o que importa: há formas melhores de se usar as telas?" (Jornal O Globo, 05 de janeiro de 2020, p. 40).

Nosso foco, portanto, é investigar as profundas consequências e as novas dificuldades e conflitos gerados, o que faremos através do esboço de algumas hipóteses e da formulação de novas perguntas. Partindo do pressuposto de que a internet ocasionou uma influência transformadora, quais as novidades sentidas no campo dos relacionamentos? A partir do que aprendemos com Birman, com Pitliuk e com a troca entre os dois, indagamos: quantas "Denises" há hoje? Como podemos inserir os computadores e smartphones em nossas vidas sem perder a vitalidade e o desejo pulsátil dessa personagem, sem nos transformarmos em autômatos capturados pela totalização digital? O recurso à clínica adotado por Pitliuk em sua visada de escapar da polarização é, sem dúvida, uma proposta que torna a psicanálise um campo ímpar para mantermo-nos nessa modalidade de reflexão. Assim como Denise, a paciente Silvia ensina a nós psicanalistas sobre os perigos de interpretações generalizantes, rápidas, moralistas. Tais sujeitos, assim como todos os outros, desafiam os psicanalistas dotados de seus antigos saberes e acostumados aos seus habituais fazeres a revê-los, confrontá-los, fortalecê-los, adaptá-los, a enfim, manter viva a psicanálise nesse universo em mutação. 


\section{3) A novidade internet e suas diferentes recepções}

A internet é uma maravilha, a internet é um horror. Não sei como a humanidade pôde viver tanto tempo sem o e-mail e o Google, não sei o que será da nossa privacidade e da nossa sanidade quando só soubermos conviver nesse ciberuniverso assustador.

Sarah Westphal da Silva, Quase (texto atribuído a Luis F. Veríssimo) em Cora Rónai, Caiu na Rede

É a melhor época para ser curioso e a melhor para ser um idiota.

Weinberger, Repensando o conhecimento na era da internet

O diálogo Fedro de Platão é mencionado por diversos dos autores ${ }^{8}$ estudados que, em suas reflexões sobre a internet, exploram a polêmica acerca de seu potencial de melhorar ou piorar certos aspectos de nossas vidas. Diante de tantas referências ao filósofo ficamos curiosos e decidimos pesquisar mais a fundo esta fonte. Através do artigo "O Fedro e a escrita" (Pinheiro, 2008) conhecemos o mito de Theuth (ou Tot) inventado por Platão para abordar a discussão existente em sua época entre os oradores e os logográficos. A questão em debate pode ser assim resumida: o advento da escrita melhorou ou piorou o problema do esquecimento? Para melhor compreendermos os argumentos em jogo (e, em seguida, podermos utilizar essa referência para pensar a internet e suas consequências para a comunicação entre as pessoas) transcrevemos abaixo partes do mito deste Deus inventor egípcio, mito fundador de uma certa crítica à escrita:

(...) quando chegou a vez da escrita, Theuth disse "Essa invenção, ó rei, tornará os egípcios mais sábios e promoverá sua memória, pois isso que descobri é um elixir (phármakon) para a memória e para a sabedoria". Mas Thamus respondeu: "ó muito inventivo Theuth, alguns têm a habilidade de descobrir as artes, outros têm a habilidade de saber qual o beneficio e maleficio para aqueles que as utilizam. E tu, que és o pai da escrita, foste conduzido pela tua afeição a atribuirlhe um poder oposto ao que realmente possui. Pois isso vai produzir esquecimento na mente daqueles que a aprendem: eles não vão exercitar a memória por causa da sua confiança na escrita, que é algo exterior, provinda de caracteres alheios, e não vão eles mesmos

\footnotetext{
${ }^{8}$ Audibert (2008), Laurent (2017), Leduc (2016a), Dessal (2017b).
} 
praticar a lembrança interior, por si mesmos. Tu inventaste um elixir da lembrança, e não da memória, e tu ofereces aos teus discípulos uma aparência de sabedoria, não verdadeira sabedoria, pois se tornarão muito informados, sem instrução, e terão, assim, a aparência de que sabem de várias coisas quando na verdade são, na maior parte, ignorantes e dificeis de conviver, já que não são sábios, mas apenas aparentam ser" (Fedro 274c-275c apud Pinheiro, 2008, p. 73).

O termo phármakon $^{9}$ utilizado por Platão merece destaque, pela duplicidade que comporta: serve para classificar algo tanto como um remédio quanto como um veneno. Dá notícias, portanto, de que uma mesma coisa pode servir para curar / melhorar ou para piorar / matar, dependendo da quantidade desta coisa que é usada por alguém. Esse caráter de ser um phármakon, tal como denunciou Platão em relação à escrita, pode também ser atribuído à internetmemória, tal como propõe Laurent (2017): "É um remédio contra o esquecimento e um veneno. A internet nos fará esquecer coisas essenciais. Elas retornarão de outra maneira" (Laurent, 2017, p. 15).

Distanciando-nos do problema específico do esquecimento / memória, mas aproveitando a riqueza do termo phármakon, propomos o seguinte desdobramento: lançar mão deste remédio-veneno para pensar o uso da internet para a comunicação, ou seja, para pensar em seu papel nos laços que fazemos uns com os outros. Se o que diferencia o efeito maléfico ou benéfico é a quantidade, talvez possamos relacionar este ponto àquilo que Pitliuk (2000) enxerga em relação à totalização. Se assim for, para os que usam a rede em excesso, esta seria mortífera, mas, para aqueles que a usam com moderação, ela traria melhorias no viver. Por ora ficamos apenas com esse apontamento, para, nos próximos tópicos, abrir essa questão, explorando suas complexidades.

A discussão transmitida através do mito de Theuth nos inspirou a esboçar mais um paralelo com nosso tema de pesquisa. O inventor da escrita tentava defendê-la como remédio para o esquecimento. E foi atacado justamente nisso, sendo acusado de que sua invenção acabaria tendo o efeito oposto ao esperado. Com relação à internet como meio de conexão entre as pessoas, talvez esteja ocorrendo o mesmo: aquilo que inicialmente poderia servir para unir as pessoas

\footnotetext{
${ }^{9}$ Para um maior aprofundamento sobre este termo, ver DERRIDA, La pharmacie de Platon.
} 
pode ter o efeito contrário, de gerar mais conflitos e isolamento. Voltaremos a essa discussão em outros momentos da tese.

Recorrer ao Fedro de Platão pareceu-nos pertinente por um motivo adicional: chamou-nos a atenção o fato do mito de Theuth abordar diferentes reações possíveis a algo novo que se instala em uma cultura. Partiremos dele, então, como uma introdução para falar da novidade que é o foco desta tese: a internet. Sem nos perdermos em um histórico abrangente sobre seu surgimento (sobre o qual já existe uma extensa e qualificada bibliografia), elencaremos a seguir as reações mais expressivas à rede e seus impactos, tendo como objetivo apresentar com mais detalhes o terreno frente ao qual o debate entre Pitliuk e Birman ganha potência.

Ao longo da história da humanidade pôde-se observar que a cada grande virada tendem a ocorrer manifestações catastrofistas, o que, com a internet, não seria diferente. O momento inicial de difusão dessas novas tecnologias foi marcado por um enorme susto, relacionado ao seu ineditismo e ao seu grande poder de subversão. As possibilidades inauguradas pela internet eram surpreendentes, ilimitadas, atraentes produzindo, de um lado, surpresa e prazer de milhões de apaixonados e de outro espanto, horror e até revolta de milhares de decepcionados (Nicolaci-da-Costa, 2006). "Frente à novidade encontram-se sentimentos de exaltação coexistindo com a mais profunda inquietação e até mesmo um certo pânico", esclarece Gonçalves (2006, p. 229). O novo gera um misto de fascínio e horror, é recebido com otimismo ou pessimismo, sendo sacralizado ou demonizado. A classificação da internet como "milagre e também pesadelo" (Lazarus-Matet, 2017, p. 53) ilustra bem o clima de euforia e pânico moral que se instaurou em relação a seus impactos.

Mas que argumentos os entusiastas e detratores sustentam para embasar suas posturas em relação à rede? Os que celebram a web enaltecem o fato de ser um espaço para trabalhar produtivamente sua identidade, para dialogar, para aprender, para se divertir, para interagir, ou seja, ampliar o universo de conhecimento, de lazer, de relacionamentos, produzindo, de diversas maneiras, uma intensificação no viver.

Os que se mostram desagradados ou mesmo os que chegam a rejeitá-la (pois consideram que a internet é o que de pior existe) enfatizam e denunciam os efeitos nocivos da hiperconectividade. Para estes, a navegação online gera apenas 
relacionamentos frágeis e passageiros, visto que os contatos com o outro são pobres e alienantes e prejudicam o tempo de qualidade que poderia estar sendo vivido em família. A rede produz ou aumenta a solidão, pode levar à depressão, afasta os jovens do convívio e dos estudos, leva a separações conjugais. Soma-se ainda, a essa lista, uma série extensa de perigos do mundo on-line ${ }^{10}$, tais como: a internet entorpece com entretenimento barato, com promessas de oportunidade, escapismo, reinvenção de identidade e refúgio do tédio da vida. Há ali uma exibição de intimidades em detrimento da privacidade, a exposição precoce ao cybersexo, o aumento do risco de ser vítima de pedofilia, além de uma excitação contínua por estímulos infinitos, que nos deixa permanentemente "ligados" e resulta em aspectos mortificantes da vida humana.

Encerrando os aspectos negativos por nós encontrados durante a pesquisa temos o destaque dado à web como lugar da obscenidade vergonhosa pela difusão em massa da pornografia; um lugar que encoraja o retorno de radicalismos religiosos e todas as outras modalidades de raiva dada a impunidade que o anonimato propicia; lugar de relativismos políticos e dissolução das verdades, justaposição de fatos, mentiras e rumores de todo tipo. A preocupação com o uso exagerado é quase unânime, pois este pode causar distúrbios no sono, aumento da ansiedade, acarretar problemas na interação social, e, em alguns casos, levar à dependência ou vício. Alvo privilegiado de críticas, as redes sociais são vistas como novo ópio do povo, como uma armadilha que contribui para o surgimento de frustrações, oriundas de comparações injustas por elas incitadas. $\mathrm{O}$ depoimento de uma jovem de 18 anos ilustra bem esse ponto: "Em momentos de vulnerabilidade, o excesso de "felicidade" presente no Instagram pode fazer mal".

Com a enumeração destas reações polarizadas à rede juntamente aos argumentos que fortalecem um ou outro ponto de vista, acreditamos ter ficado mais claro o desafio em que nos lançamos. Visando evitar aderir a qualquer uma dessas tendências, fomos à procura de autores que se posicionassem de uma maneira mais multifacetada em relação ao fenômeno internet e, felizmente, os encontramos. Podemos dizer que eles já existem em um bom número e que trazem argumentos sólidos e muito convidativos aos que querem refletir cuidadosamente, distanciando-se de conclusões precipitadas.

\footnotetext{
${ }^{10}$ Sobre esse aspecto em especial recomendamos o filme "Homens, mulheres e filhos", direção de Jason Reitman (2014). O livro que o inspirou, de mesmo nome, é igualmente interessante.
} 
Um aspecto trabalhado por alguns desses autores se destacou em nossas leituras, tanto porque foi abordado por uma gama de pensadores, quanto pelo fato de que este aspecto estabelece um ponto de partida que, de saída, produz um afastamento de posições generalizantes. Em palestra recente Sibilia (2019) o apresentou de forma clara e sucinta: as tecnologias não são boas ou más. Além disso, não são neutras, são históricas. Eco (1965/1987) abordara tal questão em seus "Apontamentos sobre a televisão", mais precisamente na conclusão a que chegou sobre a TV naquela época: "a TV pareceu-nos algo como a energia nuclear, e, como a energia nuclear, só pode ter suas finalidades estabelecidas com base em claras decisões culturais e morais" (Eco, 1965/1987, p. 363). McLuhan, outro importante teórico dos anos 60 , propõe uma perspectiva a partir da qual a pergunta sobre o valor de um meio de comunicação, sobre seu valor moral - se é bom, se é ruim - fica descartada, pois para ele o que importa é o que fazemos com este meio. Para escancarar o sentido do que está propondo dirá, com relação às máquinas, que elas são capazes de produzir armas ou cornflakes (McLuhan, 1968, p. 26 apud Leduc, 2017, p. 08).

Dentre os autores da atualidade que se dedicaram a essa questão, "para que servem as máquinas?", poderíamos, a grosso modo, dizer, selecionamos três psicanalistas de orientação lacaniana, todos interessados em pensar especificamente sobre essa questão aplicada ao universo digital. Em entrevista ao jornal francês Le point Miller (2011) é confrontado com a seguinte pergunta: “Devemos nos alegrar com o poder da ciência?” Responde que nós nos alegramos $e$ tememos seus efeitos ao mesmo tempo (grifo nosso). A ciência é um frenesi, é impossível cortá-lo, nenhuma nostalgia vai impedir isso, diz ele. "A mudança é certa. Para melhor ou para pior? Ça selon ${ }^{11 "}$ (Miller, 2011). Anos mais tarde, Laurent (2017) reitera essa mensagem de Miller através dessa afirmativa: "Que a política e o discurso do mestre foram afetados pela internet, nós o observamos, para o bem e para o mal" (Laurent, 2017, p.13). Dessal (2017b) alinha-se à mesma perspectiva, o que pode ser percebido nesta passagem de um de seus artigos: "Do mesmo modo que um simples pau pode servir para alcançar frutas em uma árvore, cavar um buraco, caçar um animal ou romper o crânio de um semelhante, a técnica é e seguirá sendo parte da condição humana, servindo a finalidades

\footnotetext{
11 Expressão que em português significa "isso depende".
} 
distintas, algumas a favor do desejo de vida, outras em benefício de interesses letais" (Dessal, 2017b, p. 14). Complementa a mensagem que visa transmitir afirmando que "a técnica não possui uma propriedade demoníaca intrínseca" (idem, p. 3).

Tendo esmiuçado nosso posicionamento frente ao campo de estudos que escolhemos para pesquisar, é hora de enunciarmos, afirmativamente, as posturas que nos atraíram. Começamos com Almeida e Eugenio (2006) que propõem que tenhamos "menos perplexidade e susto diante de um espírito de época a cada dia mais desafiador e mais curiosidade e reencantamento" (Almeida e Eugenio, 2006, p. 78). O elogio de Ferrer (2015) ao trabalho de Sibilia no livro "O homem pósorgânico" também nos serve de referência: "Sem rejeições apressadas nem entusiasmos incautos, mas com ânimo de elucidar e desentranhar". Da própria autora, destacamos algumas mensagens transmitidas neste livro: "praticar o saudável exercício de estranhamento, a fim de ensaiar novas refutações ou provocações" (p. 18) e formular boas perguntas, como estas: "As potências da vida se enriquecem nesses movimentos ou elas são fatalmente cerceadas pelos novos arranjos das redes de poder e saber? Abrem-se outras opções de resistência e de criação ou fecham-se todos os caminhos?" (Sibilia, 2015, p. 241).

Enfim, se, por um lado, há fortes indícios na cultura atual para que tendamos ao catastrofismo, ou seja, ao pensamento de que a internet trouxe mais malefícios do que benefícios para a comunicação entre os homens, por outro, parece-nos mais rico que busquemos nos separar dessa tendência, rumo à reflexão e à problematização. Nesse ponto concordamos com Sherry Turkle, quando diz que não se trata de defender ou atacar. O primeiro passo é pensar que se trata de uma experiência diferente. Está na hora de sermos curiosos a respeito dessa experiência e não somente "entusiastas" ou "críticos" (Turkle, 2017b, p. 139). Para a psicanalista francesa Caroline Leduc, as mudanças tecnológicas são acompanhadas por uma tensão moral que diz respeito a uma perda, já que implicam uma renúncia a um modo de gozo precedente. Ilustra sua posição embasando-se no diálogo Fedro de Platão e citando os amantes do vinil ou os leitores “de papel” (Leduc, 2016b, p. 05). Considera exagerada essa tensão, esse frisson, essa irritação moral. Na geração dela isso existia em relação à televisão, a quem era atribuído o risco de que não mais se escreveria, o que de fato não aconteceu. Referindo-se diretamente à internet, o psicanalista brasileiro Iannini 
(2019) alude às mudanças e ao grau de indefinição que ainda persiste com relação ao seu alcance. Em suas palavras: "As redes sociais, as fake news, as selfies enlaçam os sujeitos de uma forma cujos efeitos ainda não sabemos medir" (Iannini, 2019, p. 28).

Desse modo, mantemos nosso propósito de pensar, nessa tese, de que maneiras, em meio à guerra contra a tecnologia, nós psicanalistas podemos atuar de forma desarmada, dispostos a contribuir com as reflexões de nossa época. E, se for para pensar em armas, quais seriam as nossas? A partir das frequentes e complexas questões que nos são endereçadas por aqueles que sofrem e nos procuram, quanto podemos aprender sobre esse universo digital? Oferecer nossa escuta e sustentar um 'não saber' - tanto nosso quanto do paciente - que põe o sujeito em trabalho psíquico são atos preciosos que certamente ainda nos cabem e geram efeitos surpreendentes. Como nos ensina Lima (2017), "conhecer essa ambiência (virtual), destituído de pré-conceitos, é fundamental para aquele que pretende se aproximar dos jovens hoje" (Lima, 2017, p. 83).

\section{4) As tecnologias digitais e seus múltiplos usos}

A internet não é uma só e os internautas não são todos iguais. Existem sujeitos e existem usos de internet.

Margarita Álvarez, Sobre os laços na web

Neste capítulo de abertura, pretendemos demarcar que esta tese se insere no grupo de estudos psicanalíticos que desejam pensar a psicanálise em sua dimensão ética e política. Sendo assim, é fundamental explorarmos quais os desafios que a psicanálise encontra neste contexto que nos dispusemos a estudar. Diante dos sujeitos solitários e/ou enlaçados da Era digital, o que temos a dizer?

Em continuidade às ideias apresentadas a partir de Eco, Birman e Pitliuk frisamos os referenciais que nos parecem mais próprios à psicanálise enquanto instrumento de leitura dos fenômenos do mundo e também enquanto dispositivo clínico, de tratamento de sujeitos em sofrimento psíquico. Acreditamos ser prejudicial às reflexões a respeito da internet divisões em polos separados e estanques, de todas as ordens. Parece-nos empobrecedor, como já dito, e pouco condizente com a realidade em que vivemos nos anos 2020 afirmar ser melhor ou 
pior lançarmos mão da internet em nossos relacionamentos interpessoais, assim como supor de antemão que certo uso da web é bom ou ruim. Estamos de acordo com Dessal (2018) quando afirma que "a demonização da técnica pode chegar a ser tão improdutiva e absurda quanto a sua idealização" (Dessal, 2018, p. 07). É deste mesmo autor o livro recém-lançado em 2019, "Inconsciente 3.0", do qual destacamos o subtítulo: "o que fazemos com as tecnologias e o que as tecnologias fazem conosco".

Perseguiremos, portanto, uma análise do fenômeno que não seja judicativa ou valorativa, agindo enquanto pesquisadores de forma condizente ao trabalho de um psicanalista. A esse respeito Calligaris (2019) é enfático ao afirmar que em nosso trabalho, olhar para as condutas humanas como louváveis ou condenáveis tem efeitos desastrosos. "A preocupação moral não é estrangeira ao trabalho psicoterápico, mas, para o terapeuta, o bem e o mal de uma vida não se decidem a partir de princípios preestabelecidos; eles se decidem na complexidade da própria vida da qual se trata. Um mesmo sintoma pode ser a razão do sucesso ou do fracasso de uma existência" (Calligaris, 2019, p. 20/21).

Posições nostálgicas, saudosistas, carregadas de uma sensação de fim dos tempos também nos parecem pouco fecundas. Essa é uma vertente bastante comum, que encontra voz através de bordões como estes, escutados por nós em um evento de enfermagem no Hospital da Lagoa (RJ) em maio de 2018: "Fale ilimitado, fale pessoalmente"; "A melhor operadora é o encontro". Apesar de termos lido psicanalistas que aderem a essa nostalgia, que elogiam de forma idílica os modos de subjetivação do passado, há muitos outros que rebatem essa inclinação. "Não devemos ser tecnofóbicos" (Laurent, 2017, p. 18) e, desde esse ponto de vista, pensa-se que "a saída não se apresenta por uma idealização do passado" (Jerusalinsky, 2017, p. 16) e que "é importante não perder de vista o risco de esbarrar em lamentações meramente saudosas de um mundo perdido e supostamente melhor" (Sibilia, 2015, p. 243). Ou, como defende Dessal, devemos procurar "estar sempre em dia com o presente" (Bauman; Dessal, 2017, p. 128).

Interessou-nos especialmente a postura de alguns analistas em exercício na atualidade que, não só criticaram posicionamentos nostálgicos encontrados no campo da psicanálise, como também propuseram ações novas, incluindo a internet. Acreditando que, em relação às novidades tecnológicas, não cabe a nós enquanto psicanalistas "abraçar a nostalgia ou festejar as boas novas" (Lyra, 
2019c, p. 05), Lyra nos convida ao desafio de não nos eximirmos de refletir sobre quais são, nesse contexto, as condições mínimas para a experiência singular, pesquisar modos com os quais os sujeitos encontram de inscrever, nessa nova arquitetura virtual, as suas marcas singulares" (idem). Com Fajnwaks (2019) retemos a mesma mensagem - não combina com um psicanalista ser nem tecnófilo, nem tecnofóbico - e aprendemos algo novo: nesse universo digital em que vivemos e trabalhamos, tal como propusera Lacan ${ }^{12}$ em referência ao pai, é preciso "servir-se da tecnologia para poder prescindir dela adiante". Sua proposta consiste em tentarmos construir uma posição ética que permita saber fazer com a cultura digital. Como? Utilizando os gadgets com certa serenidade, para poder ir além; incluindo-os no setting, na transferência, em nossos estudos, para fazer psicanálise a partir disso. Nesse uso, devemos procurar favorecer a aparição do sujeito, já que este sempre encontra seu jeito de subverter, com as tecnologias inclusive. A seu modo, Mena (2017) encaminha essa questão: “O gadget pode ser bom ou ruim, causa ou solução, a depender do uso que se faça. Talvez a orientação lacaniana sirva aqui como uma boa recomendação: "se passar dele à condição de nos servirmos dele"” (Mena, 2017, p. 224).

Outra tendência nos estudos sobre os impactos subjetivos da internet com a qual não nos afinamos é a dos exageros. Procuraremos evitar analisar o fenômeno excedendo as proporções de certos aspectos dele derivados. A seguir trazemos três colocações pinçadas de textos que lemos, as quais consideramos exageradas, ou seja, pouco condizentes com a realidade: "nossa existência está sendo transferida por inteiro ao mundo digital" (Dessal, 2017b, p. 03); "vemos "meninos de verdade" habitados por "falas de autômatas", provindas de suas relações com teclas e telas, intoxicados pelos aparatos eletrônicos, expostos a comandos fixos que falam neles" (Baptista e Jerusalinsky, 2017, p. 10); "se vive olhando para janelas virtuais, de corpo presente, mas psiquicamente ausente" (Jerusalinsky, 2017, p. 35)

Apostamos, então, em um caminho reflexivo que busca evitar moralismos, saudosismos, exageros, generalizações e relativismos absolutos. A partir das leituras realizadas e dos debates de que participamos nestes anos de pesquisa de

\footnotetext{
${ }^{12}$ A referência é à passagem na qual diz que é preciso "ultrapassar o Pai servindo-se dele". Lacan, J. (1975-1976). O Seminário, Livro 23: o Sinthoma: aula de 13/04/76. Rio de Janeiro: Jorge Zahar, 2007.
} 
doutorado constatamos que em todas essas posições há perigos para o psicanalista-pesquisador ${ }^{13}$. Aderir a qualquer uma dessas tendências no que diz respeito aos estudos sobre a rede seria, sem dúvida, uma grande armadilha.

Partindo da psicanálise para abordar a relação que temos com os computadores e smartphones, observamos que, quanto à internet e seus usos, a oferta de acesso é global, as possibilidades múltiplas, porém o uso que cada um faz da rede é singular e sintomático. "O uso desses objetos é universal. Aparenta ser da ordem do mesmo, mas qual o uso singular que cada um faz, qual a função inédita, inventiva, para cada falasser?" (Leduc, 2016b, p. 06). Dessal (2018) nos ensina que, desde o ponto de vista psicanalítico é preciso abordar o uso da tecnologia como "um sintoma", o que significa dizer que estamos diante de um real sobre o qual não cabe se extrair consequências gerais, mas sim estudar a função que dela adota cada sujeito em sua singularidade (Dessal, 2018, p. 01). Este autor considera que, como psicanalistas, nosso papel consiste em somar-se a outros enfoques - filosóficos, sociológicos, econômicos, políticos - com a finalidade de buscar compreender "a função que cumprem esses objetos técnicos em nossa vida" (Dessal, 2017b, p. 3). A importância desse enfoque pode ser constatada em situações como a que descreve Leduc: ao dar supervisões a analistas que atendem crianças e seus pais, procura ajudá-los a perceber que o cerne do trabalho está em "acolher a inquietude dos pais (em relação aos eletrônicos) sem, contudo, descartar o uso subjetivo que pode estar sendo feito pela criança" (Leduc, 2016b, p. 03).

Segundo Mamede-Neves (2006) "as redes interativas, como a Internet, que nada mais são do que uma intrincada malha constituída por equipamentos de conexão e computadores dos mais diversos tipos, ligados por meio de linhas comuns de telefone, de linhas de comunicação privadas, de cabos submarinos, de canais de satélite, entre outros meios de telecomunicação, apenas dão condições à comunicação ou propiciam um diálogo planetário. A técnica nos dá certamente, poderes, mas a escolha do que vamos transmitir através dela é nossa" (Mamede-

${ }^{13}$ A figura do psicanalista-pesquisador foi proposta por Fortes \& Macedo no ensaio "Quem é o psicanalista pesquisador? Questões cruciais sobre o método psicanalítico de pesquisa", para descrever a função e modo de fazer pesquisa de quem é psicanalista e ao mesmo tempo insere-se em programas de pós-graduação, enfrentando o desafio do ensino da psicanálise na universidade e o enfretamento das exigências de métodos de pesquisa avalizados pelo sistema nacional de pósgraduação e pesquisa. (Publicado em Kupermann, D.; Birman, J; Fulgencio, L; Leal Cunha, E. (ORGS.). Modalidades de pesquisa em psicanálise: métodos e objetivos. São Paulo: Editora Zagodoni, 2018). 
Neves, 2006, p. 181). É um processo dinâmico que está em jogo ali. E, aqui, volta-se a este importante ponto: o problema maior não é a internet em si, mas o uso que se faz dela.

A internet abre espaço, assim, para múltiplos usos e provoca, consequentemente, efeitos distintos. Cada sujeito utiliza a rede a seu modo e, por essa razão, as consequências clínicas precisam ser avaliadas caso a caso. O que está tendo bons efeitos para um paciente pode estar causando sofrimento para outro. Um mesmo hábito de acesso (como, por exemplo, a postagem de fotos no Instagram ou a paquera via Tinder) pode ser sentido como uma experiência gratificante ou lamentável para uma mesma pessoa, inclusive, dependendo de outras contingências de sua vida ou do momento pelo qual está passando. Sobre estas variações e oscilações, encontramos nos estudos de Audibert (2008) impressões justamente relacionadas à interface entre possíveis vícios e a solidão, um dos temas centrais desta tese. Para algumas pessoas, pontua a autora, na lida com a solidão, ao procurarem tentativas para solucioná-la, o que seria um "remédio" torna-se um "veneno", porque se entra num espiral aditivo (Audibert, 2008, p. 12).

Sobre essa importância de analisarmos cada caso como único, cada uso da internet em sua singularidade, alguns psicanalistas têm se posicionado, como os que traremos a seguir: Dunker (2017b) salienta que "as redes sociais jamais deveriam ser entendidas como um instrumento de mão única e de uso compulsoriamente semelhante para todos" (Dunker, 2017b, p. 138); Laurent (2014), por sua vez, afirma que, em relação aos objetos digitais, "trata-se de cada um fazer à sua maneira, mas com os mesmos objetos" (Laurent, 2014, p. 43); Veras (2019) refere-se ao mundo das telas em que vivemos dizendo que "do genoma ao screenoma: cada um manipula seus celulares de um modo único".

Freud nos ajuda a embasar tais colocações a partir das orientações que nos deixou em "O mal estar na civilização" (1930). Frente aos inúmeros recursos que temos na cultura para lidar com as durezas da vida deixa a "sugestão de cada qual cultivar seu jardim" (Freud, 1930/2010 p. 28). Para ele, "cada um tem que descobrir a sua maneira particular de ser feliz" (p. 41). E, se é assim, propomos que a internet seja pensada como mais um elemento a ser incluído no processo de cada um de cultivo da própria vida, somando-se a esse exercício constante que 
fazemos de descobrir caminhos para a felicidade (sempre transitória, é importante frisar).

No que diz respeito à interferência deste recurso tecnológico no fenômeno da solidão, acreditamos que possa tanto amenizar, quanto acentuar a solidão de cada um, já que a tela que conecta é a mesma que pode distanciar. O mesmo vale para a manutenção de laços afetivos já existentes ou para a criação de novos laços. Karnal (2018) ilustra com clareza esse leque de possibilidades na seguinte afirmação: "Tenho certeza de que algumas pessoas encontram conforto e pertencimento na internet. São realmente felizes, têm amigos e vivem de forma real no mundo virtual. Para cada uma delas, contudo, existe outra (talvez dezenas ou centenas de outras) que mergulhou em uma solidão perniciosa e nefasta" (Karnal, 2018, p. 52).

Como "a internet favorece a multiplicidade das expressões" (Serres, 2013, p. 78) e "a plasticidade da Rede de fato faz com que dela possamos fazer muitos usos" (Romão-Dias, Nicolaci-da-Costa, 2012, p. 100) não se pode afirmar de antemão de que maneiras recorrer a ela afetará a vida de alguém. Sobre isso, selecionamos posicionamentos interessantes de alguns psicanalistas, os quais apresentamos a seguir. Vale destacar que a leitura destes autores em relação à web está marcada pela não polarização, ou seja, todos transmitem a mensagem de que em uma reflexão sobre essa rede que por si só é múltipla e plástica não cabe um pensamento dicotômico. A internet enquanto fenômeno não é binária; o próprio “objeto internet" é por si só múltiplo e plástico ${ }^{14}$.

Gueller (2017) afirma que "a rede é democrática e universaliza, mas o que para uns é bom, para outros, pode ser deficitário ou excessivo" (Gueller, 2017, p. 73). Leduc (2017) sublinha o fato de que "os modos de gozar em atividade na internet são múltiplos, e também heterogêneos, às vezes concomitantes entre eles e sujeitos a uma hibridação ao infinito" (Leduc, 2017, p. 04). Nobre e Moreira (2013) definem a rede como uma nova forma de sociabilidade humana, "uma nova modalidade de compartilhamento social" e, sendo assim, "a realidade virtual representa uma multiplicidade alternativa" (Nobre e Moreira, 2013, p. 290) (grifo nosso). Apontam em seu artigo para aspectos positivos e negativos do uso das redes, concluindo-o com a seguinte mensagem: "Se, por um lado, a experiência

${ }^{14} \mathrm{O}$ que, nesta tese, denominamos "objeto internet" refere-se às múltiplas formas de utilização da rede. 
subjetiva no ciberespaço favorece a expansão do imaginário que parece materializar-se virtualmente aos nossos olhos, por outro, a quase ausência de limites não pode deixar de suscitar cautela quanto às consequências que possam daí advir para as gerações em formação” (p. 295).

Em continuidade com a postura defendida por Pitliuk, exposta mais acima, o psicanalista argentino Goldenberg (2017) se propõe a tratar do assunto "com um tom menos apocalíptico do que aquele que se deixa ouvir em muitos ensaios" (Goldenberg, 2017, p. 84). Sugere incluir os gadgets em nossas vidas e explorar suas possibilidades ao máximo ao invés de combatê-los em nome de uma pureza anacrônica (p. 85). Devemos nos "aparelhar com tudo o que a informática tem de melhor" (p. 86). Interessado e ao mesmo tempo avesso à adesão à nostalgia, refere-se a um ditado muito corrente em seu país de origem, que alardeia que "todo tempo passado foi melhor". Sobre essa evocação de um passado glorioso comenta que "este sentimento de um presente tenebroso e um futuro catastrófico iluminados por um passado feliz, é uma constante no espírito humano desde sempre" (idem, p. 79).

Esse paralelo entre presente e passado também inspirou Mena (2017) em suas reflexões. Chamou-nos especialmente atenção a forma como apresentou o tema da ligação entre as pessoas na era da internet nesse seu artigo. Abrindo a discussão com a pergunta “Conexão ou desconexão?", deseja, contrariamente ao que à primeira vista pareceria, explorar que se trata aqui de um "ê" e não de um "ou" (postura semelhante a que defendemos anteriormente, sobre a internet ser boa ou ruim). Para ilustrar o que pensa sobre as novidades (ou permanências) trazidas pela rede, descreve uma postagem vista no Facebook, em que figuram lado a lado duas fotos, uma dos anos 1960 e a outra dos anos 2000. Em ambas, há pessoas em um trem, que não conversam umas com as outras. Na primeira, as cabeças curvadas e os olhos atentos estão voltados para jornais e revistas; na segunda, para smartphones e tablets. Mena sublinha que o comportamento em si é exatamente o mesmo e que o que muda são os objetos: ora de papel, ora eletrônicos. "As pessoas sempre tiveram seus "momentos de cabeça curvada", afirma (Mena, 2017, p. 212). Mas então porque a preocupação atual? Será que não há diferenças? Mantenhamos em aberto a pergunta, a fim de irmos construindo possíveis respostas a partir do que seguiremos discutindo nas próximas páginas. 
É interessante comentar que na medida em que íamos lendo textos de psicanalistas a respeito da internet passamos a notar, do meio para o fim da pesquisa, a presença cada vez mais forte da expressão "por um lado... por outro lado...”. O uso dessa expressão e das ideias que eram desenvolvidas a partir dela nos fez entender que o desenvolvimento tecnológico comporta forças contraditórias e que tal fato convoca a necessidade de um olhar crítico. O psicanalista francês Serge Tisseron (2015) exemplifica bem essa postura a qual estamos nos referindo. Ao refletir sobre as utilizações das tecnologias digitais frisa a importância de usarmos o plural, visando justamente destacar que os usos são diversos e que há, portanto, inúmeras relações possíveis com os objetos virtualizados de nossas telas, assim como inúmeros efeitos subjetivos daí decorrentes.

No livro "Sonhar, fantasiar, virtualizar" (2015) Tisseron é mais uma voz dentre as que sustentam que entre essas ações humanas que compõem o título de sua obra há uma proximidade, uma continuidade e não uma oposição. Em suas palavras: "A virtualização tem dois polos que são como duas irmãs gêmeas, para não dizer inimigas: uma do lado do empobrecimento do mundo, a outra do lado da multiplicação e de seu enriquecimento. Com efeito, de um lado a virtualização suprime o corpo, carne, emoções, a rigor ela suprime a humanidade e a reduz ao estado de objeto. Mas de outro lado ela utiliza a capacidade de abstração para fazer novas sínteses que são o ponto de partida de novas representações" (Tisseron, 2015, p. 12).

Acompanhando o autor, constatamos que, de um lado, a internet multiplica nossas capacidades de descoberta e de intervenção no mundo, mas, de outro, contribui para favorecer a retração da realidade e banalizar o processo de clivagem. Os comportamentos tão frequentes e naturalizados de fechar janelas de sites, de encerrar uma conversa com um clique ou de deletar um contato abruptamente ilustram bem essa segunda possibilidade apontada por Tisseron. Assim, aquele que deseja utilizar a internet para aumentar sua compreensão sobre o outro o consegue, mas aquele que deseja reduzir o mundo a algumas ideias prontas também o consegue. Isso porque essas tecnologias servem muito precisamente aos objetivos que lhes designamos. Os que são capazes de virtualizar suas percepções para introduzir novas atualizações encontram nas telas um extraordinário suporte para fazê-lo melhor. Por outro lado, os que querem 
fugir do mundo e ignorar o ser humano o podem igualmente. A afirmativa de Birman citada anteriormente, a respeito de um coro coletivo contemporâneo que brada "Foda-se o outro!" se encaixa nesses casos. Tisseron conclui então que a relação com um objeto virtualizado numa tela abre ao mesmo tempo novas possibilidades de multiplicação criativa e de redução manipuladora, ao preço de clivar a realidade e coisificar o ser humano. "As tecnologias digitais estão a serviço tanto da ligação quanto da fuga" (Tisseron, 2015, p. 171).

\subsection{1) Exemplos variados da cultura}

Através de uma reportagem na revista francesa Psychologies (2013) tomamos conhecimento da história de Julie, uma moça de 29 anos que estabeleceu uma relação de dependência e sofrimento com as telas, das quais "não podia mais privar-se". Ao constatar que estava vivendo um quadro de "bulimia virtual" (nomeação interessante que ela mesma criou para falar dessa dependência) aproveitou um problema de saúde que a forçou a se desconectar para analisar sua necessidade de estar ligada permanentemente, passando a se fixar regras, imprimindo para si uma transformação significativa.

Com a palavra, Julie: “Twittar dez vezes por dia informações, postar fotos no Instagram, localizar endereços novos e partilhá-los no mesmo instante, seguir uma mensagem no Facebook, responder a um e-mail às duas da madrugada, nem um dia se passava sem que eu estivesse conectada. Mesmo durante minha viagem de bodas na Itália! Eu estava apanhada pelas telas: abria meu computador antes de tomar café da manhã, adormecia com meu smartphone, eu navegava horas a fio sem me dar conta, sendo fim de semana ou não. Podia me multiplicar ao infinito, assistindo a uma série de televisão, seguindo várias conversas no Twitter e jogando ping-pong nas quarenta janelas abertas simultaneamente em meu computador. Praticava exercícios com os olhos na tela e com o fone no ouvido. Tudo era urgente. Eu amava essa sensação de superpoder, de estar viva. Eu trabalhava com internet, mas não me dava conta de que passei a trabalhar permanentemente. Em fevereiro, caí doente. Estava esgotada, o cérebro prestes a explodir, no limite do burn-out. Não tinha mais energia para cuidar da minha imagem. Compreendi que minha bulimia virtual tapava meu mal-estar. Quanto mais eu me sentia mal, mas me enfiava na Net. Mentia para mim mesma, 
difundindo nas redes sociais uma imagem de uma Julie cintilante, dinâmica, bem consigo mesma. Paradoxalmente eu não sentia falta de nada. A enxurrada de mensagens para responder (tenho 700 seguidores no Twitter, sigo 134, tenho 869 amigos no Yelp, 670 no Face profissional, 84 assinantes no Instagram e 50 que olho) tinham para mim o efeito de um monte de pedras que me esmagavam. Ficava parasitada por informações inúteis vindas pelo smartphone. Começar uma terapia me ajudou a ver que eu tinha necessidade de estar conectada permanentemente. Essa adicção vinha a calhar com relação ao medo de perder qualquer coisa, mas sobretudo a uma angústia profunda, a da solidão. Eu existia através dos outros. (...) Para não me deixar raptar novamente pelas telas fixei certas regras: nada de computador no quarto, conectar-me somente após o café da manhã, telefone no silencioso e escondido à noite e nos fins de semana. Deixei de ser onipresente".

O "mesmo" Twitter teve um efeito absolutamente distinto para o astro do teatro chileno Hernán Letelier, falecido no início de 2020 aos 99 anos. Seu caso é ilustrativo do incremento na sociabilidade de idosos que puderam encontrar, através da internet, uma via de comunicação em meio a situações de isolamento não opcional. A matéria no jornal "El País" (2016) intitulada "Aos 95 anos no Twitter" explora esse exemplo, em que a descoberta dessa rede social produziu fascínio, pelo fato de ter repercutido positivamente contra a solidão sentida por este senhor.

Por conta da idade avançada, Letelier fora esquecido pelas novas gerações e vivia tempos especialmente difíceis. Ao receber a visita de uma amiga no Natal, lhe contou que 2015 havia sido horroroso, pois passou cinco meses prostrado na cama por causa de uma pneumonia complexa, praticamente sozinho. Sobre esse estado de solidão, comenta: “Tive uma família estupenda, mas minha mãe faleceu, e meu único irmão morreu muito jovem. Não me casei nem tive filhos, e meus tios e primos estão todos mortos. Também minhas grandes amigas e amigos da alma. Na idade que eu tenho, não resta ninguém vivo". A cultura, sob todos os âmbitos, está presente nesse lar acolhedor, como a ferramenta-chave para manter a mente jovem e o corpo menos trêmulo. Apesar de manter-se lúcido, culto e ativo intelectualmente (lê, canta e recita poesias diariamente), a riqueza proveniente das trocas com pessoas lhe fazia falta. Sentia saudades da época em que a intensa vida 
social recheava os dias dessa Santiago cultural de meados do século. Algumas vezes, se sentiu muito deprimido, sem vontade de viver.

Ao ser apresentado ao Twitter por essa jovem amiga que veio visitá-lo viu ali uma oportunidade e, rapidamente, a vontade de se conectar passou a funcionar como vontade de viver. Seu primeiro tuite foi um sucesso, em poucas horas tinha mais de 900 seguidores. Seu depoimento revela o potencial de transformação desta nova ferramenta para ele: "É como nascer de novo. Estar no mundo é estar vivo, e o que está vivo, conversa. Aos 95, me sinto cheio de possibilidades criativas. Queria que o que me resta por viver, que não é muito, fosse rico em experiências. Tenho interesse nos seres humanos e quero viver entre os vivos, com os vivos e, se possível, para os vivos".

Com o título "As redes sociais mudaram suas vidas" a revista francesa Psychologies (2012) nos apresenta as histórias de mais três sujeitos que estabeleceram com a internet ligações cujos efeitos os impactaram consideravelmente. Aude, 43 anos, é mãe de três crianças e trabalha muito. Sua vida social pôde retomar alguma dinâmica através das redes sociais, quando, teclando à noite, passou a ter um tempo para descansar e partilhar. "Não sinto estar substituindo minha vida por uma vida virtual, mas sim estar enriquecendo e criando trocas que eu já não tinha, de qualquer forma, tempo físico de viver. É como um jantar em casa, sendo que posso estar de pijamas e não precisarei lavar a louça de 150 amigos!", diz a bem humorada Aude.

Claudine, 56 anos, experimentou efeitos transformadores através do jogo Second Life (mundo virtual em 3D onde se encarnam personagens), que segundo ela, a liberou sexualmente. Sentindo-se terrivelmente sozinha após uma separação, acabou cedendo à pressão das filhas e se inscrevendo em sites de encontro. Trocou mensagens durante uns dez dias com um homem, se encontraram, foi ótimo, mas durou pouco, não deu certo. Anos depois voltaram a se falar e se reencontraram no Second Life. Escolheram os personagens mais jovens e bonitos. Durante três meses, diariamente após o trabalho, partilharam um pedaço de vida juntos. Reencontraram-se virtualmente em um barco, em lojas, ele lhe oferecia tudo com que ela sonhava. Jantaram em restaurantes, conversaram enquanto dançavam em lugares idílicos e fizeram amor na praia. Escreviam-se pela pequena janela do computador, sobre tudo, sobre nada, sobre assuntos jamais abordados. Tais conversas duravam de cinco a oito horas. Segundo Claudine, S. L lhe deu 
confiança em seu amor. Ali, ela e o "parceiro" aprenderam a se conhecer melhor, sendo mais naturais, sinceros e expressivos. Através dos personagens reencontraram a impetuosidade de suas juventudes. O mais surpreendente: meses depois, fecharam as contas nesse jogo virtual. Não havia mais necessidade, pois passaram a viver juntos.

Para Nans, 34 anos, os jogos eletrônicos trouxeram alguns benefícios: ele consegue manter a ligação com o irmão que vive em Washington, com quem fala das estratégias e também conversa sobre outros assuntos. Fez uma dezena de amigos no meio virtual, com os quais se encontra também pessoalmente. Em seu grupo de jogo transita entre pessoas de todas as idades, assim como entre algumas com deficiências, gente com quem nunca havia interagido em sua vida. Assim, pôde perceber que essa sua imersão na internet provocou uma mudança em seu olhar sobre as diferenças interpessoais. "Com esse hobby, percebo o mundo em sua globalidade", comenta Nans.

\section{5) A internet pensada pela via da complexidade e dos paradoxos}

Um computador hipertextual, disperso, vivo, pululante, inacabado, virtual, um computador de Babel: o próprio ciberespaço.

Pierre Lévy, O que é o virtual?

Em contrapartida às compreensões judicativas e valorativas, encontramos autores que estão pensando a internet pelo viés da complexidade. No artigo "Nós e a internet”, Gonçalves (2006) transmite com clareza essa mensagem, ao afirmar que "temos então entre tecnologias de comunicação e subjetividade uma relação bastante complexa" (Gonçalves, 2006, p. 247). Discordando das perspectivas apocalípticas e integradas em relação à web sugere estarmos agora no momento de tentar uma compreensão mais refletida e mais nuançada, que fuja da "excessiva generalidade que é também uma limitação" (p. 235). A autora legitima a importância de leituras que produzam uma visão global que capta o todo, pois certamente têm seu valor, por exemplo, para a leitura histórica de uma época. Sublinha, porém, que a psicanálise tem mais afinidade com as especificidades e que, justamente por isso, não pode de forma alguma deixá-las de lado. 
A argumentação em prol da complexidade que é a internet ganhou força com a leitura do livro "Desejos digitais: uma análise sociológica da busca por parceiros on-line" (Miskolci, 2017), no qual, já no prefácio, encontramos o seguinte comentário: "Quando o autor se pergunta se "as mídias digitais permitiam efetivamente aos sujeitos escapar do heterossexismo cotidiano" sua resposta é sofisticada. Não cabe em monossílabas" (grifos nossos). O livro do professor e pesquisador em sociologia digital aborda o tema das "paqueras mediadas", isto é, a seleção de parceiros por meios digitais. Distanciando-se definitivamente da noção anacrônica de que virtual e real são esferas opostas Miskolci concebe a internet como um espaço que proporciona ao sujeito desejante a possibilidade de vivenciar em segurança as múltiplas facetas de sua sexualidade.

Tal obra problematiza (grifo nosso) as expectativas desses usuários de respostas técnicas para dilemas culturais e políticos, bem como as profecias distópicas sobre o caráter potencialmente destrutivo da tecnologia para as relações sociais. Adotando uma perspectiva que reconhece o caráter social, criativo $e$ aberto (grifo nosso) dos usos da tecnologia defende que "os desejos atuais, aqui chamados de digitais, não são menos sociais ou eróticos que os anteriores" (Miskolci, 2017, p. 48). Como observou um dos homens entrevistados para a pesquisa que deu origem ao livro "o encontro efêmero e seguro pode parecer "não o ideal, mas o possível"' (grifo nosso).

Uma das conclusões a que chega o pesquisador toca em diversos pontos polêmicos e exprime com precisão ideias com as quais passamos a concordar em nossa trajetória de pesquisa. Vamos a ela: "Assim, não cabe demonizar as tecnologias digitais por vender o que não podem prover. Primeiramente, porque elas efetivamente permitem encontros e, segundo, porque não lhes cabe transformar as condições políticas em que vivem seus usuários" (idem, p. 286). Artefato "vivo e pululante" como descrevera Lévy, o computador tem tanto funções sociais, como limitações. Enquanto "um palco alternativo oferecido para o desenrolar dos mais diversos aspectos da vida" (Nicolaci-da-Costa, 2006, p. 11) (grifo nosso) a internet dá lugar a novas encenações, em que figuram os inéditos e também os antigos dramas humanos.

Ao assistirmos a uma palestra de divulgação de resultados das Pesquisas TIC EDUCAÇÃO e TIC KIDS ONLINE BRASIL atentamos para mais um ponto que testemunha a complexidade das TICs (tecnologias de informação e 
comunicação). Focando no uso que crianças e adolescentes têm feito das redes, os estudos destacam que há riscos e oportunidades. A realização de atividades escolares na rede, o engajamento político, as conversas com pessoas de outras culturas, a produção e circulação de textos de própria autoria compõem a lista de exemplos de que há então um empodeiramento desse público ao usarem a internet. Com ela, aprendem e criam novas habilidades que incrementam seus repertórios. É interessante notar que essas pesquisas da GLOBAL KIDS ONLINE apontam para a existência de riscos, de incertezas, mas não os consideram necessariamente como danos. Veem nos riscos oportunidades, possíveis fontes de aprendizado. Essa ênfase que deram à ambivalência da palavra "risco" nos interessou, pois parece sinalizar justamente a pluralidade de possibilidades que certos fenômenos comportam. A pergunta formulada por Lima dialoga com esses aspectos, enriquecendo a indagação construtiva a que nos lançamos: "Quais as possibilidades e os riscos que a cultura digital produz?" (Lima, 2017, p. 08).

A ideia de que a internet é algo complexo também foi se evidenciando para nós através dos inúmeros paradoxos que foram (e seguem sendo) enunciados a seu respeito. Essa dimensão paradoxal ${ }^{15}$ - que interessa à psicanálise precisamente por ser algo que está em conflito com o senso comum, mas nem por isso é uma inverdade- é rica de ser explorada. Por ora, traremos alguns exemplos de paradoxos com os quais nos deparamos, para adiante, ao longo do restante da tese, os explorar mais a fundo.

A tecnologia torna o trabalho mais eficiente, podemos fazer mais em menos tempo por causa de seus dispositivos. Entretanto, não temos mais tempo livre, já que nos são oferecidas formas inteiramente novas para entreter e consumir tempo, como navegar nas redes sociais, pesquisar em sites, jogar online, assistir vídeos no Youtube, conversar por Whatsapp. Eis então o paradoxo: as mesmas ferramentas que nos permitem fazer mais em uma unidade de tempo, também consomem o tempo que economizamos. Sobre isso, comenta Flanzer, já denunciando a exigência de mais compromissos que nos capturou: "Economizamos tempo com a modernidade, mas não o usamos com ócio

\footnotetext{
${ }^{15}$ O verbete "paradoxo" do Dicionário de Filosofia J. Ferrater Mora, Edições Loyola, 1994, tomo III ajuda na compreensão dessa noção. Dentre as definições da noção de paradoxo ali presentes, nos encantou especialmente a que os caracteriza como "coisas que maravilham": "o paradoxo maravilha porque propõe algo que parece assombroso que possa ser tal como se diz que é" (Mora, 1994, p. 2200).
} 
produtivo. O que fazemos com os 40 minutos que gastávamos na fila do banco?" (Flanzer, 2017).

Com relação ao par 'aproximação-afastamento' ou 'conexão-solidão' é dito que a internet pode aproximar as pessoas e ao mesmo tempo pode acomodar (ou até mesmo estimular e alimentar) o sujeito que tende ao isolamento. Sibilia (2015) se interessa por essa questão e ilustra tal paradoxo com o mesmo filme "Denise está chamando" cujas análises expusemos mais acima. A obra lhe surpreendeu "porque seus protagonistas jamais se encontravam fisicamente, embora se relacionassem profusamente através de diversos dispositivos de comunicação" (Sibilia, 2015, p. 104) (grifo nosso). Às voltas com essa questão, provoca o psicanalista espanhol Dessal (2017b): “A tecnologia é divulgada como vantajosa por invocar o ideal da proximidade, mas pode, ao mesmo tempo, produzir o efeito contrário" (Dessal, 2017b, p. 09).

Tais paradoxos são postos em cena, por exemplo, nas situações extremamente comuns e altamente criticadas de hoje em dia, nas quais um casal (supostamente romântico) está junto, cada um no seu celular. Goldenberg (2017) problematiza esse fenômeno, com a seguinte indagação: "Talvez seja graças ao Whatsapp e ao Facebook que aqueles dois entediados permanecem juntos até hoje. Como saber (e como saber se é bom que permaneçam juntos)?" (Goldenberg, 2017, p. 82). Outra situação que evoca essa dimensão paradoxal trazida por este autor é descrita a seguir: "Quando se trata de divulgar um evento, ao qual comparecerão pessoas reais, não existe meio melhor que a própria página no Facebook, que é virtual" (idem, p. 84).

O tema da 'liberdade-aprisionamento' também produz paradoxos envolvendo a rede. Para abordá-los partiremos de três pensadores que se interessaram por este aspecto, cada um a seu modo. Julieta Jerusalinsky (2017) indaga: "Se, por um lado, navegar pela internet nos traz a ilusão de liberdade, as buscas realizadas virtualmente deixam como rastro a pegada digital" (Jerusalinsky, 2017, p. 24). Para ela "essa exaltação narcísica apresenta, em sua contracara, uma faceta melancólica, em que o sujeito se sente esvaziado de sentido, com a "bola murcha", ao se comparar à "bola cheia" da plenitude imaginária que virtualmente constitui para si” (Jerusalinsky, 2017, p. 23). Segundo esse ponto de vista, a internet estimula a mostração por um lado e, por 
outro, inibe e angustia. Assim, por um lado envaidece e apazigua, por outro, devasta quando alguém se vê massacrado pelo retorno de uma exposição.

A tensão permanente entre sermos livres e/ou estarmos aprisionados pelos fascínios e armadilhas da rede se explicita também por alguns pontos delimitados pelo filósofo alemão Christian Türcke (2010) em seus estudos sobre o comportamento dos indivíduos que habitam nossa "Sociedade excitada" (título que dá a um de seus livros). Para este autor, apesar de sermos livres para publicar o que quisermos e de podermos ter acesso à rede na hora que escolhermos, estamos submetidos a uma "pressão para emitir" (Türcke, 2010, p. 39) e a uma "compulsão a emissão ${ }^{16 "}$ (idem, p. 44) que testemunham o oposto: a dependência dos eletrônicos traz um caráter de aprisionamento às nossas escolhas. De forma análoga o filósofo sul-coreano Byung-Chul Han aponta tal paradoxo, referindo-se especificamente à importância que passamos a dar aos nossos smartphones. Destes aparelhos, "que prometem mais liberdade, parte uma coação fatal, a saber, uma coação da comunicação. Com isso se tem uma relação quase obsessiva, compulsória com o aparato digital. Também aqui a liberdade se inverte em coação" (Han, 2018, p.65).

A questão da quantidade de informações que circulam e das mensagens em palavras que trocamos uns com os outros também é rica em paradoxos. Flanzer (2017) aponta que o excesso de informações e de palavras com o qual povoamos o nosso dia, não necessariamente se reverte como firmeza em nossos compromissos. Falamos muito e fazemos pouco. Nossos compromissos estão mais esgarçados, as palavras estão se tornando mais gastas, menos levadas a sério.

De nossa clínica trazemos a enunciação de um paradoxo pela voz de uma paciente adolescente que segue diversas páginas do Instagram destinadas à autoajuda. Tomada de angústia e dizendo-se perdida, relata à analista a experiência vivida nos dias anteriores: "Eu estava mal e fui ler mensagens sobre tristeza. As primeiras páginas que li diziam "Sinta-se alegre hoje, celebre a vida, conecte-se com energias positivas". Funcionou por umas horas, mas logo fui ficando agoniada de novo. Voltei a acessar o Instagram e dessa vez li propostas

\footnotetext{
${ }^{16}$ Essa expressão cunhada por Türcke nos remeteu ao conceito psicanalítico de "compulsão à repetição" (FREUD, 1920/1996, p. 31), podendo vir a ser um estímulo para novas explorações de pesquisa.
} 
opostas: "Respeite seus sentimentos, viva a tristeza que está em você". Aí fiquei ainda mais confusa e angustiada".

\section{6) Real e Virtual entrelaçados: mundo online e mundo off-line como um contínuo}

Falamos mais, escrevemos mais, nossas vidas se tornam cada vez mais públicas e compartilhadas no mundo virtual. E no mundo real? Cabe essa distinção hoje entre mundo real e mundo virtual? Não é o mundo virtual muitas vezes mais real que o real?

Maria T. Cavalcanti, Prefácio a Nomofobia

A linha divisória entre o mundo real e o virtual se apaga a uma velocidade tamanha, que jamais havíamos imaginado.

Gustavo Dessal, Conectados o desconectados?

A discussão levantada por Cavalcanti (2014) neste extrato é mais um ponto que nos pareceu pertinente de ser explorado neste capítulo inicial da tese. A investigação do que tem sido pensado a respeito desse novo universo criado junto à internet - o mundo virtual ou cyberuniverso ou mundo online - é fundamental, a nosso ver, para subsidiar um estudo sobre a rede que pretende explorar as complexidades e evitar as polarizações. Isso porque, assim como na valoração da internet como boa ou má para os relacionamentos abundam posturas que se agarram a um dos lados, também aqui encontramos esse modo de compreensão do mundo que separa cada coisa de um lado, sem atentar para o "entre", para as misturas. Além disso, há um discurso sobre aqueles que navegam bastante na internet de que existe uma substituição da realidade "real" por uma realidade "virtual”, sendo esta ilusória, mentirosa e pouco estável. Com esta seção pretendemos, portanto, problematizar tais posições e explicitar aquela com a qual nos identificamos, a que considera "os mundos" real e virtual como distintos, porém, interligados ${ }^{17}$.

${ }^{17}$ Vale notar que não buscaremos aprofundar ou sistematizar a problemática epistemológica bastante trabalhada - das noções de real e de virtual. Este problema nos interessa aqui em sua 
O verbete "virtual" escrito por Romão-Dias (2006) é esclarecedor sobre esse aspecto. Dentre as muitas definições que apresenta, contextualizadas dentro de um amplo panorama, destacamos o trecho em que a autora aponta para existência de uma dicotomia entre a "realidade real" e a realidade virtual (RomãoDias, 2006, p. 522) (grifo nosso), no momento histórico em que surgiram as novas tecnologias digitais. Segundo a autora, naquele momento foi reacendida uma antiga concepção que opunha real e virtual, a qual se tornou hegemônica. O virtual voltou a ser visto como o "outro" do real. Em nossa pesquisa nos deparamos com exemplos dessa dicotomia (da qual discordamos e estamos nos esforçando para ajudar a desconstruir) e é com eles que começaremos nossa exposição.

Em cartaz no Teatro Cândido Mendes no Rio de Janeiro em outubro de 2019 a peça "No virtual todos somos felizes", com direção de Anselmo Vasconcellos, parece denunciar desde seu título a tendência à idealização e à maquiagem da vida real no mundo virtual. De modo semelhante, os humoristas do programa "Porta dos Fundos" caricaturam de forma muito bem humorada essa dissimetria entre o que se vive na vida real e o que se publica nas redes sociais no episódio "Vida Real". Protagonizado por um mendigo que encontra um colega que se surpreende com o enorme contraste entre seu estado de pobreza e as viagens internacionais que alegram sua página no Facebook, o episódio alerta a sociedade sobre essa nova possibilidade que a internet traz. Karnal (2018) teoriza sobre esse fenômeno encenado pelo campo das artes afirmando que "na internet não há mazelas que eu não queira que haja. (...) Os recalques do cotidiano somem diante da fragmentação e da reconfiguração do "eu real" no "eu virtual"” (Karnal, 2018, p. 51).

Apesar de concordarmos que muitos sujeitos contemporâneos têm tentado se apartar de suas realidades mergulhando suas vidas no mundo virtual, consideramos problemáticos os posicionamentos que tendem a separar real e virtual, posicionamentos que dão a entender que podemos viver vidas paralelas que não se afetam mutuamente. Os que são totalmente felizes no virtual, como sugere a peça teatral, certamente não o são no real. E ainda que se enganem momentaneamente sobre suas condições ou que façam os outros acreditarem que

articulação com o objeto de estudo da presente tese, a solidão e o laço com o outro na era da internet. 
estão ótimos, experimentam dissabores. O mendigo que se finge de homem bem sucedido na rede social não deixa de passar fome, de não ter aonde dormir.

A pesquisadora Sherry Turkle traz um exemplo muito interessante para incrementar essa polêmica. Em suas pesquisas, teve a oportunidade de entrevistar várias pessoas que achavam a vida online mais satisfatória do que a vida real. Em seu livro "Alone Together" (2017) cita o caso de Doug, um estudante universitário que possuía quatro avatares distribuídos em três mundos online diferentes. Ele sempre tinha esses mundos abertos como janelas em sua tela de computador, juntamente aos trabalhos escolares, e-mails e jogos favoritos. Com facilidade, costumava passear através deles todos. Na conversa com Turkle disse que a vida real - RL (real life) - "é apenas uma janela a mais", e que, “normalmente não é a sua melhor” (Turkle, 2017a, p. xii).

Encontramos em Paulo Vaz, mais precisamente em algumas de suas elucubrações sobre a internet, elementos ricos para aquecer essa discussão. Segundo este pesquisador da área da Comunicação "nossa cultura inventa máquinas que parecem ter vida e cria, para nossa vida ordinária, a concorrência de uma outra vida no interior das máquinas" (Vaz, 2000-2002, p. 05) (grifo nosso). Define a internet como "uma tecnologia onde vale a pena viver", onde um número cada vez maior de indivíduos passeia, estabelece amizades e pratica sexo. Vaz afirma a existência de uma nova forma de vida propiciada pela existência do universo online, mas deixa em aberto quais são as implicações desta na vida que se leva quando não se está plugado. Há uma "outra vida", ela é atraente em muitos aspectos, mas nem por isso podemos abdicar por completo da "vida como ela é" (aquela que inspirara Nelson Rodrigues em sua obra).

A posição que construímos a esse respeito, a qual partilhamos com diversos autores (cujos nomes e ideias apresentaremos em seguida) baseia-se na crença de que real e virtual são dimensões entrelaçadas, misturadas. $\mathrm{O}$ virtual não antagoniza com o real. Um modifica o outro, são mundo permeáveis, que se interferem mutuamente. Se até certo momento da história ainda restavam dúvidas quanto a isso, a explosão mais evidente dessa fronteira se deu com a criação dos dispositivos móveis de comunicação, os smartphones.

Para Miskolci (2017) dado que "vivemos em um mundo em que as relações são crescentemente mediadas tecnologicamente, torna-se patente a falácia da oposição real / virtual e cada vez mais clara a existência de um contínuo on- 
line / off-line" (p. 47). O autor vê como "superada a distinção virtual / real que seguia a -hoje sabemos - ingênua interpretação de que as interações on-line ocorriam em um outro espaço" (p. 21). Seguindo com sua argumentação, esclarece que "o advento da internet 2.0, a expansão da banda larga, a chegada das câmeras digitais e a popularização de equipamentos móveis para acessá-la permitiram que a rede se imiscuísse de tal forma no cotidiano que já não evoca qualquer separação entre o que se faz dentro ou fora dela. A vida conectada em rede começou a contestar a separação entre on-line e off-line, assim como a de que seria possível viver em um espaço alternativo e com regras próprias. Não só as normas do velho cotidiano face a face moldam nossas relações on-line, mas também - desde que o acesso à rede se disseminou - as características das interações por mídias digitais têm passado a modificar as do dia a dia" (Miskolci, 2017, p. 22).

Em linhas gerais, analisando a passagem da modernidade à contemporaneidade, observa-se que várias dicotomias foram desmanteladas, como, por exemplo, entre natureza $\mathrm{X}$ cultura, realidade $\mathrm{X}$ ficção, verdade $\mathrm{X}$ mentira. Daquilo que nos interessa especialmente destacar nota-se que a dicotomia real X virtual é mais uma que está sendo desmontada, somando-se à lista anterior. E, sendo assim, prescrições como a que encontramos na abertura do livro "Nomofobia: dependência do computador, internet, redes sociais? Dependência do telefone celular? O impacto das novas tecnologias no cotidiano dos indivíduos. Aspectos: clínico, cognitivo-comportamental, social e ambiental ${ }^{18 "}$ perdem o sentido. "Que o livro sirva de alerta (para) promover a reeducação digital para que possamos resgatar o calor das relações humanas, priorizar a vida real e de fato usufruirmos os benefícios dessas novas tecnologias" (Cavalcanti, 2014, p. xvi) (grifo nosso).

Nicolaci-da-Costa (2006) acredita que estejamos diante de "duas plataformas de vida em permanente interação". Para a autora, pioneira nos estudos sobre os impactos subjetivos da internet, "diferentemente do que muitos temiam nos momentos iniciais de sua difusão, a Internet não criou um mundo paralelo sem conexão com o mundo "real", nem gerou uma realidade "virtual" que

18 Publicado pelo grupo DELETE - Desintoxicação e uso consciente de tecnologi@s do IPUB/UFRJ em 2014. Trata-se do primeiro centro no Brasil especializado exclusivamente no atendimento dos usuários abusivos e dependentes das tecnologias, pioneiros em "Detox Digital". 
substituísse aquela característica do mundo físico. Criou, sim, um espaço alternativo que, embora tendo um relativo grau de independência em relação ao espaço "físico", com ele interage permanentemente". Em tom conclusivo, irá afirmar que "o "virtual" não substituiu o "real" nem o tornou irrelevante. Talvez isso permita que muitos reconciliem o sono!" (Nicolaci-da-Costa, 2006, p. 35).

Almeida e Eugenio (2006) afirmam a mesma ideia com uma expressão diferente e bastante interessante: falam de um hibrido real / virtual. Chegam a tal constatação por observarem que "os jovens dos dias de hoje fundem os domínios do real e do virtual por meio de diversos recursos tecnológicos" (Almeida e Eugenio, 2006, p. 12). Aquilo a que nomeiam de "agenciamentos "reais" $\mathrm{e}$ "virtuais"” organizam-se em esquemas de retroalimentação, incorporam-se uns aos outros, interpenetram-se. "O composto real/virtual, assim em contiguidade, insiste em sua agregação" (p. 58). É curioso notar que o artigo em que apresentam tais ideias foi escrito antes da invenção dos smartphones! As autoras definem as redes sociais existentes à época - Messenger, Orkut e Fotolog - como formas de “ampliação das superfícies de contato" (p. 57).

Partindo de Weissberg (1993) e do que este autor chamou de co-presença constroem sua abordagem sobre o que usualmente entende-se por real e virtual. No uso das ferramentas para a sociabilidade, incluindo aí as tecnológicas, esmaecem-se as descontinuidades entre uma e outra instância, em favor de agenciamentos híbridos, "um misto em que as duas entidades são simultaneamente requisitadas" (Weissberg, 1993, p. 120 apud Almeida e Eugenio, 2006, p. 57). Segundo esta perspectiva a tela se vê dissolvida enquanto fronteira demarcada, já que "conectados permanentemente à internet, transitamos para "dentro da tela" como quem se move por mais um cômodo da casa" (p. 58). Sobre esta percepção de que a tela não mais separa, Leduc (2017) comenta que as telas, do computador ou do smartphone, dão falsamente a ideia de uma separação entre dois lugares, como se houvesse um "lugar internet como espaço físico paralelo àquele da vida real" (Leduc, 2017, p. 03).

Antes de passarmos para outros autores que endossam essa mesma visão gostaríamos de comentar uma das colocações de Almeida e Eugenio neste artigo, a qual nos inquietou. Afirmam que "como o resto da internet, o Orkut é um espelho do mundo real: há de tudo lá, bom e mau, exatamente como aqui fora" (Almeida e Eugenio, 2006, p. 71). Concordamos que coisas boas e más existem 
"lá dentro" das redes sociais virtuais como "aqui fora". Nesse sentido o uso do termo "espelho" se aplica bem. Entretanto, consideramos importante comentar que há diferenças consideráveis entre os modos de se relacionar virtuais e reais. Dizer que não há oposição entre estes domínios, que há interpenetração, não é o mesmo que dizer que não há distinção. A piada contada por Gueller (2017) é ótima para explicitar esse ponto, além de ser muito engraçada: "Estou tentando fazer amigos fora do Facebook. Saio na rua e vou dizendo pra todo mundo o que comi, como me sinto, o que estou fazendo e o que farei mais tarde. Escuto a conversa dos outros e grito "curti”. Até agora, já tenho três pessoas me seguindo: dois policiais e um psiquiatra" (Gueller, 2017, p. 63). É preciso, então, assinalar as diferenças e entender as mudanças.

A concepção de real e virtual pensados como um contínuo se vê reforçada pela percepção de que um registro afeta o outro. Tal ideia é sustentada por autores que concebem a internet como uma ferramenta de veicular as subjetividades de nossa época, mas não só. Para além dessa função, a rede virtual opera também como meio de engendrar as subjetividades, participando ativamente de sua constituição. Segundo Viganò (2009), “o advento da internet contribui potencialmente para fazer da assim dita realidade virtual um elemento constitutivo da realidade social" (Viganò, 2009, p. 245). O filósofo francês Michel Serres produziu diversas obras nas quais procura demonstrar os importantes efeitos do virtual no real, principalmente através da figura dos adolescentes contemporâneos, público em referência ao qual criou o carinhoso apelido de Polegarzinha. Observando-os e dialogando com eles, concluiu que "um novo ser humano nasceu, no curto espaço de tempo que nos separa dos anos 1970. Eles não têm mais o mesmo corpo, a mesma expectativa de vida, não se comunicam mais da mesma maneira, não percebem mais o mesmo mundo, não vivem mais na mesma natureza, não habitam mais o mesmo espaço" (Serres, 2013, p. 20). Entendemos que, se há "um novo ser humano", real e virtual afetam-se radicalmente, o que reforça a impossibilidade de pensá-los em oposição.

Flanzer (2017) aborda esse aspecto enunciando um paradoxo: para alguma coisa ser real ela primeiro tem que ser virtual. $\mathrm{O}$ virtual tem sido anterior ao real e têm imprimido consequências no real (boatos e bullyngs que são disparados na e pela internet e se propagam para além dela exemplificam tal fenômeno). Leduc (2016b) defende que não devemos separar artificialmente o mundo virtual do 
mundo real já que as relações virtuais podem ter prolongamentos na realidade e também consequências importantes. No caso dos adolescentes, por exemplo, os encontros no âmbito virtual funcionam como um modo de laço social suplementar àquele da escola (Leduc, 2016b, p. 01). De fato, tanto em nosso trabalho em uma escola quanto na clínica com adolescentes temos podido constatar que quando postam ou curtem algo na rede, isso repercute em suas vidas, nas salas de aula, nas relações de amizade, nas paqueras. Assim, "são os jovens que experimentam de maneira mais radical hoje que a internet, muito mais que um instrumento de comunicação que conecta emissores à distância (como seria o caso do telefone ou dos correios) se apresenta para nós como um "fenômeno total ${ }^{19}$ " ou totalizante; uma extensão cada vez mais real e opaca de nossa vida, de suas exigências e mesmo de seu sentido" (Costa-Moura, 2014, p. 155).

Pelos mesmos motivos Türcke considera a expressão realidade virtual equivocada. Segundo o filósofo "a presença etérea é uma presença real com um efeito tão poderoso, que é muito fácil esquecer-se, por outro lado, de quão fantasmática ela é" (Türcke, 2010, p. 46). Vale lembrar que para os nativos digitais, que não conheceram nada além de uma vida conectada, essa distinção entre o on-line e o off-line faz ainda menos sentido. Tal público não pensa em sua identidade digital e em sua identidade no espaço real como coisas separadas, ou seja, não pensa em suas vidas híbridas como algo notável (Palfrey e Gasser, 2011, p. 14 apud Melgaço, 2017, p. 69).

A ideia de que um "mundo" interfere no "outro" está presente ainda no argumento de autores como Baym (2010), Castells (2011), Nicolaci-da-Costa (2002) e Sibilia (2015) para quem o real é transformado pelo virtual. Há entre eles o entendimento de que novas tecnologias que vão sendo criadas passam a transformar os sujeitos que as usam, bem como suas práticas. "As subjetividades e os corpos contemporâneos se veem afetados pelas tecnologias da virtualidade" (Sibilia, 2015, p. 65). Dito de outro modo, "essa mesma vida "virtual" atua ainda como uma força transformadora da vida "real"” (Nicolaci-da-Costa, 2006, p. 35). Expressando posicionamentos de Bauman (2001) que fortalecem esse aspecto

\footnotetext{
${ }^{19}$ Expressão de Paul Mathias (2009), autor de Qu'est-ce que l'Internet.
} 
Lima (2017) indica que para o sociólogo o modelo "conexão-desconexão" 20 da internet influencia os relacionamentos sociais dentro e fora do ambiente virtual (grifo nosso). Isso significa que, segundo esse ponto de vista, a internet propicia a frivolidade das comunicações e das formas de se relacionar, ao fazer com que a quantidade passe a se sobrepor à qualidade dos relacionamentos sociais (Lima, 2017, p. 82). "A liquidez e a superficialidade engendram as novas formas de se relacionar no mundo virtual e fora dele" (p. 83).

Essa transformação provocada pela tecnologia digital no mundo e nas subjetividades levou Bentes (2019) a problematizar o termo "cultura digital". Como toda a cultura contemporânea está absolutamente povoada pela digitalidade, a autora sugere que talvez já possamos retirar esse "digital" como adjetivo referido à cultura, concebendo a própria cultura como algo que também se tornou digital. A incorporação do adjetivo "digital" ao substantivo "cultura" reforça a contiguidade entre real e virtual. Nesse ponto, propomos um diálogo entre Bentes e o psicanalista Barros (2015), a partir do texto em que este se dedica a refletir sobre a expressão "mundo virtual". Tomando como ponto de partida a desnaturalização dessa expressão, Barros procura explorar sua própria surpresa diante da ideia de que o virtual possa, ele próprio, constituir um mundo. Frente a essa novidade afirmará, então, que, com a expressão "mundo virtual" o que vemos é uma dissolução mais ou menos rápida da separação entre o mundo e as máquinas. A localização da fronteira entre os dois, que parecia instransponível, já não consegue ser feita com facilidade.

Pouco a pouco vai se fortalecendo a perspectiva de que o ciberespaço como um espaço de socialização se enreda aos outros espaços destinados a este fim. As distinções entre real e virtual, entre online e off-line já não operam mais, ou seja, não dão conta de descrever apropriadamente o mundo em que vivemos. $\mathrm{Na}$ atualidade é preciso estar atentos às interfaces e às sobreposições. Nobre e Moreira (2013) trabalham esse aspecto, lembrando-nos que "ainda que a internet represente, por excelência, o campo do imaterial, para muitos usuários, a socialização ou o sexo virtuais têm o mesmo valor das relações concretas e, como

\footnotetext{
${ }^{20}$ Para a psicanalista Tizio (2007) o modelo dos relacionamentos atuais também está engendrado segundo esse movimento de conexão e desconexão, "quase como se todos vivessem na internet" (p. 85).
} 
tal, são reais, ainda que virtuais" (...) "O virtual abre caminho para aquilo que já possui existência em alguma dimensão" (Nobre e Moreira, 2013, p. 289).

Tisseron (2015) reforça essa ideia traçando um caminho teórico que vai “do virtual psíquico ao virtual digital". O autor argumenta em prol de uma continuidade e de uma não oposição, o que pode ser visto em passagens como esta: "As relações com os objetos digitais de nossas telas são a extensão das relações que mantemos com nosso virtual psíquico, exatamente do mesmo modo que ferramentas mecânicas são a extensão das possibilidades de nossas mãos e a escrita as de nossa memória" (Tisseron, 2015, p. 167). De seu livro "Sonhar, fantasiar, virtualizar" destacamos ainda um dado interessante, que ilustra bem as ideias que estão sendo colocadas neste tópico: "O último relatório do Ministério da Cultura para as práticas culturais dos franceses [2010] mostrou que os que têm mais relações nos espaços virtuais são também os que têm melhor socialização na vida real" (p. 169). Tal fato impulsionou o psicanalista a elaborar a seguinte afirmativa, com a qual concordamos: "as interações pela internet são bem reais, mesmo quando são feitas através de objetos digitais como os avatares" (idem).

A referência a Pierre Lévy é fundamental neste ponto, pois é dele, originalmente, a concepção de que o virtual e o real não são excludentes. Autor chave nas reflexões sobre o tema da virtualidade e do ciberespaço, Lévy, já na epígrafe de sua célebre obra "O que é o virtual” (1996) afirmará, junto a Deleuze, que "o virtual possui uma plena realidade, enquanto virtual” (Lévy, 1996, p. 11). O termo 'virtual', que se origina do latim medieval virtualis e é derivado de virtus significa força, potência. O exemplo a seguir contribui para a compreensão deste sentido: “a árvore está virtualmente presente na semente". Dessa forma, fica desmontada a oposição fácil e enganosa entre real e virtual e o segundo é definido como o que existe em potência e não em ato, o que se opõe, então, ao atual. (p. 15). O esforço de Lévy configura-se como uma tentativa de tirar a conotação de falsidade implícita na acepção que opõe real e virtual.

Ao exprimir-se mais diretamente ao fenômeno computacional, que à época da escrita deste livro já dava largos passos rumo ao que presenciamos hoje, Lévy afirmará que o virtual é uma revolução, por trazer consigo uma alteração radical na forma de conceber o tempo, o espaço, e mesmo os relacionamentos. Vivemos um momento raro em que se anuncia uma cultura nova, sendo "a virtualização um movimento pelo qual se constituiu e continua a se criar nossa espécie" (Lévy, 
1996, p. 147). Segundo o autor, face a este processo de virtualização encontramos os que temem uma desrealização geral e os que veem nas últimas mudanças uma panaceia para os males do mundo. De sua parte, sustenta a proposta de uma terceira possibilidade: “enquanto tal, a virtualização não é nem boa, nem má, nem neutra. Ela se apresenta como movimento mesmo do 'devir outro' do humano. Antes de temê-la, condená-la ou lançar-se às cegas a ela, proponho que se faça o esforço de apreender, de pensar, de compreender em toda a sua amplitude a virtualização" (Lévy, 1996, p. 11/12). Frisando uma vez mais que opor o virtual ao real não nos ajudará a compreender e transitar no novo universo que a nós se apresenta alerta para o fato de que "o virtual, rigorosamente definido, tem somente uma pequena afinidade com o falso, o ilusório ou o imaginário. Trata-se, ao contrário, de um modo de ser fecundo e poderoso, que põe em jogo processos de criação, abre futuros, perfura poços de sentido sob a latitude da presença física imediata" (p. 12). Insistindo nesse viés de evitar o critério do verdadeiro ou do falso Lévy (1996) afirma que, "longe de circunscrever o reino da mentira, o virtual é precisamente o modo de existência de que surgem tanto a verdade como a mentira" (p. 148).

Por fim, gostaríamos de mencionar a contribuição de Mathias (2009) a esta discussão, pelo modo original com o qual se posiciona e dá seguimento às ideias dos autores que trabalhamos até aqui. Partindo de Lévy e visando estabelecer definições para a web, reforça que considerar real e virtual como opostos é um erro, demonstrando que "a internet e a realidade são híbridas e solidárias". Mathias define a internet como um "instrumento que faz mundo" (instrument fait monde), esse instrumento-mundo. Vivemos, pois, sob o "postulado da imersão", já que a informação faz parte de nós, assim como nós fazemos parte dela. Real e virtual se entrelaçam, se confundem.

\subsection{1) A Banda de Moebius como recurso topológico para pensar esse contínuo}

Uma fita de Moebius quebra os nossos hábitos espaciais: direita-esquerda, anverso e reverso, etc. Ela nos faz viver a experiência de um tempo sem limite e de um espaço contínuo.

Lygia Clark, Livro-obra 
Dando continuidade à concepção de que real e virtual estão em um contínuo recorremos agora à figura topológica da banda ou fita de Moebius para seguir nossa exploração. Para abrir esse sub-tópico elegemos esta citação de Lygia Clark, que nos pareceu bastante pertinente, ressoando praticamente como uma das definições possíveis da internet. Nossa proposta aqui é fazer uso dessa estranha forma, desse enigmático objeto com um só lado que fascina matemáticos, artistas, engenheiros e psicanalistas (sobretudo Jacques Lacan $^{21}$ ) para aprofundar as reflexões acerca do "estar online" / "estar off-line". Esse misterioso objeto, que desafia as leis da física e permite "subir para baixo" ou "sair para dentro", se apresentou para nós como um recurso interessante para dar materialidade à dimensão paradoxal característica da internet, trabalhada anteriormente. Inspirados em Lacan, que lançou mão da Banda para, ao invés de nos definir o sujeito, mostrá-lo, procuraremos aqui figurar o continuum real e virtual servindonos deste mesmo objeto.

Inventada em 1858 pelo astrônomo e matemático alemão August Ferdinand Moebius, essa estrutura espacial de superfície infinita permite figurar a impossibilidade de representar o dentro e o fora como espaços antagônicos. É um espaço topológico obtido pela colagem das duas extremidades de uma fita, após se efetuar meia volta em uma delas. Para construí-la, basta pegar uma tira de papel, girar uma de suas pontas e juntar os dois extremos. Assim procedendo temse uma fita com "apenas um lado", que é a característica que define a fita de Moebius. Apesar do efeito de torção gerar a impressão de que ela possui dois lados, na verdade possui um só, sua superfície não se interrompe. Esse objeto de construção simples e efeitos surpreendentes não tem avesso nem direito, seu avesso e seu direito são contínuos. Sendo assim, a diferença entre as duas faces é uma questão de tempo e de espaço.

Uma das características mais fascinantes da fita de Moebius é ser o que os matemáticos chamam de "objeto não orientável". Isso significa que é impossível determinar qual é a parte de cima e qual é a parte de baixo, o que é o dentro, o que

\footnotetext{
${ }^{21}$ Lacan encontrou na banda de Moebius um importante recurso para interpretar a estrutura do aparelho psíquico, utilizando-a como metáfora para o funcionamento do psiquismo humano. Em sua obra encontramos também articulações entre a Banda de Moebius e alguns conceitos psicanalíticos como: o eu freudiano; a relação significante/significado; a relação entre sujeito e objeto $a$; o corte; a repetição. A banda de Moebius foi definida pelo psicanalista francês como "o suporte estrutural do sujeito como divisível".
} 
é o fora. Se, por exemplo, você começasse a caminhar pela parte de "cima" de uma fita de Möbius, quando desse a volta completa e chegasse novamente ao ponto de partida, estaria, sem se dar conta, parado na parte de "baixo". Da mesma forma, se começasse a caminhar pela borda externa da fita, ao dar a volta completa, terminaria em sua borda interna. Tal lógica não poderia facilmente ser transposta para as reflexões acerca da cultura digital? Cremos que sim e tentaremos, através de dois exemplos "reais" (ou serão virtuais?!) demonstrar essa impossibilidade de determinação exata de uma ou outra parte (realidade ou virtualidade).

Lançado em julho de 2016 nos Estados Unidos o jogo Pokémon Go é paradigmático para testemunhar o hiper atravessamento da vida cotidiana pela tecnologia, protagonizando de forma emblemática a dissolução entre real e virtual que por ora nos ocupa. Sucesso absoluto que atraiu milhões de adeptos em todos os países em que foi lançado trata-se de um jogo revolucionário por usar a realidade aumentada, isto é, a mistura da realidade e do virtual. A novidade introduzida por este aplicativo é a junção do mundo dos videogames à nossa realidade habitual, criando uma terceira dimensão. Tendo como objetivo capturar pequenos monstrinhos orientais espalhados pelas ruas da cidade, os jogadores caminham com seus celulares à mão, lançando pokebols e aumentando suas pontuações. Como efeitos reais da brincadeira virtual, citamos dois fenômenos tão comuns quanto intrigantes: de um lado, o aumento de acidentes e ferimentos envolvendo jogadores, motoristas ou outros pedestres. De outro, a formação de novos grupos que se encontram em pontos específicos das cidades onde se concentram pokémons raros e, porque não, jovens excêntricos em busca de novos laços. Esse novo meio de construir amizades talvez ilustre o comentário de Lima (2017) em que afirma que "a virtualidade do ambiente on-line se enoda à realidade off-line, numa articulação que pode favorecer o laço social" (Lima, 2017, p. 84).

Sobre essa "febre" que foi o Pokémon Go, a jornalista Maria Ribeiro compartilhou o seguinte comentário em sua coluna no Jornal O Globo: "Tem gente que busca a iluminação, gente que espera o grande amor, e gente que caça pokémons" (...) se a vida não tem sentido, bora ir mesmo assim. (...) Esperando Godot e procurando pokémons, a gente vai. Go, companheiras, go. (...) O Japão traz dessa vez uma busca por alguma coisa absolutamente abstrata e irreal, mas 
que de vez em quando pode ter uma paisagem bonita. Go, Pokémon, go" (Ribeiro, 2016).

O segundo exemplo que escolhemos para dar corpo a essa proposta de pensar a cultura digital através da Banda de Moebius é o fenômeno virtual Hatsune Miku, a cantora japonesa de assombroso sucesso na atualidade. Ela nasceu com 16 anos, 1 metro e $58 \mathrm{~cm}$ e $43 \mathrm{~kg}$, dados que permanecerão inalterados para sempre. Essa artista virtual, cuja voz é um programa eletrônico, faz concertos "ao vivo", em várias cidades do mundo e convoca um mercado adolescente que esgota as entradas, pagando milhões de dólares por elas. Além de frequentarem seus shows, seus fãs a seguem pelo Facebook, lhe enviam mensagens, dando-lhe existência e promovendo, por conseguinte, o efeito considerável que produz. Impressionada com essa possibilidade inédita a psicanalista Favret (2016) escreveu um artigo a respeito de Miku, do qual extraímos duas passagens: a fala de uma fã e o comentário da autora a respeito deste fenômeno. Para a adolescente entrevistada "é genial a sensação de ficar fascinada por algo que não é real. Essa é a sensação mais genial, e não é absurda, porque às vezes a realidade fede!". Favret acredita que justamente por Miku não ser a imagem virtual de um corpo encarnado é que ela tem tamanha importância: sempre estará disponível, não haverá cancelamento de concertos por uma afonia, nem por mal estar advindo de algum outro sintoma e jamais envelhecerá (Favret, 2016).

Pokémon Go, Hatsune Miku e tantos outros elementos e hábitos da cultura contemporânea nos fazem perceber o que, topologicamente, a banda de Moebius consegue representar: uma subversão em nosso espaço comum de representação, que indiferencia as oposições, colocando direito e avesso em continuidade. $\mathrm{Na}$ banda (assim como no mundo digitalizado da Era da internet) interior e exterior / real e virtual se inespecificam.

Vale acrescentar ainda um breve comentário sobre o filme francês "Quem você pensa que sou?" (2019), do diretor Safy Nebbou, pela forma interessante e sensível com a qual consegue abordar essa temática dos mundos real e virtual como espaços contínuos. A trama, protagonizada por Juliette Binoche no papel da cinquentona Claire, explora justamente os efeitos reais de experiências online, problematizando as noções de identidade e de verdadeiro e falso. Depois de ser abandonada pelo marido e de tentar um relacionamento "real" com um jovem 
rapaz que também não prosseguiu, Claire decidiu criar um perfil com outro nome (Clara), outra idade (24 anos), outra foto (de uma jovem exuberante): um perfil falso. A mensagem transmitida por esta obra que mais nos impactou pode ser resumida da seguinte forma: mulher destruída no campo amoroso usa a ficção como tentativa de cura. No fim do filme, assistimos Claire dizendo à analista: "eu precisava ser cuidada mesmo que com ilusões". Outras de suas falas emblemáticas à terapeuta, ricas para refletirmos sobre nosso tema de pesquisa, seguem adiante: "As redes sociais são tanto a salvação quanto a perdição"; "Um dia você é caça, no outro é caçador"; "aquela bolinha verde que indica que o outro está online traz muito conforto. O efeito é semelhante ao salbutamol, faz respirar melhor"; "aquilo era excitante, a espiral começou"; "Era eu de verdade"; "Ele gostou da minha voz, das minhas palavras"; "Quando estava com ele me sentia viva. Eu tinha 24 anos, não estava fingindo. Nunca me senti tão viva"; "Algo está acontecendo entre a gente. Conheci alguém; tudo sempre divertido; estou me liberando do meu ex". O uso da rede social nesse processo que envolvia tanto a elaboração do luto da separação quanto sua reconstrução enquanto mulher lhe pareceu positivo, vivificante. Podendo contar com o trabalho analítico para se haver com intensos efeitos dessa nova experiência, Claire foi chegando a conclusões tais como essas: "Me senti mais Clara do que Claire"; "Viver outra vida? Não, a minha, enfim". Finalizamos, portanto, essa seção sobre real e virtual enquanto registros em continuidade com essa imagem de Claire e Clara se misturando, ou seja, de uma outra Claire, diferente da anterior, pelo fato de "ter sido", também, Clara.

\section{7) Os psicanalistas frente aos laços virtuais: posicionamentos em curso}

O estado líquido da civilização é ao mesmo tempo um caldo que admite o cultivo de formas alternativas de ser, de amar e de desfrutar.

Dessal (Bauman; Dessal, 2017, p. 10).

Caminhando para o encerramento deste capítulo e prestes a darmos início à discussão mais diretamente ligada à solidão e ao laço com o outro em tempos de conectividade traremos agora mais uma gama de reflexões que vêm sendo feitas por psicanalistas pelo mundo afora, reflexões afinadas com os pontos que buscamos sustentar ao longo destas páginas iniciais. Desejamos assim prosseguir 
em um de nossos objetivos de pesquisa - o de mapeamento do campo de estudos em que agora nos inserimos - além de ressaltar os pressupostos éticos e teóricos que nos norteiam na escrita deste trabalho.

"O que estamos fazendo da tecnologia e como isso está nos transformando?” (Pelúcio, 2017, apud Miskolci, 2017, p. 16). Para essa pergunta, muito bem construída, a autora oferece uma resposta igualmente pertinente: "A resposta não é direta, nem sintética. Nem poderia ser. Nunca é simples falar da vida emocional" (idem). A autora fortalece aqui o argumento com o qual concordamos de que não estamos diante de um fenômeno simples, e que, portanto, não podemos tirar conclusões rápidas e gerais a seu respeito.

Mas será que todos os autores que optam por posicionamentos que tendem a ir pelo caminho oposto, ou seja, que parecem ignorar as complexidades, generalizando ou exagerando na direção dos malefícios provocados pela internet, realmente têm uma visão polarizada e simplória da coisa? Acreditamos que não. Ao irmos nos aproximando do final da pesquisa, já conhecendo um pouco mais as discussões deste campo, observamos que alguns autores (psicanalistas e de áreas afins) adotam esse tom que soa pessimista como um grito de alerta ${ }^{22}$. Enfatizam o lado prejudicial para acordar a sociedade anestesiada e robotizada, pouco consciente dos novos hábitos que passou a adquirir e repetir. Assim, optam por considerar as vantagens e benefícios das novas tecnologias da comunicação como pontos pacíficos, inquestionáveis, que não precisam sequer ser explorados. Rumam diretamente para as críticas negativas, sublinhando o que os preocupa no novo cenário, sem que queiram, necessariamente, que voltemos no tempo. Não seriam ingênuos a esse ponto. Essa é então uma terceira via de abordagem do tema, a qual respeitamos, mas com a qual não nos alinhamos.

Desde nosso ponto de vista, a internet é uma novidade que veio pra ficar e que produziu, de fato, uma nova dinâmica social. É inegável que as mutações introduzidas em nossas vidas trazem consequências e é claro que há razões para nos preocuparmos, já que certas mudanças realmente assustam, nos alarmam. Ainda assim, mesmo que a preocupação seja legítima e que tenha o seu lugar nos

${ }^{22}$ O livro "Alone Togheter", de Sherry Turkle, nos parece um bom exemplo disso. Num dado momento de sua exposição a pesquisadora formula uma instigante questão - "devemos nos perguntar quando uma tecnologia expande nossas capacidades e possibilidades ou explora nossas vulnerabilidades?" - para, em seguida, afirmar que em relação a internet não devemos mais perguntar isso, pois já está claro que é algo danoso como o foi "Coke and a burguer" (Turkle, 2017a, p. xxii). 
discursos que estão sendo produzidos sobre nossa época, não é por essa via que desejamos caminhar em nossa pesquisa. Acreditamos que temos mais a contribuir para esse campo de estudos, para os psicanalistas praticantes e para a sociedade, com o enfoque que construímos, o qual preconiza a tensão, a manutenção do ar de espanto frente aos fenômenos, ou seja, um enfoque que se nutre do estranhamento visando provocar reflexões. A conclusão que nos transmite Goldenberg (2017) em um de seus ensaios serve para ressaltar de onde falamos: "Tudo mudou, o que não me parece um problema, desde que seja pensado. (...) Não é que nada se perdeu. Algumas coisas se perderam... Ganhamos outras" (Goldenberg, 2017, p. 87).

Laurent é mais um psicanalista da atualidade que se posiciona frente à rede como algo que "nós fazemos com, entre aceitações e recusas" (Laurent, 2017, p. 18). Dialogando com colegas psicanalistas, faz questão de adverti-los de que "há ditos que têm incidência, mesmo que transportados pela internet" (idem). Prosseguindo em suas reflexões a respeito das novidades advindas com a net traça uma espécie de paralelo entre o sexo virtual e o feito "em carne e osso", aludindo ao mito grego de Charybdis e Scylla ${ }^{23}$ justamente para salientar que em nenhum dos dois estamos livres de adversidades. "Navegamos entre os dois monstros, então, tenhamos serenidade!" (ibidem).

Pfauwadel (2017) insere-se nessa discussão adotando uma posição consonante com as anteriores. Acredita que "seja lá o que for, o que os psicanalistas têm a fazer é jogar a partida com esse real da internet e repensar a ética da psicanálise na era digital" (Pfauwadel, 2017, p. 06). Igualmente antenado com os novos desafios para os quais o mundo contemporâneo nos convoca Lyra (2018) escreve sobre a exigência de que nos interessemos de forma mais profunda pela vida digital de nossos analisantes. Isso porque, como nos ensina Laurent (2017), a internet "fornece um campo de interpretações renovadas do enigma a ser decifrado", tratando-se de "um novo meio para tecermos e mantermos os laços sociais", um lugar para onde "cada um transporta sua solidão". "É inimaginável estar privado dela, é um novo direito que se acrescentou a cada um de nós", acrescenta (Laurent, 2017, p. 12). Esse direito adotado por todos de forma imediata demanda reflexão, pois, como demarca Dessal (2017b) “a velocidade no

\footnotetext{
${ }^{23}$ Expressão usada para falar que estamos entre duas coisas difíceis, tendo que escolher entre dois males. Trata-se de dois monstros marinhos da mitologia grega.
} 
usar se antecipa ao tempo que a subjetividade precisa para sua compreensão" (Dessal, 2017b, p. 11).

Enaltecendo justamente o quão rico pode ser para um psicanalista deter-se com curiosidade sobre os assuntos ligados à web, Leduc (2017) afirma que podemos encontrar através da internet toda uma clínica em estado selvagem, muito informativa sobre os nossos tempos. Sendo assim, é um lugar privilegiado de observação dos impasses sintomáticos de nossa civilização, um lugar ao qual recorrer para ter notícias de uma "psicopatologia da vida digital cotidiana". Sua posição está em consonância com a orientação de Laurent, quando este afirma que "Eros e Thanatos encontraram um novo campo de manifestação" (Laurent, 2017, p. 17). Esta psicanalista propõe então (através da criação de uma simpática expressão) que nos aventuremos em uma "clínica da rede", que visaria interrogarmo-nos sobre os usos que estão sendo feitos, os modos de gozo veiculados na rede (Leduc, 2017, p. 01). O interesse dos psicanalistas por esse fenômeno dá provas de que não ignoramos os fatos nem o dia-a-dia da cultura, ou seja, de que seguimos alinhados aos pressupostos tecidos por Freud na origem da psicanálise.

Em um cenário em que surgem cada vez mais iniciativas como as do grupo DELETE (IPUB / UFRJ), que se propõem a oferecer “orientação, informação, noções de etiqueta digital e dicas para um uso consciente das tecnologias" (King, Nardi, Cardoso, 2014, p. xix) o que a psicanálise tem de específico e diferencial a oferecer? Acreditamos que a resposta a este desafio ainda esteja em construção. Mas, desde já, podemos afirmar que o exercício de observar, de estar a par, de escutar os "tropeços $e$ soluções contemporâneas ${ }^{24 "}$ frente aos desafios da vida, nos quais se imiscuíram de uns anos para cá a internet e seus dispositivos é algo que nos cabe e que, bem orientados, podemos fazer. Paralelamente às clínicas de desintoxicação digital (ou detox) que estão sendo criadas e obtendo cada vez mais procura - seja para tratamento ambulatorial, seja para internações - o dispositivo psicanalítico se presta a um trabalho de desintoxicação de outra ordem, como nos esclarece Laurent (2017): Convivemos hoje com uma overdose de saberes, de companhias e de conexão. Nesse ambiente, a psicanálise permite a desintoxicação,

\footnotetext{
${ }^{24}$ Expressão utilizada no título de uma das mesas da V Jornadas Clínicas SEPAI, nomeada: "Do sexo à sexualidade: tropeços e soluções contemporâneas". Na ocasião tivemos a oportunidade de apresentar um trabalho relacionado a essa pesquisa de doutorado.
} 
é uma iniciativa de utilidade pública. A escuta particularizada permite ouvir novamente os significantes sozinhos que atravessam a atmosfera do ruído-internet (Laurent, 2017).

Em entrevista à revista Veja em março de 2017 o CEO do Google, Sundar Pichai, transmite animadamente as ambições futuras da gigante empresa em que trabalha. Otimista por estarmos "rumo a uma Terra on-line" propagandeia a facilidade de nos comunicarmos e o quanto a indústria da computação pessoal facilita a vida dos seres humanos. "Quanto mais avançamos, mais somos capazes de conectar usuários com quem importa para eles, de ajudá-los a ser produtivos, de auxiliá-los a ser felizes". "A meta principal é melhorar ${ }^{25}$ a vida dos usuários". Sendo esse tipo de discurso frente às inovações predominante em nossa sociedade, vemos como um importante dever político e ético dos psicanalistas fazer circular outro tipo de discurso, na contramão deste. Por partimos do entendimento de que "a aventura humana é um fabuloso compêndio de façanhas e tragédias" (Dessal, 2017 b, p. 13) não aderimos prontamente a promessas em tom de deslumbramento como essa. "Atentos ao que cai, ao que se exclui, ao que fraqueja, tropeça, estremece, escapole ou incomoda o discurso triunfante da razão ilustrada" (idem) é assim que exercemos nossa prática.

Se há algum otimismo ou visão positiva por parte de nós analistas, tal postura não se nutre da possibilidade de vivermos uma vida mais fácil graças à tecnologia. Nesse ponto, concordamos com Dessal, quando diz o seguinte: "Como em qualquer outra esfera do humano, sempre tropeçaremos com o sintoma, com o que não funciona. E será precisamente aí, nisso que não caminha como os algoritmos previram, onde o mais propriamente humano seguirá resistindo. Se nós psicanalistas podemos trazer alguma visão positiva com relação ao futuro é que sempre haverá algo que não funciona, mesmo que isso possa soar estranho. Enquanto isso continuar acontecendo, enquanto algo de nós se negar à automatização e à completa absorção da existência na economia do cálculo e da programação, podemos confiar que permaneceremos vivos" (Dessal, 2017b, p. $15)$.

Enfim, diante da multiplicação exponencial das telas, do entusiasmo, do catastrofismo e do espanto delas decorrente, resta-nos indagar "o que fazer com

\footnotetext{
${ }^{25}$ Tal ideia aparece também em um comercial da Apple de 2018 cuja manchete é: "A vida é mais
} fácil no iPhone". 
isso?". Estudar, debater, escutar e escrever algo a respeito nos pareceu uma das respostas possíveis, um caminho estimulante a ser trilhado. Entendemos que subjetividades em movimento convocam a práticas renovadas e que, portanto, há muitas maneiras de se estar no mundo digital, muitas maneiras de usar o celular, muitas maneiras de fazer uso da internet para lidar com a solidão e para estabelecer laços. Se essa é uma tecnologia que se tornou uma realidade em nossas vidas, abrir mão dos inúmeros benefícios que nos trazem por conta dos malefícios que podem estar a ela atrelados nos parece empobrecedor. Combatê-las com radicalidade obscureceria nossa visão de futuro e obstacularizaria nossa reflexão a respeito do tema. Como bem coloca Laurent (2014) "não há nenhuma razão para sermos tecnofóbicos" porque "nós (psicanalistas) também podemos utilizar as máquinas, para, no entanto, instalar um outro discurso" (Laurent, 2014, p. 44).

Assim, para terminar, destacamos um parágrafo de Kaufmanner na revista CULT de outubro de 2019, em que versa sobre psicanálise e invenção, seguido de uma provocação nossa: "É nesse espaço onde reina sua precariedade que o humano inventa um mundo, vive sua diferença, constrói sua singularidade e seu gosto pela vida. Ali ele inventa seu tratamento único para o mal-estar que sua condição humana instala. Assim, a vida para o humano é acima de tudo uma invenção, um fio tecido a partir da linguagem e seus efeitos sobre o corpo, uma produção de sentido absolutamente singular a cada ser falante" (Kaufmanner, 2019, p. 36). Reflitamos, pois, a fim de incluir a internet em nossas invenções de mundo, em nossas produções de sentido, em nossas sociabilidades, em nossas vidas, enfim. 


\section{CAPÍTULO 2 \\ A SOLIDÃO E O LAÇO COM O OUTRO \\ A PARTIR DE FREUD E DE LACAN}

O presente capítulo tem como objetivo fundamentar conceitualmente, a partir da psicanálise, as duas temáticas que escolhemos explorar dentro do vasto campo de estudos sobre a internet e seus impactos subjetivos: a solidão e o laço com o outro. Conforme apresentamos na introdução, desenvolveremos aqui algumas noções trabalhadas por Freud e por Lacan que acreditamos serem ricas para a reflexão a qual nos propomos nessa tese. Esclarecer de antemão de que pressupostos partimos para pensar a condição da existência humana e o campo dos relacionamentos certamente ajudará o leitor a nos acompanhar nas reflexões que faremos no capítulo seguinte, referentes à solidão e ao laço com o outro na Era da Internet.

Nossa proposta é, portanto, oferecer aos leitores essa base sólida de conhecimento, para que possam, assim como nós, se servir desses ensinamentos como chave de leitura dos fenômenos da atualidade. Se é certo que o psicanalista não escuta o homem em massa, mas sim um a um, ele não pode em contrapartida se furtar à uma compreensão do homem de sua época (Fuks, 2020). Como salienta Dessal (2017) “a psicanálise pode - e deve - ser considerada um procedimento de leitura" (Bauman; Dessal, 2017, p. 74). Diante das inquietações que a hiperconexão nos suscita, recorrer a Freud e a Lacan pode iluminar possíveis caminhos de pensamento, impulsionando a construção de algumas articulações entre o que os autores propõem em sua época e os acontecimentos de nossos dias. Assim sendo, nossa tarefa agora é lançarmo-nos a um retorno a Freud e a Lacan em busca de ferramentas conceituais que colaborem com a discussão acerca da rede e dos internautas que nela navegam, acerca, pois, dos efeitos dessa novidade tecnológica nas experiências de cada um ao lidar consigo mesmo e com o outro.

Desejamos deixar claro que nosso ponto de partida está calcado na pressuposição de que "a psicanálise não pode ser excluída de nenhum fenômeno do qual o ser humano faça parte" (Bauman; Dessal, 2017, p. 50). E - disso ninguém poderá discordar - o fenômeno da interação via redes virtuais engloba grande parte dos seres humanos, em abrangência e em profundidade. Muitos acessam as redes e este acesso em muito impacta diversos sujeitos. Apesar de 
nesse capítulo fazermos apenas algumas menções à articulação com a internet, acreditamos que o material didático exposto já tem, em si, a potência de ajudar o leitor em suas próprias reflexões acerca do tema. É esse, ao menos, o nosso convite, o de nos acompanhar nesse desafiador exercício de refletir sobre seu próprio tempo. Evidentemente, as ideias aqui trabalhadas dialogarão com as do restante da tese, nos momentos em que nos dedicarmos à construção de pontes entre elas e as questões mais diretamente ligadas à Era digital.

Ancorados em Freud, partimos da premissa de que a psicanálise pode trazer uma imensa contribuição para a compreensão dos fenômenos sociais. Em "Psicologia das Massas e análise do eu" (1921) o autor procura esclarecer o que faz a psicanálise se interessar pelo coletivo em busca de entender o indivíduo. É um texto rico para aprendermos sobre o porquê de os fenômenos sociais terem interessado a Freud e seguirem interessando aos psicanalistas. Segundo Freud, a psicologia individual raramente pode abstrair-se das relações do ser humano particular com os outros indivíduos. "Na vida psíquica do ser individual, o Outro é via de regra considerado enquanto modelo, objeto, auxiliador e adversário, e, portanto, a psicologia individual é também, desde o início, psicologia social, num sentido ampliado, mas inteiramente justificado" (Freud, 1921/2011, p. 14). Argumentos como estes justificam a entrada da psicanálise como mais um dos campos de saber que pode vir a contribuir para as reflexões acerca da sociedade hiperconectada em que vivemos.

\section{1) Solidão em tempos de conexão}

Uma charge que circulou nas redes sociais em 2015 nos chamou a atenção: em seu consultório, um psicanalista escuta o paciente deitado no divã, chorando ao relatar suas mazelas por ter "zero amigos, zero notificações e zero mensagens no Facebook". Podemos interpretar a charge pensando na procura por um analista para falar da solidão, em tempos de conexão?

Em 2018, já absolutamente envolvidos com essa pesquisa, fomos impactados com a notícia sobre a recente criação de um Ministério da Solidão na Inglaterra. Uma matéria do jornal "El País" divulgou essa inusitada informação, de que o governo da primeira ministra britânica Theresa May criou o chamado Ministério da Solidão, destinado a combater um problema social que afeta um 
número alarmante de nove milhões de pessoas no país. Com o título "Reino Unido cria secretaria de Estado contra "epidemia" de solidão", vemos a solidão passando a ser vista, ao menos nesse cenário, como um mal contemporâneo, uma verdadeira epidemia, tendo se tornado uma questão de Estado, um assunto de saúde pública. A criação de uma secretaria própria no Governo focada a tratar da solidão dos habitantes calca-se em conclusões como estas: ficar só pode ser tão prejudicial à saúde quanto fumar 15 cigarros por dia. Segundo a deputada trabalhista Reeves, presidenta da comissão, "nas últimas décadas, a solidão passou de desgraça pessoal à epidemia social". E complementa: "Cada vez mais pessoas vivem sozinhas. Às vezes parece que o nosso melhor amigo é o celular". Uma vez mais uma vivência cotidiana nos inquietou, relançando-nos com ainda mais curiosidade nesse exercício de se perguntar sobre a solidão na era da comunicação.

A charge e a matéria de jornal - assim como inúmeras outras publicações na mídia ou mesmo no âmbito acadêmico - apontam para um possível paradoxo, que exploraremos adiante: há alguma proporção entre conectividade e solidão? Quanto mais conectados, menos solitários? Quanto mais recursos para nos comunicarmos com o outro, menor nossa sensação de estarmos sós? Atentos à armadilha de cairmos em polarizações que investigações como esta podem nos levar, procuraremos trabalhar os fenômenos da solidão e da conexão em suas complexidades, afastando-nos das abordagens que os veem em polos opostos. Para tal, recorreremos às enunciações de Freud e de Lacan em torno das temáticas da "solidão" e do "laço com o outro", pois, a nosso ver, contribuem para uma visão mais rica e interessante. Eis o nosso desafio.

Veremos, justamente, que segundo a abordagem psicanalítica dos fenômenos humanos, essas são temáticas em continuidade e que, portanto, não estão em oposição. "Solidão" e "laço com o outro" não são opostos perfeitos. E, assim sendo, preferimos nos posicionar nesse campo de investigação com perguntas como essas: de que forma essas novas modalidades de comunicação repercutem nas subjetividades de nossa época? Qual o papel da internet nos modos singulares de o sujeito habitar a solidão? De que forma o saber psicanalítico sobre o humano e sobre a constituição do laço social pode embasar uma reflexão acerca dos vínculos entre pessoas e entre pessoas e máquinas na Era da internet? Como pensar, a partir desse referencial teórico, as repercussões da existência desses novos tipos de dispositivos nas relações interpessoais? Nosso 
foco é observar as mudanças ocorridas no âmbito das interações e refletir sobre o alcance da tecnologia aplicada à comunicação nas subjetividades contemporâneas. As diferenças daí decorrentes chegam a alterar profundamente o homem em sua lida consigo mesmo e nos laços que estabelece com os outros?

Com relação à solidão, partimos do princípio de que é uma experiência multifacetada, repleta de sensações paradoxais e ambiguidades. Veremos autores abordando a "boa" ou a "má" solidão, poetas compondo a partir de uma "solidão a dois", pesquisadores da atualidade ponderando sobre isolamento e/ou tentativas de socialização via redes sociais. Para além de uma experiência repleta de nuances é um termo de difícil definição, pois pode ser usado tanto com o sentido de "estar sozinho", sendo quase um sinônimo de isolamento, quanto referido a uma dimensão mais existencial, abstrata, estado inalterado mesmo junto à companhia de alguém. Logo se vê que se trata de um terreno espinhoso para quem se arrisca a trabalhá-lo no formato didático exigido por uma tese de Doutorado. Entretanto, tão espinhoso quanto interessante e atual, razão suficiente para o perseguirmos, sempre atentos ao esforço de situar o leitor a respeito do recorte que nos propomos a fazer. Intrigados com o frisson causado pela hiperconexão, retornamos, pois, a Freud e a Lacan, em busca de uma base de conhecimentos psicanalíticos que possam nos ajudar a compreender tal fenômeno, a nos situar diante dele, para, enfim, seguirmos atuando como psicanalistas na era da Internet.

\section{2) A solidão estrutural}

A solidão, a mesma que existe em cada um me faz inventar. E haverá outro modo de salvar-se? Senão o de criar as próprias realidades?

Clarice Lispector, Um Sopro de Vida

Inicialmente, é preciso destacar que a solidão não é propriamente um conceito da psicanálise. Como lê-la desde Freud e Lacan, se a seu respeito não existem ensaios e conferências de Freud, nem tampouco escritos ou seminários de Lacan? De fato, a solidão não foi tomada como objeto de estudo e teorização por estes autores como fora, por exemplo, a repetição, o inconsciente, a pulsão ou a angústia. Todavia, encontramos nas obras de Freud e de Lacan diversos aspectos vinculados a essa temática, o que nos leva a afirmar que, em sua abordagem da 
condição humana, a psicanálise apresenta noções fundamentais para a compreensão da vastidão polissêmica da palavra solidão. Optamos por organizar as ideias que desejamos desenvolver nesse capítulo da seguinte forma: primeiramente traremos as colocações de psicanalistas que abordaram diretamente o tema da solidão. Nas passagens destes autores veremos diversas menções a noções freudianas e lacanianas, às quais só nos dedicaremos de forma aprofundada em um segundo momento.

Sobre a pertinência de recorrermos à psicanálise para pensar a solidão, Azevedo (2007) aponta que "na obra freudiana, apesar de não encontrarmos considerações especificamente tratando do tema da solidão, temos importantes pistas para refletirmos sobre ele" (Azevedo, 2007, p. 225). Audibert (2008) posiciona-se de modo semelhante, defendendo que, "apesar da solidão ser um tema mais diretamente ligado à literatura, à filosofia ou à sociologia do que à psicanálise, Freud realizou um esboço da solidão através de outros conceitos" (Audibert, 2008, p. 15). Ao longo deste capítulo apresentaremos os conceitos que elegemos, em Freud e em Lacan, os quais acreditamos serem os mais fecundos para pensarmos sobre a solidão segundo um viés psicanalítico.

Com Freud, aprendemos que a solidão está relacionada ao desamparo inextinguível. É algo que diz respeito ao incurável da experiência humana, à sua dimensão trágica. Nas palavras de Dessal (2017), tem a ver com a "precariedade da condição humana: nossa falta original de fundamento, de identidade e até de sentido" (Bauman; Dessal, 2017, p. 118). Refletindo sobre o tema a partir de Freud e de Lacan, Alvarenga (1997) propõe que tomemos "a solidão enquanto forma do desencontro", ao partir da "hipótese de que o desencontro é estrutural (pois) não há relação sexual” (Alvarenga, 1997, p. 10).

Nessa mesma linha de pensamento, Audibert (2008) localiza a solidão enquanto "originária, fundamental, essencial, universal e inexorável. Apesar de toda a empatia que nosso entorno possa manifestar, experimentamos sós o nascimento, a velhice, sentimentos bons ou ruins, emoções, dores do corpo quando este sofre, lutos, e a perspectiva, serena ou angustiante, da própria morte, certeza absoluta de nossa solidão, horizonte incontornável do destino humano" (Audibert, 2008, p. 13). A psicanalista francesa define a solidão como "vestígio da prematuração do pequeno homem, que faz dele um ser absolutamente dependente de seu ambiente ao nascer, substancialmente unido ao mundo por suas 
necessidades, já que é totalmente vulnerável” (p. 14). Sublinha o fato de que "o traço dessa dependência vital segue nos impelindo a estar com outros a nosso redor, outros em relação a quem temos a necessidade de sermos compreendidos, amados e protegidos. Cada um deve então encontrar desde a mais tenra idade seus pequenos ou grandes arranjos face a seu être-seul ${ }^{1}$ (ser-sozinho), à medida em que irão ocorrendo os eventos da vida" (idem). Deixaremos apenas indicada, a partir desse ponto, nossa intenção de pensar a internet - ou, mais propriamente, o uso que cada sujeito faz dela - enquanto parte de um possível arranjo face a essa condição do ser falante enquanto être-seul.

Estamos diante de uma concepção da solidão enquanto originária, isto é, condição que estaria na origem - lógica e cronológica - da vida humana. A solidão desamparada do bebê desde o nascimento estará, em algum nível, sempre presente. É o que propõe Freud ao pensar o desamparo como insuperável. A solidão de cada um corresponde a uma posição estrutural, isto é, há uma solidão que é de estrutura. Desse modo, para a psicanálise, a constituição do sujeito é perpassada pela solidão. Segundo Carneiro (2007), esse sentimento, experimentado lado a lado à angústia do nascimento, acompanhará o sujeito, levando-o a buscar sempre uma suposta unidade perdida (que sabemos ser mítica, pois, segundo Freud e Lacan o bebê é um ser fragmentário). Existem caminhos e descaminhos que o sujeito pode tomar para administrar sua solidão singular: "Tornando seu mundo mais povoado de boas experiências, não se sente tão só" (Carneiro, 2007, p. 22); "Na luta pela sobrevivência, luta pela vida, os recursos são parcos" (p. 24). Será que podemos pensar a internet como um recurso a mais nessa luta, novidade que veio se somar a outros recursos anteriormente existentes? O uso da comunicação digital pode ser interpretado como um dos caminhos possíveis para administrar a solidão singular? Aprofundaremos essa reflexão no próximo capítulo, em que abordaremos especificamente essa questão.

Com relação ao que Freud descreve no "Projeto para uma psicologia científica" (1895), a autora propõe a seguinte releitura: "O momento inicial da vida de um ser humano é marcado por uma cratera, de onde emanará um sentimento que o acompanhará por toda a sua existência: o sentimento da solidão"

\footnotetext{
${ }^{1}$ Optamos por manter esse termo em francês, língua original de Audibert, já que porta uma riqueza semântica intraduzível para o português. As demais citações da autora foram livremente traduzidas por nós.
} 
(Carneiro, 2007, p. 24). Vemos sublinhada uma dimensão da solidão que permanece enquanto tal, aspecto fundamental para a compreensão do que Freud postulará num momento posterior de sua obra.

Ferrari (2008) trabalha a solidão como afeto inerente ao processo de subjetivação, introduzindo o par 'solidão-pulsão' para pensar a respeito do tema. Concebendo a solidão enquanto inaugural, articula-a à inexistência de um objeto com o qual a pulsão se encaixe. A autora nos apresenta, portanto, a ideia de que o desencaixe sempre existente entre a pulsão e os objetos remeterá o sujeito humano à sua dimensão solitária, a qual não tem como ser recoberta por nenhum objeto. Em seguida, Ferrari articulará a dimensão pulsional aos vínculos sociais que estabelecemos, afirmando o seguinte: "Freud e Lacan sempre se preocuparam com os vínculos que os sujeitos estabelecem. Em ambos se observa claramente a preocupação com o social, até mesmo porque se depararam com uma solidão inerente à constituição subjetiva própria a uma verdade que só diz respeito às pulsões do sujeito" (Ferrari, 2008, p. 18). Ainda referindo-se a estes dois autores Ferrari afirma que ambos "ensinaram que, se há essa solidão estrutural dos sujeitos, se essa verdade os caracteriza e os faz funcionar de modo singular, tal condição é que lhes possibilita formas de estabelecimento de laços sociais" (idem).

É interessante notar que as colocações da autora trazem à cena o aspecto que mencionamos anteriormente, da não oposição entre solidão e laço. É por sermos incompletos e por não encontrarmos nenhum objeto que se encaixe perfeitamente em nós que buscamos vínculos com os outros. Ou seja, a solidão é um dos solos que nutre nossos anseios por fazer vínculos. O trecho que se segue reforça uma vez mais tal ideia de articulação entre ambos que desejamos sustentar: "Nas obras de Freud e Lacan sempre esteve presente a preocupação com os laços sociais, com as formas que os sujeitos encontram para viverem juntos, já que há uma solidão inerente à constituição subjetiva” (ibidem).

Lyra (2019c) reforça esta inter-relação entre solidão e laço ao salientar que na abordagem da solidão a partir da psicanálise, "não nos cabe denunciar a solidão que se opõe à socialização, mas sim construir, a cada encontro transferencial, uma solidão que seja fundamento do laço” (Lyra, 2019c, p. 02). Para falar da condição estrutural da solidão, refere-se à forma como esta aparece nos processos de análise. Em suas palavras: “A solidão, nesse percurso, é o afeto que corresponde 
às mais fundamentais descobertas de uma análise: a de que não existe o Outro que inventamos para nos situar no mundo e a de que os encontros amorosos e sexuais não se dobram aos anseios de um par perfeito" (idem). O autor encerra suas reflexões com uma referência a Miller, na qual o psicanalista francês articula a temática da solidão ao que se vive em uma Escola de psicanalistas. "Mesmo a reunião institucional dos psicanalistas leva a sua marca: uma Escola não pode ser pensada senão como uma "soma de solidões subjetivas"” (Miller, 2016, p.6, opcit Lyra, 2019c, p. 01).

Dunker (2017) contribui para o debate trazendo a correlação da solidão com duas temáticas trabalhadas por Freud e por Lacan. Segundo ele, "a solidão é uma das faces do que os psicanalistas chamam de separação ou de castração. Nela, o objeto com o qual nos identificamos para cobrir nossa falta e nossa falta no Outro é finalmente deslocado de sua função encobridora. Experiência simbólica por excelência, ela traz consigo não a separação para com os outros, mas a distância e o estranhamento com relação a si mesmo. Solidão não é apenas introspecção ou introversão, mas dissolução da própria solidez do ser" (Dunker, 2017, p. 20). Gostaríamos de destacar na abordagem do autor, esse acento que dá à solidão como "experiência de desencontro com si mesmo" (idem), pois pensá-la dessa forma ajuda a perceber que estar acompanhado - seja de um marido ou de um filho, seja em uma conversa com um contato do Facebook - não anula essa dimensão da existência humana. Referimo-nos aqui à dimensão de seres falantes, condenados pela linguagem a sermos radicalmente separados de nós mesmos. Ainda com Dunker (2017) aprendemos que "cultivo da solidão é cultivo do Outro que nos habita" (p. 31) e que a solidão "se associa fortemente aos estados de desproteção e insegurança" (p. 34).

Antes de entrarmos a fundo na noção de desamparo segundo Freud, fundamental para essa discussão, citamos Dessal (2017) e Katz (1996) e suas preciosas contribuições, como uma espécie de preâmbulo ao que virá adiante: "Desde seu momento inaugural, o ser é impelido ao desamparo mais radical, que nem o amor mais perfeito pode remediar: como sujeito da palavra, toda a sua existência é afetada por uma ignorância fundadora, um não saber radical, aquilo que conhecemos como inconsciente ${ }^{2 "}$ (Bauman; Dessal, 2017, p. 111). Em outras

\footnotetext{
${ }^{2}$ Não pretendemos nos dedicar a esse estudo na tese, mas cabe comentar que o conceito de inconsciente em Freud, assim como está colocado por Dessal nessa passagem, também poderia
} 
palavras: "algo na condição humana se repete, visto que não muda nem avança"; "há uma enorme carência, uma ausência incurável"; "essa carência que encontramos no fundo da condição humana persiste e é impossível de preencher"; “A estrutura da subjetividade está afetada por uma carência que nenhum remédio pode curar" (idem, p. 110). A mesma ideia é assim formulada por Katz: "Existe algo no corpo próprio que é do registro de uma solidão absoluta, que nada pode substituir ou representar" (Katz, 1996, p. 183).

\section{3) O desamparo segundo Freud}

Conforme nossas leituras sobre a temática da solidão segundo uma perspectiva psicanalítica foram caminhando, notamos que o tema da solidão remete à noção freudiana de desamparo. Assim sendo, dedicamos a presente seção à exploração desta noção. Sua primeira e paradigmática aparição no pensamento freudiano se dá em 1895, no "Projeto para uma psicologia científica". Segundo Pereira (1999) (em livro dedicado ao tema que tomamos como uma das referências em nosso estudo) o desamparo é uma noção, não é um conceito. Tratase de algo que acompanha o homem durante toda a sua existência, que possui caráter necessário, não sendo temporalmente delimitável, ou seja, algo da ordem do que não pode ser remediado. O desamparo enquanto originário tende a se apresentar como "o horizonte último da existência e do próprio funcionamento psíquico" (Pereira, 1999, p. 144). Assim, para uma compreensão acertada do tema, é fundamental que fique bem claro o fato de que, "para Freud, o desamparo não se esgota na referência ao estado de insuficiência psicomotora do bebê nem se resume a uma condição meramente acidental do funcionamento psíquico" (idem). Estamos diante de um "substrato fundamental de falta de garantias sobre o qual a vida psíquica se desenrola" (Pereira, 1999, p. 125).

Esquematicamente, podemos dividir os esclarecimentos de Pereira sobre o desamparo em Freud em dois tempos: o começo da obra freudiana e o fim de sua vida. Inicialmente, o desamparo é colocado "em termos muito concretos da incapacidade objetiva do recém-nascido em satisfazer por suas próprias forças as

originar um interessante trajeto de reflexão a respeito da solidão, enquanto "desencontro com si mesmo", tal como proposto por Dunker (2017). O golpe narcísico desferido por Freud, ao enunciar que "o eu não é senhor em sua própria morada", também testemunha essa solidão estrutural. 
exigências das suas necessidades vitais" (p. 127). O que está em jogo aqui é "a insuficiência performativa do bebê no plano da auto-conservação" (p. 129). Em textos mais tardios, como "O futuro de uma ilusão" (1927) ou "O mal estar na civilização" (1930) "Freud trata do desamparo a partir da perspectiva da radical falta de garantias do ser humano" (...) "assumindo uma dimensão cultural" (Pereira, 1999, p. 127). É nesse momento que se evidencia o "desamparo fundamental e insuperável", o qual é descrito por Pereira como "dado inelutável" (p. 228): "o homem tem de enfrentar o seu desamparo mais radical, o do lugar vazio do fiador último da história simbólica pessoal e da humanidade”. Freud confere ao desamparo "um estatuto de dimensão fundamental da vida psíquica que indica os limites e as condições de possibilidade do próprio processo de simbolização" (Pereira, 1999, p. 127).

Uma segunda referência que escolhemos para estudar a temática do desamparo em Freud foi Menezes (2012). Em livro integralmente dedicado ao tema - fruto de sua tese de Doutorado - esforça-se por destacar "a posição fundamental do desamparo na constituição psíquica" presente na concepção freudiana. Para ela, o desamparo refere-se a uma problemática e seria prudente considerar seu estatuto como sendo da ordem de uma noção metapsicológica (Menezes, 2012, p. 21). Correlaciona a "realidade do desamparo à condição do limite, da finitude, da solidão, do inominável do resto pulsional” (Menezes, 2012, p. 74), ou seja, "condição de incompletude, do imprevisível" (p. 96). Prosseguindo com a autora: "a condição originária e intransponível do sujeito é a condição de desamparo, de ser desamparado frente a si mesmo e ao mundo, sem poder contar com proteção alguma face aos perigos e a dor" (p. 93). Em sua escrita pretende ressaltar a ideia de que "a subjetividade humana se caracteriza por uma fragilidade estrutural" (p. 96) e nesse contexto o desamparo "designa a condição de ausência de ajuda, em que não há o auxílio de alguém e tampouco se pode contar com proteção alguma (...) evocando o sentido de cair sem ter algo para agarrar-se, escorar-se ou apoiar-se; não há abrigo, não há refúgio, nem alguém que possa socorrer; implica uma condição de abandono, solidão (grifo nosso) e esquecimento. O desamparo é um termo que pressupõe a existência do outro" (Menezes, 2012, p. 24).

Essa passagem "da solidão ao outro", "do desamparo à dependência" é frisada em diversas partes do livro, que traz como uma de suas mais fortes 
mensagens a importância do outro. A autora problematiza o papel do desamparo e do outro na constituição subjetiva, em passagens como essa: como cada um fará o "enfrentamento da condição de ausência de ajuda, de solidão" (...) "o quanto o sujeito pode suportar ou não o fato de que não há proteção absoluta na vida e, tampouco, um ser onipotente que lhe garanta uma estabilidade para sempre" (Menezes, 2012, p. 25). "Essa falta de sustento, de proteção, implica a necessidade de um outro: o indivíduo precisa de alguém ou de alguma coisa que o ajude" (p. 26). Assim, com Freud entendemos que o desamparo é "original, fundante e estruturante do psiquismo" (p. 27). Podemos concluir então que a partir da noção de desamparo desenvolvida na obra freudiana a condição de existência do sujeito no mundo está apoiada numa condição de desamparo do psiquismo.

Após essa introdução via comentadores, vejamos como Freud nos apresentou o tema do desamparo. No "Projeto" de 1895, partindo da descrição do estado de extrema dependência do bebê, introduz a noção de desamparo articulada à condição indefesa do ser humano quando nasce, isto é, à necessidade humana de proteção, dada sua falta de autonomia. "O organismo humano é, a princípio, incapaz de promover [a] ação específica. Ela se efetua por ajuda alheia, quando a atenção de uma pessoa experiente é voltada para um estado infantil por descarga através da via de alteração interna (por exemplo, pelo grito da criança). Essa via de descarga adquire, assim, a importantíssima função secundária da comunicação, e o desamparo inicial dos seres humanos é a fonte primordial de todos os motivos morais" (Freud, 1950 [1895]/1996, p. 370). A impossibilidade de o recém-nascido realizar a ação específica capaz de minorar o desprazer através de uma alteração na realidade externa revela seu estado de desamparo e de dependência do outro. Freud prossegue nomeando o processo: "a totalidade do evento constitui então a experiência de satisfação, que tem as consequências mais radicais no desenvolvimento das funções do indivíduo" (idem).

Em “A Interpretação dos sonhos" (1900) Freud volta a abordar esse momento mítico inaugural: "As excitações produzidas pelas necessidades internas buscam descarga no movimento, que pode ser descrito como uma "modificação interna" ou uma "expressão emocional". O bebê faminto grita ou dá pontapés, inerme. Mas a situação permanece inalterada, pois a excitação proveniente de uma necessidade interna não se deve a uma força que produza um impacto momentâneo, mas a uma força que está continuamente em ação. Só pode haver 
mudança quando, de uma maneira ou de outra (no caso do bebê, através do auxílio externo), chega-se a uma "vivência de satisfação" que põe fim ao estímulo interno" (Freud, 1900/1996, p. 594). Mais uma vez nos deparamos com a descrição de um ser desarmado e indefeso, assim como com a necessidade de um socorro que venha de fora. Há ainda uma menção - indireta, que seja - ao conceito de pulsão enquanto força constante.

Anos depois, em "Inibição, sintoma e angústia" (1926), voltará a frisar que "o fator biológico é o grande período de tempo durante o qual o jovem da espécie humana está em condições de desamparo e dependência. Sua existência intrauterina parece ser curta em comparação com a da maior parte dos animais, sendo lançado ao mundo num estado menos acabado. (...) O fator biológico, então, (...) cria a necessidade de ser amado que acompanhará a criança pelo resto de sua vida" (Freud, 1926/1982, p. 179). A esse respeito, Menezes (2012) comenta que, “em outras palavras, será sempre a perda do outro amado que remeterá à condição de abandono total, de desajuda, de desamparo ante o aumento pulsional" (Menezes, 2012, p. 71).

“O futuro de uma ilusão" (1927) é também um texto-chave para a nossa investigação, pois nele Freud alarga os horizontes da noção de desamparo, referindo-se a algo que permeia a vida humana para além da dependência infantil. Diante, por exemplo, da insubmissão da natureza (com seus terremotos, tempestades e pandemias) a qualquer controle humano e do "penoso enigma da morte", reaparece nossa incompetência para com eles lidar. "Com essas forças a natureza se ergue contra nós, majestosa, cruel, implacável, sempre nos recordando nossa fraqueza e desvalia, que pensávamos haver superado mediante o trabalho da civilização" (Freud, 1927/2014, p. 247). Ao longo do texto, são muitas as referências à ideia de um desamparo constitutivo e insuperável: "para o indivíduo é difícil suportar a existência" (p. 247); "Pois tal situação não é nova, ela tem um modelo infantil; é, na realidade, apenas a continuação daquela anterior, pois o indivíduo já se encontrou assim desamparado: quando pequeno, perante o pai e a mãe...” (p. 249); "Mas permanece o desamparo do ser humano" (p. 249); "persiste a desagradável suspeita de que a perplexidade e o desamparo humanos não podem ser remediados" (p. 250); "necessidade de fazer suportável o desvalimento humano" (p. 251); "O indivíduo em crescimento percebe que está destinado a permanecer uma criança...”; “... necessidade de proteção contra os efeitos da 
impotência humana; a defesa contra o desamparo infantil empresta à reação ao desamparo que o adulto tem de reconhecer seus traços característicos” (p. 258).

Ao trazer com tanta veemência nossa condição de desamparo, Freud procura sustentar sua hipótese de que a busca por ilusões e a formação das religiões seriam formas criadas pelos homens para lidar com isso, para suportar nossa fraqueza (formas altamente criticadas por ele, diga-se de passagem). Dito isso, deixamos a pergunta: seria a navegação nas redes virtuais mais uma dessas formas? O sucesso da internet para a comunicação pode ter um fundo semelhante à adesão em massa às religiões? Desenvolveremos tais questionamentos no próximo capítulo, mas desde já sinalizamos que cada um desses fenômenos possui sua particularidade e que devemos evitar generalizações grosseiras.

Mograbi (2009) demarca que no texto freudiano de 1927 o desamparo aparece ligado à dimensão da falta de garantias e aos limites da simbolização. "O desamparo infantil - nos termos de Freud a necessidade de "proteção através do amor" - não é superado"; "o desamparo do sujeito advém principalmente do confronto com a crueza [da realidade]" (Mograbi, 2009, p. 47). Segundo o autor, "temos com Freud, como concepção reinante, a ideia de um homem que no contato com a realidade se vê desamparado" (p. 48).

Outra característica marcante, a qual nos interessa sublinhar, é a do amor face ao desamparo. A necessidade de proteção através do amor novamente abordada aqui por Freud é entendida como algo que perdura por toda a vida. Como pontua Menezes (2012), “o desamparo infantil implica para o bebê, uma abertura ao mundo adulto, ao mundo do outro" (p. 38). Tal vivência deixará marcas, o que decorre na afirmação de que "o desamparo expressa a dimensão fundamental e insuperável sobre a qual repousa a vida humana” (p. 88). É fundamental atentarmos desde já para um aspecto complexo das considerações freudianas em relação ao amor. Ao mesmo tempo em que aborda, mais de uma vez, a necessidade de buscar proteção através do amor, falará, também reiteradas vezes, do quanto o outro nos assola, desaponta, faz sofrer. A passagem a seguir, extraída de "A Etiologia da histeria" (1896) ilustra esse último aspecto que salientamos: "a criança, que em seu desamparo, está à mercê da vontade arbitrária do [adulto], que prematuramente é despertada para todo tipo de sensibilidade e exposta a toda sorte de desapontamento" (Freud, 1896/1982, p. 242 apud 
Menezes, 2012, p. 41). Novamente vemos aqui a ideia de que "o desamparo coloca o ser humano a mercê do outro", nos diz Menezes (p. 41).

Em sua abordagem acerca do desamparo, Menezes (2012) procura mostrar que a aparição de um desamparo mais radical, não restrito ao aspecto biológico, ocorre em Freud desde o princípio de suas teorizações. "Mesmo no início do pensamento freudiano já há uma significação a posteriori do desamparo motor no desamparo psíquico" (p. 39), sugere a autora. Defende, portanto, que "essa dimensão do desamparo enquanto uma situação objetiva do bebê é apenas uma das perspectivas teóricas da questão no discurso freudiano; não é a única, nem tampouco, sua principal tendência de elaboração. Ao longo de sua obra - e mais evidentemente nos textos freudianos de 1926, 1927 e 1930 - o desamparo se apresenta cada vez menos como originário e cada vez mais como horizonte da própria existência humana e do funcionamento do psiquismo" (idem). A construção do psiquismo se dá, portanto, a partir de um fundo de desamparo e este, em última instância, diz respeito à nossa falta de garantias sobre o existir e sobre o futuro.

Em continuidade com o texto de 1927, “O mal-estar na civilização” (1930) apresenta a ideia de um mal estar ineliminável, “... um mal estar que nenhum cuidado materno pode compensar" (Espinel, 2011, p. 106). Esse aspecto pode ser observado na passagem a seguir: "o homem (...) surgiu primeiramente como um fraco animal e cada indivíduo de sua espécie tem que novamente entrar como uma desamparada criança de peito" (Freud, 1930/2010, p. 51).

Além dessa referência explícita ao desamparo originário, interessa-nos para essa discussão a reflexão feita por Freud a respeito da miséria humana na sociedade, decorrente do "conflito irreconciliável" (Freud, 1930/1997, p. 50) entre as reivindicações pulsionais dos indivíduos e os anseios civilizatórios. Recortamos esse aspecto do conflito para acompanhar Menezes (2012) e Dessal (2017) na interessante interpretação que fazem, cada um a seu modo, propondo uma articulação das noções de desamparo e de conflito. A dimensão do conflito vê-se aqui ampliada para além daquele que vivenciamos na convivência com o outro e a partir das negociações e restrições impostas pela demanda civilizatória. Há um terceiro modo de conflito, que diz respeito à lida do sujeito consigo mesmo: “Como a condição de desamparo estrutural é inaceitável para o sujeito, ele estabelece a relação de conflito interminável com a condição de desamparo" 
(Menezes, 2012, p. 90). Estando às voltas, desde sempre e para sempre, com essa condição, digamos, pouco palatável e desafiadora, o sujeito humano vive em constante conflito com sua solidão estrutural. Este ponto nos interessa especialmente em nossa pesquisa, já que nos vemos instigados a problematizar as novas nuances trazidas pelo advento da internet para a lida de cada um consigo mesmo. Inquieta-nos pensar as incidências da navegação na web sobre esse sujeito em constante conflito, não só com o outro, mas também (e, sobretudo) consigo.

Nesse sentido, Dessal (2017) situa em "O mal estar" (Freud, 1930) a aparição, de forma implícita, da ideia de que há uma quarta fonte de sofrimento para os homens, que se soma às três descritas no texto: a natureza, o corpo, os outros homens. "O homem encontra em si mesmo a mais intensa e incontrolável fonte de sofrimento"; "Antes de tudo, o homem é seu próprio lobo"; "Ninguém pode se considerar a salvo de si mesmo: estamos sempre ameaçados diante da possibilidade de nossa própria traição" (Bauman; Dessal, 2017, p. 22); "O inferno se esconde em nosso interior" (idem, p. 24). Segundo a leitura desse psicanalista, a tese central de "O mal estar" é: "acima (ou abaixo) de todos os medos que nos ameaçam, o mais temível é aquele que nos espreita de dentro de nós mesmos, e que se origina nessa força demoníaca que Freud denominou a 'pulsão de morte ${ }^{3}$ ", (ibidem, p. 23).

Com Menezes, novamente, observamos que essa correlação entre o conflito irremediável e o desamparo é uma das formas de Freud abordar a finitude do sujeito. Nesse contexto, aponta-se ainda o uso particular que fez da expressão mal estar, visando referir-se ao destino trágico do sujeito para a psicanálise. Desde "O mal estar..." Freud (1930) deixa claro que, "para viver, as pessoas criam possibilidades afetivas no enfrentamento da condição fundamental de desamparo". (...) “Sob esse prisma, não há cura possível para o desamparo humano, pois frente a ele, o sujeito precisa, constantemente, reinventar novos destinos para seu desamparo e tornar sua existência possível" (Menezes, 2012, p. 91). A autora recorre a Birman ao apresentar tal ideia, citando as seguintes passagens: "o desamparo do sujeito é a matéria prima da psicanálise"; “ser sujeito,

\footnotetext{
${ }^{3}$ Consideramos o conceito de pulsão de morte como mais um dos conceitos de Freud que serviriam a uma reflexão a respeito da solidão estrutural. Todavia, optamos por não nos aprofundarmos neste conceito em nosso recorte, temendo nos estendermos demasiadamente em uma explanação teórica, podendo prejudicar a fluidez da tese, assim como tirar o foco da reflexão acerca da internet.
} 
pois, é ter de recomeçar insistentemente seu percurso singular" (Birman, 2001, p. 95 apud Menezes, 2012, p. 94). Acompanhando esses autores, podemos pensar que o advento da internet propiciou a criação de possibilidades inéditas nesse sentido? Em outras palavras, a navegação na web pode ser interpretada como um modo de inventar "possibilidades afetivas no enfrentamento da condição fundamental de desamparo"?

Esse exercício que fazemos de relançar essa questão fundamental da psicanálise referindo-a a um momento específico da história e a um fenômeno pontual da experiência humana faz sentido na medida em que o mal estar, “expressão da condição subjetiva do humano, marcada pelo desamparo estruturante do psiquismo, tenderá sempre a existir, porém configurado segundo as modalidades de subjetivação de sua época. As formas de sofrer que os sujeitos manifestam, seus mal estares, são indissociáveis das transformações que remodelam o campo social" (Menezes, 2012, p. 105). Desejamos, portanto, pensar o recurso à internet como um dos "arranjos e negociações subjetivas que o sujeito tece frente a seu desamparo" (Menezes, 2012, p. 107). A proposta é, pois, partir das considerações psicanalíticas a respeito da solidão humana para pensar sobre a adesão maciça dos sujeitos contemporâneos às tecnologias da comunicação. Para tal, entender que nossa existência é marcada por uma fragilidade, por uma vulnerabilidade, por uma insuficiência, que somos seres atravessados por uma precariedade e pela finitude da experiência da vida nos parece um caminho profícuo.

\section{4) A linguagem em Lacan}

Nessa etapa de nosso estudo, desejamos abordar os aspectos da existência humana acima trabalhados através de algumas conceituações de Lacan relativas ao tema. Focaremos naquilo que Lacan avançou, a partir de Freud, ao aprofundarse na dimensão da linguagem em sua abordagem do humano. Interessa-nos, especialmente, o pressuposto lacaniano de que a linguagem tem incidência de corte no sujeito, ou seja, que em sua relação com a linguagem o sujeito depara-se com o impossível. A proposta é, assim, somar às noções freudianas de "desamparo", "mal estar ineliminável” e "conflito irreconciliável”, as teorizações lacanianas que servem a uma reflexão a respeito da solidão estrutural, como, por 
exemplo, sua concepção do homem como alguém que, por não ser comandado por um saber instintivo, por nascer destinado à linguagem, por precisar recorrer às palavras para veicular o que deseja, vive o mal-entendido do significante. Desde já, destacamos a importância das dimensões da "impossibilidade" e do "malentendido", às quais recorreremos em nossa discussão acerca da conectividade da Era Digital a partir de Lacan.

É importante marcar que optamos por recorrer diretamente à obra de Lacan apenas pontualmente, apostando que, ao apresentarmos os apontamentos de autores que se debruçaram mais detidamente em seu ensino, traríamos material suficiente para os fins que buscamos em nossa pesquisa. Dito isto, apresentamos a seguir valiosas colocações de Dessal (2017) sobre o homem, que incluem contribuições lacanianas à visada freudiana acerca do homem e seu desamparo constituinte: "A criatura humana que sofre essa grave e incurável enfermidade denominada linguagem"; Humanos enquanto "seres que padecem da linguagem", “estranho vivente que, por mediação da linguagem, é construído de um modo falho, inacabado, e cuja incompletude o impele à busca dos maiores êxitos, mas também, em muitas ocasiões, à incontrolável necessidade de ressarcir-se como quer que seja do sentimento de haver sido despojado de algo que não encontra satisfação" (Bauman; Dessal, 2017, p. 111). E ainda: "o profundo vazio no qual estamos afundados na condição de seres falantes” (idem, p. 125).

De Quinet (2012), nos servimos das explanações precisas que traz visando definir o grande Outro. O grande Outro, simbólico, constituído pela linguagem, é aquele cujo discurso constitui o inconsciente. É o Outro da linguagem, de onde vêm as determinações simbólicas da história do sujeito. Representado como A ("a" maiúsculo, primeira letra de "autre" /outro em francês) é o lugar onde se coloca para o sujeito a questão de sua existência, de seu sexo e de sua história. "É um lugar simbólico, lugar dos significantes, onde as cadeias significantes do sujeito se articulam determinando o que o sujeito pensa, fala, sente e age" (Quinet, 2012, p. 22).

Após essa introdução, aparecem aspectos do Outro da linguagem que aludem diretamente à condição desamparada do sujeito, foco de nosso interesse. "O sujeito se encontra alienado a esses significantes que são do Outro" (p. 23); "O Outro falta" (p. 30); "sendo o Outro barrado, não há garantia nenhuma de nada" (p. 31). A cada frase, reforça-se a mesma ideia, do sujeito face-a-face com a falta. 
“O sujeito como ser-de-linguagem, o qual é também ser-para-a-falta, pois se ele está na linguagem esta não o apreende: o sujeito é falta-a-ser porque falta um significante que o defina" (idem). "E, na psicanálise, quando lemos o matema $\mathrm{S}(/ \mathrm{A})$ como sem álibi significa que todo tipo de álibi está riscado. O sujeito em sua vida procura um Outro em que possa se ancorar: seu amor e sua segurança. Mas o Outro falta por estrutura, e o sujeito ao longo da vida só encontra alguns substitutos, e mesmo assim jamais a completude, pois o Outro é incompleto e inconsistente. Ao se deparar com a falta do Outro, é o desamparo que pode advir, conforme salientou Freud" (idem). Extraindo de Quinet os termos “álibi” e "substitutos", no capítulo subsequente procuraremos explorar a hipótese de que, para alguns, conectar-se à internet pode vir a funcionar como um álibi, como um dos substitutos construídos frente à falta do Outro.

Pereira (1999) trabalha a falta-a-ser como "falta fundamental, irremediável e intratável; ela é uma contingência da linguagem: uma vez que esta não tem a capacidade de dizer a última palavra sobre a verdade do ser" (Pereira, 1999, p. 229). Segundo o autor, Lacan percebeu o imenso alcance teórico da noção freudiana de desamparo e se esforçou em demonstrar seu interesse metapsicológico. Pereira afirma que chegará a considerar "o desamparo como sendo o fundamento último da vida psíquica, à medida que esta é, segundo sua teoria, essencialmente um fato de linguagem” (p. 227). Em uma referência um pouco mais direta à condição do bebê ao nascer (mas não só), nos fala de uma "falta irremediável de "ajuda"" (idem). Sobre isso, Pereira nos remete ao "seminário, livro 07" de Lacan, a partir do qual comenta: "o desamparo não acidental, mas fundador da condição mais fundamental do sujeito, ante a qual "não tem de esperar ajuda de ninguém"”' (p. 235). Para Lacan, a situação inicial de desamparo e dependência "deixa transparecer uma falta fundamental - cujo sentido subjetivo é o de uma perda ou de uma separação - à qual cuidado algum pode suprir" (Pereira, 1999, p. 228).

Transpondo tais considerações ao tema da tese, podemos afirmar tratar-se aqui da solidão do sujeito em relação ao Outro, solidão do inconsciente dos seres falantes e sexuados, conforme sugere a passagem a seguir: "Trata-se de conceberse apartado do Outro, solitário" (Coelho, 2010, p. 42). A solidão é, nesse sentido, relativa à linguagem, já que "há uma espécie de solidão inerente que não se comunica” (Martins; Maciel, 2007, p. 192). Faltam palavras para expressar o que 
queremos dizer, para fazer com que o outro nos entenda e isso nos joga de volta à solidão. "Há sempre uma parte que a palavra não alcança" (Carneiro, 2007, p. 31). Ou ainda, "nenhuma palavra pode dizer toda a verdade" (Bauman; Dessal, 2017, p. 08).

A partir da ênfase apresentada por Lacan na defasagem e disparidade constatadas entre o sujeito e o Outro, precisamos forjar modos de nos relacionar com este último. Por sermos seres constituídos na e pela linguagem, experimentamos a toda hora o brusco intervalo entre quem fala e quem escuta, ou seja, estamos cotidianamente às voltas com o mal entendido da linguagem. Como nos ensina Costa-Moura (2006) em referência ao Outro tomado como alteridade radical, "as palavras são sempre do Outro!"; "Não encontramos nunca, na justa medida, a nossa palavra" (Costa-Moura, 2006, p. 149). De modo semelhante, acrescenta Pereira (1999): “o grande Outro interpelado como lugar do código, da linguagem, como fiador final de tudo o que é da ordem da ancoragem simbólica da existência, não está ele próprio de posse de todas as significações que o sujeito poderia considerar, aliviado, como finais e definitivas. Há uma falta essencial do significante no Grande Outro" (Pereira, 1999, p. 236); “falta da significação definitiva da qual nos fala Lacan" (p. 237). Merece destaque nova menção ao desamparo que faz este autor, agora o relacionando diretamente à linguagem, ou seja, apresentando uma perspectiva essencialmente freudo-lacaniana com a qual nos afinamos: "A organização simbólica do mundo repousa, portanto, sobre uma base de desamparo"; "Este desamparo é, portanto, correlativo da própria linguagem" (p. 236).

Outra formulação de Lacan interessante para pensarmos sobre a solidão é aquela em que apresenta o sujeito enquanto \$, sujeito barrado pela linguagem, alienado dentro do Outro, alienado na/pela linguagem, castrado. O sujeito aqui é falta a ser, uma vez que é eclipsado pelo Outro, isto é, pela ordem simbólica (Fink, 1998, p. 11). Em outros termos, trata-se de um sujeito dividido, que padece do $-P h i$, do desencaixe, tendo apenas a bateria significante para dizer algo sobre ele, algo parcial, jamais tudo. Dito de outro modo, "o campo da linguagem não faz senão tornar o sujeito um servo, servo de sua própria divisão" (Flanzer, 2004, p. 160). Ou ainda: "o sujeito dividido é um sujeito às voltas com a falta-a-ser, apaixonado pelo significante que sustenta sua existência ao mesmo tempo em que o barra, nadificando-o, alienando-o" (Leguil, 2014, p. 444). Nesse ponto, nos 
serve bem a construção teórica de Ferrari (2008), quando enuncia "uma solidão própria ao sujeito barrado" (Ferrari, 2008, p. 26).

Bassols (1994) encara a solidão como um afeto vinculado ao da angústia, já que a primeira experiência de solidão é também uma primeira experiência de angústia, por uma falta que, em primeiro lugar, se detecta como uma falta do Outro. Segundo ele, a solidão é o afeto inerente ao ser que fala, só podendo haver experiência da solidão em relação ao Outro da palavra e da linguagem, ao Outro simbólico da presença e da ausência. Há uma primeira solidão que é generalizável para todo sujeito da palavra. É a solidão do ser no mundo que podemos definir como a solidão da falta-a-ser, que escrevemos como \$. A solidão estrutural não se opõe ao laço com o Outro, mas ao contrário, o supõe. É uma solidão que supõe um laço com a pergunta pelo desejo do Outro, um Outro que poderia solucionar a falta- a- ser inerente ao sujeito. Toda vez que o Outro não oferece ao sujeito seu complemento de ser, ele responde com o sentimento de solidão, pois esse sujeito espera encontrar sua completude no Outro para esconder ou recobrir sua própria falta-a-ser, nos ensina Bassols. Inclui ainda em sua análise aquilo que nomeia como uma "outra solidão mais decisiva: a solidão frente ao silêncio da pulsão", "a solidão inerente ao gozo", e afirma: "na satisfação da pulsão o sujeito sempre está sozinho"; "a solidão mais absoluta da pulsão de morte (...) que deixa esse homem sozinho frente ao seu ser mortal" (Bassols, 1994, p. 27).

A questão do desejo do Outro relacionada à solidão e ao desamparo mencionada por Bassols também interessa a Pereira (1999) e a Menezes (2012). Para o primeiro, "o desamparo que o sujeito tem estruturalmente de enfrentar é, sobretudo, o da opacidade do desejo do Outro, diante do qual o sujeito se vê sem recursos" (p. 232). A condição de desamparo "não é contingente, não depende de um acidente qualquer. Ela é constituinte da inserção do sujeito na linguagem e na sua relação ao desejo do Outro" (Pereira, 1999, p. 233). Menezes, por sua vez, nos traz um trecho do "seminário, livro 07 " de Lacan para dar corpo ao seu pensamento: "Lacan (1958-1959) mostra que o desamparo de Freud é a posição de estar sem recurso diante do desejo do Outro: "O sem recurso diante de quê? O que não pode ser definível, centrável de nenhum outro modo senão diante do desejo do Outro. É essa relação do desejo do sujeito, na medida em que ele deve se situar diante do desejo do Outro que, entretanto, literalmente o aspira e o deixa sem recursos, é nesse drama da relação do desejo do sujeito com o desejo do 
Outro que se constitui uma estrutura essencial"' (Lacan, 1958-1959/1988, p. 452 apud Menezes, 2012, p. 32). Conforme a leitura dessa autora "é Lacan - no seu retorno à obra de Freud - quem demonstra a relevância do desamparo no discurso freudiano e a ideia de que este foi se impondo à Freud como uma problemática" (idem).

Por fim, cabe mencionar brevemente uma articulação possível entre o registro do real e a dimensão do desamparo, trazida com clareza na formulação a seguir: "Então, é do real que se trata, quando está em jogo a precariedade do sujeito, o desamparo sempre possível que o ameaça" (Espinel, 2011, p. 107). O real como o que escapa irredutivelmente às possibilidades de uma apreensão simbólica, o real como impossível, um real que ex-siste ao mundo, não permitindo nem unidade, nem sentido. Tal como o define Lacan, "o real é o que não funciona” (Lacan, 1974/2003, p. 63). "O real inventado por Lacan não é o real da ciência. É um real ao acaso, contingente, na medida em que falta a lei natural da relação entre os sexos. É um furo no saber incluído no real” (Miller, 2016). A respeito desse ponto, interessa-nos um aprofundamento na ideia de uma solidão real que afeta as condições íntimas de cada indivíduo, pensando se isso é passível de ser amenizado pelas trocas virtuais e no quanto disso é compartilhável. A conexão em rede pode ser concebida como mais uma invenção de cada um frente ao real que nos habita? Ainda que se lance mão dessa novidade como forma de atenuar o sofrimento proveniente da incidência do real em nós, é preciso sublinhar, de saída, que o mundo virtual não está isento dos efeitos desse real postulado por Lacan. A internet não se constitui como um campo de exceção nesse sentido, ou seja, o ciberuniverso não nos blinda dos impactos do real aos quais estávamos habituados a viver no passado.

Encerramos essa seção com Ferrari (2008), destacando de suas contribuições o significante "perda", caro para nós nessa pesquisa. "Para Lacan, o fato de o sujeito constituir-se na linguagem sempre supõe perda. Ao longo de seu ensino, chamou-a de perda de gozo natural da vida, perda do ser" (Ferrari, 2008, p. 24). "Só pode haver experiência de solidão em relação ao Outro da palavra e da linguagem, Outro da presença e da ausência” (p. 26). Ferrari apontará ainda para a continuidade por nós mencionada entre as temáticas da solidão e do laço com o outro, ideia que explicita de forma clara e concisa no trecho que citamos a seguir: "a solidão estrutural não impede laços sociais, porque presume um laço com a 
pergunta pelo desejo do Outro, hipoteticamente capaz de solucionar a falta a ser inerente ao sujeito" (Ferrari, 2008, p. 26).

\section{5) Do desamparo à dependência: complexidades entre o sujeito e o outro}

Solidão é uma ilha com saudade de barco Adriana Falcão, Mania de Explicação

É com essa imagem que escolhemos iniciar essa seção, na qual exploraremos as complexidades existentes entre o sujeito e o outro, entre a solidão e o laço, segundo a abordagem psicanalítica. A frase citada compõe o livro "Mania de Explicação", espécie de dicionário lúdico para crianças (e adultos) onde encontramos tentativas poéticas de definir temáticas complexas da vida, sendo uma delas a solidão. A alusão a "uma ilha com saudade de barco", algo tão simples e concreto, nos caiu como uma luva para introduzir a temática que desejamos, bem menos simples e bem mais abstrata. Falcão (2013) nos presenteia com a ideia de que a solidão já traz, de forma implícita, a referência a outra coisa. É um sentimento que só pode ser experimentado porque já não se foi só, ou seja, o "sentir-se só" possui internamente uma referência ao já ter estado acompanhado. A autora parece incluir, assim, a presença/ausência do outro em seu modo de tratar o tema, de passear poeticamente pela questão.

Do ponto de vista da psicanálise, como começamos a ver anteriormente, há uma ligação primordial com o outro, que se apresenta junto à dimensão do desamparo originário, através, por exemplo, da experiência de satisfação. O eu não é sem o outro, o outro é fundante segundo a leitura psicanalítica do homem. Ao trabalhar a correlação entre o desamparo inicial e o fato do outro ser peça fundamental na constituição do eu, nos coloca Pereira (1999): "Há uma abertura, desde o início, do bebê para o mundo adulto" (Pereira, 1999, p. 137). Sendo assim, o laço com o outro nessa interface com o desamparo é fundamental, fundante e necessário. Audibert (2008) sublinha tal fato, nomeando-o como um paradoxo, um "paradoxo inicial, mas essencial: "a solidão do humano não pode existir senão porque ele não esteve só" (Audibert, 2008, p. 14). Desenvolvendo esse ponto de vista dirá que "um bebê sozinho não existe. A solidão de um bebê o faria inexistir" (idem). Com Lacan aprendemos o mesmo, em uma de suas belas 
formulações a respeito do jogo do fort-dá explorado por Freud: “ (...) é já na sua solidão que o desejo do homenzinho se tornou o desejo de um outro, de um alter ego, que o domina e cujo objeto do desejo é, daí por diante, a sua própria pena (Lacan, 1953-1954/2009, p. 228).

Pesquisando a respeito do tema, tivemos a felicidade de encontrar a dissertação de Santos (2012), intitulada "A função da alteridade em face do desamparo no processo de constituição subjetiva" ${ }^{4}$, da qual destacamos o binômio desamparo-alteridade sublinhado pela autora, que nos serve com precisão em nosso próprio percurso teórico. A ideia central, bem resumida por Santos, é a seguinte: “A espécie humana é marcada por uma precariedade biológica que impõe uma abertura à dimensão da alteridade como meio de sobrevivência e subjetivação. O recém-nascido, por causa de sua imaturidade motora e psíquica, é incapaz de satisfazer por si só as suas necessidades vitais de sobrevivência. Em contrapartida, surge o desamparo psíquico e a dependência do outro, os quais se instauram no psiquismo como condição estruturante do próprio sujeito" (Santos, 2012, p. 07). Partindo do pressuposto de que "esse estado característico do início da vida, lança o homem ao campo do Outro, da linguagem e da cultura" (idem), traz a associação - com a qual nos afinamos - entre o estado de desamparo e a incerteza proveniente da ausência de garantias provindas do outro. Destacamos por último o já mencionado binômio desamparo-alteridade e o acento que é dado “à alteridade como um complexo de dupla face: tecido em uma relação que remete o sujeito ao mesmo tempo ao semelhante e ao estranho, o que engendra um risco para o mesmo: não há qualquer garantia quanto ao que se pode esperar do outro" (ibidem).

Interessa-nos ressaltar então que o outro comparece em nossas vidas muito cedo e nela permanecerá, em alguma medida, até o final. Suas incidências sobre o sujeito em formação são profundas, o outro exerce um papel constitutivo. Acentuamos ainda o aspecto de dupla face do outro trazido por Santos (2012), semelhante e estranho, o qual exploraremos adiante. Esse risco experimentado frente à presença ambivalente do outro, ora traumático ora apaziguador, ou

\footnotetext{
${ }^{4}$ Em parceria com FORTES, I. Santos escreveu o artigo "Desamparo e alteridade: o sujeito e a dupla face do outro" (2011) também interessante para a abordagem desta temática. Disponível em: http://www.scielo.br/scielo
} 
melhor, traumático e apaziguador, é um dado conceitual valiosíssimo para as reflexões em que nos lançaremos a respeito das navegações na web.

Com Freud aprendemos que a forma como o bebê humano chega ao mundo, sempre prematuro e vulnerável, dá provas de que a dependência é um fato da vida. Na experiência de satisfação primária o papel do outro é sublinhado, pois, se o bebê fosse deixado à própria sorte acabaria morrendo. Essa incapacidade do ser humano de sobreviver sem um cuidado externo exige que nos relacionemos com o outro desde o instante inaugural de uma vida. A dependência do outro para interpretar o apelo contido no choro do bebê, para alimentar-lhe e aquecer-lhe é um dado definidor do humano, que deixa marcas. Segundo Freud, os primeiros objetos de amor são aqueles que cuidam. Tal afirmação pode ser encontrada, por exemplo, no texto "Introdução ao Narcisismo" de 1914: "Na escolha de objeto pela criança (e o adolescente) vimos primeiro que ela toma seus objetos sexuais de suas vivências de satisfação" (Freud, 1914/2010, p. 31). Partindo da noção de apoio (entre a sexualidade e as necessidades fisiológicas), afirma que "as pessoas encarregadas da nutrição, cuidado e proteção da criança tornam-se os primeiros objetos sexuais, ou seja, a mãe ou quem a substitui” (p. 32).

Em "Os três ensaios sobre a teoria da sexualidade" (1905/1996) afirmara de modo semelhante que "a criança aprende a amar outras pessoas que a ajudam em seu desamparo e satisfazem suas necessidades, e o faz segundo o modelo de sua relação de lactente com a ama e dando continuidade a ele" (Freud, 1905/1996, p. 210). Anos mais tarde, em “O futuro de uma ilusão" (1927) Freud trará novamente essa ideia, ao discorrer sobre "o tipo de escolha de objeto por apoio": "a libido acompanha as vias das necessidades narcísicas e se apega aos objetos que garantem sua satisfação. Assim, a mãe que satisfaz a fome da criança torna-se o primeiro objeto de amor" (Freud, 1927/2014, p. 257).

As considerações de Freud sobre a angústia infantil também exprimem a importância do outro e do amor para o sujeito. Novamente em "Os três ensaios" (1905) presta um esclarecimento sobre a origem dessa angústia relatando uma história vivenciada por um menino de três anos, que rogava à tia, de um quarto escuro, que falasse com ele. "Estou com medo porque está muito escuro", dizia. E a tia lhe respondeu: "De que lhe adianta isso? Você não pode mesmo me ver". "Não faz mal", respondeu o menino, "quando alguém fala fica mais claro". A partir do ocorrido, Freud pôde concluir que "o que ele temia não era a escuridão, 
mas a ausência de uma pessoa amada, e pôde prometer que se acalmaria tão logo desse uma prova da presença dela". (Freud, 1905/1996, p. 212). Pereira (1999) desdobra as colocações freudianas a respeito dessa importância do amor, na passagem que transcrevemos a seguir: "Como Freud sustentará trinta anos mais tarde, em "Inibição, sintoma e angústia" (1926), sentir-se amado pelo ser superior representa, no inconsciente, a proteção contra todas as ameaças. Correlativamente, a perda do amor ou a separação do ser protetor corresponde ao maior dos perigos: o de ser abandonado à sua própria sorte ante um desamparo sem esperança" (Pereira, 1999, p. 137). Referindo-se agora a Lacan, corrobora a mesma ideia: "Para Lacan, a dependência da criança em relação à mãe é, sobretudo, uma dependência de amor e não vital" (p. 232).

Pereira (1999) articula a temática do amor acima descrita com a questão da dependência que o nascimento de um humano inaugura. "Segundo Freud, a incapacidade da criança de realizar por si própria a ação específica obriga-a a uma abertura dependente ao mundo adulto. Tal estado de coisas implica que é decisivo para a criança sentir-se amada por seus pais, ou seja, que ela corresponda a seus desejos, o que transforma a impotência original do ser humano na "fonte primordial de todos os motivos morais"” (Pereira, 1999, p. 129). O autor prossegue em sua leitura de Freud a respeito da incapacidade do ser humano de realizar a ação específica por seus próprios meios, para então frisar: "Ele precisa de ajuda exterior de um adulto benevolente que efetue essa tarefa em seu lugar"; "A hipótese freudiana propunha, pois, que o processo desiderativo instaura-se a partir de uma experiência inaugural de satisfação propiciada pela intervenção benfazeja do outro. O caráter necessário dessa abertura ao outro funda-se, em última instância, no desamparo inicial do ser humano" (Pereira, 1999, p. 136). É o que aponta Carneiro (2007), aludindo diretamente à ponte entre solidão e laço, ou seja, à importância do outro como um certo modulador da solidão: “Ao longo da vida, precisamos de afeto, de reconhecimento e de troca. Nos sentimos sós e buscamos o outro" (Carneiro, 2007, p. 26).

Como vimos anteriormente através das passagens trazidas de "Projeto para uma psicologia científica" (1895) a experiência de satisfação referida por Freud atesta a importância do outro para a sobrevivência física do indivíduo, mas sem dúvida já aponta para um papel a mais do adulto, relacionado à subjetivação do recém-nascido. Menezes (2012) é esclarecedora em sua abordagem acerca de 
nossa ligação primordial com o outro e suas consequências para o psiquismo. Traçando uma ponte entre o manuscrito pré-psicanalítico e "Os três ensaios", dirá: “A partir de 1905, Freud correlaciona o desamparo à total dependência da criança em relação à mãe, introduzindo na problemática do desamparo a influência decisiva na fundação e estruturação do psiquismo, voltado a constituir-se inteiramente na relação com o outro. Portanto, dizer que o sujeito freudiano se constitui na relação com o outro é dizer que o sujeito é construído a partir de algo que lhe transcende, que lhe é exterior" (Menezes, 2012, p. 44). "O sujeito humano não se constitui apenas por seus meios, mas ele precisa da ajuda de um outro", complementa a autora (p. 49).

O papel fundamental do outro na constituição do Eu é bastante explorado por Freud no momento em que conceitua o Narcisismo. Em 1914, ao trabalhar a passagem do autoerotismo ao narcisismo, afirma: "uma unidade comparável ao Eu não existe desde o começo no indivíduo; o Eu tem que ser desenvolvido. (...) deve haver algo que se acrescenta ao autoerotismo, uma nova ação psíquica, para que se forme o narcisismo" (Freud, 1914/2010, p. 19). Na leitura que faz dessa colocação de Freud - intensamente desenvolvida por diversos comentadores do autor - Lacan interpreta essa "nova ação psíquica" como correlata ao que propôs como sendo o "estádio do espelho". Passemos então para as proposições lacanianas contidas no escrito assim nomeado.

Em "O estádio do espelho como formador da função do eu" (1949/1998) Lacan reflete sobre "o efeito no homem (...) de uma insuficiência orgânica de sua realidade natural" (Lacan, 1949/1998, p. 99). Partindo da "verdadeira prematuração específica do nascimento no homem" (p. 100), realça o quanto a presença do outro é constitutiva do eu, na medida em que o reconhecimento da própria imagem só se dá com a inclusão desse outro na cena. É preciso "compreender o estádio do espelho como uma identificação" (p. 97), nos diz Lacan. O "filhote do homem", ainda "mergulhado na impotência motora e na dependência da amamentação" depende da identificação com o outro para adquirir sua função de sujeito. Precipitando-se de uma imagem despedaçada de corpo até uma forma de sua totalidade, assume-se uma identidade alienante. Nas palavras do autor: "Esse momento em que se conclui o estádio do espelho inaugura, pela identificação com a imago do semelhante (...) a dialética que desde então liga o 
$[e u]$ a situações socialmente elaboradas. É esse momento que decisivamente faz todo o saber humano bascular para a mediatização pelo desejo do outro" (p. 101).

Em continuidade com a perspectiva freudiana sobre o humano, vemos que Lacan nos traz novas contribuições para pensarmos sobre a solidão. De forma semelhante àquela utilizada por Freud em suas análises sobre o início da vida, no "Estádio do espelho" (1949/1998) destaca a "impotência motora", a "dependência da amamentação" (p. 97) e a "insuficiência orgânica de sua realidade natural" (p. 99) como marcas diferenciais dos bebês humanos. Complementa suas considerações apresentando-nos aquilo que denominou de "o estádio do espelho": "um drama cujo impulso interno precipita-se da insuficiência para a antecipação" (Lacan, 1949/1998, p.100). Trata-se, portanto, de um texto fundamental em nosso percurso de pesquisa, que enriquece a abordagem do desamparo originário e, por conseguinte, a reflexão acerca da solidão e do papel estruturante do Outro no processo de subjetivação.

Quinet (2012) trabalha a questão da alteridade na obra de Lacan, de onde extrai a afirmação “não há sujeito sem outro" (Quinet, 2012, p. 07). Dessa leitura, destacamos a distinção esclarecedora desenvolvida pelo autor com relação aos termos "outro" e "Outro", tais como Lacan os utiliza em seu ensino. O outro grafado com “o” minúsculo, é assim definido: "O pequeno outro, o semelhante, igual e rival, que se encontra no par do estádio do espelho, sendo, portanto, do registro do imaginário" (idem). O outro iniciado com "O" maiúsculo é nomeado por Lacan como "o grande Outro, cujo discurso é o inconsciente, que se manifesta nos sonhos, lapsos, sintomas e chistes e que, por ser da ordem do simbólico, é tecido de linguagem e pode ser "encarnado" no Outro do amor - inclusive o amor de transferência - , ao qual se dirigem as demandas e ao qual está articulado o desejo" (ibidem).

Isso posto, prossegue sua elucidação dos ensinamentos de Lacan, trazendo agora a célebre afirmação "O eu é - antes de mais nada - outro", enunciada por Lacan em “O seminário, livro 2" (Lacan, 1954-1955/1985, p. 16). Traduzindo a seu modo, sugere Quinet: "Aquele que vejo na minha frente, como outro - foi a partir dele que eu fui feito" (Quinet, 2012, p. 08). A essa afirmação, encadeia tantas outras, interessantes para consolidar essa mesma ideia: "Mas que confusão!!!! É isso mesmo: o eu e o outro se confundem”; “O eu é constituído pela imagem do outro" (p. 09). "A indissociabilidade entre o eu e o outro traz a 
marca, e é datada, do estádio do espelho" (p. 10); "A constituição do eu através da imagem do outro" (p. 10). Em referência explícita ao texto de Lacan, Quinet (2012) afirma que “o estádio do espelho corresponde à antecipação, através da imagem, da unificação do corpo, antecipação relativa à imaturidade neurológica da criança"; "Lacan o eleva à dignidade de uma matriz simbólica da constituição do eu" (Quinet, 2012, p. 12).

Pereira (1999), em referência ao estádio do espelho, destaca que, ao ser humano não é permitida a experiência imediata de um corpo unificado. Sobre isso, "Lacan faz intervir a função primordial da imagem do outro como elemento indispensável para dar antecipadamente à criança a experiência da unidade de seu próprio corpo"; "o eu edifica-se a partir de uma alienação fundamental na imagem do outro, narcisicamente investida, e que dará, antecipadamente, uma primeira matriz da imagem unificada do eu" (Pereira, 1999, p. 229). O autor ressalta ainda a importância do olhar do outro na cena, assim como a dependência de "uma confirmação e do reconhecimento pelo adulto de que a imagem que a criança olha no espelho é efetivamente a dela própria" (idem). Retornando novamente a Lacan, esclarece que "Lacan afirma que a verdadeira prematuração do homem é "a prematuração simbólica pela qual a criança inscreve-se no ser para o outro"" (ibidem).

Pereira prossegue em sua abordagem a respeito das consequências radicais oriundas das condições do "pequeno homem" ao nascer - o desamparo e a dependência - associadas à linguagem segundo Lacan: “A dimensão propriamente psicanalítica, ou seja, a incidência dessa condição originária de impotência e dependência em relação ao Outro na constituição da subjetividade será explicitada por Lacan alguns anos mais tarde. Em 1951, afirma "a realidade da miséria fisiológica própria aos primeiros meses da vida do homem" implica uma situação de dependência aparecendo como significante no indivíduo. Ou seja, ela ganha importância não por causa da realidade psicológica que ela implica, concebida como uma etapa ou um estágio, mas como elemento suscetível de inscrever-se enquanto significante na história dos eventos psíquicos do sujeito" (Pereira, 1999, p. 228).

É importante marcar que, juntamente a este caráter unificante e apaziguador do Outro, existe uma dimensão deste intimamente relacionada à perda e à solidão. Flanzer (2004) sinaliza esse outro aspecto, trazendo uma 
novidade em relação ao que fora pontuado até aqui. "A presentificação do Outro traz como corolário a própria falta deste Outro, designando a falta particular do sujeito e remetendo-o a uma solidão inaugural, que certamente irá retornar em diversos momentos de sua vida. Lembrando o que Lacan postula em "O Estádio do espelho", o estádio constitutivo do sujeito, conferido a ele pelo Outro, efetivase como sendo também o lugar da perda deste Outro. No momento em que o Outro lança sobre o sujeito a possibilidade de fazer dele uma unidade, ao designar: "você é Fulano", neste mesmo momento o sujeito passa a experimentar sua radical alteridade. Pois, ao constituir-se como Fulano, se Fulano ele é, já não pode mais contar com Beltrano, e nem com Cicrano, como partes coladas de si" (Flanzer, 2004, p. 95).

A partir do que abordamos nessa seção, observamos o quão necessário para a sobrevivência física e psíquica é o contato do humano com outro humano. Essa é uma ideia-chave para o que seguiremos desenvolvendo na tese, que nos será extremamente útil quando formos refletir sobre as situações em que a comunicação virtual se dá entre seres falantes e máquinas, ou seja, quando "do lado de lá" não há um outro humano. Não podemos, portanto, perder de vista que "o estudo de Freud e o de Lacan coincidem e destacam algo fundamental da natureza humana, a saber: o ser humano se compreende ou se realiza, no sentido forte do termo, só quando é colocado em cena, no espetáculo, no confronto com o outro" (Forbes, 2011, p. 132). Destacamos dessa afirmativa de Forbes o termo "confronto", que nos ressoou como algo que aponta para a dupla dimensão da relação com a alteridade, também trabalhada anteriormente, a qual nos será igualmente útil nas discussões subsequentes da tese, relativas ao laço com o outro na era da internet.

Fecharemos essa seção aludindo a seu título - "do desamparo à dependência" - visando reforçar a existência dessa passagem que se dá em cada um de nós, também passível de ser nomeada como "da solidão ao laço" ou da "fragilidade à presença". Recortamos essa última referência de uma passagem de Birman (1997), bastante apropriada para trazer essa ideia que queremos deixar bem demarcada. Vejamos: "A fragilidade humana, que permite dar a vida a um outro e que possibilita a transmissão das pulsações, revela ao sujeito o seu estatuto de mortalidade e finitude. O desejo de criar uma outra vida, a partir de suas entranhas, indica que o sujeito reconhece a sua fragilidade e que esta é 
inultrapassável. Porém, revela também o quanto o outro é fundamental para o sujeito, o quanto é necessário compartilhar com aquele essa fragilidade quebradiça e de aquecê-la com a sua presença" (Birman, 1997, p. 224). Novamente vemos aqui a dupla-face do outro, o papel complexo que opera em nossas vidas, já que, ao mesmo tempo em que nos aquece e nos permite compartilhar e transmitir, não anula nossa fragilidade e nossa finitude.

Enfim, o que dessa solidão aponta para o movimento de fazer laço com o outro? Seguiremos as coordenadas de Lacan, segundo as quais, é por um vazio na constituição do sujeito que fazemos laço com nossos semelhantes e nos dirigimos ao Outro. É o que nos apontam as passagens a seguir, de distintos autores: "A partir deste ponto estrutural em nós, cada um dará sentidos e tecerá histórias próprias, a partir de nossas posições singulares" (Azevedo, 2007, p. 228). "O tema da solidão não deixa de evocar, pelo seu suposto contrário, a teoria 'do parceiro"” (Cunha, 2016, p. 49). "Se há essa solidão estrutural dos sujeitos, se essa verdade os caracteriza e os faz funcionar de modo singular, tal condição é que lhes possibilita formas de estabelecimento de laços sociais" (Ferrari, 2008, p. 18). Naparstek (2014) destaca que, ao longo de seu ensino, Lacan introduziu diferentes tipos de solidão, dentre elas "uma solidão que faz laço": "O ponto de partida é que não se pode pensar o sujeito sem o Outro. Quer dizer, se há sujeito, supomos o Outro e, portanto, seria extremo e contraditório falar da solidão do sujeito" (Naparstek, 2014, p. 378).

\section{6) O laço com o outro}

uma nova forma de laço social com os outros, tão sós quanto ele mesmo.

Elisa Alvarenga, A solidão

Intensamente envolvida com a pesquisa desta tese, me peguei, certo dia, conversando a respeito do tema com uma criança de cinco anos. Falávamos sobre esse hábito tão comum em nosso cotidiano, das pessoas usando computadores ou mexendo nos celulares freneticamente. Perguntei-lhe então porque ela achava que isso acontecia, ao que me respondeu, depois de parar uns minutos para pensar: 
“As pessoas ficam no computador pra descansar um pouco. Porque ficar o tempo todo com o outro cansa!".

A hipótese da menina, simples e pertinente, nos pareceu uma bela introdução para o que desenvolveremos nesse tópico. Sintetiza o que, de forma bem mais complexa e detalhada, nos trouxeram Freud e Lacan em suas reflexões acerca dos relacionamentos humanos, ponto em que entraremos agora. Mas, antes de focarmos nisso, gostaríamos de relatar mais um pequenino acontecimento ocorrido paralelamente à escrita propriamente dita da tese, que também colabora para a discussão teórica a que nos propomos. Circulando por uma livraria, passando os olhos pela bancada dos destaques, nos chamou a atenção um livro da série "The school of life", cujo título era "Relacionamentos" (Ed. Sextante, 2018). Já em sua apresentação pescamos a seguinte frase: "Poucas coisas nos prometem mais felicidade do que nossos relacionamentos - e poucas nos trazem tanto sofrimento e frustração". Estamos, portanto, diante de um paradoxo, no qual mergulharemos agora, a fim de compreendê-lo mais a fundo. Através da psicanálise exploraremos essa dimensão paradoxal do vínculo humano, visando entender como os relacionamentos têm, ao mesmo tempo, o poder de mitigar nossas angústias e de ser nossa maior fonte de sofrimento.

Em linhas gerais, o que tanto Freud quanto Lacan perceberam através de suas análises clínicas e de suas observações da cultura é que a vida relacional das pessoas é repleta de percalços e entraves. Não há como ocorrer a superação do conflito humano e no campo da interação entre as pessoas este se manifesta de forma acentuada. Se por um lado (como já vimos nesse capítulo) Freud constata a necessidade de proteção através do amor, por outro sublinha o quanto amar é arriscado e por isso mesmo tem grandes chances de nos machucar. A visão que tem a respeito de nossos semelhantes ajuda-nos a compreender essa complexidade, o que se evidencia em assertivas como essa: "o outro enquanto auxiliador $e$ adversário" (grifo nosso) (Freud, 1921/2011, p. 14). Se não temos como saber com certeza qual dessas facetas do parceiro - seja um namorado, um amigo, um vizinho, um colega de trabalho, um internauta com quem teclamos irá comparecer em cada encontro, a cada troca, não é difícil concordar com a dubiedade localizada por Freud nesse contexto.

As considerações de Freud e de Lacan a respeito da sexualidade humana são também fundamentais para entendermos esse ponto. Segundo eles, o sexual 
porta um impossível de saber, já que não há inscrição sobre o sexo no inconsciente. Essa falha no saber sobre o sexo constitui, portanto, um ponto traumático. Dessal (2017) apresenta assim esse ensinamento proveniente de Freud: "se o sexo desempenha um papel tão importante em nossa vida, é porque o encontro com o desejo é sempre traumático, e não há maneira de escapar ao trauma da colisão entre corpo e linguagem” (Bauman; Dessal, 2017, p. 126). Essa concepção do sexual enquanto traumático leva Lacan a formular a ideia de um "encontro troumático 5 com o Outro sexo" (Seminário 21, proferido no ano de 1973). Em seu ensino voltará a isso em diversos momentos, apresentando a mesma ideia de modos variados. Por ora selecionamos as seguintes passagens: "Que o que Freud demarcou daquilo a que chama sexualidade faça um furo no real (...) ninguém escapa ileso" (Lacan, 1974/2003, p. 558); "Não ter domínio sobre o sexual fala disso. (...) a relação de través que separa o sujeito do sexo" (Lacan, 1960/1998, p. 813).

O que desejamos salientar sobre este ponto é que, para a psicanálise, o sexual é sempre traumático. Como mostra Flanzer (2004), a teoria psicanalítica da sexualidade nasce da constatação da existência de um trauma psíquico, marcando uma defasagem irrecuperável entre o sujeito e seu objeto. (Flanzer, 2004, p. 64). Assim, complementa a autora, a dimensão erótica "instaura um abismo entre o que o sujeito destina ao objeto, no intuito de que este lhe corresponda, e aquilo que dali lhe retorna, sempre em defasagem. A sexualidade humana imprime no sujeito a marca do impossível da complementaridade, numa definitiva diferença em relação ao reino animal" (Flanzer, 2004, p. 62).

Dessa constatação de que há algo que escapa em toda tentativa de endereçamento de um sujeito a outro, se pode inferir que o campo dos relacionamentos é o reino do mal-entendido. Lacan não deixa dúvidas quanto a isso, como podemos perceber em colocações como essa: "No decorrer de um discurso intencional em que o sujeito se apresenta querendo dizer alguma coisa, produz-se algo que ultrapassa seu querer, que se manifesta como um acidente, um paradoxo, ou até um escândalo" (Lacan, 1957-1958/1988, p. 54). Quando buscamos nos comunicar com alguém, junto à possibilidade de transmitir uma

\footnotetext{
${ }^{5}$ Em francês esse termo comporta o sentido mais evidente de "traumático", mas também inclui em seu interior a palavra "trou", que significa buraco ou furo. A invenção de Lacan visa, assim, ressaltar a presença de um furo no encontro com o outro.
} 
mensagem caminha sempre o risco de não ser bem compreendido, de haver um ruído na comunicação. Até porque, há algo no dizer que escapa ao próprio sujeito que o enuncia. Nesse sentido, parece-nos evidente que no universo cibernético, nas situações em que os internautas usam a rede para falar uns com os outros, pululam mal-entendidos. É como uma brincadeira de telefone sem fio levada à milésima potência! Entraremos nessa reflexão no próximo capítulo, mas abriremos aqui um parêntese para trazer uma pequena vinheta de nossa clínica que ilustra tal fenômeno.

Ana é uma jovem que experimenta os dilemas do sujeito contemporâneo que têm à disposição os novos recursos virtuais para se relacionarem no amor. Namorando à distância com um rapaz estrangeiro que conheceu quando morou uma temporada no exterior, relata à analista que "é bom e ruim" poder manter assim o vínculo com ele. Nas trocas que realizam via Whatsapp há momentos em que a angústia toma a cena, como aquele em que ela lhe pergunta o que ele fez no dia ou onde ele estava e, somente várias horas depois, ele responde, apenas com um emoticon: um símbolo de coração. A figura gera enigma, a aflige: "Isso é um eu te amo ou um cala a boca?!", pergunta-se a jovem. Dias depois, novamente a substituição de palavras por imagens (tão comum nas trocas por mensagens online) faz corte e a desconcerta: o namorado lhe revela que gosta de práticas sado masoquistas e Ana, sem saber o que responder, arrisca, lhe enviando um emoticon com a figura de um sapato de salto alto vermelho. Para sua surpresa e desapontamento, a conversa se encerra ali.

Retornando às concepções freudianas sobre os laços que estabelecemos com os outros, passamos agora para "Introdução ao Narcisismo" (1914), texto que é em parte dedicado à observação da "vida amorosa dos seres humanos" (p. 31) como uma das vias de acesso ao estudo do narcisismo. Nele encontramos essa intrigante questão colocada por Freud: "De onde vem mesmo a necessidade que tem a psique de ultrapassar as fronteiras do narcisismo e pôr a libido em objetos?" (Freud, 1914/2010, p. 29). A fim de respondê-la apresenta a ideia de uma balança energética - entre a libido do Eu e a libido de objeto - cujo funcionamento é assim descrito: "quanto mais se emprega uma, mais empobrece a outra" (Freud, 1914/2010, p. 17). Defenderá a "necessidade da psique ultrapassar as fronteiras do narcisismo e pôr a libido em objetos" (p. 29), esboçando em seguida sua resposta à questão anteriormente colocada: "A resposta derivada de nosso curso de 
pensamento seria, mais uma vez, que tal necessidade [de pôr a libido em objetos] surge quando o investimento do Eu com libido superou uma determinada medida. Um forte egoísmo protege contra o adoecimento, mas afinal é preciso começar a amar, para não adoecer, e é inevitável adoecer, quando, devido à frustração, não se pode amar" (p. 29). Junto a isso, acrescenta que "na vida amorosa não ser amado rebaixa o amor próprio, enquanto ser amado o eleva" (Freud, 1914/2010, p. 45).

"Psicologia das massas e análise do eu" (1921) reforça essa ideia, através de postulações como essas: "tal limitação do narcisismo pode ser produzida apenas por um fator, pela ligação libidinal a outras pessoas. $\mathrm{O}$ amor a si encontra limite apenas no amor ao outro, amor aos objetos" (Freud, 1921/2011, p. 58); “É o amor que atua como fator cultural, no sentido de uma mudança do egoísmo em altruísmo" (p. 59). Dito de outro modo: "o amor refreia o narcisismo, e poderíamos demonstrar que em virtude disso tornou-se fator de cultura" (p. 86). Observamos então que nesse texto Freud promove uma aplicação do conceito de narcisismo e seus desdobramentos para a análise do social. Para ele, o indivíduo isolado é uma ficção insustentável e a psicanálise lida com um sujeito que só pode ser concebido a partir de suas relações com os outros. O caráter necessário do vínculo humano é enfatizado e este laço será pensado como pertencendo à ação da libido. A vida do sujeito deve ser considerada como fenômeno social, sendo os laços sociais caracterizados como vínculos libidinais. A libido é a grande força de atração dos grupos, ou seja, os indivíduos se unem através de "ligações libidinais" (p. 56).

Gostaríamos de retomar a menção feita acima à "mudança do egoísmo em altruísmo", que nos leva a um debate fundamental travado por Freud a respeito de sermos ou não dotados de um instinto gregário. Quanto a isso, sua posição é bastante clara: "Por muito tempo, então, nada se percebe de um instinto gregário ou sentimento de massa na criança" (Freud, 1921/2011, p. 81). Assim, o movimento de fazer laços não é inato, natural, primário, é algo que construímos. Freud não interpretará a angústia da criança ao ser deixada só como manifestação de um instinto gregário inato. Oferece a tal cena outra interpretação: trata-se de uma angústia relacionada à mãe e depois a outras pessoas familiares. "A angústia da criança pequena sozinha não é atenuada tampouco ao avistar outro indivíduo qualquer "do rebanho", mas sim, ao contrário, despertada pela aproximação de tal 
“estranho"” (p. 81). Há então uma seletividade no campo do amor, o que reforça a célebre oposição de Freud ao preceito religioso do amor universal. Além disso, voltamos a observar aqui aquela ideia de que a presença do outro tem o potencial de assustar, de produzir angústia.

A parábola dos porcos espinhos - referência de Schopenhauer presente na obra freudiana - nos fala dessa delicadeza nas relações interpessoais. Uma vez mais vemos presentificada a dor oriunda do contato com o outro coexistindo com um convite ao aconchego, que também podemos experimentar a partir desse contato. Freud recorre à célebre alegoria do filósofo alemão para ilustrar o que vinha teorizando em "Psicologia das massas" a respeito "do modo como os seres humanos em geral se comportam afetivamente uns com os outros" (Freud, 1921/2011, p. 56). No corpo de seu texto, dá destaque ao fato de que "nenhum deles aguenta uma aproximação muito íntima do outro" (idem). Em nota, transcreve o trecho da obra de Schopenhauer, do qual destacamos o final: “impelidos de um sofrimento para o outro, até acharem uma distância média que lhes permitisse suportar o fato da melhor maneira" (ibidem). Freud prosseguirá então com uma postulação eminentemente definidora do saber psicanalítico sobre os laços afetivos: "Conforme o testemunho da psicanálise, quase toda relação sentimental íntima e prolongada entre duas pessoas contém um sedimento de afetos de aversão e hostilidade" (Freud, 1921/2011, p. 56).

Antes de aprofundarmos essa ideia, desejamos explorar um pouco mais a imagem schopenhaueriana, pela riqueza que comporta, a qual inspirou diversos autores. Com ela aprendemos que os homens são como os porcos-espinhos da parábola: precisam encontrar uma boa distância entre eles para não morrerem de frio num dia gelado de inverno e obterem calor. Caso contrário, junto ao aquecimento proveniente do contato com o outro, experimentarão a dor de espetarem-se mutuamente. Devem aprender, portanto, a estar junto separadamente, na tentativa de dar conta do mal estar. "Se vive na solidão, o frio espreita e, então, o porco espinho busca o montão, junto aos outros. A proximidade, por outro lado, produz furadas, o animal se fere e torna a separar-se" (Vilà-Barcelona, 2009, p. 33).

A partir da leitura bem humorada de Flanzer (2004) aprendemos que o laço pensado a partir de Freud tem relação com o que nos revela o chiste popular sobre o modo como dois porcos espinhos fazem amor. "Com muito, muito 
cuidado...”. Seguindo em suas reflexões, nos diz Flanzer: "São inumeráveis os vai-e-vem desse espinhoso movimento chamado amor - guardada a sua porção odiosa... Ao sujeito, está lançada a mesma sorte que a dos porcos-espinhos: ao acalentar-se junto ao outro, depara-se com a brasa incômoda deste ardente fogo, proveniente da proximidade larval que faz despontar a sua mais incinerada hostilidade. Todavia, ao afugentar-se deste calor, ao procurar evitá-lo ou elidi-lo, corre o risco de congelar-se, solidificando seu desalento num derradeiro entorpecimento: a consumação, por excelência, da impotência psíquica" (Flanzer, 2004, p. 150).

Karnal (2018), em seu mais recente livro, inteiramente dedicado ao assunto, afirma de saída que o dilema do porco espinho é o dilema humano. "Somos uma espécie de porco espinho, pensava Schopenhauer. O frio do inverno (ou da solidão) nos castiga. Para buscar o calor do corpo alheio, ficamos próximos dos outros. Efeito inevitável do movimento: os espinhos nos perfuram e causam dor (e os nossos a eles). O incômodo nos afasta. Ficamos isolados novamente. O frio aumenta e tentamos voltar ao convívio com o mesmo resultado. A metáfora do filósofo alemão trata do dilema humano: solitários, somos livres, porém passamos frio. A dois ou em grupos as diferenças causam dores. Teríamos de achar uma distância segura, que trouxesse o calor necessário e evitasse o ataque. Qual a barreira mínima entre dois humanos espinhentos? Não existe uma resposta exata, e erramos com frequência no binômio só-acompanhado" (Karnal, 2018, p. 09).

Recorrendo a outras referências Karnal prossegue suas reflexões e citações, dentre as quais destacamos aquelas que se aproximam de forma exemplar ao tema central de nossa tese: "Fugir ou buscar o isolamento, encontrar ou perder o amor é o eixo definidor da própria cultura humana. O poeta Rainer Maria Rilke definiu que o amor era apenas duas solidões protegendo-se uma à outra. Quase podemos ver a ligeira ironia contida na afirmação: amor é solidão compartilhada" (p. 13); "Tudo de bom e de ruim vem do jogo de contrastes entre companhia e solidão" (p. 15); Para o cineasta Orson Welles, escritores escolhem falar da solidão em suas obras, pois “o homem nasce só, vive só e morre só. O amor e a amizade dão-nos a ilusão, momentaneamente, de não estarmos sós” (p. 58). É importante comentar ainda pontos de distanciamento entre o ponto de vista deste autor e o viés psicanalítico de pensamento sobre o humano. Tal 
diferenciação nos parece uma forma interessante de frisar os conteúdos que desejamos transmitir com esse estudo. Ali onde afirma que "solitários somos livres", diríamos que solidão e liberdade não coincidem. Quanto a uma suposta distância segura entre dois, não há meios de encontrá-la. Trata-se de um exercício constante, em que a sensação de segurança plena é rara e, quando (e se) existe, certamente é fugaz, passageira.

Vemos em Karnal e "seu dilema" uma oportunidade de abrir um parêntese nessa seção especificamente dedicada ao laço com o outro, visando travar um diálogo entre essa temática e a solidão estrutural. Se abrimos esse capítulo afirmando justamente que essas duas dimensões da vida estão em continuidade, é preciso reforçar essa posição, discorrendo sobre os emaranhados que se formam entre elas. Tomemos, pois, a pergunta agora levantada por Karnal como um convite a esse exercício: “Alguém, alguma vez, já deixou de estar sozinho ou somente criamos opiáceos, paliativos como o casamento, para ocultar a realidade assustadora de que estamos irremediavelmente sós?" (Karnal, 2018, p. 31). Dialogando com Karnal, diríamos que não deixamos nunca de estar sozinhos, justamente pelo fato que ele mesmo aponta, de que a solidão estrutural é irremediável. Mesmo no casamento ou no interior de qualquer tipo de laço afetivo há solidão. A conexão com outra pessoa, o bate-papo virtual ou o encontro com outro alguém não elimina o fato de sermos sós. As vivências coletivas carregam solidão e, a esse respeito, Cazuza é esclarecedor, ao trazer-nos a bela imagem de uma "solidão a dois de dia, faz calor depois faz frio".

Seguindo por esse viés da arte, vale comentar ainda que no seio de uma experiência solitária, em que se ausenta a companhia de outra pessoa, pode haver conexão, por exemplo, com um livro, com uma tela, com a música. A fruição da natureza - de suas belas paisagens, das sensações provenientes de um mergulho no mar, da brisa no rosto - tem também o poder de afastar o sujeito da sensação angustiante de estar cruamente deparado com sua condição solitária. Afastar, distrair, alimentar, sem, contudo, eliminar ou tamponar.

Outra forma de explorar o "binômio só-acompanhado" acima mencionado por Karnal é pensarmos a respeito do provérbio "antes só do que mal acompanhado" junto à música "Me recuso", composta por Rita Lee e Lee Marcucci, da qual destacamos esse trecho: 


\section{Me recuso a ficar só \\ Antes mal acompanhada \\ Pelo menos eu tenho com quem brigar \\ Ou talvez alguém pra amar}

\section{(Rita Lee / Lee Marcucci)}

Vemos no provérbio popular e nas palavras desses músicos possibilidades múltiplas e até mesmo contrárias de pormos em prática esse binômio. A dificuldade comparece em ambas as experiências - no estar só e no estar acompanhado. Do encontro com o companheiro brotam tanto amor quanto brigas. E a satisfação que pode ser extraída tanto de um quanto de outro depende da singularidade de cada um. Mais uma vez, a menção à internet nos parece rica nessa discussão, por se tratar de um campo novo e bastante ilustrativo disso a que estamos nos referindo. $\mathrm{Na}$ internet podemos ficar sozinhos (nós e os gadgets), podemos amar, podemos brigar.

Do amor e das brigas, voltemos então às postulações freudianas relativas ao laço com o outro, esmiuçando agora a questão da aversão e da hostilidade. Entraremos nisso a partir do fenômeno da ambivalência afetiva, mencionado por Freud 6 em "Psicologia das Massas" de 1921. É algo que ocorre "quando a hostilidade se dirige para pessoas normalmente amadas" (Freud, 1921/2011, p. 57). Essa mistura entre amor e ódio está ligada à nossa prontidão para o ódio e para a agressividade, o que remete ao fato destes sentimentos humanos terem, segundo Freud, um caráter elementar. Tais ideias foram por ele inicialmente apresentadas no ano anterior, em "Além do princípio de prazer" (1920), texto de virada em sua obra por conta justamente da radicalidade de ideias como essa.

A afirmativa de que o instinto gregário não é primário pode ser entendida agora da seguinte forma: o sentimento social é uma inversão de uma hostilidade original. Nas palavras de Freud: "O que depois aparece na sociedade como espírito comunitário, esprit de corps, não desmente sua procedência da inveja original” (Freud, 1921/2011, p. 82); “O sentimento social repousa, portanto, na inversão de um sentimento hostil em um laço de tom positivo, da natureza de uma identificação" (p. 83); "Ousemos então corrigir o enunciado de Trotter, segundo o

\footnotetext{
${ }^{6}$ Vale comentar que a ambivalência afetiva aparecera anteriormente na obra freudiana, em textos como "As pulsões e seus destinos" de 1915 e "Além do princípio de prazer" de 1920, dentre outros.
} 
qual o homem é um animal de rebanho, dizendo que ele é antes um animal de horda, membro individual de uma horda conduzida por um chefe" (idem).

São afirmações que remetem ao conceito de pulsão de morte formalizado no ano anterior e que apontam para as considerações sobre o mal-estar na civilização do texto de 1930 . Destaca-se aqui a novidade psicanalítica segundo a qual a inclinação para a agressão perturba o relacionamento com o próximo. $\mathrm{Na}$ base de toda relação de afeto entre as pessoas reside uma disposição original à agressividade. Nos momentos em que Freud faz afirmações como essas, a desilusão quanto à possibilidade de superar o mal radical que caracteriza o laço social fica evidente. Desde 1915, vai nos dando notícias do quão desafiador é para os homens participar de uma comunidade civilizada. Em nome do convívio e da civilidade exige-se a renúncia à satisfação das pulsões, fazendo-se necessário um trabalho de "transformar os impulsos egoístas sob a influência do erotismo" (Freud, 1915/1996, p. 292). A reflexão sobre o ser humano ser 'bom' ou 'mau' (a partir da qual Freud aponta para a coexistência de ambas as inclinações em todos nós) e a afirmação de Freud de que "não existe essa erradicação do mal" (p. 290) vão quebrando qualquer possibilidade ingênua de se pensar na harmonia entre os homens.

"O mal-estar na civilização" (1930) coroa a descrença de Freud na felicidade proveniente da vida em comunidade, ao abordar a miséria humana na sociedade e definir o mal-estar como algo ineliminável. Logo no início do texto Freud pontua que a noção que os homens possuem a respeito de seu vínculo com o mundo não é imediata. Pensar que se está desde o início orientado para isso é algo bem estranho para a psicanálise (Freud, 1930/2010, p. 16). A 'civilização' distingue nossa vida dos antepassados animais e serve a dois intuitos: proteger os homens contra a natureza e ajustar seus relacionamentos mútuos. Ou seja, os relacionamentos sociais têm que ser regulados pelo elemento de civilização, sendo esta construída sobre a renúncia pulsional, cerceando o gozo sexual e fazendo com que a agressividade seja introjetada, assumida pela parte do ego que se coloca contra a outra, formando o superego ou consciência moral.

Tal movimento de freio à agressividade contra o outro se deve ao desamparo originário dos seres humanos, sobre o qual falamos anteriormente. Pelo medo da perda do amor se renuncia a certas satisfações. Nas palavras de Freud: "O ser humano deve ter um motivo para se submeter a essa influência 
externa. Podemos enxergá-lo no desamparo e na dependência dos outros, e a melhor designação para ele seria medo da perda do amor. Se perde o amor do outro, do qual é dependente, deixa também de ser protegido contra perigos diversos, sobretudo expõe-se ao perigo de que esse alguém tão poderoso lhe demonstre a superioridade em forma de castigo". Em seguida, equivalerá "medo da perda do amor, medo "social"” (Freud, 1930/2010, p. 94). A partir dessa postulação freudiana percebemos que, mesmo não sendo animais gregários temos fortes motivos para desejarmos sermos amados. Apesar do amor não ser instintivo nem primário é imensa a força que nos atrai ao outro, que nos impele ao enlaçarse. A necessidade humana de amor como dado fundamental para a interiorização da moral fora anteriormente abordada por Freud em 1921, quando reafirmou o que escrevera no "Projeto" de 1895: "o cerne da chamada consciência moral consiste no "medo social"" (Freud, 1921/2011, p. 21). Sobre isso, esclarece Mograbi (2009): "Na ausência de qualquer gregarismo inato, é a necessidade de amor que nos compele em direção ao outro" (Mograbi, 2009, p. 36).

Outro ponto de destaque no texto de 1930 é a apresentação por Freud de uma de suas mais fortes concepções sobre o sofrimento humano. "O sofrer nos ameaça a partir de três lados: do próprio corpo, do mundo externo e das relações com os outros seres humanos", sendo que, "o sofrimento que se origina desta fonte nós experimentamos talvez mais dolorosamente que qualquer outro" (Freud, 1930/2010, p. 31). Complementa sua colocação caracterizando ainda o sofrimento proveniente desta direção como "fatidicamente inevitável" (idem) A fonte social é a que mais nos impacta, dá trabalho. A fragilidade da relação com o outro fica evidente, dado que é uma relação que só pode ser concebida como repleta de riscos e carente de garantias. É preciso ainda sublinhar que se esse sofrimento que experimentamos na relação com outro ser humano é inevitável, tentativas de se isolar portarão sempre alguma falha. Sendo assim, adolescentes que se trancam em seus quartos e vivem imersos em games ou adultos que vivem majoritariamente no anonimato nas redes e evitam o convívio nas ruas não deixam de ser acometidas pelas mazelas provenientes dessa fonte de sofrimento. Sofrem de um modo distinto, mas sofrem.

A angústia diante da falta de amor do objeto é mais uma situação que demonstra o lado problemático do laço com o outro. Na lista que constrói sobre quais seriam as "técnicas da arte de viver" inclui o amor e reflete a seu respeito, 
pontuando as complexidades intrínsecas a essa experiência. $\mathrm{O}$ que acontece com aquele que "não se afasta do mundo exterior, agarra-se aos seus objetos pelo contrário e obtém felicidade de uma relação afetiva para com eles" (Freud, 1930/2010, p. 38)? Segundo Freud, muitas coisas podem acontecer, da felicidade à desproteção. Certamente ficamos expostos quando escolhemos essa técnica na busca por uma vida mais feliz. Na raiz desse impulso de se lançar no campo do amor está o fato de que "essa atitude psíquica é familiar a todos nós", "nada mais natural do que insistirmos em procurar (a felicidade) no mesmo caminho em que a encontramos primeiro" (Freud, 1930/2010, p. 39).

Logo em seguida, irá acentuar a faceta amarga aí presente: "O lado frágil dessa técnica de vida é patente; senão, a ninguém ocorreria abandonar esse caminho por outro. Nunca estamos mais desprotegidos ante o sofrimento do que quando amamos, nunca mais desamparadamente infelizes do que quando perdemos o objeto amado ou seu amor" (idem). Em seguida, adverte-nos novamente sobre os perigos do amor: "assim, ele se torna dependente, de maneira preocupante, de uma parte do mundo exterior, ou seja, do objeto amoroso escolhido, e fica exposto ao sofrimento máximo, quando é por este desprezado ou o perde graças à morte ou à infidelidade. Por causa disso, os sábios de todas as épocas desaconselharam enfaticamente esse caminho; não obstante, ele jamais deixou de atrair um grande número de seres humanos" (Freud, 1930/2010, p. 64). A aposta no amor assim descrita, como algo atraente e preocupante, nos remete uma vez mais ao dilema humano análogo ao dilema do porco espinho.

Ao mesmo tempo em que reconhece "o amor como um fundamento da cultura" (Freud, 1930/2010, p. 64) critica veementemente o amor universal. O mandamento religioso "ama teu próximo como a ti mesmo" (p. 73) seria um dos esforços supremos feitos para haver civilização, já que as paixões pulsionais são mais fortes que os interesses razoáveis. Ao criticar esse preceito religioso, afirma que o que está "por trás disso, que as pessoas gostam de negar, é que o ser humano não é uma criatura branda, ávida de amor, que no máximo pode se defender quando atacado, mas sim que ele deve incluir, entre seus dotes pulsionais, também um forte quinhão de agressividade" (Freud, 1930/2010, p. 76). Parte da ideia filosófica de que "o homem é o lobo do homem", para conceber "o ser humano como uma besta selvagem que não poupa os de sua própria espécie" (p. 77). A explicação para tal, segundo a psicanálise, reside na "existência desse 
pendor à agressão (...) (que) é o fator que perturba nossa relação com o próximo" (idem).

Nesse contexto, o mandamento bíblico é visto por Freud como uma formação psíquica reativa que "se justifica pelo fato de nada ser mais contrário à natureza humana original" (p. 78). A agressividade, "esse indiscutível traço da natureza humana", "constitui o sedimento de toda relação terna e amorosa entre as pessoas" (p. 80). Vemos assim, que em "O mal-estar” de 1930, Freud nos oferece uma leitura da cultura que parte das formulações que apresentara no "Além do princípio de prazer" de 1920. As passagens que selecionamos a seguir embasam esse ponto, pois nelas Freud explicita o conceito de pulsão de morte através de suas expressões sociais. Citando o autor: "Já não entendo que pudéssemos ignorar a onipresença da agressividade e destrutividade não erótica" (Freud, 1930/2010, p. 87); "tendência inata do ser humano para o "mal”, para a agressão, a destruição, para a crueldade, portanto" (p. 88); “o maior obstáculo à cultura, o pendor constitucional dos homens para a agressão mútua" (p. 118); "a hostilidade de um contra todos e todos contra um" (p. 90); "Cada um de nós vive o momento em que deixa de lado, como ilusões, as esperanças que na juventude depositava nos semelhantes, e aprende o quanto a vida lhe pode ser dificultada e atormentada por sua malevolência" (p. 78). O que essas passagens demarcam com muita força é que, para além do sofrimento proveniente do risco de perder um amor, decorrente da possibilidade sempre presente de um rompimento afetivo, estamos expostos ao ódio dos outros seres humanos.

Abrimos aqui um novo parêntese, pois nos parece um momento oportuno de nosso texto para mencionarmos o fenômeno dos haters na internet, assim como as tentativas de regulação das $\operatorname{redes}^{7}$ de que se têm falado bastante nos últimos anos. Este termo, habitualmente utilizado em inglês, refere-se àqueles internautas odientos ou odiadores que postam comentários de ódio ou crítica agressiva sem muito critério. Suas ações repercutem negativamente para as pessoas atacadas, as quais se sentem vítimas de um ato de cyberbullying (o bullying virtual) ou de um assédio virtual. Consideramos que a visão de Freud a respeito da

\footnotetext{
${ }^{7}$ Por conta do recorte que escolhemos para essa pesquisa não nos aprofundaremos nessas temáticas. Consideramos que abordá-las poderia render outra tese, tamanha a riqueza de aspectos que o assunto envolve. Ainda assim, optamos por apontar o fenômeno, dada a presença gigantesca que ganhou na contemporaneidade, interferindo de forma importante nos âmbitos interpessoais e políticos. Essa correlação que aqui apontamos, entre os haters e as concepções freudianas acerca da natureza humana, pode, quem sabe, inspirar outros pesquisadores em novas investigações.
} 
agressividade inerente aos homens exposta acima serve como boa chave de leitura desse fenômeno contemporâneo. Além disso, "a insuficiência das normas que regulam os vínculos humanos na família, no Estado e na sociedade" (Freud, 1930/2010, p. 43) já constatada por Freud em 1930 a partir de suas observações dos fenômenos culturais a sua volta, parece seguir vigente. Ao afirmar ser necessária para um convívio civilizado a "regulamentação dos vínculos dos homens entre si” (p. 49) Freud estava dizendo que esses vínculos precisam ser regulados, pois tendem ao caos, à destruição. "Não havendo essa tentativa, tais relações estariam sujeitas à arbitrariedade do indivíduo" (p. 56), complementa o autor. Essa exigência de leis que funcionem como mediação entre as pessoas é mais um elemento que testemunha o quanto o laço com o outro requer esforço, é um trabalho que despende energia.

Tal ideia já havia sido apresentada em "O futuro de uma ilusão" (1927), texto que dialoga com "Psicologia das massas" e é uma espécie de preâmbulo ao "Mal-estar". Ali Freud salienta que são numerosas "as instituições necessárias para regulamentar as relações entre os indivíduos" (Freud, 1927/2014, p. 233) e que, mesmo assim, "não se constata seguramente um progresso igual na regulação dos assuntos humanos" (p. 234). Justifica essa dificuldade mencionando nossas tendências destrutivas, chegando a caracterizar os homens como "antissociais e anticulturais" (p. 235). A esse respeito, explica-nos Freud: "todo indivíduo é virtualmente um inimigo da cultura. É digno de nota que os seres humanos, embora incapazes de viver no isolamento, sintam como um fardo os sacrifícios que a civilização lhes requer, para tornar possível a vida em comum” (p. 233).

É interessante nessa passagem a presença desses dois aspectos conflitantes: por um lado somos antissociais, por outro, isolarmo-nos não é uma opção. É essa, pois, a luta permanente do ser humano no âmbito relacional. Nesse sentido, como construir meios próprios de se haver com esse desafio, de se virar em meio a esse drama? A criação de salas de bate-papo virtuais, de redes sociais via internet ou de aplicativos de encontro não seriam uma oferta a mais para lidarmos com isso? Quais as possíveis articulações entre sermos antissociais e o sucesso avassalador das redes sociais? Socializar em demasia nos retira essa característica observada por Freud? Ou, ao contrário, a proliferação de discussões odiosas e do cyberbullying reforçam isso que a psicanálise pensa a respeito do humano? Com relação ao isolamento mencionado por Freud, quais as múltiplas 
formas de aparição desse comportamento na Era da internet? Através da relação com os gadgets tecnológicos estaríamos nos tornando menos "incapazes de viver no isolamento"? A internet nos habilita a prescindir do outro em nossas vidas? Do nosso ponto de vista, são importantes questões a serem debatidas, às quais retornaremos no próximo capítulo.

Para avançarmos nas reflexões sobre o vínculo humano e sua precariedade, recorreremos ao livro "O laço social na teoria freudiana" (Mograbi, 2009), por ser bastante esclarecedor e capaz de sedimentar bem o que aprendemos com Freud até aqui. $\mathrm{O}$ autor se dedica a investigar as diversas considerações que o saber psicanalítico produziu acerca das seguintes questões: "no que diz respeito à relação do sujeito com o outro, o que nos liga? Qual o estatuto das relações humanas? Em que se sustenta o vínculo entre as pessoas?” (Mograbi, 2009, p. 17). A dubiedade própria a essa dimensão de nossas vidas perpassa a argumentação do livro e se evidencia em passagens como essa: "Se nossos relacionamentos são fonte de mal-estar, também são o traço mais característico da experiência humana" (Mograbi, 2009, p. 21). A partir da constatação relativa à fragilidade do laço social, o autor aposta, junto a Freud, na incerteza como única via possível de se pensar as relações entre os sujeitos, afirmando que "Freud considera criticamente o vínculo humano" (p. 51). É uma forma de vínculo "não natural, eventualmente agressivo, frustrante ou satisfatório, enfim, impossível de ser determinado à priori" (p. 78). Por tudo isso, "o laço é acaso dos encontros e artifício da fantasia" (idem). Para Mograbi (2009), "o impacto da agressividade se faz sentir, jogando por terra qualquer pretensão de convivência harmoniosa. Há um mal-estar no laço social irredutível às condições de progresso, mal-estar do qual a marcha da modernidade não é capaz de nos proteger" (Mograbi, 2009, p. 56). Segundo a perspectiva freudiana acerca dos relacionamentos, frisa Mograbi, "não há laço social ou pacto simbólico capaz de resguardar o sujeito da ação destrutiva do outro" (Mograbi, 2009, p. 58). Enfim, ao evidenciar-se a desilusão quanto às expectativas em torno do laço social, destaca-se a brutalidade e a violência inerentes ao homem como os grandes inviabilizadores das relações humanas.

Interessa-nos também aqui a abordagem de Dessal (2017), que se refere a isso desde Freud, mas indo além. Abordando o que denominou de "a fatalidade dos laços humanos", discorre sobre "o caráter profundamente conflitivo das 
relações com nossos semelhantes e com as instituições que criamos" (Bauman; Dessal, 2017, p. 21). Lendo 'O mal-estar', vê Freud revelar ali "um terrível paradoxo: renunciar a satisfazer uma pulsão é uma condição necessária para o laço social, mas, ao fazê-lo, pagamos um preço muito alto: incorremos num sacrifício cujo resultado provoca um dano no mesmo laço social que ele contribuiu para criar. Nada pode ser construído sem certa renúncia, embora isso se transforme em fonte de sofrimento e dor" (idem, p. 118). O autor prossegue em suas enunciações incluindo o conceito de gozo em Lacan, complementando de forma interessante aspectos que trabalhamos até aqui. Em suas palavras: "Se Freud nos ensinou algo, foi que o sujeito humano pode encontrar o gozo sexual em seu próprio corpo, e, de fato, essa é a primeira e principal fonte de prazer. Não há nada no "programa humano" que tenda a uma busca natural do gozo na relação com um partenaire. O gozo, em seu mais puro desempenho, é completamente autoerótico, e o que a psicanálise procurou explicar foi de que maneira, na ausência de uma conexão sexual instintiva, o ser humano pode (e deve), apesar de tudo, renunciar parcialmente à obtenção de prazer só em seu corpo e ir ao encontro de outro" (...) “O encontro entre os sexos é algo extremamente complexo, alheio a toda definição normativa, submetido à particularidade de cada ser humano e fundamentalmente condicionado por uma estrutura simbólica e imaginária que a duras penas consegue suprir aquilo que a linguagem nos roubou: a ação instintiva" (Bauman; Dessal, 2017, p. 48).

O que vamos constatando a partir de todos esses autores é que, segundo a psicanálise, os sujeitos, enquanto seres falantes, sexuados e mortais, não têm meios para evitar completamente a angústia, isto é, não há como se relacionar, construir laços afetivos, sem a castração. Sob esse ponto de vista, a companhia não exclui a solidão e todo encontro é, ao mesmo tempo, desencontro. A fim de abordarmos esse aspecto do encontro-desencontro, aderimos à proposta de Vidigal (1998): “É preciso talvez colocar um hífen no significante encontro já que, para nós, ele carrega a marca do desencontro estrutural (o encontro se apresenta aí como sintoma, resposta a uma falta fundamental)" (Vidigal, 1998, p. 85). E somamos a ela a de outro autor, que caminha em direção semelhante. Para Mattos (1997), "existem pelo menos tantos desencontros quanto são os encontros marcados" (Mattos, 1997, p. 04); “o desencontro é o encontro marcado com o 
desencontro, espécie de estrutura disjuntiva básica" (p. 05); "experiência de desencontro fundamental: encontro com uma discordância primordial” (p. 06).

Drummond (1998) contribui na construção teórica sobre o amor, apresentando-o enquanto forma de desencontro, mas não só. A autora traz à cena elementos da teoria lacaniana que permitem a leitura de que o amor possa ser algo em que vale a pena apostar nossas fichas para lidar com a fragilidade que nos acossa. Distingue, portanto, o amor tal como o enxerga a psicanálise, do amor que sempre leva ao final feliz, repetidamente enaltecido nos contos de fadas. Vejamos: "Contrariamente ao mito do amor totalizante, não há qualquer esperança de complemento no horizonte do amor para a espécie humana. Este engano é o de aspirar ao dois para inscrever a relação de fusão dos parceiros, o "nós dois somos um”. Porém o inconsciente só conhece o um e o sujeito está por isso condenado a uma separação com o sexo. Entre o homem e a mulher existe um muro, dizia Lacan. (...) $\mathrm{O}$ amor é um artifício para saltar esse muro e vem em suplência à relação sexual. Com o amor o sujeito nomeia a solidão e sai fora do gozo do Um. O amor revela que a relação sexual, enquanto que é impossível de escrever, só pode ser captada por acaso, num encontro, encontro que não deixa nunca de passar pela prova do impossível” (Drummond, 1998, p. 145).

Em sua tese intitulada "Amor pela metade: incidências da impossibilidade na esfera do amor" Flanzer (2004) dedica-se à temática que por hora nos interessa, dando destaque justamente ao que o título por ela escolhido já menciona. Segundo ela, "para Freud, o amor só pode ser experimentado de modo incompleto. Trata-se da constatação de que, no campo dos investimentos realizados pelo sujeito, podese entrever uma divisão" (Flanzer, 2004, p. 99). Em seguida, reforça tal perspectiva, enunciando, a seu modo, o paradoxo no campo do amor: "paradoxo sobre a condição do sujeito: através do amor, ele obtém um suposto descanso, o amor é seu repouso imaginário, mas o amor é também o que o reconduz, reiteradamente, a um encontro com o impossível" (p. 111). Remetendo-se a Lacan em "O seminário, livro 4", apresenta outro conteúdo fundamental: nas experiências amorosas não há reciprocidade. Considerar uma troca absolutamente harmônica e equânime entre dois contraria toda a experiência clínica segundo Lacan. Nas palavras do autor: "De fato, a noção de um amor tão estritamente complementar, e como que destinado por si mesmo a encontrar sua reciprocidade, constitui uma evasão tão pouco compatível com uma teorização correta que os 
autores acabam por confessar que esta é uma posição ideal, senão ideativa" (Lacan, 1956-1957/1995, p. 64, op. cit. Flanzer, 2004, p. 66). Aludindo diretamente ao título de sua tese, conclui Flanzer (2004): "Pois todo amor é um amor pela metade. E entre uma metade e outra desta esfera, está o real. O real, tal como procurei classificá-lo, no decorrer desta tese, pode ser notificado na experiência do sujeito como desencontro, encontro sempre faltoso, perda, hiância, incompletude, insatisfação, angústia, estranhamento, morte, sangue, vazio, ocultamento, descerramento, feminilidade" (Flanzer, 2004, p. 195).

Consideramos importante para o embasamento teórico a que nos propomos nesse capítulo da tese que nos dediquemos agora a um estudo de " $\mathrm{O}$ seminário, livro 20" de Jacques Lacan, no qual o autor apresenta contribuições inéditas e valiosas para a discussão psicanalítica acerca do sexo e do amor e, portanto, do laço com o outro. Ideias às quais já nos referimos através de seus comentadores como a não complementaridade, a inexistência da relação sexual, a marca do impossível, o muro entre o homem e a mulher e o amor como artifício ou suplência - poderão assim ser mais bem absorvidas. $O$ que nos interessa particularmente nesse momento de seu ensino é sua abordagem sobre a falha na comunicação e os efeitos da linguagem na interação humana pelo viés do gozo e do amor. A faceta de impossibilidade presente no laço com o outro, já descrita por Freud, aparece aqui de forma literal, sem que restem dúvidas quanto à sua posição: “o de que se trata é de o amor ser impossível” (Lacan, 1972-1973/1985, p. 117); "aí há impossibilidade" (p. 198).

Uma das maneiras de versar sobre isso diz respeito à relação entre amor e demanda. Visto que "o amor demanda o amor. Ele não deixa de demandá-lo. Ele o demanda... mais ... ainda" (p. 12), conclui-se que uma satisfação plena e intocada não tem como ser atingida. É o que reforça Pereira (1999), em sua interpretação da máxima lacaniana, ao dizer que "as satisfações de pedidos de amor são fundamentalmente frustrantes, dado que o símbolo enquanto símbolo de uma ausência sempre deixa uma falta de satisfação em seu lugar: a demanda é sempre demanda de outra coisa" (Pereira, 1999, p. 231).

Dando continuidade à postulação freudiana de que todo sujeito está submetido à castração e é efeito de uma interdição ao gozo impossível, Lacan afirma não haver complementaridade entre os sexos. Da observação do desencontro do gozo do homem com o gozo da mulher, extrai seu axioma "não há 
relação sexual" (Lacan, 1972-1973/1985, p. 49). Dessa ausência, portanto, de um gozo complementar entre homens e mulheres, decorre a incomunicabilidade entre os sexos. De diversas maneiras Lacan nos informa neste seminário sobre essa falta de proporção entre homens e mulheres. Vejamos algumas delas: "não há, é impossível colocar-se a relação sexual"; "a impossibilidade da relação sexual como tal" (p. 17); "entre os sexos, no ser falante, a relação não se dá" (p. 90); "para tudo o que diz respeito à relação entre os homens e as mulheres (...) a coisa não vai” (p. 46); “Todo mundo sabe, com certeza, que jamais aconteceu, entre dois, que eles sejam só um"; "a relação sexual, esse termo que manifestamente escapa" (p. 64). "Não há relação sexual porque o gozo do Outro é sempre inadequado, enigmático" (p. 197).

A partir de Lacan, Miller apresenta uma nova formulação, que dialoga bastante com um dos objetos de estudo desta tese, a saber, o laço com o outro. Diz-nos ele: "O real do laço social é a inexistência da relação sexual" (Miller, 2016, p. 31). Tal ideia pode ser também compreendida através da seguinte formulação de Flanzer (2004): "tanto para o homem quanto para a mulher há uma falha inexorável no coração da relação sexual" (Flanzer, 2004, p. 113). Partindo desse ponto de vista, o que pensar a respeito de sites como "Par Perfeito" e "Saw you at Sinai ${ }^{8}$, que já em seus nomes aludem à complementaridade? Quais os efeitos para o sujeito contemporâneo de ofertas como essa? De que forma novidades como estas advindas com a internet modificam o laço social?

Inúmeras vezes ao longo deste seminário, Lacan recorre à metáfora da escrita para apresentar suas concepções a respeito do amor e da relação sexual. Destacamos alguns desses trechos, os quais transcrevemos a seguir: "a relação sexual não se pode escrever. (...) será para sempre impossível escrever como tal a relação sexual" (Lacan, 1972-1973/1985, p.49); “a relação sexual, vocês não poderão jamais escrevê-la" (p. 50); "relação sexual - no que esta não é de nenhum modo inscritível” (p. 107); "a relação sexual não pára de não se escrever” (p. 127). Observamos aqui uma interlocução direta com Freud (1930/2010) quando este afirma que "a sexualidade é um fato biológico que, embora de significação extraordinária para a vida psíquica, é psicologicamente difícil de apreender"

\footnotetext{
${ }^{8}$ Site de encontros frequentado por judeus ortodoxos que buscam parceiros com quem possam vir a se casar. $\mathrm{O}$ nome do site faz menção à passagem da Torá em que está escrito que, nos primórdios, todas as almas estiveram juntas no Monte Sinai, em Israel. A proposta do site seria promover o reencontro das almas.
} 
(Freud, 1930/2010, p. 70). A partir dessa metáfora da escrita, gostaríamos de propor uma reflexão a respeito do fato de que quando nos relacionamos usando a internet, o fazemos eminentemente por escrito. Será então que, com Lacan, poderíamos afirmar ser essa uma das razões para as querelas no mundo virtual? Quando não paramos de escrever, teclando ininterruptamente, damos mais oportunidade para a aparição do "não pára de não se escrever" da relação sexual?

Em "O triunfo da religião" (1974), trabalho concomitante ao "seminário, livro 20", Lacan vem reforçar sua perspectiva acerca da impossibilidade na relação sexual. Destacamos daí as seguintes passagens: "Estamos completamente separados dele. Porquê? (...) Nunca chegaremos ao cabo da relação entre esses falasseres que sexuamos como macho e esses falasseres que sexuamos como mulher. Aí, perdem-se totalmente as estribeiras" (Lacan, 1974/2005, p. 76); "para o falasser a sexualidade é sem esperança" (p. 77). Nessa mesma direção, afirma Lacan em "Radiofonia", de 1970: "na psicanálise, o homem nada sabe da mulher, nem a mulher do homem" (Lacan, 1970/2003, p. 410); “Confrontar-se com o saber do sexual - traumaticamente, por estar esse assalto condenado de antemão ao fracasso, pela razão que enunciei: que o significante não é apropriado para dar corpo a uma fórmula que seja da relação sexual" (p. 411).

Voltando ao "seminário 20" gostaríamos por fim de destacar a formulação de Lacan em que expressa que o amor é uma solução 'não-toda'. Entendemos com essa expressão que o amor se presta ao sujeito como uma espécie de solução à inexistência da relação sexual, ou seja, que a aposta no amor pode amenizar os efeitos da lida com o real enquanto impossível, mas que essa solução inclui um furo, não é plena. Ao se investir no amor não se está livre da castração, sendo este caminho, portanto, parcialmente satisfatório. Na interpretação de Flanzer (2004), Lacan, neste seminário em que "edifica as dificuldades subsistentes no cerne da dinâmica amorosa entre o homem e uma mulher" (p. 129) transmite a ideia de que "entre um homem e a mulher, encontra-se o lodo, a sujeira, e o i-mundo, bem como a rachadura, a ruptura e o vazio. São presenças circunscritas da morte, bem como flagrantes vívidos do aspecto de divisão que a estrutura humana comporta. Nesta direção, o amor - aquilo que é capaz de os unir, homem e mulher - seria também o elemento mais revelador da imperativa impossibilidade de coesão que ali se insere" (Flanzer, 2004, p. 135). 
Diante do impasse, de um certo "vai não vai", Lacan se posiciona dizendo: "essa relação sexual, na medida em que a coisa não vai, ela vai assim mesmo" (Lacan, 1972-1973/1985, p. 46); "Não é do defrontamento com este impasse, com essa impossibilidade de onde se define um real, que é posto à prova o amor?” (p. 197). Terminará sugerindo que para aqueles que se lançam no campo do amor, trata-se de poesia e de coragem. A ideia de que o amor não é desaconselhável, apesar de sua complexidade, fica ainda mais explícita quando afirma que "é claro que entre os seres que sexuados são (embora o sexo só se inscreva pela não relação) existem encontros. Existe o feliz acaso [bon heur]" (Lacan, 1973/2003, p. $553)$.

Dessa visão sobre o amor enquanto artifício e como suplência deriva-se, pois, a crença de que entre os humanos há encontros possíveis. Encontros ao acaso e contingenciais, posto que, "uma vez que a relação sexual é impossível, se está submetido ao acaso do encontro amoroso" (Pfauwadel, 2014, p. 450). Ou, como propõem outros autores, "Lacan situa o amor como algo que vem a estabelecer um laço sobre o fundo da ausência da relação sexual" (Grinbaum, 2011, p. 35); "Para Lacan, neste momento, embora o sexo não se inscreva senão pela não relação está claro que entre os seres sexuados há encontros. (...) O amor não é mais do que encontro, puro acaso e, inclusive, cômico" (Rosa, 1998, p. 144); “A inexistência da relação sexual, inexistência que pode, então, tornar-se o lugar a partir do qual se torna possível uma criação particular" (Leguil, 2014, p. 445).

Pouco a pouco se evidencia que, segundo a psicanálise, quando abordamos os relacionamentos amorosos, convém enxergá-los como invenções, sempre singulares, mais da ordem da poesia, do humor e da coragem do que próximos a uma unidade perfeita. Como esclarece Dessal (2017), “o amor se afirma quando é capaz de renunciar à miragem da unidade com o outro" (Bauman; Dessal, 2017, p. 09). Por esse viés, entraremos agora na dissertação de Paz (2009), intitulada "Freud e o amor: do ideal ao impossível", leitura que nos serviu como fonte fecunda de conhecimentos a respeito do laço com o outro. A autora aborda o amor em Freud, discorrendo sobre o posicionamento do autor frente às suas tendências e à condição humana. O que mais nos interessou em seu trabalho foi a aproximação (existente na obra freudiana) entre o amor e a lógica pulsional, ao que Paz nomeou como "o impossível como afirmação". Segundo essa autora, 
mesmo nos momentos em que define o amor como os românticos, Freud não deixa de sublinhar os impasses que as próprias tendências românticas do amor carregam. Sendo assim, de diferentes formas Freud pôde articular a presença de um impossível no amor, ou seja, a imposição sempre presente de limites à felicidade na complementaridade amorosa. O destaque de Paz (e também o nosso) se dirige ao posicionamento ético freudiano que sustenta o impossível da felicidade na completude.

Em linhas gerais, a mensagem transmitida por Paz (2009) se centra no fato de que, para Freud, o desencontro amoroso não é uma contingência, ou seja, ele se fará presente necessariamente. Apresenta um enigma para falar disso, assim colocado: por um lado temos a afirmativa freudiana acompanhada pelo imaginário pós-moderno de que o amor ocuparia para o sujeito uma aposta na possibilidade de encontrar uma felicidade da plenitude. Por outro, sua afirmativa que indica que o projeto de felicidade do homem vai de encontro à sua inscrição na civilização e, por conseguinte, a presença de um impossível na experiência amorosa não é contingente, mas insuperável. Em seguida, formula algumas questões: "Que lugar ocuparia o amor - como aposta em uma felicidade da plenitude - na teoria freudiana que nos indica, em linhas gerais, que o projeto de felicidade - do qual se destaca o amor - no qual o homem se engaja com grande afinco, estaria fadado ao fracasso, posto não ser de felicidade ou plenitude que vive um homem, mas de um ritmo vacilante imposto pela pulsão?”; “Como Freud pôde nos ensinar sobre uma ética do impossível a partir de um ideal amoroso?"; "De que maneira Freud, que afirma pela construção da psicanálise um hiato à complementaridade entre sujeito e objeto representada pela proposição do conceito de pulsão, seria tocado pelo ideal romântico no que concerne ao amor?” (Paz, 2009, p. 17).

A autora destaca a "sustentação freudiana de um impossível necessário e não contingente colocado no centro do sujeito a partir da sua abordagem do conceito de pulsão" (p. 20). É a partir daí que Freud se distancia de uma leitura romântica do amor, isto é, pela introdução de outra visada dessa experiência, distinta da que tende ao absoluto. Ao introduzir o estatuto parcial do objeto, só é possível sustentar uma satisfação paradoxal no campo do amor. Conforme explica Paz, há um descompasso entre os amantes que "inclui um desapontamento sempre presente" (Paz, 2009, p. 56). Por meio desta aproximação entre o amor e a lógica da pulsão, fica destacado que Freud rompe radicalmente com o movimento 
romântico, posto que deduz uma visada do amor que não é regida pelos ideais de plenitude, idealização e exclusividade do objeto. Assim, complementa a autora, "sustenta no próprio encontro amoroso uma "topada" com uma experiência de impossível que convida o sujeito a responder de forma singular ao encontro com a atualização de seu ritmo vacilante no amor” (p. 21). Segundo a leitura de Lacan da obra de Freud, a novidade que este trouxe para o assunto pode ser assim explicada: "Qual foi a contribuição de Freud, sempre sozinho, para este tema? A ideia de um objeto harmônico, encerrado, por sua natureza, a relação sujeitoobjeto, é perfeitamente contradita pela experiência - não diria nem mesmo a experiência analítica, mas a experiência comum das relações entre o homem e a mulher. Se a harmonia nesse registro não fosse coisa problemática, não haveria análise em absoluto. (...) há, nesse registro, uma hiância, alguma coisa que não funciona (Lacan, 1956-57/1985 apud Paz, p. 45).

Vale frisar ainda, a partir da abordagem de Paz, a concepção de Freud enquanto um "pensador híbrido, cujo pensamento não se deixa aprisionar em uma única categoria" (Loureiro, 2002, p. 24, apud Paz, 2009, p. 47). Dessa maneira, aponta "tensões" (idem) que se estabelecem entre o amor romântico e o amor depreendido da pena de Freud. "Se por um lado Freud define o amor como aspiração pelo ilimitado, como aquilo que no sujeito não se contenta com menos que tudo - o que acompanha a definição romântica do amor - por outro lado sublinha, na contramão da visada romântica, estarem insuperavelmente imbricados amor e uma experiência de impasse, de ânsia insaciável, de impossibilidade de satisfação completa, o que nos encaminha para uma aproximação entre o campo do amor e uma lógica pulsional”. (...) “o posicionamento de Freud é, na contramão do romântico, a afirmação do caráter não efêmero, mas insuperável do impasse, de um desencontro, de um impossível da complementaridade amorosa" (Paz, 2009, p. 59).

Como exemplos dessas tensões próprias às postulações freudianas, Paz e Loureiro mencionam que ora Freud acompanha os românticos em sua definição do amor como apelo pelo absoluto, ora nos permite questionar a universalidade do amor romântico em sua aspiração pelo todo, quando evidencia sua outra faceta, não guiada por um ideal, mas pelo próprio desencontro amoroso. Isso se dá de forma explícita ao abordar o mal-estar advindo da relação entre os homens como algo não contingente e passível de superação, mas, ao contrário, que diz respeito à 
sua natureza e constituição psíquicas (como vimos anteriormente na análise do texto freudiano de 1930). Em momentos como este Freud é capaz de evidenciar que o ideal do amor romântico está irremediavelmente fadado ao fracasso. $\mathrm{Na}$ contramão da visada romântica do amor, identificamos aqui que o pensamento de Freud "não comporta a nostalgia de uma plenitude, nem o intuito de reencantamento do mundo", mas sim uma postura "cética e desilusionadora" (Loureiro, 2002, p. 27, op. cit., Paz, 2009, p. 92). A esse respeito, Flanzer (2004) acrescenta a sua contribuição, ao lembrarmos-nos da referência feita por Freud nos "Três ensaios sobre a teoria da sexualidade" (1905) ao mito de Aristófanes, no qual duas metades, separadas entre si, visam a unir-se novamente no amor. Ao invés de aderir a essa imagem, Freud realiza um desvio e uma transformação sobre a herança romântica na qual se banhara, uma vez que, em nenhum momento de sua obra ele aspira "à completude ou a algum tipo de transcendência" (Loureiro, 2002, p. 27 op.cit., Flanzer, 2004, p. 21).

Ao tomarmos a característica da pulsão de ser uma força que exige trabalho ininterruptamente, algo que nos acossa de modo constante, podemos compreender que a busca por satisfação é um movimento que não cessa. Isso se dá a nível individual, na lida de cada um consigo mesmo, e se estende também para a dimensão das relações, desde onde se pode inferir que há, "pela articulação entre amor e pulsão, um hiato insuperável entre o homem e a experiência de um amor feliz" (Paz, 2009, p. 47). Nas palavras da autora: "Ao afirmar que o que mobiliza o movimento amoroso não é mais apenas a crença romântica no Um, mas também a imposição de um impasse à satisfação amorosa, Freud, diferentemente do posicionamento romântico que afirma a contingência do impasse amoroso, afirma que o encontro com um impasse não é pontual e contingente, mas necessário à própria renovação do amor. Onde a definição romântica afirma uma imbricação entre amor e plenitude, Freud aqui afirma, pela aproximação entre amor e com - pulsão, uma imbricação entre amor e um desencontro, um impasse, um impossível” (p. 57).

Junto à Paz, recorremos novamente à Lacan na tentativa de compreender o paradoxo da satisfação no campo do amor. Acompanhando o ensino de Freud, o autor afirma que como resultante de uma força em constante exigência de trabalho, a satisfação da pulsão é paradoxal (Lacan, 1964/1985, p. 158), posto não haver satisfação encontrada capaz de pôr fim à exigência de trabalho. $\mathrm{O}$ paradoxo 
reside no fato de que em cada satisfação sobra um resto "a satisfazer", um resto que retorna como exigência de satisfação, de modo que satisfação e "o a satisfazer" se encontram em um só lugar. Como Freud, Lacan nos adverte para que não igualemos o fato da satisfação incluir o retorno desse resto a satisfazer a uma 'não satisfação' da pulsão. Dizer que há o retorno de um resto a satisfazer não equivale a uma negativa da satisfação. Citando Lacan, "não se pode portanto dizer que o alvo não é atingido quanto à satisfação. Ele é atingido" (idem). A questão é que, no que se satisfaz, a pulsão não deixa de retornar como exigência de satisfação; isso Freud nos indicara - vimos - desde que define seu estatuto de força em constante exigência de trabalho. Neste mesmo sentido, uma vez mais aproximando "a relação do amante com seu objeto sexual" ao movimento da força pulsional, Freud afirma que "por mais estranho que pareça, creio que devemos levar em consideração a possibilidade de que algo na natureza do próprio instinto sexual é desfavorável à realização da satisfação completa" (Freud, 1912c/1974, op. cit., Paz, 2009, p.171).

Uma última contribuição desta autora rica para nossa pesquisa é a alusão feita à psicanalista Loureiro, referente à ética freudiana. Segundo ela, pelo amor, Freud pôde sustentar sua ética, que guia a psicanálise por ele depreendida. Ética que, "caso fosse preciso nomeá-la, certamente lhe caberia o epíteto "ética da finitude', ou ainda, da renúncia às ilusões" (Loureiro, 2002, p. 345, op. cit. Paz, 2009, p. 123). O que nos interessou particularmente nessa formulação é a possibilidade de problematização daí decorrente. As dimensões da finitude e das 'não ilusões' nos impelem a pensar sobre o universo cibernético, com suas características específicas, de onde decorrem possibilidades inéditas e sedutoras, tais como: as infinitas janelas a que podemos acessar; a manutenção de "conversas" com pessoas mortas através de seus perfis mantidos "vivos" nas redes sociais; a garantia do anonimato em postagens; a criação de perfis falsos; o uso de filtros ultra-poderosos em fotos pessoais. Poder ter à mão esses recursos gerou a já vulgarizada visão acerca da internet segundo a qual ela é vista como convite ao infinito, à ilusão e à 'não castração'. Nossa proposta é debater essa visão predominante partindo da questão que agora formulamos: como navegar pelo infinito, regidos pela ética da finitude?

Antes de passarmos para o próximo capítulo, em que nos aprofundaremos nessa e nas demais questões que lançamos aqui a respeito da web, consideramos 
interessante dividir com o leitor a abordagem de alguns psicanalistas a respeito da experiência da solidão. Aqui, diferentemente do que apresentamos no início do capítulo (onde o foco foi a solidão enquanto estrutural), a intenção é apresentar formulações sobre a experiência de 'estar só', ou seja, de estar momentaneamente na ausência de uma companhia. Acreditamos ser um bom modo de nos aproximarmos das reflexões que nos interessam sobre a internet e sobre a forma com que esta se inseriu em nossas vidas. Convidamos então o leitor a ter em mente essa temática na leitura dos trechos a seguir.

Bassols (1994) destaca a multiplicidade intrínseca à(s) experiência(s) da solidão. "Temidas ou buscadas, angústia para uns, refúgio para outros há, enfim, diversas solidões, diversas maneiras de estar sozinho" (Bassols, 1994, p. 23). Audibert (2008) aborda a temática propondo uma divisão esquemática em que, de um lado existiria uma solidão mortífera e de outro, uma "boa solidão, uma solidão serena, absolutamente necessária ao nosso equilíbrio psíquico". Conforme a define a autora, "a solidão é uma questão humana essencial, em relação a qual somos todos confrontados ao longo de toda nossa vida, e, mais particularmente nos momentos em que estamos mais frágeis, como na velhice, na infância, na doença ou quando somos abandonados por alguém” (Audibert, 2008, p. 11) Discorre sobre como cada um lida com o "sentimento de ser / estar sozinho", apontando para a existência de distintas capacidades de se haver com esse fato. Em linhas gerais, propõe que possamos viver a "vida e seus momentos de alternância entre estar sozinho e estar com os outros, sem que isso seja um malestar" (Audibert, 2008, p. 12).

Dunker (2017) desenvolve uma série de ensaios a respeito da solidão, agrupando-os com o curioso título "solidão: modo de usar". Daquilo que desenvolve, destacamos algumas ideias que nos pareceram ricas para o que estamos trabalhando nessa tese. O que mais nos chamou a atenção foi a subversão feita pelo autor da ideia mais imediata, advinda do senso comum, de que solidão é um, é isolamento, é ausência de companhia. Esforça-se de diversas maneiras para demonstrar o quão importante é para cada um de nós tentar aceder à “possibilidade de ficar junto e separado" (Dunker, 2017, p. 09). Prega, como um dos "modos de usar" a solidão, que "a verdadeira e produtiva viagem solitária pode ser feita a dois, em grupo e até mesmo em meio à dissolução do indivíduo na massa, mas o pior mesmo é quando tentamos evitá-la” (p. 19). Seguindo em seu 
raciocínio, pontua: "A maior parte das pessoas pensa que o amor é uma experiência comunitária. Em grande medida, ele é uma experiência de solidão"; "a pior e a melhor forma de solidão é aquela que se vive a dois"; "A solidão benéfica nunca se estrutura em torno de Eu não preciso do outro. É justamente quando me dou conta de que preciso do outro, mas não absolutamente, que a solidão se torna um espaço criativo. Ou seja, nesse momento ela deixa de ser sentida como experiência deficitária"; "Solidão benéfica é solidão reconhecida. Cultivo da solidão é cultivo do Outro que nos habita" (p. 31). Por fim, traz uma distinção que nos parece fundamental, à qual recorreremos quando refletirmos, por exemplo, a respeito do uso que os adolescentes têm feito de seus smartphones. Referimo-nos à predileção de Dunker pelo termo separação, ao invés de isolamento: "Em vez de isolamento, prefiro a palavra separação. Ou seja, separar-se do Outro é um movimento, um tempo, que é absolutamente necessário para poder estar com o outro" (p. 34); "cuidamos de nós mesmos através dos outros" (p. 35).

Em ensaio destinado à solidão, Katz (1996) defende que "é preciso aprender a ser só", já que "nem sempre isolamento rima com sofrimento". Por conta dessa mensagem, seu livro é visto como "veemente defesa do direito de não comunicar, de não externar sentimentos e opiniões ou compartilhar momentos quando o mundo tagarela dos meios de comunicação exige justamente o contrário". Assim, Katz sustenta uma "solidão positiva", aquela em que "não se vive simplesmente como dor a ausência de alguma coisa ou de alguém, mas, ao contrário, faz desta falta um fator de fortalecimento"; "o humano precisa da solidão, cria modos de sua afirmação" (Katz, 1996, p. 41).

Enfim, caminhamos para o término deste capítulo ressaltando uma vez mais pressupostos fundamentais que pretendemos sustentar nessa tese: solidão e laço com o outro são temas em continuidade, não estão em oposição. Ambos fazem parte da vida e não nos parece frutífera a discussão de qual dos dois é melhor ou pior para um sujeito. Do mesmo modo, aderir a argumentos que acusam ou defendem a internet de ter nos deixado mais solitários ou mais conectados não nos parece o caminho mais interessante de se aproximar da discussão acerca do tema. Cremos que a essa altura já esteja claro que nos afinamos muito mais com a perspectiva segundo a qual tanto na solidão quanto no laço o prazer e a dor comparecem. 
A fim de ilustrar tal fato escolhemos um exemplo clínico apresentado por Audibert (2008). Ela nos conta sobre uma paciente que sofria por viver dividida entre o medo do outro e o pavor de ficar sozinha (Audibert, 2008, p. 18). Ampliando suas reflexões para além deste caso específico, que demarca bem esse estado delicado em que se fica "entre o medo e o pavor", prossegue a autora: "Se a solidão é para muitos um recurso precioso, ela pode ser também devastadora para alguns, quando a companhia dos homens não supera suficientemente a angústia da solidão ou quando a confrontação humana a desperta e a exacerba, através das separações, perdas, ausência, exílio, incomunicabilidade, incompreensão, traição, indiferença, infidelidade, frustrações, vulnerabilidade, ou toda forma de invasão, abuso, maus-tratos ou negligência por parte do outro" (idem, p. 16).

A lista é grande! E, sabemos que poderíamos acrescentar muitos outros elementos a ela, tamanhos são os possíveis desencontros nessa confrontação com o outro. Pois é daqui que partimos para o último capítulo da tese, em que nos dedicaremos à entrada da internet em nossas vidas, às suas incidências justamente nesse âmbito da confrontação humana consigo e com o outro. Nós e a rede, nós em nossa condição de finitude, ela com sua infinidade de possibilidades... Quais os desdobramentos dessa experiência? Investigaremos que novos elementos se somam a essa lista, assim como as nuances que a existência dessa complexa e viva rede trouxe para esse cenário dos relacionamentos humanos. 


\title{
CAPÍTULO 3
}

\section{A COMUNICAÇÃO DIGITAL ENTRE OS SERES FALANTES:}

\section{A TECNOLOGIA APLICADA À VIDA AMOROSA E SEXUAL}

\author{
Antes de existir computador, existia tevê (...) \\ Antes de existir a voz existia o silêncio \\ O silêncio. \\ Foi a primeira coisa que existiu ... \\ Arnaldo Antunes, $O$ silêncio
}

Começo com a frase escutada na clínica, marco inicial de onde nasceu a questão de pesquisa que agora se transforma em uma tese: "Minha casa parece uma lanhouse". A triste constatação deste pré-adolescente, dizendo que, para ele, em casa, só existia o computador e o silêncio, traz consigo a notícia incontestável de que o laço social está em mutação e que a internet tem a ver com isso. Transportando-nos dessa casa com cinco pessoas e múltiplas telas conectadas para o lar de uma criança atendida pela psicanalista Julieta Jerusalinsky, deparamo-nos com a seguinte cena: sua família, muito unida, como tantas outras, sempre fica junta na parte da noite depois do trabalho e da escola. O que fazem? Cada um olha para sua janela virtual individual. Tal relato pôde ser dito pela paciente de oito anos logo após ter feito um desenho em sessão, no qual ela, seus pais e seu irmãozinho flutuavam na tela do computador (Jerusalinsky, 2017b, p. 49). Extraímos das duas situações a mensagem de que "a casa torna-se um centro de lazer multiuso" (Bauman, 2004, p. 84), expressa de modo singular, porém semelhante, por cada um desses sujeitos.

Das casas para as ruas, a percepção de que a internet veio para ficar e trouxe com ela impactos significativos para a vida relacional das pessoas só aumenta. Se hoje (ano de 2019 em que escrevo este texto) esta afirmação soa absolutamente óbvia, há cinco anos, quando trabalhava em uma escola e não me encontrava envolvida em nenhuma pesquisa acadêmica, observar certos hábitos gerava espanto, perplexidade. Refiro-me especificamente ao que observava diariamente na hora do recreio, quando os adolescentes interagiam uns com os outros através de seus telefones celulares. Sentados lado a lado na mesa da cantina ou na arquibancada do pátio, batiam papo e davam risadas trocando mensagens 
por escrito, seja com amigos da própria escola, seja com aqueles que estudavam fora dali. Como entender a importante presença daquele novo objeto transformando a convivência no antigo espaço do recreio? O que a comunicação digital entre os seres falantes, definitivamente instalada, tem a nos dizer sobre os laços que estabelecemos uns com os outros? As indagações da presente pesquisa começavam, já ali, a surgir.

No campo do amor conjugal são múltiplas as imagens que refletem essa novidade, testemunhando as incidências da tecnologia na vida amorosa e sexual. Por ora elegemos duas: a charge-denúncia do polêmico artista de rua Banksy ${ }^{1}$ retrata um casal que se abraça calorosamente enquanto cada um olha para a tela de seu aparelho telefônico. O desenho ilustra situações atualmente comuns, como as vividas em jantares supostamente românticos, em que, além das clássicas velas acesas entre os parceiros, há a luminosidade proveniente das telas dos respectivos celulares. Sobre elas, alguns autores e cidadãos de nosso mundo comentam coisas do tipo: "cada um diante de sua microtela, como um par de autistas" (Goldenberg, 2017, p. 82). A outra situação que escolhemos para introduzir a discussão proposta para esse capítulo, visa, propositalmente, sublinhar o lado oposto da moeda. A impossibilidade de tirarmos uma conclusão única a respeito das cenas demonstra a complexidade do tema, complexidade esta que nos esforçamos por manter viva ao longo de toda a tese. Através de Anzalone (2014), tomamos conhecimento da interessante história de um casal de noivos do interior de Minas Gerais que se encontrou pela primeira vez no próprio casamento. Conheceram-se pela internet, namoraram um tempo através dela, decidindo não se conhecer pessoalmente até o momento do casamento.

Da cultura para a clínica, finalizamos essas linhas introdutórias compartilhando o depoimento escutado de uma jovem de dezesseis anos, no qual nos chamou a atenção justamente a mescla existente entre o encontro "ao vivo" e o encontro on-line. Ao contar à analista que pela primeira vez disse "eu te amo" para o recém-namorado, salienta que só conseguiu dizê-lo através de uma mensagem de texto, ao chegar de um passeio hiper romântico com ele. Nem para nós, nem para a própria jovem, ficou claro o papel da internet neste fato. "Não sei

\footnotetext{
${ }^{1}$ Disponível em: https://www.b9.com.br/51534/smartphone-ele-nos-ajuda-ou-nos-possui.
} 
por que" é o que pôde dizer, por enquanto, sobre o modo que saiu a declaração de amor.

Apresentamos assim o conteúdo deste capítulo, a parte da tese em que se concentram as reflexões referentes à solidão e ao laço com o outro na Era da Internet. Conforme assinalamos nos capítulos anteriores, adentraremos agora na discussão acerca da rede e de seus efeitos sobre a lida de cada um consigo mesmo e com o outro. A proposta em que nos empenhamos anteriormente, de traçar paralelos, de construir pontes entre as teorias de Freud e de Lacan e aquelas a respeito da cultura digital, segue vigorando. Reiteramos, portanto, o convite de que sigam exercitando o diálogo entre os capítulos, acompanhando-nos neste esforço que certamente foi o nosso.

\section{1) De onde partimos}

Começou com o sonho de um mundo conectado. Um lugar onde todos poderiam compartilhar experiências e se sentirem menos sozinhos. Não demorou muito para que este mundo se tornasse nosso cupido, verificador de fatos, animador pessoal, guardião de nossas recordações e até nosso terapeuta.

Karim Amer, Jehane Noujaim, Privacidade Hackeada

A presença das novas tecnologias em nossas vidas aumentou radicalmente nos últimos anos, impactando profundamente a tessitura dos laços sociais. É fato que hoje dispomos de novos meios para "circular eroticamente pela sociedade" (Goldenberg, 2017, p. 83) assim como o é a produção de efeitos subjetivos imprevisíveis a partir do advento da internet. Tendo em vista que o digital faz surgir um novo espaço social, desejamos investigar de que modo a tecnologia está afetando nossas relações com os outros. Considerando que o Brasil tem 230 milhões de smartphones em uso ${ }^{2}$, que 2.2 bilhões de pessoas no mundo estão inscritas no Facebook e que o Instagram possui 1 bilhão de usuários ativos, parece-nos extremamente válida essa reflexão sobre virtualidade e laço.

Buscando fugir de uma visada moralista a respeito do tema, já que a psicanálise não se destina a um juízo do homem nem da sociedade, focaremos nas

\footnotetext{
${ }^{2}$ Dados de abril de 2019 extraídos de pesquisa da FGV-SP. Fonte: Matéria na Revista Época.
} 
mudanças ocorridas no campo dos relacionamentos por conta da conexão em rede. Se "foi bom ou ruim", se "afasta ou aproxima", caberá a cada sujeito exprimir-se. O que nos move a pesquisar é localizar as novidades, explorá-las a partir do referencial teórico da psicanálise e tirar disso um duplo proveito: contribuir para o debate teórico na atualidade com aquilo que o saber psicanalítico é capaz de oferecer e manter vivo e atual o fazer psicanalítico.

Como pensar sobre essas dimensões da vida - a solidão e o laço com o outro - na interface com as possibilidades inéditas trazidas pelo advento tecnológico da internet? Inspirados na bela expressão criada por Sibilia (2015), subtítulo de um de seus livros, seguimos perguntando: o que temos percebido em relação à "alquimia dos corpos e das almas à luz das tecnologias digitais"? Interessa-nos investigar de que forma "fenômenos tipicamente contemporâneos como a "presença virtual", que "expande enormemente certas capacidades de estar e agir no mundo" (Sibilia, 2015, p. 60) modificam o que até aqui pudemos teorizar sobre solidão e laço. A questão que desejamos perseguir pode ser também assim formulada: quando "as redes globais de telecomunicações e suas diversas aparelhagens de conexão oferecem acesso às novíssimas "experiências virtuais" que hoje proliferam, dispensando tanto a organicidade do corpo presente quanto a materialidade do espaço e a linearidade do tempo" (idem, p. 61), solidão e laço se veem profundamente alterados? Dito de outro modo, a digitalização da vida chega a "turvar definições que outrora pareciam claras e inquestionáveis, como a de ser humano"? (ibidem, p. 69).

Postar e publicar textos e imagens pessoais na rede mundial de computadores pode ser uma forma de se relacionar, de se endereçar ao outro, de se haver com a própria solidão. Afirmar que vivemos em tempos de conectividade significa dizer que temos à disposição a conexão assombrosa e imediata a milhares de quilômetros de distância, a sensação de estarmos todos unificados e acessíveis de um jeito inédito. Significa ainda que a rede se tornou um direito fundamental para pessoas de todo tipo e que temos hoje a possibilidade de acesso ao alcance de um clique de praticamente qualquer lugar do planeta. Quando se está sozinho, atualmente, na grande maioria das vezes conta-se com a presença de um smartphone, o que altera esse estado. São tempos novos, portanto, onde a instauração da interatividade se dá em níveis sem precedentes, em que habitam sujeitos absolutamente plugados, época marcada pela fluidez, pela mobilidade. 
Nesse contexto, o que pensar, a partir do referencial teórico da psicanálise, a respeito dos relacionamentos perpassados pela mediação digital? Nadia Laguardia de Lima, psicanalista e autora de referência nesse campo de estudos no Brasil, diretora do grupo de pesquisa "Além da tela", observa a existência de novas formas de pertencimento social, de identificação e de invenção. Pontua que "as tecnologias digitais alcançaram uma potência inusitada, incidindo sobre a organização social de forma incomum na história da humanidade" (Lima, 2017, p. 07). A partir dessas constatações indaga: "como as condições de socialização são afetadas pelas redes sociais?” (idem, p. 08).

Antes de passarmos para as seções em que nos deteremos nos sub-temas que elegemos nos aprofundar, gostaríamos de esclarecer como chegamos a eles. À medida que íamos pesquisando, fomos percebendo que os autores que se interessaram pelo tema da internet e suas reverberações sobre as subjetividades, de forma geral discorriam sobre certos aspectos que lhes chamavam mais atenção. Nas leituras, percebíamos pontos que se repetiam, levando à conclusão de que eram pontos fundamentais a serem estudados. Conforme a pesquisa avançava, notamos também que um mesmo ponto podia apresentar pontos de vistas opostos. A polêmica estava evidente. Diante do que fomos encontrando na revisão da literatura, construímos as seções a seguir, compostas por ideias trabalhadas por certos autores e pela costura de nossa autoria entre eles. Colocando-os para dialogar através de nosso texto, e, na medida do possível incluindo comentários oriundos de nossas próprias reflexões enquanto pesquisadoras do tema e psicanalistas - intencionamos sempre desenvolver nossa análise crítica a respeito do que trazem, na tentativa de avançar com a discussão. Visamos com isso contribuir para que aquele que tenha acesso a esse material possa, ele mesmo, alimentar suas reflexões, elaborar suas próprias questões.

Uma vez mais, vale lembrar que nesse momento, dada a atualidade e a complexidade do tema, as perguntas nos pareceram mais ricas, fecundas e potentes do que as respostas ou posicionamentos mais conclusivos. Apresentaremos, portanto, hipóteses em aberto, construções teóricas possíveis, tomando nosso trabalho como "precário por definição, na medida em que se refere a um real em permanente ebulição" (Lyra, 2019c, p. 03). Como inspiração e uma espécie de imã, guiamo-nos pela pontuação de Lima (2017), que destaca "uma posição de estranhamento de certos autores em relação ao tempo contemporâneo, 
o que permite interrogá-lo continuamente" (Lima, 2017, p. 12). Com essa “postura-imã" em mãos, fomos sendo atraídos justamente pelos autores que conseguiam ao mesmo tempo escrever algo e manter o ar de estranhamento a respeito da internet, sem matar as perguntas, sem se fechar em posturas engessadas e mortificadas.

\section{2) "Novas solidões" da Era da internet}

As pessoas estão se distraindo, pois a desgraça da humanidade é que nós não podemos mais nos refugiar em um quarto sem estar conectados.

Éric Laurent, Jouir de l'internet

Para refletirmos sobre a interface entre a rede e a solidão partimos do princípio, já exposto no capítulo anterior, de que a solidão é um dado de estrutura entre os humanos. Enquanto algo ineliminável, "essa verdadeira solidão - a estrutural" (Álvarez, 2015) seguirá existindo independente das reviravoltas produzidas pela ciência ou de qualquer outra criação que a humanidade venha a fazer. A seu respeito, nos esclarece Álvarez: “a inexistência da relação sexual é um dos nomes da verdadeira solidão, daquilo que situa o desamparo do ser falante" (Álvarez, 2015). Esta dimensão da solidão difere, entretanto, de uma solidão fenomenológica, mais próxima ao afeto de sentir-se só de que nos fala o senso comum. É neste âmbito que podemos observar nuances que marcam os tempos atuais como distintos do passado. Dito isso, podemos partir para a discussão a respeito da solidão em nossos dias, naquilo que ela tem de específico, no modo como se apresenta distintamente do que fora outrora.

Iniciaremos esse exercício causados pelo seguinte paradoxo: em uma época na qual estamos submetidos à comunicação digital perpétua observamos uma crescente solidão existencial (Bauman; Dessal, 2017, p. 03). Uma das inquietações advindas dessa colocação remete ao papel que a internet tem nesse crescimento da solidão existencial, no aumento da sensação de vazio entre as pessoas. Quanto a isso, nossa postura é clara: não nos posicionaremos de um lado ou de outro diante dessa "versão 2.0" do clássico dilema "o que vem primeiro, o ovo ou a galinha?". Se foram as redes virtuais que produziram tal fenômeno ou se já estávamos assim e por isso nos agarramos fervorosamente a elas, não sabemos 
dizer. Interessa-nos analisar as novidades que surgiram junto à web nos modos singulares de o sujeito habitar a solidão. Que novas possibilidades a navegação on-line oferece e quais os efeitos disso nesse âmbito de nossas vidas? No cenário atual, quais as novas formas subjetivas de tratar a solidão? A seguir, mergulharemos nas proposições de autores contemporâneos a esse respeito.

Primeiramente gostaríamos de destacar nossa surpresa diante das inúmeras nomeações novas que a solidão ganhou nos últimos anos, todas aludindo à internet. Da Escola de Orientação Lacaniana argentina eis o termo "solidões contemporâneas enlaçadas na web", título escolhido para as XXV ${ }^{\mathrm{a}}$ Jornada da EOL que ocorreu em 2015. Nota-se aqui uma mescla interessante entre solidão e laço, da qual se infere que os solitários se enlaçam ao utilizarem a rede, que se encontram "não tão sozinhos na rede" (Álvarez, 2015). Defensor de uma visão oposta a respeito dos efeitos das redes virtuais no par solidão / companhia, o jovem ativista e estudioso da internet Pariser (autor de $O$ filtro invisível) considera que "profundamente conectados, vivemos isolados". Denomina essa nova forma de solidão de "iSolamento", brincando com a grafia dos nomes de produtos da marca Apple (Karnal, 2018, p. 48). O sociólogo da comunicação parisiense Dominique Walton, por sua vez, apresenta-nos o termo "solidão interativa" para falar da solidão das redes. Segundo ele "podemos passar horas, dias na internet e sermos incapazes de ter uma verdadeira relação humana com quem quer que seja" (Karnal, 2018, p. 53). "Verdadeira" aqui deve ser entendida no sentido de contraditória, daquela que inclui a necessária negociação com o diverso de nós mesmos. É como se a interação nas redes nos fizesse esquecer daquilo de que falara Freud e nos relembra Karnal: “a companhia é um alívio e também uma dificuldade" (p. 54).

Lyra (2019c) nos apresenta a "solidão hiperconectada" sobre a qual arrisca a hipótese de que a prevalência das novas tecnologias nos laços sociais produz um fenômeno cuja marca não é o rompimento dos laços, mas sim o esvaziamento de cada uma das múltiplas interações feitas a todo instante. Segundo o psicanalista, “o paradoxo da expressão solidão hiperconectada revelaria não tanto a delicadeza de fazer da singularidade o fundamento do laço, mas o seu oposto, a enorme dificuldade que certos traços contemporâneos impõem a esse movimento" (Lyra, 2019c, p. 03). Para ele, a marca da solidão hiperconectada não seria tanto o isolamento radical, mas a dificuldade de endereçar e acolher tramas de textos 
complexos (idem, p. 05). No nosso entender, parece caracterizar as conversas no mundo virtual como superficiais e pouco íntimas, conversas nas quais colocamos pouco de nós mesmos. Em suas palavras: "Cada um pode participar, por exemplo, de incontáveis grupos, compondo um mosaico de interesses diversos, mas não poderá, certamente, em cada um desses grupos, "mudar o rumo da prosa", ou seja, articular os seus S2. É um ambiente hostil à associação livre, nossa regra de base para o encontro com o gozo singular" (idem, p. 04).

Complementando a lista dessas que agrupamos como "as novas solidões da Era da internet" temos a "solidão acompanhada" apresentada por Anzalone (2014) e também por Álvarez (2015). O primeiro autor parte da proposta de Zuckerberg (criador do Facebook) de criar um mundo "mais aberto e conectado" para então afirmar que as redes sociais "se tornam ao mesmo tempo sintoma e solução para a solidão dos sujeitos". A solidão acompanhada seria aquela que ao mesmo tempo inclui o estabelecimento de algum vínculo e a manutenção da solidão. "O sujeito contemporâneo parece gozar justamente dessa solidão acompanhada preso em suas armadilhas de gozo", nos diz Anzalone (2014). O elemento crucial que diferencia essa solidão acompanhada de uma, digamos, "antiga" solidão é o smartphone. Segundo o psicanalista, estabelecemos com estes aparelhos uma nova forma de parceria sintomática, em que os sujeitos parecem nunca estar sozinhos, já que tais gadgets nos acompanham a todas as partes, "desde a fila do supermercado até a solidão do vaso sanitário" (p. 290). Anzalone conta inclusive uma situação pessoal anedótica: certa vez, ao perder seu telefone, deparou-se com a "queda dessa ilusão de companhia".

O programa jornalístico de humor Greg News, criado e protagonizado por Gregório Duvivier, dedicou um de seus episódios aos celulares, visando transmitir a mensagem de que estes aparelhos só disfarçam a solidão. Em "Celular" (junho de 2018) Duvivier lança ao público provocações como "Afinal, quem acha que está sozinho com 3254 amigos no Facebook, 726 seguidores no Instagram e uma reunião de condomínio infinita no Whatsapp?" ou "Precisa acabar a bateria do seu celular para você perceber que todo mundo a sua volta está no celular" na tentativa de nos convidar para esta reflexão. Apresenta, ainda, dados interessantes e impressionantes que falam da presença maciça dessas maquininhas em nossas vidas, e, paralelamente, da interferência que têm na nossa lida com a solidão e com nossos companheiros. Americanos checam o celular cerca de quarenta e sete 
vezes por dia. Entre 18 e 24 anos a média é de oitenta e duas vezes. $7 \%$ dos adultos admite checar o celular durante o sexo.

Álvarez (2015), por sua vez, teorizará a respeito dessa "nova" solidão a partir de um paradoxo. Diz ela: "é uma rede de computadores e de pessoas, mas que pode, ao mesmo tempo, acentuar o isolamento das pessoas ou suas sensações de solidão. Mas, quando o sujeito está jogando sua partida com seu ideal ou com a pulsão, seria uma "solidão entre aspas", uma solidão muito cheia, sem vazio, uma solidão muito acompanhada" (Álvarez, 2015).

Em contato com essas teorizações, desejamos destacar o debate acerca da lida com a alteridade no mundo contemporâneo, que entendemos estar presente nas entrelinhas de diversos autores a que nos referimos. Interessa-nos particularmente pensar sobre a presença da alteridade nas trocas via internet, ou seja, se exercitamos ou não nossa capacidade de lidar com o outro, com o diferente, com a alteridade, portanto, nas conversas que travamos on-line.

Em sua tentativa de elucidar ao jornal Le point de que forma Lacan pode nos ajudar a compreender a época atual, Miller (2011) foca diretamente nesse ponto. Calcado na crença de que podemos decifrar nosso presente utilizando a gramática de Lacan, enxerga a humanidade segundo a ótica de que "cada um está entregue à solidão do "Um"”. Entendendo o "Um" como o culto da identidade do eu consigo mesmo, deduz-se a dificuldade de suportar o outro, aquele que não goza da mesma maneira que você. Para esmiuçar essa noção lacaniana do "Um" Miller refere-se à sexualidade, ao fato de que cada um goza a seu modo, cada um tem seu modo de gozar. Sendo assim, o gozo de um não é complementar àquele de seu parceiro, isto é, "na base, no inconsciente, seu gozo não é complementar ao de ninguém".

Entendemos tal formulação de Miller (2011) como mais uma forma de descrever a solidão estrutural, o desamparo constituinte. Porém, o que parece apontar como novidade nos tempos atuais é o quanto isso está exposto, o quanto essa solidão do "Um" tem sido experimentada de forma explícita pelo sujeito contemporâneo. Se outrora, nos diz Miller, as construções imaginárias sustentavam uma fusão entre um e outro, na crença romântica de um amor complementar (na tradição do casamento, por exemplo) hoje isso vacila. O que se tornou um valor maior é o direito de cada um a gozar do seu modo. "O direito de cada um ao seu próprio gozo tornou-se um direito humano". Logo em seguida a 
esta contundente afirmação, Miller inclui observações sobre a internet em sua resposta aos jornalistas, caracterizando-a como uma das adições possíveis nesse cenário de enaltecimento do gozo de cada um. "O modelo geral da vida cotidiana no século 21 é a adição. O "Um" goza sozinho com sua droga, e qualquer atividade pode tornar-se uma droga: o esporte, o sexo, o trabalho, o smartphone, o Facebook...” (Miller, 2011).

Numa época em que a humanidade valoriza como direito máximo o gozo de cada um, parece haver um prejuízo na ideia de que a coletividade é um bem a ser zelado. Vivermos civilizadamente no convívio com o outro é fruto de trabalho, de esforço, disso já sabemos desde Freud (aspecto esmiuçado no capítulo anterior, mais especificamente no tópico 2.6). No momento em que a interação com a alteridade deixa de ser um valor a ser perseguido e transmitido, o curso natural das coisas parece rumar em prol de nossas individualidades, deixando o outro de lado. Que a internet se articula a esse movimento de forma notável é um dado trazido tanto nesta entrevista de Miller (2011) quanto no desenvolvimento do pensamento dos autores contemporâneos que têm se debruçado sobre o tema. A complexidade dessa articulação, que é o foco desta tese, tem aqui mais um ponto quente. Vejamos.

Ao afirmarmos que o outro é deixado de lado, que este perde importância em nome da valorização de cada indivíduo, como entender o exibicionismo, a importância dos likes e dos seguidores que compõem o cenário descrito por Sibilia (2016) como o Show do eu? Seria possível um show sem plateia? Talvez a questão mais interessante a respeito desse ponto seria nos perguntarmos "de que outros" é composta essa plateia virtual. Outros para quem a gente importa? Outros com os quais nos importamos? Ou apenas números? A problematização sobre quantidade ou qualidade pode ser útil nessa discussão, em direção a qual avançaremos junto a Sibilia e sua análise acerca da sociedade do espetáculo em que vivemos, na qual cada um estiliza a própria vida como se fosse o protagonista de um filme.

Visando ganhar existência, consistência e a legitimação do olhar alheio recorremos a uma infinidade de ferramentas ficcionalizantes disponíveis no mercado, sendo a internet um campo hiper fecundo para este fim, lugar privilegiado para a encenação desse show do eu (título de um dos livros da autora). A diferença entre esse personagem e uma pessoa real reside justamente - 
e isso muito nos interessa - na solidão e na capacidade de estar só: "os personagens jamais estão sozinhos. Sempre há alguém para observar o que eles fazem, para acompanhar com avidez todos os seus atos, seus pensamentos, sentimentos e emoções. Há sempre um leitor, uma câmera, um olhar sobre a personagem que lhe tira o caráter humano" (Sibilia, 2016, p. 338). Dando continuidade a sua reflexão, pontua aspectos bastante semelhantes àqueles provenientes do campo psicanalítico, facilitando o diálogo conosco. Por conta da solidão de nossas misérias cotidianas, de nosso isolamento íntimo e privado, que por vezes nos apavoram e geram temores, nos vimos incitados a nos disfarçar de personagens visualmente atraentes. Nas palavras da autora: "Essa repentina busca de visibilidade, portanto, essa ambição de fazer do próprio eu um espetáculo capaz de atrair a atenção dos outros, pode ser também uma tentativa mais ou menos desesperada de satisfazer um velho desejo humano: afugentar os fantasmas da solidão" (idem, p. 342).

No capítulo anterior indagamos se poderíamos pensar a internet como um recurso a mais na luta frente à solidão, novidade que veio se somar a outros recursos anteriormente existentes. Desejávamos pensar se o uso da comunicação digital poderia ser interpretado como um dos caminhos possíveis para administrar a solidão singular. O que Sibilia parece, porém, querer destacar é que assim buscamos afugentar esse fantasma, sem encará-lo verdadeiramente. Turkle (2017) caminha na mesma direção, ao afirmar que "as pessoas estão solitárias. A rede é sedutora. Mas se estivermos sempre conectados, negaremos a nós mesmos as recompensas da solidão" (Turkle, 2017, p. 03).

Turkle visa nos alertar de que o uso intensivo da internet atrapalha o exercício que cada um precisa fazer na lida consigo mesmo e, sendo assim, a rede não seria um recurso a mais e sim um "recurso a menos", ou melhor, um desserviço, algo que, nesse sentido, veio para atrapalhar. $\mathrm{Na}$ visão da autora, sempre distraídos, perdemos a capacidade de estar sozinhos, nos tornamos acostumados à estimulação social constante que apenas a conectividade pode proporcionar (Turkle, 2017a, p. xxi). Conforme observa, a internet faz quatro promessas, mas estas, como os desejos endereçados ao gênio da lâmpada, implicam em problemas, explicitam as vulnerabilidades de nossa vida digital. Eis as promessas, formuladas por Turkle (2017b): 1- "Você será sempre ouvido"; 2"Você não se entediará jamais. Haverá sempre alguma coisa para te distrair e te 
divertir"; 3- "Você nunca mais terá que ficar sozinho"; 4- "Você pode ser quem você quiser" (Turkle, 2017b, p. 133). Se nisso não houvesse furo, se o real não emergisse no virtual (aspecto em que nos aprofundaremos na seção 3.5 a seguir), a internet teria livrado o homem daquilo que o limita mais radicalmente, ou seja, a ciência teria chegado à eliminação da castração que marca fundamentalmente o ser falante.

A fim de seguirmos nessa discussão sobre o papel do uso da internet na lida com a solidão é hora de nos dedicarmos às ideias desenvolvidas por Audibert (2008). É preciso sempre lembrar que não estamos em busca de uma asserção conclusiva do tipo "ajuda" ou "atrapalha", assim como ter em mente que para cada sujeito, com sua história única, haverá um papel singular que a internet poderá ocupar. A psicanalista francesa contribui com esta perspectiva, ao localizar que, para algumas pessoas, ao procurarem tentativas para lidar com a solidão, o que seria um "remédio" torna-se um "veneno" 3 , porque se entra num espiral aditivo. Pessoas que têm mais dificuldade de estar sozinhas estariam se tornando usuários adictos à internet, fazendo uso compulsivo da rede como forma de tentar minorar os efeitos desprazerosos da solidão por elas sentida. Em entrevista concedida à revista Psychologies em 2013 Audibert afirma que por vivermos em um mundo conectado, nossa cultura e os ideais de sociabilidade que ela veicula desvalorizam os momentos consigo mesmo. Sob seu ponto de vista, justamente por vivermos em uma época repleta de novas ferramentas que permitem estarmos ligados com o outro, há um reforço da consciência da solidão, pois ao condenarem-na, a colocam em evidência. Algumas pessoas atribuem seu próprio valor ao número de curtidas e seguidores que possuem, dependendo disso para se sentirem seguras e amadas. Ser sozinho significa uma forma de perigo para a pessoa vulnerável que somos e, isso parece incomodar mais quando se tem a impressão de que todos ao redor estão vivendo a vida de forma alegremente compartilhada.

Relançamos então o paradoxo proposto por Dessal (2017), apresentado no início dessa seção, em que figuram lado a lado a comunicação digital perpétua e uma crescente solidão existencial. A ideia é propor um diálogo com certos aspectos do pensamento de Audibert, como os que dão corpo à citação a seguir:

\footnotetext{
3 Novamente aqui a alusão ao phármakon trabalhado por Platão e discutido por nós no primeiro
} capítulo da tese. 
"nossa civilização reflete a imagem da desolação que vive o homem solitário em meio à profusão e à densidade das grandes cidades, de onde a solidão serena foi abolida, como se toda solidão devesse ser banida, o que, por inversão, engendra um efeito inverso. De fato, a incapacidade de estar só parece mais exacerbada hoje em dia, nesse mundo em que dispomos de uma infinidade de estratégias de comunicação, cada vez mais sofisticadas" (Audibert, 2008, p. 20). Dando continuidade ao que propõe, a psicanalista salienta o quanto recorrer a esses meios digitais cumpre, às vezes, uma função inesperada, sempre sublinhando que o encontrado pode ser o inverso do que se procurava. Sobre esse ponto, levanta questões interessantes, embora a nosso ver, perigosas, por beirarem a polarização e o juízo moral. Ainda assim, vale transcrevê-las, para estimular nosso debate: "ao invés de permitir aos homens se sentirem menos isolados, será que não exprimem ainda mais sua inexorável solidão? O que pode ser pior para um adolescente do que um celular que não toca ou uma caixa de mensagens vazia? Estamos nos sentindo melhor e mais incluídos? Essa comunicação, tal como é apreendida por essas técnicas que aceleram o tempo, trouxeram melhorias para a qualidade das trocas, aumentaram o sentimento de ser escutado e compreendido?" (idem). Se fôssemos responder a estas questões com aquilo que aprendemos de nossa leitura de Turkle (2017) diríamos que as trocas, a escuta e a compreensão mútua estão em baixa. Isso porque a autora elege como o estado afetivo mais característico da cultura digital "um misto de solidão e de medo da intimidade". No quadro que descreve coexistem a conexão permanente, a vergonha por nos sentirmos sozinhos (já que, afinal, estamos cercados de "amigos"), além da culpa a respeito desse sentimento. Completando a cena, Turkle alude a um ciclo vicioso, pois os internautas acham mais fácil procurar reconforto nas relações virtuais (Turkle, 2017, p. 133).

Compreendemos a partir de Turkle, Audibert e Sibilia que as três autoras lamentam pelas perdas que estamos vivendo no âmbito da "boa solidão" ou da "verdadeira viagem solitária", sobre as quais dissertamos no segundo capítulo da tese. Nesse sentido, cabe acrescentar o comentário de Sibilia (2016) valorizando o tédio, na passagem de sua obra em que reflete sobre o quanto a hiperconexão roubou o tempo de "estar à toa". Para ela, "esse súbito impulso de ter que falar - e se mostrar - agora, já, em tempo real e do jeito que for, acabou atropelando aquele 
trabalho silencioso e solitário que outrora era considerado fundamental, tanto para pensar, quanto para escrever e se autoconstruir" (Sibilia, 2016, p. 308).

Dando prosseguimento ao debate sobre a "boa solidão" e à reflexão em torno da intimidade hoje - mencionada por Turkle (2017) através do "medo da intimidade" - chegamos a Christian Dunker, um dos autores de referência em nossos estudos. Assim como Turkle, ele parte da constatação de que na atualidade estamos menos íntimos uns dos outros. Para falar sobre isso, aponta para a existência de "uma nova forma de sofrimento psíquico" que acompanha as pessoas que "se declaram incapazes de formar um laço de intimidade com o outro" (Dunker, 2017b, p. 77). Temos então uma nova figura do sofrimento na contemporaneidade, o "déficit de intimidade" (idem, p. 80). O cenário descrito pelo psicanalista é composto por personagens que experimentam "uma estranha sensação de que estão a olhar o mundo como se estivessem fora dele", os quais "raramente estão de fato com o outro numa relação íntima" (p. 77). Mais uma vez é pertinente remeter ao paradoxo "comunicação digital permanente - agudização da solidão existencial”, sendo este ilustrado agora pelo "desagradável sentimento de solidão a dois e a insistente sensação de vazio" (idem). Dunker parece concordar com Dessal e com Audibert nesse ponto, já que considera esta "solidão a dois" mais terrível do que aquela que se vivencia ao andar no meio de uma multidão, "pois testemunha o desenraizamento de quem a experimenta" (p. 81).

Em nossa costura entre o pensamento dos diversos autores, assinalamos ainda a notável aproximação entre alguns aspectos apontados por Dunker (2017) e aqueles trabalhados por Turkle (2017). Ao abordar problemas atuais na "vida relacional das pessoas" (expressão interessante proposta por Dunker) toca em questões semelhantes às levantadas pela psicóloga americana quando elenca as quatro promessas da internet. Em tom igualmente crítico, Dunker situa fenômenos como uma "tendência à hipersocialização", a "disposição a ficar permanentemente ligado, ocupado ou disponível", a "impotência para constituir situações e percursos de real solidão ou intimidade" (Dunker, 2017, p. 13). Sobre este último ponto, o da construção da intimidade, vale a referência a Freud e ao paralelo que traça entre o laço com o outro e a convivência entre os porcos espinhos (ponto trabalhado anteriormente, na seção 2.6): "nenhum deles aguenta uma aproximação muito íntima do outro" (Freud, 1921). Daí se deduz que alcançar a intimidade com outra pessoa, no mínimo, não é algo simples. 
No ensaio "Solidão: modo de usar", já mencionado mais acima, cujo título brinca com a possibilidade de se ofertar uma espécie de manual da boa solidão, Dunker (2017b) aponta para a urgência de se tentar experimentar uma "solidão de verdade" (p. 33). Com o mesmo tom divertido do título, propõe o seguinte teste prático: "Toda vez que não há nada te ocupando, você pega um cigarro, pensa numa garrafa ou tenta abrir o Facebook? Toda vez que começam as férias ou chega domingo à noite, ou os filhos saem de casa, você sente um vazio composto de dolorosa tristeza? Está na hora de tentar urgentemente uma solidão de verdade" (p. 33). A partir da brincadeira proposta pelo autor podemos concluir que recorrer ao Facebook seria uma forma de se afastar da solidão de verdade, sendo a rede social a um só tempo uma forma de escapar do nada ("não há nada te ocupando") e de se manter no vazio e na tristeza.

Melgaço (2017) se lança na mesma discussão e depara-se com o mesmo paradoxo, ao pensar nas relações entre a hiperconexão e o desamparo. Pergunta-se se a tecnologia efetivamente funcionaria como "um anteparo contra a solidão" (Melgaço, 2017, p. 71), por conta do "mundo fascinante de onde provém a ilusão de que não estaríamos sozinhos" (idem). Lado a lado a esse fascínio e a essa ilusão, a autora situa, entretanto, outra conclusão: “a conexão exagerada com os aparatos tecnológicos pode, de certo modo, reforçar a sensação de desamparo quando partimos para o contato "face a face" com as pessoas" (p. 73). Fala de certo despreparo para o convívio em tempo real, que requer prática, que exige treino, e então enuncia, a seu modo, o paradoxo: "sentimos que a tecnologia nos ajuda a lidar com a solidão, mas, ao mesmo tempo, percebemo-nos cada vez mais sozinhos, especialmente quando estamos perto de outras pessoas" (idem).

Tomando como uma ponte oriunda das colocações de Melgaço a ideia de que podemos estar nos tornando mais ensimesmados e menos propensos a incluir os outros em nossas vidas, consideramos interessante apresentar a notícia "Selfies: vivendo na era das fotografias com filtro", que reporta um fenômeno atual extremamente curioso. Publicado na revista de cirurgia plástica JAMA o artigo ${ }^{4}$ apresenta o relato de cirurgiões plásticos que estão recebendo grande número de pacientes que desejam ficar iguais a si mesmos - mas a si mesmos depois de usados os filtros do Snapchat e do Instagram. Se antigamente se chegava ao

\footnotetext{
${ }^{4}$ Selfies - Living in the Era of Filtered Photographs. Disponível em: https//jamanetwork.com/journals/jamafacialplasticsurgery/article-abstract/2688763.
} 
cirurgião plástico com a foto de alguma beldade, de algum ídolo, hoje se chega com fotos melhoradas de si mesmo. Dias depois, o jornal "El País" traz reportagem de conteúdo semelhante, apontando para o mesmo fenômeno, cuja manchete é a seguinte: "Doutor, quero me parecer com minha selfie". O coro entoado por esses pacientes seria algo como: “Queremos nos transformar numa versão filtrada de nós mesmos". Talvez possamos entender esse novo comportamento como um exemplo extremo em que o outro não entra como um modelo, como um referencial, em que o 'eu sozinho' (porém melhorado) se bastaria.

As reflexões de um último autor nos interessam nesse debate acerca dos impactos da internet na forma com que experienciamos a solidão. Em seu mais recente livro, "O dilema do porco espinho" (2018) Karnal dedica-se diretamente à temática solidão / companhia, apontando para as redes sociais e para os smartphones como elementos fundamentais a serem considerados no século XXI. Acredita que as redes sociais provocam uma "ambiguidade notável" (Karnal, 2018, p. 24), quase levando-nos a crer que a resposta ao dilema de Shopenhauer tenha surgido junto a elas. "Qual seria o ponto que contenha calor suficiente e afastamento necessário dos espinhos dolorosos? Provavelmente, a resposta atual se chama mundo virtual" (p. 25), provoca o filósofo. Rascunha uma hipótese, em que o mundo digital figuraria como certa resposta encontrada pelas pessoas para equilibrá-las entre a dor da solidão e a dor do contato com outras pessoas, sendo "o acesso às redes a solução aos dilemas humanos" (p. 34). É importante deixar claro que essa hipótese de Karnal é intensamente debatida por ele mesmo em suas elucubrações, ou seja, não é uma conclusão fechada, que ele defenda com unhas e dentes. Suas hesitações permanecem ao longo do livro, como, por exemplo, em passagens como essas: "Aí está um admirável mundo novo que poderia eliminar toda solidão" (...) "Será?" (p. 40); “eis um bom desafio para o qual não tenho resposta clara, apenas intuições" (p. 55).

Extraímos deste livro uma formulação referente à internet que nos pareceu muito potente para a reflexão acerca das incidências desta rede nos relacionamentos humanos. Trata-se da ideia de Karnal de pensar a internet como "exercício de relação" (p. 56). Consideramos interessante que fale em exercício, pois de fato vemos que também no mundo virtual relacionar-se com o outro exige trabalho, tal como observara Freud a respeito dos relacionamentos travados antes 
da existência da internet. Destacamos ainda os paradoxos apresentados pelo filósofo em suas análises sobre a rede. Segundo ele, ainda que estejamos livres para bloquear, livres para fantasiar e livres para insultar, a comunicação virtual não nos libertou da solidão ou dos riscos dos espinhos. Ainda que haja magia, poder, ilusão de primeira qualidade e muita droga feliz, não estamos cobertos de felicidade. Entre sorrisos virtuais vivemos uma perigosa epidemia de suicídio entre jovens (Karnal, 2018, p. 41). Questionando os efeitos deste advento tecnológico no par solidão-laço Karnal indaga: “A internet, criada para integrar as pessoas, eliminar distâncias e barreiras, diversificar as perspectivas individuais, estaria criando uma espécie de "autismo digital”, "isolamento nas redes", "solidão entre milhões" e seres depressivos diante de uma infinita barra de rolagem?" (idem).

A partir de uma situação específica de uma professora habitante de uma pequenina e distante aldeia (caso semelhante ao do velhinho chileno de 95 anos apresentado no primeiro capítulo da tese), enuncia um paradoxo que para ele é o $\mathrm{X}$ da questão, algo que o intriga há tempos: como é possível deixar um isolamento sem sair de casa? Em meio à rede, vencemos a solidão ou ficamos mais sozinhos? (p. 42). O que dizer a esse respeito a partir do que a humanidade vivenciou diante da pandemia do novo coronavírus em que nos vimos impelidos a ficar em casa, utilizando a internet como forma prioritária de estarmos juntos, na medida do possível? A experiência da quarentena tornou evidente que com a internet tornouse possível (e até comum) isolar-se e ao mesmo tempo romper um isolamento.

Apesar de não pretender expressar-se em um tom conclusivo neste livro, Karnal traz uma posição bem clara especificamente a respeito das redes sociais. Mesmo não aderindo completamente a ela, consideramos rico acrescentarmos os argumentos do autor, pois enriquecem a discussão a respeito do tema. "Aqui lanço minha ideia, querida leitora ou estimado leitor: as redes sociais não oferecem o isolamento necessário para o crescimento nem a intimidade densa e até conflituosa da relação humana. Não ganho a paz nem enfrento a diferença" (Karnal, 2018, p. 55). "Não sendo favorável à paz interior em função de sua dinâmica interna (fluxo incessante, barra de rolagem infinita, movimento perpétuo), a internet, mesmo navegada de forma solitária, tem pouco potencial de iluminação e muita força de passatempo amortecedor do tédio" (p. 56). Karnal acredita, portanto, que as redes sociais deixam a desejar tanto na construção de 
uma boa lida com a solidão quanto na construção de laços de qualidade com o outro. Seria um recurso insuficiente e empobrecido para vivenciar ambas as experiências, a de se estar aprazivelmente só e também a de trocar verdadeiramente com alguém. Seguiremos explorando essa problemática ao longo do capítulo.

Para finalizar essa seção em que nos dedicamos diretamente à solidão e a seus entrecruzamentos com o advento da internet, desejamos apenas indicar dois fenômenos que vêm ganhando destaque nesse universo, chamando a atenção da sociedade e de intelectuais de toda sorte, incluindo os psicanalistas. São eles: a pornografia e o suicídio. Guardadas as especificidades de cada um dos temas, que obviamente se distanciam em diversos aspectos, localizamos em ambos dois pontos em comum, que nos interessam diretamente em nossa pesquisa: tanto o recurso ao pornô quanto a prática de tirar a própria vida eram experiências vividas mais solitariamente do que o são hoje em dia. Além disso, ambas passaram a ocupar um espaço considerável do mundo cibernético. À luz de nossos estudos, o que poderíamos pensar a respeito do "suicídio compartilhado" via web? Que novos elementos esse novo fenômeno contemporâneo acrescenta às reflexões a respeito da solidão e do laço com o outro em tempos de conectividade? Por outra via, como Freud e Lacan e o que trazem sobre essas temáticas podem ajudar no entendimento dessa prática chocante, que gera horror e perplexidade?

Com relação à discussão em torno da pornografia digital, destacamos do que nos trazem Veras (2015) e Santos (2016) - psicanalistas que se debruçaram sobre o tema -as articulações que fazem entre o pornô e a solidão. Veras (2015a) trabalha a "solidão pornográfica", apresentando-nos uma zona solitária em que situa o universo pornográfico e seus masturbadores adictos. Diante da "oferta virtual maciça ao alcance dos dedos" (Veras, 2015a, p. 13) e do "imperativo de pornografia para todos" (idem, p. 18) muitos sujeitos "se reduzem a ser um consumidor de sua pílula diária de pornografia doméstica" (Veras, 2015b, p. 205). Santos (2016) define a internet "como um Buffet 24-horas "coma-à-vontade", que

\footnotetext{
${ }^{5}$ Indicamos a leitura desta esclarecedora entrevista a respeito do tema: "Há um centro de valorização da morte na internet", em que o psicanalista Mario Corso posiciona-se frente ao fenômeno de incitação ao suicídio que circula pela rede. A fala de Corso tem como disparador o caso de Yonlu, paciente que atendia e cuja história trágica tornou-se inclusive um filme. O suicídio de Amanda Todd, popularizado através da rede em 2012 é outro exemplo de espetacularização da própria morte via internet. Cabe mencionar ainda a formação de clubes de suicídio que se espalham pela internet, com casos particularmente chocantes no Japão, onde é possível combinar serviços de suicídio coletivo para baixar custos e evitar encargos aos familiares.
} 
serve todo tipo de aperitivo sexual" (Santos, 2016, p. 68), sublinhando o fácil acesso que se tem a um material que antigamente era secreto. Apresenta estatísticas recentes que sugerem uma correlação entre o consumo de pornografia e o aumento dos casos de disfunção erétil entre jovens - "os jovens estão devorando, e sendo devorados" (idem) - para em seguida relatar depoimentos de alguns deles que, sentindo-se ameaçados em sua virilidade, decidiram parar de assistir vídeos pornôs para procurar mais relações sexuais. Segundo Santos (2016) "ter a fantasia pré-fabricada e ao alcance do bolso implica em se defender do encontro sexual com o parceiro - encontro este que é sempre faltoso- e optar pela aquisição de um objeto disponível no mercado" (Santos, 2016, p. 69). Em linhas gerais, estes autores parecem apontar para o fato de que a disponibilidade do sexo via pornografia on-line contrasta enormemente com os embaraços que todo sujeito encontra na procura, digamos, mais convencional, por um parceiro sexual. Entre o "fácil" e o "difícil" tendemos a escolher o primeiro, daí o sucesso planetário deste ramo do mercado digital.

\title{
3.3) Uma rede que faz laço, uma rede que isola
}

\author{
Atualmente, inseguros em nossas relações e \\ ansiosos sobre nossa intimidade, olhamos para a \\ tecnologia buscando caminhos para estar em \\ relacionamentos e nos protegemos dos \\ relacionamentos ao mesmo tempo.
}

Sherry Turkle, Alone Together

Nesta seção procuraremos investigar quais as incidências da internet no laço com o outro. Sabemos que a construção de redes de comunicação entre as pessoas é um hábito comum e antigo, mas, quando se criam e se proliferam entre nós essas "novas redes sociais" (Anzalone, 2014), estas que surgem a partir do mundo cibernético, há uma mudança de cenário. A rede virtual possui uma natureza distinta, o que, por si só, produz muitas transformações e inquietações, as quais perseguiremos agora. Como o próprio título que criamos para nomear esta discussão indica, partimos do princípio que a rede pode promover tanto a construção de laços quanto o isolamento. Em si mesma ela não é ou uma coisa ou outra e nesse ponto concordamos com os autores que a definem como "um mundo de possibilidades" (Nobre e Moreira, 2013, p. 287). Se o efeito que o uso da 
internet produzirá na vida de um sujeito é de ampliação de suas relações amicais e amorosas ou de redução das mesmas, isso dependerá de inúmeros fatores de sua história pessoal. Chegamos a essa posição a partir da leitura de diversos autores, da reflexão animada pelas ideias por eles levantadas, em diálogo permanente com o material recolhido da prática clínica. Nas linhas que se seguem, desejamos então apresentar os argumentos existentes no campo psicanalítico sobre o tema, na tentativa de explorar os interessantes aspectos que pesam ou para o lado de uma rede que faz laço, ou para o lado de uma rede que isola.

Propositalmente, escolhemos iniciar esse debate pelo pensamento de Sherry Turkle, tanto por sua importância e pioneirismo nesse campo de estudos quanto pelo fato desta polêmica ter sido por ela apresentada e desenvolvida. Psicóloga e professora do M.I.T Boston Massachussets, antropóloga, pesquisadora e autora de diversos livros, de sua vasta e consagrada obra optamos por nos dedicar às ideias centrais do livro "Alone Together: why we expect more from technology and less from each other ${ }^{6 "}$ (2017a). Segundo a autora esta obra completa sua trilogia sobre computadores e pessoas, composta ainda por "The Second Self" e "A Vida no Ecrã”. Se já fora otimista e cheia de esperanças sobre a comunicação digital, não está mais, o que observamos com clareza no Alone Together, livro no qual a autora se mostra preocupadíssima.

Ela nos conta que antes da pesquisa para esse livro era uma "entusiasta da cultura digital" (Turkle, 2017a, p. xx). Posteriormente, passou a ter uma posição mais cautelosa. Acompanhando seus passos, nota-se que até certo momento se interessava em explorar a relação de uma pessoa com o computador e que, em seguida passou a investigar de que modo as pessoas se relacionam umas com as outras usando o computador como um intermediário. Em suas palavras, "pensar sobre a conectividade é um modo de pensar sobre o que significamos uns para os outros" (idem, p. xvii). O pressuposto do qual parte - central também para nossa pesquisa - é que nossos relacionamentos mudaram com a tecnologia.

O cenário atual a faz afirmar que a tecnologia aumentou o isolamento social. Para ela a presença da comunicação digital pode ser associada a certa diminuição da empatia nos relacionamentos humanos. O tom que utiliza é quase

\footnotetext{
${ }^{6} \mathrm{O}$ livro ainda não possui uma tradução para o português. Encontramos a tradução francesa, transcrita a seguir: "mais e mais tecnologia, menos e menos relações humanas". O que nos chamou a atenção foi que, se no inglês já aparece uma certa alusão a uma balança, que se pende mais para um lado, deixa a desejar do outro, no francês isso está mais que evidenciado.
} 
ácido, a ponto de comparar a internet à Coca-Cola: "A tecnologia nos trouxe essa água açucarada e gaseificada e levamos cem anos para perceber que nos faz mal. Ao mesmo tempo em que a declaramos como algo tóxico, ela está integrada ao "American dream"” (p. xxii). É taxativa em afirmar que não podemos esperar, precisamos agir desde já para evitar mais efeitos nocivos. "Estão brincando com fogo" (p. xxv); "Como chegamos a esse ponto e estamos contentes de estar nele? (p. 02). Sustenta que estamos vivendo uma reviravolta, que estamos em um "novo nível" com relação às expectativas que criamos frente à tecnologia. Em suas palavras: "Nos inclinamos para o inanimado com uma nova solicitação. Tememos os riscos e desapontamentos provenientes das relações com nossos companheiros humanos. Esperamos mais da tecnologia e menos do outro" (p. xii).

O que pensar dessa afirmativa contundente de Turkle em diálogo com o que trabalhamos nos capítulos anteriores da tese? O emprego dos advérbios "mais e menos" tendem para uma polarização. Ao mesmo tempo, no subtítulo de seu livro, Turkle expressa essa ideia através de uma pergunta: porque esperamos mais da tecnologia e menos das pessoas? Arriscando-nos humildemente a respondê-la, tomando como base os ensinamentos de Freud e de Lacan a respeito do laço com o outro esmiuçados no capítulo anterior, diríamos: porque já sabemos que das pessoas não podemos esperar muito! A própria autora comenta isso na abertura de seu livro: "Porque conversas face-a-face são difíceis. Desajeitadas, embaraçosas, espontâneas, bagunçadas, sem script" (p. xxii)". O que de nossa parte parece mais interessante de ser sublinhado é o caráter de tensão, de potencial desencontro, intrínseco às relações interpessoais. Dado que vivemos defrontados com esse desafio e que a ciência nos apresentou essa novidade, tentamos ver se com a tecnologia podemos encontrar mais harmonia e completude e menos decepções e falta de reciprocidade. Nutrimos a esperança de que nos relacionando com um outro não dividido - o computador, o smartphone - talvez experimentemos relações menos conflituosas, mais garantidoras de felicidade. Voltaremos a essa discussão fundamental mais adiante, especificamente em dois tópicos: no que situa a presença do real (no sentido lacaniano) no mundo virtual e naquele em que indagaremos o estatuto desse(s) outro(s) com os quais interagimos no universo on-line.

Em entrevista concedida a psicanalistas lacanianos da ECF - École de La cause freudienne de Paris- Turkle reafirma suas críticas à hiperconexão, em 
postulações como essas: "A tecnologia nos encoraja a esquecer da importância das discussões em tempo real” (Turkle, 2017b, p. 133); “O computador oferece a muitas pessoas o sentimento de uma companhia sem as exigências de uma amizade, sem as exigências da intimidade" (p. 132). Parece dizer, de modo obviamente mais sofisticado, o mesmo que nos disse a garotinha de cinco anos com quem dialogamos a respeito do assunto: "As pessoas ficam no computador para descansar um pouco. Porque ficar o tempo todo com o outro cansa!". Cada uma a seu modo, referem-se à dupla-face do outro, ao papel complexo que opera em nossas vidas, já que, ao mesmo tempo em que nos aquece e nos permite a experiência do encontro, nos exige um esforço e, ainda assim, não anula nossa fragilidade e nossa finitude.

A expressão alone together, a qual Turkle escolhe para caracterizar o estado em que nos encontramos hoje em nossos relacionamentos, nos suscitou um questionamento a respeito do quão sozinhos ou juntos estamos na atualidade, mas também sobre essa tensão entre solidão e companhia antes de que existisse a internet. O ponto que desejamos destacar é o seguinte: dizer que o que nos leva a estarmos juntos e sozinhos (ou seja, que estamos lado a lado, mas sem um compartilhamento efetivo) é a internet, talvez leve a crer que uma "verdadeira irmandade", um estar "junto-junto" seja possível. Parece-nos que a afirmativa de Turkle está carregada de um tom romântico em direção ao passado das relações, tom com o qual não comungamos. Lacan em "O seminário 17", nos ajuda a embasar um posicionamento que nos parece bem interessante. Em passagens onde esclarece a forma como o pensamento psicanalítico compreende o laço possível entre as pessoas, diz coisas como: "as energias que empregamos em sermos todos irmãos provam bem evidentemente que não o somos"; "Essa obstinação com a fraternidade (...) é coisa ridícula, que seria conveniente captar o que recobre"; "Nenhuma outra fraternidade é concebível, não tem o menor fundamento, se não é por estarmos isolados juntos, isolados do resto" (Lacan, 1969-70/1992, p.107). Se nos anos setenta do século passado, quando nem sonhávamos com a existência dessa potente rede de comunicação, Lacan já nos definia como "isolados juntos", é porque ao menos parte dessa condição é um fato de estrutura. Fato este, aliás, já revelado por Freud, como nos esclarece a seguinte formulação: "Freud já dizia que o primeiro mandamento era amar o próximo porque nosso desejo primário era aniquilá-lo" (Gueller, 2017, p. 75). 
Que nossos relacionamentos mudaram com a tecnologia, com isso estamos de acordo. Contudo, de nosso ponto de vista, trata-se de mudanças um pouco mais sutis, salvo em alguns casos, nos quais o uso das tecnologias se dá em níveis extremos (como veremos adiante com os hikikomoris no Japão, por exemplo). Enquanto psicanalistas, pensamos ser mais interessante focarmos nas nuances, atentarmos para as sutilezas, do que fazermos coro com visadas mais generalizantes e extremadas sobre fenômenos da cultura. Quando o assunto são os laços que estabelecemos, a contribuição singular que a psicanálise tem a fazer é sublinhar (dentre outros aspectos) o quanto o caminho em direção à união é fruto de um esforço frente à agressividade da qual somos dotados. Como bem coloca Flanzer (2004): “Qualquer tentativa de irmandade (...) nada mais seria do que uma consequência da já abalizada estrutura do sujeito, sua tentativa de inebriar o real que já está ali, por assim dizer, embrenhado no osso" (Flanzer, 2004, p. 159).

Dessal (2017b) também parte da força presente no alone together ${ }^{7}$ de Turkle para introduzir uma de suas palestras sobre internet e subjetividades, intitulada com a pergunta "conectados ou desconectados?". Segundo a visão do psicanalista espanhol, a técnica nos levou a esse estado ao qual Turkle nomeou de "solos juntos". Seu objetivo ao retomar a autora e ao nomear assim sua palestra é enfatizar o paradoxo. Em suas palavras: "A hiperconectividade, que inaugurou inumeráveis comunidades por todo o planeta, reunidas em torno de todo tipo de signos identitários, e que permitiu que sujeitos isolados de qualquer vínculo encontrassem um alojamento na magia das redes sociais, é, paradoxalmente, o que também nos separa, cria uma barreira invisível, um filtro difícil de atravessar. A presença real vai convertendo-se em algo estranho, invasivo" (Dessal, 2017b, p. 13). Sendo assim, a virtualidade poderia influenciar negativamente o exercício de interagir presencialmente com o outro. Para os autores que avaliam o nível do contato e envolvimento com o outro permitido pelas mídias como menor do que o presencial ocorre a criação de um cenário emocional árido com consequências como o empobrecimento dos laços afetivos, o esvaziamento da comunicação e a criação de subjetividades frágeis e incapazes de lidar com demandas relacionais.

Tal ideia nos remete uma vez mais às reflexões levantadas por Turkle em seu livro, de que estamos substituindo a interação social pela tecnologia, de que

\footnotetext{
${ }^{7}$ No artigo "A solidão dos hiperconectados" Veras (2019) também menciona estarmos "juntos $e$ separados" (grifo nosso) (p. 50) nessa aldeia global hiperconectada.
} 
estamos usando muita mediação ao invés do contato direto. Seu argumento é de que o uso da internet tem mais poder de isolar e destruir relacionamentos do que de nos fazer ficarmos juntos. Suas pesquisas a levaram ao entendimento de que o que era para ser uma maneira de facilitar a comunicação, empurrou as pessoas para mais perto de suas máquinas e para mais longe umas das outras. Transcrevemos a seguir uma série de assertivas complementares da autora, que fortalecem seu ponto de vista: "estamos dando qualidades humanas a objetos e tratando humanos como coisas" (Turkle, 2017, p. xiv); "a rede está com a gente, na gente, o tempo todo ${ }^{8}$. Logo, podemos estar com os outros o tempo todo" ( $p$. xii); "Nossas vidas 'sempre ligados /sempre ligados em você' promete que nós nunca precisamos nos sentir sozinhos, que alguém sempre pode nos escutar. Mas a "vida social online o tempo todo" construiu limitações. O mais importante: estamos tentados a nos desligar das pessoas com quem estamos juntos para nos conectar aos prazeres de nossos telefones" (p. xxi), ou seja, "estamos mais distraídos na presença de outra pessoa" (idem).

Abrimos aqui um parêntese para comentar algumas ideias interessantes apresentadas pela jornalista Rosana Hermann no livro “Celular, doce lar” (2018), já que, a nosso ver, dialogam com as críticas de Turkle transcritas acima. Com um título que por si só já é provocativo, a autora intenciona convocar seus leitores a discutir essa relação que têm com seus smartphones, já que passaram a "viver no seu telefone". Hermann afirma que não tem como objetivo demonizar o celular. Coloca-o na berlinda por considerar necessário que reflitamos sobre esse novo "lugar" onde todos estamos morando, com o qual estabelecemos uma relação tão intensa. Nesse diálogo com Turkle ao qual nos propomos agora vale apresentar uma das percepções fortes da jornalista a respeito da interferência dos celulares nos encontros presenciais que travamos uns com os outros. Segundo ela, como no aparelho tem pessoas muito mais interessantes do que aquela(s) com quem estou ali de fato, tendemos a nos desligar daquele contato ao vivo para mexer no celular. A esse respeito Turkle cita em sua obra pesquisas cujos dados revelam o seguinte: $89 \%$ dos americanos dizem que interromperem sua última interação social para olharem o celular e $82 \%$ disse que a conversa foi prejudicada por isso (Turkle,

\footnotetext{
${ }^{8}$ Laurent (2010), ao dedicar-se à problematização desse mesmo aspecto, propôs nomear os chats como "Outro infinito da interlocução" (grifo nosso) (Laurent, 2010, p. 20).
} 
2017, p. xxi). Por conta desse comportamento que de fato é tão pregnante na atualidade foi criado um novo hábito, uma espécie de jogo para fazer frente a isso, em clima de brincadeira: quando saem para restaurantes os amigos sentados à mesa colocam seus celulares no centro, ligados. Aquele que não resistir e for o primeiro a pegá-lo para checar, paga a conta. Essa visão sobre os aparelhos de telefone celular como algo que age em detrimento do meu contato com o outro, voltará a ser debatida na seção 3.7, onde questionaremos se tem havido, na contemporaneidade, uma substituição de pessoas por máquinas no campo relacional.

Se a ênfase de Turkle recai sobre uma rede que isola, se denuncia os celulares como aparelhos que permitem que "estejamos ali, mas não estejamos" existem, em contrapartida, diversos autores que destacam a potencialidade das redes digitais de promoverem o laço, de fomentarem os relacionamentos interpessoais. Desde esse ponto de vista, as redes virtuais são espaços legítimos de conversação que ampliaram as possibilidades de comunicação, produzindo conquistas inegáveis no campo social. Passemos então para os argumentos dos autores que sustentam tal posição, em grande medida contrária à apresentada até aqui nesta seção. Mena (2017) afirma sem pestanejar que "o laço social também passa pelos gadgets" (Mena, 2017, p. 219). Esse psicanalista parte de uma situação vivenciada em sua clínica para ilustrar sua afirmativa, situação protagonizada por um paciente de 14 anos cuja mãe insiste para que desligue o computador e procure algum amigo. Para esta mãe que considera que o filho está vivendo numa "solidão digital" (sic) é dada a seguinte resposta: seria uma falsa solução, pois todos os amigos estão conectados ao computador também. No caso deste jovem (e de inúmeros outros pelo mundo afora) é costumeiro o hábito de receber um amigo em casa, o qual traz seu laptop, liga-o ao lado do seu e "ficam jogando cada um em sua máquina. Separados, mas juntos" (idem). O uso distinto da mesma expressão nos instiga e convida ao aprendizado de que este e outros adolescentes e adultos não estão sempre sozinhos ou isolados quando estão conectados. Ao contrário, "muitas vezes se trata mais de uma dependência ao laço social do que sua recusa" ressalta Mena (idem). Essa multiplicidade de usos e efeitos subjetivos nos interessa muitíssimo.

Mantendo-nos neste universo dos adolescentes (os nativos digitais) encontramos em uma das falas da "Polegarzinha" (figura criada pelo filósofo 
francês Michel Serres para personificar os integrantes dessa nova geração) outro argumento a favor da sociabilidade via meios virtuais. Sendo (porque não?!) freudiana ao partir do princípio de que nos machucamos tal como os porcos espinhos na lida com o outro, indaga aos mais velhos: "Não acham prudente se aproximar dos outros de maneira virtual para, já de início, machucá-los menos?" (Serres, 2013, p. 71). Defendendo os hábitos comuns à sua faixa etária alfineta os adultos, aqueles que os criticam: "Provavelmente temem que, a partir dessas tentativas, surjam novas formas políticas que afastem as anteriores, obsoletas. Obsoletas, sem dúvida, e tão virtuais quanto as minhas: exército, nação, igreja, povo, classe, proletariado, família, mercado... são abstrações, pairando acima das cabeças, como fetiches descartáveis" (idem). É interessante essa alusão às complexidades existentes entre real e virtual (trabalhadas na seção 1.6 desta tese) como uma das formas de positivar o uso da virtualidade no estabelecimento de laços.

A internet como lugar de experimentação figura como mais uma forma de apresentar a rede segundo esse viés de ampliação das possibilidades. Sobre isso, Leduc (2016b) dedica-se a pensar a respeito da forma como os adolescentes a utilizam, fazendo dela um lugar de intimidade, onde fazem o que tem que fazer sem os adultos, para se construírem separados deles (Leduc, 2016b, p. 03). Sobre essa importância que pode ter a internet no processo de construção da identidade de um adolescente Lima (2017) aponta as redes sociais como ferramenta que pode "operar como um rito de passagem, favorecendo o desligamento dos pais e levando a novas identificações" (Lima, 2017, p. 83). Santiago (1997), por sua vez, sublinha o fato de que a internet fez surgir novas formas de convivência grupal. Partindo de situações em que adolescentes sofreram algum tipo de sofrimento ou recusa no campo social, a psicanalista defende que "a internet e toda a diversidade das redes digitais, ridiculamente temidas como lugar de indiscriminada perdição e encontros perigosos, torna-se, de fato, o lugar virtual em que esses indivíduos [adolescentes] exercem um certo esboço de reconstituição do laço social" (Santiago, 1997, p. 75).

Em entrevista concedida ao grupo de pesquisas "Além da tela", em março de 2017 (publicada em 2018) por ocasião do “1 Simpósio Internacional Subjetividade e Cultura Digital: Corpo e Virtualidade", o antropólogo francês David Le Breton sinaliza que as redes podem ser usadas pelos adolescentes, 
sobretudo, como "uma forma de se experimentar" (Le Breton, 2018, p. 301). Em um contexto mundial de mutações e migrações, "a rede é uma solução, uma ferramenta para encontrar seu lugar no mundo. A rede é uma forma de se inventar em um diálogo com os outros. Por isso que é uma experimentação, uma criação, uma inventividade" (idem, p. 303). Em artigo anterior Le Breton (2017) amplia o leque de possibilidades das funções que o uso da rede pode ter para cada um, nessa fase específica da vida. Enquanto para alguns a internet é propícia para a "construção de si", para outros funciona como uma alternativa para a vida real, uma proteção contra as ambivalências do mundo. Cita a prática usual do uso dos fones de ouvido, através da qual os adolescentes se "desligam" do cotidiano, vivendo numa "espécie de autossuficiência tecnológica, curvados sobre eles mesmos, uns ao lado dos outros, dedicados a digitar em seus celulares ou a dedilhar uma mensagem" (Le Breton, 2017, p. 16) (grifo nosso). O autor analisa os celulares como aparelhos que promovem "uma conexão permanente com o grupo de pares e, ao mesmo tempo, uma fronteira com o resto da sociedade" (idem, p. 17) (grifo nosso).

Desta interessante abordagem do antropólogo destacamos o fato de que ele apresenta e argumenta sobre gradações no uso das redes. Ao mesmo tempo em que fala dessa experimentação, discute o uso da internet como forma de total desparecimento de si, como ocorre em casos radicais, tais como os de suicídios transmitidos ao vivo pela web ou dos hikikomoris japoneses (exemplo que trabalharemos a seguir). Além desses digamos, extremos, Le Breton nos fala da existência de jovens que se situam no "meio do caminho", ou seja, aqueles que ainda comem e mantêm encontros com os amigos, "de vez em quando". "São jovens que têm uma vida social, mas que são, em suas vidas, completamente absorvidos pelos videogames e pela internet” (Le Breton, 2018, p. 308). Passam dez a doze horas por dia na frente da tela e, nesses casos, "há uma maneira de desaparecer de si multiplicando os apelidos, multiplicando os personagens" (idem). Um jovem lhe disse que "tinha uma dezena de apelidos na internet com os quais se alegrava, mas que tinha apenas uma identidade que ele não suportava: aquela que tinha um corpo" (idem).

Talvez possamos interpretar que para alguns sujeitos, como o referido acima, estar mergulhado no cyber universo, é um movimento necessário para a construção processual de uma identidade, movimento que pode vir a culminar na 
construção de laços mais satisfatórios do que os que se tinham anteriormente. Tal atitude, comumente interpretada como fuga e como prejudicial à sociabilidade, seria, na verdade, parte de um processo singular de inserção no coletivo. Estremecendo-se inicialmente e temporariamente um laço com os colegas de classe, construir-se-íam, a posteriori, muitos outros vínculos de amizade. Afastando-se dos pais ao trancarem-se nos seus quartos ligados a seus aparelhos, redesenhariam, assim que possível, uma relação filial a partir de outro lugar. Novamente nos deparamos com as complexidades instigantes do tema de pesquisa dessa tese. Quais as consequências da inclusão dos objetos digitais na clássica cena dos adolescentes que fazem de seus quartos suas casas? Há diferenças consideráveis no fato de que se trancam e se separam de seus pais ligando-se simultaneamente à rede virtual? Independente da resposta a que cheguemos para tais questões, é preciso ressaltar que um mesmo hábito, um mesmo comportamento, pode querer dizer coisas opostas, dependendo do sujeito.

Essa ideia de que a criação do universo digital trouxe um lugar a mais para a socialização, ou seja, de que a internet se soma a outros recursos a que temos acesso para nos relacionarmos uns com os outros é veiculada por diversos autores. E, é importante notar, que é uma ideia que se estende a outras faixas etárias, ou seja, não se aplica exclusivamente aos adolescentes. Nobre e Moreira (2013), assim como outros pesquisadores do "Além da tela", apresentam essa perspectiva, em formulações tais como: "O ciberespaço é o ambiente em que se configura essa nova forma de realidade social (...) suporte para novo âmbito de ação e experimentação para a subjetividade" (Nobre e Moreira, 2013, p. 285). Enfatizam o "novo" e também o "a mais": "é mais um meio de socialização e de trocas afetivo-sexuais" (idem, p. 286). Romão-Dias e Nicolaci-da-Costa (2005), por sua vez, apresentam o uso da internet como forma de brincar com as outras pessoas ou de testar a si mesmo, apresentando a possibilidade da 'net' servir para alguns "como um laboratório de comportamentos" (Romão-Dias; Nicolaci-da-Costa, 2005, p. 82). Propõem que se pense a internet como um lugar para o brincar (no sentido winnicottiano), "um lugar para o viver criativo, um lugar para se sentir vivo" (Romão-Dias; Nicolaci-da-Costa, 2012, p. 97), tendo, portanto, um efeito enriquecedor.

Mantendo vivo o debate sobre "uma rede que faz laço, uma rede que isola" extraímos de uma das comunicações do sociólogo Zigmunt Bauman sobre a 
internet uma formulação que nos interessou particularmente. Vale comentar que Bauman, assim como Turkle, tem figurado como um dos autores que criticam negativamente as redes por considerá-las como uma das responsáveis pela liquidez das relações na atualidade. Eis a crítica que nos chamou atenção em nossa pesquisa: "nas redes sociais, contatos (são) rebatizados como amigos" (Bauman \& Dessal, 2017, p. 40). A esse respeito, diríamos que essa equivalência entre o número de contatos ou de seguidores que se têm nas redes ao número de amigos que de fato se têm na vida pode comparecer, sim, para alguns sujeitos, mas, certamente não para todos. Parece-nos que grande parte dos usuários das redes sociais já está sabendo distinguir que há diferenças importantes na natureza e na intensidade de cada um desses tipos de troca.

A pergunta esboçada por Anzalone dá prosseguimento a essa discussão: "Qual é o conceito de amizade que temos em nossos dias?" (Anzalone, 2018). Em seus artigos, o autor avança, trazendo novos pontos de reflexão, como o pensamento acerca do "grau de separação" e do "grau de proximidade" entre os seres humanos do mundo. Problematiza essas duas dimensões, considerando que podemos estar menos separados, ou seja, com menos fronteiras (como as distâncias geográficas) entre nós, mas nem por isso necessariamente mais próximos. Se por um lado, demarca aqui que há limites no poder da rede de nos unir, em outra passagem, atenta, contrariamente, para a característica de vacuidade essencial da rede, que teria surgido "justamente naquele ponto em que o laço social falha, na tentativa de fazer acreditar no impossível do encontro" (Anzalone, 2018, p. 290). Assim, consideramos interessante notar que no interior do pensamento do autor pulsam lado a lado a internet como engodo, como proteção ao real e a internet que nos relança ao enfrentamento do mesmo.

Ao referir-se à clínica, ao que escutamos de diferentes sujeitos, Anzalone demonstra que na prática o sofrimento vem dos mais variados modos, até mesmo de opostos: há sujeitos que sofrem por não ser amados ou os que sofrem por serem muito amados - e isso vira uma obrigação - ou sofrem porque descobrem que seu parceiro (a) também é amado (idem). Há aí, portanto, dor e delícia. O trecho a seguir ilustra bem essas múltiplas facetas: "Resulta inegável seu papel nos encontros e desencontros amorosos atuais, seja porque cada vez mais pessoas se conhecem por meio das redes sociais, mas também porque cada vez mais 
relacionamentos terminam pelas próprias redes. As redes têm se convertido no veículo privilegiado para expressar nossas alegrias e sofrimentos” (idem, p. 291).

Nessa tensão permanente entre uma rede que nos alivia da solidão e uma rede que nos faz re-experimentá-la, oferece outras situações cotidianas, que nos fazem rir e aprender ao mesmo tempo. Ao falar da ocasião em que perdeu seu celular, comenta sua dupla frustração: "não somente experimentava o sofrimento específico da perda do gadget, senão que me via privado da possibilidade de expressá-lo em uma rede social! De que vale sentir felicidade ou sofrimento em nossos dias sem que o gigante nos veja, nos aplauda, nos mime? Quem pode se sentir sozinho se estamos sempre acompanhados por ele?” (idem). A respeito dessa interferência da "plateia virtual" em nosso sentimento de solidão analisa também as curtidas das fotos e posts que compartilhamos, caracterizando-as como "signo de amor (...) que parece nos proteger do sofrimento pela falta de amor, em especial da solidão" (p. 290).

Focando agora na possibilidade que as redes virtuais têm de alimentar ou produzir isolamento, desejamos atentar para um ponto que nos surpreendeu ao logo da pesquisa. Se, a princípio, o que fica exaltado na era da hiperconexão é justamente a conexão, ou seja, a possibilidade da companhia ininterrupta, observando mais de perto se destacou para nós a facilidade com que nos retiramos da interação com alguém, com que nos desconectamos, portanto. Nesses anos de pesquisa ouvimos de muitos usuários da internet que a grande novidade das redes é a facilidade de se desconectar e não a de se conectar. $\mathrm{O}$ que seria realmente inédito e transformador das relações seria o fato de não precisar responder, ou seja, a capacidade de deletar, de deixar de seguir, de bloquear um contato, de cancelar alguém. Terminar qualquer tipo de troca, de relação com o outro - das mais superficiais às mais profundas - sem ter o trabalho de se despedir é realmente uma marca de nossos tempos. Esse novo e instigante fenômeno vem interessando alguns intelectuais contemporâneos, cujos pensamentos expomos a seguir.

Para Bauman essa ação de deletar pode ser definida como "atributo indelével dos laços mediados eletronicamente” (Bauman \& Dessal, 2017, p. 42). Dunker (2017b) considera que "a vida virtual criou novas formas de amar e desamar" (Dunker, 2017b, p. 120). Traçando um paralelo crítico entre os diferentes modos de interromper um laço com alguém, afirma que "na vida em 
formato de videogame aprendemos muito sobre como deletar pessoas, mas pouco sobre a arte de desistir, despedir e guardar as fotos de recordação, com carinho e gratidão" (Dunker, 2017b, p. 47). Afim de abordar esse mesmo aspecto Veras (2019a) nos apresenta o recente fenômeno apelidado de vácuo, que tornou-se constante nos aplicativos como Tinder, Par Perfeito ou Grindr: os casais se formam por aplicativos e começam o diálogo; quando as coisas apontam para um verdadeiro encontro ou para um relacionamento mais prolongado, um dos dois simplesmente sai da conversa e deleta o contato, sem desculpas, pedido de separação ou mesmo um simples "até logo". A esse respeito, conclui o psicanalista: “As relações construídas virtualmente são muito mais voláteis, basta um clique para que o interlocutor desapareça para sempre. (...) Nas relações virtuais tornou-se possível o sonho de um fim de relacionamento sem restos. É possível se “deletar" da cena" (Veras, 2019, p. 50).

Há ainda outro aspecto que desejamos ressaltar na interação via internet que não corrobora com o frisson de que a rede nos serve apenas ou majoritariamente como um playground para a conversa fiada e divertida. Estamos nos referindo à faceta da rede que desfaz laços pré-existentes, entre amigos e familiares, por exemplo, na medida em que produz conflitos entre os mesmos, que possivelmente não ocorreriam fora de certas plataformas digitais. Quantos de nós não experienciamos brigas por Whatsapp, em relação às quais concluímos um tempo depois que se deram por um mal-entendido próprio ao modo de troca por escrito, sem o tom, sem o semblante de quem está do lado de lá da conversa?

Sobre isso, interessado especificamente no forte potencial desruptivo presente no Facebook, Lyra (2019b) explora o que seriam as conversas vocábulo intencionalmente grafado pelo autor em itálico - nessa rede social. De saída, quer dar notícias de que não são conversas como outras quaisquer, há particularidades aqui presentes. Nesse texto-denúncia, a mensagem deixada pelo autor é a de que fiquemos "atentos à degradação das trocas promovidas pelas redes sociais" (Lyra, 2019b, p. 03), visto ser "evidente que a prioridade da rede social não é tanto apoiar a possibilidade de "escolhas informadas", mas garantir que a máquina de conversas siga se multiplicando" (p. 02). Como para seguir existindo "o Facebook se nutre de conversas" (p. 01), "não se trata do aumento de reações individuais e autênticas a conteúdos que interrogam, mas de interações provocadas, que tendem a circular dentro do labirinto algorítmico feito para atiçar 
rivalidades, privilegiar mensagens apelativas e favorecer a caricatura das posições a partir das quais cada um enuncia a sua fala" (p. 02). O autor salienta que o debate público não era fácil ou sempre produtivo antes que as redes sociais pautassem as democracias ocidentais. "Produzir uma conversa produtiva sempre foi e sempre será um desafio, em qualquer contexto" (p. 03). "O que inquieta, no entanto, é que as plataformas que hoje estruturam o laço social (...) expressem a valorização de uma suposta conversa marcada, desde a saída, pelo sensacionalismo e pela polarização" (p. 03). Lyra frisa, portanto, que estamos assujeitados a uma máquina que tem intenções próprias, o que nos transforma em "usados" e não "usuários". Vemos nas colocações deste autor a inserção de mais um ingrediente que faz a rede pender mais para o lado do isolamento do que da construção de laços.

No esforço de seguirmos problematizando o fenômeno das redes virtuais, explorando suas diversas nuances, focaremos agora na atração que a web produziu em determinados públicos. Para aqueles sujeitos que, respeitadas as suas particularidades, encontravam-se fora dos ditos padrões de sociabilidade atuais e que, por isso, tinham dificuldades de estabelecer laços sociais do modo "convencional", a rede veio, sem dúvida, como um grande recurso. Refiro-me aos autistas, psicóticos, idosos, tímidos, obesos, adolescentes vítimas de bullying, outsiders, ou seja, aos que, de forma geral, por um motivo ou por outro, viviam a convivência com os demais como um pesado desafio. No transcorrer da pesquisa nos chamou a atenção a criação de páginas em redes sociais por pessoas portadoras de doenças raras como a de uma colega que sofre de retinose pigmentar. Acompanhando suas postagens percebemos que ali, pela primeira vez, a moça pôde não só expor essa sua fragilidade como também receber apoio, seja de amigos que não sabiam dessa condição, seja de desconhecidos acometidos pelo mesmo mal. A longa internação hospitalar de um colega de infância e o uso frequente que fez do Facebook também nos impactou enquanto pesquisávamos o tema. Era nítida a importância que iam tendo para ele os depoimentos que escrevia a respeito de seu quadro clínico instável. Os efeitos desse ato decorriam tanto do exercício da escrita propriamente quanto do endereçamento via rede social àqueles que lhe queriam bem. Do mesmo modo, as mensagens de carinho $\mathrm{e}$ a torcida para que se recuperasse tinham efeitos consideráveis para o adoentado. São exemplos de laços estabelecidos via rede que não tinham como existir antes 
dela. Laços inéditos, bonitos, vivificantes e que passaram a existir graças à internet ou que, poderiam ter existido, mas não com o alcance e potência que hoje os sustentam.

Nesse sentido, a tese de Wainstock (2013) a respeito dos enlutados que trocam entre eles se destaca, ao dissertar sobre esse tipo de novidade advinda junto com a rede, de poder existir troca e alguma sensação de estar acompanhado em momentos de tanta solidão como o do luto pela perda de um ente querido. Em "Filhos que vão, pais que ficam: a web como recurso de comunicação durante o luto" (2013), a pesquisadora nos apresenta o fenômeno do "luto virtual", o qual surgiu com a criação de comunidades no Orkut por pais enlutados que sentiram a necessidade de compartilhar a sua dor com outros que passaram por experiências semelhantes. A pesquisa indicou que "se a dor de perder um filho parece se assemelhar a uma sensação de "cair em um abismo", as comunidades virtuais para pais enlutados funcionam como "cordas de resgate"” (Wainstock, 2013, p. 06). Nesse sentido, complementa a pesquisadora, ter a sensação de proximidade com outros pais enlutados de qualquer lugar, a qualquer hora, faz com que a solidão seja minimizada porque passa a ser compartilhada com aqueles que sofreram o mesmo impacto.

Merece destaque também os grupos de ajuda mútua na internet que, conforme esclarece Campos (2006), são espaços nos quais os usuários podem "dividir sentimentos, percepções de suas dificuldades, "dicas" de médicos, tratamentos, dietas etc. Enfim, podem sentir-se menos sós" (Campos, 2006, p. 141). E por fim, enriquecendo a lista (que por ser absolutamente vasta não se esgota aqui) de exemplos de usos da rede que promovem laços com o outro, citamos apenas algumas situações a mais, como a criação de páginas de pais de crianças portadoras de Síndrome de Down, projetos de "vakinhas" para angariar fundos para tratamentos de saúde ou obras necessárias após calamidades, ou ainda a união, engajamento e empodeiramento de minorias políticas. O comentário de Gueller a respeito desses laços de ajuda possibilitados pelo mundo virtual resume bem do que se trata: "As redes solidárias e a camaradagem que possibilita a internet são de uma potência impressionante" (Gueller, 2017, p. 72).

Dessal (2017b), ao abordar os laços amorosos e familiares no mundo digital, sensibiliza-se por essas possibilidades que destacamos acima, acrescentando a importância de percebermos que já não existe mais uma fronteira 
bem delimitada entre mundo on-line e mundo off-line. Através de argumentos e exemplos, demonstra que assimilar como mundo real apenas o off-line não nos serve mais, não nos ajuda na interpretação do que se passa na sociedade e com os sujeitos que nela vivem. Afirma que o número de pessoas que se sentem melhor e mais confortáveis no mundo virtual aumentou, pois para elas esse mundo "oferece a oportunidade de assumir formas de vida imaginárias, identidades simuladas, fabricadas com a matéria de seus desejos, que interagem com outras formas de vida semelhantes sem penetrarem em riscos demasiados. Para muita gente afetada em sua capacidade para sustentar um laço social de qualquer tipo - amical, amoroso, de pertencimento a um grupo, etc. - a internet criou um espaço aonde alojar-se, um território aonde encontram outros que sentem como seus semelhantes, constituindo assim um tipo de confraternidade nas quais os sintomas e outras desventuras encontram consolo, compaixão, empatia e inclusive legitimidade, a qual lhes é negada no mundo real" (Dessal, 2017b, p. 04). Os exemplos que traz se somam aos que apresentamos há pouco: associações de escutadores de vozes, fóruns de adolescentes youtubers que trocam informações sobre as vicissitudes do mundo transexual.

Especificamente sobre esse universo de pessoas trans ou homossexuais foco de sua pesquisa que deu origem ao livro "Desejos digitais" (2017) - Miskolci salienta o fato de que poder se exibir em busca de admiração e reconhecimento parece uma conquista para esses grupos sociais que ao menos até recentemente haviam sido associados à feiura e ao moralmente disforme. Para eles, entrar online com um perfil, exibir-se em uma foto sensual e fazer parte de um mercado dos afetos foi algo vivido como um grande ganho (Miskolci, 2017, p. 261).

Türcke (2010) se insere nessa discussão enaltecendo os benefícios que a rede pode trazer em outros casos particulares. Segundo o autor: "até mesmo a troca de insignificâncias, cultivada por inúmeros chats, pode ocasionalmente ter seu lado bom, quando ajuda o adolescente e notoriamente tímido a ultrapassar a barreira psicológica para que possam ter seus primeiros contatos. Isso para não falar dos frágeis, solitários e desesperados, para os quais a internet pode tornar-se uma importante ligação com o mundo exterior” (Türcke, 2010, p. 291).

O grau de inserção na rede ou na vida "fora" dela difere, certamente, de um sujeito para outro. Ou mesmo para um mesmo sujeito, irá variar dependendo da idade em que está ou da situação pontual que vivencia a cada época da vida. 
Somente no caso a caso e a par de informações pormenorizadas é que poder-se-á dizer se ali a rede é um instrumento que funciona mais a favor do laço ou do isolamento. Sobre essas gradações, Dessal aborda um fenômeno instigante, o do encontro de uma "família alternativa" (Dessal, 2017b, p. 07) no mundo virtual. Esse termo nos remete à paciente Carolina e ao tom eufórico empregado por ela para dizer de suas trocas com os "sobreviventes de famílias disfuncionais". Em um momento em que estava especialmente mal com sua própria família, de fato relacionar-se com esses novos personagens - "extraterrestres como eu" (sic) - a impactou significativa e positivamente (ao menos em um primeiro momento). Segundo Dessal, "da mesma maneira que uma substância aditiva ou uma crença religiosa podem ser para muitos uma forma de suportar a inclemência da vida que do contrário, tornar-se-ia imanejável - a internet constitui-se para outros tantos como oferta de uma segunda vida, que, às vezes inclusive, converte-se na única aonde podem habitar" (Dessal, 2017b, p. 04, grifo nosso).

Com este autor, percebemos o quanto essa abordagem atenta às sutilezas, não sendo nem generalizante nem polarizadora, é importante para o exercício clínico de um psicanalista. Em seu artigo, Dessal expõe o modo como se posiciona frente aos pais dos adolescentes de sua clínica, dando testemunho de uma postura interessante e inspiradora. Quando lhes transferem suas inquietudes acerca do tempo que os filhos gastam com jogos ou redes sociais e pedem orientações sobre os limites que devem impor, a primeira resposta deste psicanalista espanhol é "conduzi-los a uma pergunta fundamental: o que aconteceria se a internet fosse para algumas dessas crianças e adolescentes algo assim como uma espécie de insulina para a diabetes da alma? Como podemos condenar como uma falta no comportamento, sinal de uma disposição ao vício ou uma manifestação de negligente vagabundagem, o fato de que um adolescente não consegue se separar de seu smartphone ou de seu controle de videogame e experimente como autêntica mutilação a possibilidade de ver-se separado de seus objetos?" (Dessal, 2017b, p. 04). A orientação que transmite nessa passagem parte de uma necessária articulação, ou mesmo adaptação do trabalho do analista ao contexto em que vive. Assim, "na crescente imersão dos seres humanos no universo técnico, se impõe o trabalho preliminar de estabelecer diferenças, de perceber qual é a relação singular que cada um estabelece com seu objeto. Talismã, fetiche, remédio que acalma a angústia, refúgio, conectividade, 
sociabilidade artificial, vínculos de baixo risco, os dispositivos podem oferecer tudo isso e muito mais" (idem).

Dentre as múltiplas ofertas que os dispositivos digitais oferecem, encontramos aquela da adesão maciça à vida $n a$ internet, correlata ao isolamento do convívio social do entorno. Nesses casos o sujeito abandona laços préexistentes, tanto com colegas da escola ou do trabalho quanto com familiares, para relacionar-se apenas através da rede. Vale notar que dentro deste dito isolamento, há algumas variações: há aqueles que realmente cortam o vínculo com os conhecidos e vão em busca de novos pares; há os que seguem se relacionando com pessoas de seu meio, porém exclusivamente pela rede (é um comportamento comum entre adolescentes de séries distintas na escola, que só se falam pelo computador. Ao se cruzarem pelos corredores ou recreio não se falam, mas no contra-turno interagem on-line, animadamente); há os que interrompem as trocas íntimas com outras pessoas e privilegiam relacionamentos com robôs ou namoradas virtuais ou ainda os que se isolam dos demais para viverem em frente às telas "relacionando-se" apenas com conteúdos informacionais que abundam na rede. Para esses últimos, a internet enquanto tecnologia da informação é mais atraente do que por seu viés de comunicação. Preferem (ou talvez, só consigam) dedicar seu tempo e libido a pesquisas de toda sorte, leituras, visualização de posts, séries, filmes, a interagirem com pessoas. Esse nível de sutilezas e distinções estabelecidas pelo autor pareceram-nos importantes a serem pensadas como ferramentas da escuta psicanalítica dos usos que os adolescentes fazem da internet.

Cabe, aqui, lembrar que Freud abordou o comportamento de isolar-se (como vimos no capítulo anterior) na análise que fez da figura do eremita, buscando investigar se esse caminho levaria à felicidade. Segundo o autor: "O deliberado isolamento, o afastamento dos demais, é a salvaguarda mais disponível contra o sofrimento que pode resultar das relações humanas. A felicidade que se pode alcançar por essa via é a da quietude. Contra o temido mundo externo o indivíduo só pode se defender por algum tipo de distanciamento, querendo realizar, sozinho, essa tarefa" (Freud, 1930/2010, p. 32). Aproximará aquele que "rompe todos os laços, dá as costas a este mundo, nada quer saber dele" (idem, p. 37) da figura do louco. Relançando essa reflexão para o mundo mudado em que hoje vivemos e a respeito do qual teorizamos, arriscamos afirmar que o 
isolamento ganhou novas possibilidades, não necessariamente associadas à loucura. Além disso, nesses tempos de "computadorização generalizada" (Dessal, 2017b, p. 02) antes de afirmarmos que alguém está isolado, devemos perguntar: isolado como? Isolado de quem?

Um exemplo loquaz e radical sobre este tema do isolamento é o atual e inusitado fenômeno dos hikikomoris, que ilustra esse paradoxo.

Cada vez mais jovens japoneses decidem ficar trancados no quarto, sem nunca saírem de lá, com a internet ligada sempre e sem outros contatos sociais "reais". Alimentam-se, dormem, defecam, urinam naquele espaço. Esse comportamento extremo, que passou a ser definido como "levar uma vida de hikikomoris", despertou a curiosidade de diversos pensadores pelo mundo afora, gerando caracterizações como: "verdadeiros exilados do laço social" (Anzalone 2014 apud Alba, 2012); aqueles que num dado momento, fazem "uma espécie de greve do laço social" (Le Breton, 2018, p. 307); os que estão "solitários em casa" (Dunker, 2017b, p. 26), que vivem segundo o "isolamento oriental" (p. 27); que experimentam uma "satisfação autística na cultura do quarto" (Fajnwaks, 2019) ou os que "estão em contato com o mundo todo, mas isolados do outro maior, ou seja, o outro que está no eu, seguindo Rimbaud” (Karnal, 2018, p. 182).

Para o antropólogo francês Le Breton, apesar da recusa desses jovens de ver seus pais, seus irmãos, seus amigos, esses "ermitões pós-modernos", como frequentemente os chama, encontram-se inseridos no laço social. Estão em completa solidão em Tóquio, mas dialogam com jovens de Belo Horizonte, de São Paulo, de Estrasburgo e de Vancouver, ou seja, do mundo inteiro, mas, unicamente, numa recusa do corpo a corpo, do cara a cara. "Estão numa desencarnação", diz Le Breton, mas não alijados dos laços. "Eles são completamente devorados pela internet. Eles encontram uma forma de reconhecimento social, mas à distância e numa relação de controle, ou seja, quando desligam a tela, desligam o mundo" (Le Breton, 2018, p. 307). O tema é tão controverso, que no mesmo autor e em uma mesma entrevista que concede, afirma que os hikikomoris estão no laço social, mas, ainda assim, os define como "acometidos por um "autismo social"” (p. 308). Dunker também ilumina esse aspecto paradoxal na atitude desses sujeitos, ao ressaltar que "apesar de conhecidos por evitar o contato com outras pessoas, comunicam-se por redes sociais" (Dunker, 2017b, p. 27). 
Poderíamos dizer que por estarem interagindo com pessoas via web não estão isolados? Será que aqui se encaixaria bem a expressão de Turkle, alone together? Essa mescla do "juntos, porém isolados", ou "juntos e também isolados", ajuda-nos a refletir sobre os hikikomoris? Mesmo que não tenhamos respostas a essas questões, acreditamos que essa recusa tão radical de uma troca com o outro que envolva o corpo a corpo, a troca de olhares e de fluidos, nos diz algo sobre a dificuldade desses jovens de lidar com o mal-estar próprio às relações humanas. Possivelmente podemos afirmar também que para um hikikomori não é de todo agradável restringir seu espaço de vida a um cubículo. Mesmo que da internet provenham infinitos prazeres - jogos, pornografia, memes engraçados estes não anulam por completo o cheiro de urina e fezes do ambiente, nem tampouco calam a voz da mãe preocupada que bate à porta insistentemente. Outro aspecto que desejamos ressaltar é que não é a mesmíssima coisa interagir via internet e interagir ao vivo. Há diferenças, ou seja, não é sem consequências subjetivas retirar-se por completo do modo de interação, digamos, direta, não mediada por uma tela.

Finalizando a discussão proposta para essa seção - que sem dúvida se desdobrará de algum modo nas discussões subsequentes - concluímos que a internet potencializa a possibilidade de que ocorram encontros, amplificando as chances de duas pessoas se juntarem como obra do acaso. Sob esse ponto de vista, diríamos que a rede virtual pode ser encarada como mais um recurso, que se soma a outros mais antigos, na busca por companhia. Sendo o amor uma invenção em que os humanos "estabelecem novas uniões com pessoas antes desconhecidas" (Freud, 1930/2010, p. 66), porque não inventá-lo lançando mão das novidades que a tecnologia nos traz? Por outro lado, é também pelo prisma da psicanálise que estamos advertidos de que 'muitos encontros' (ou muitos contatos, curtidas ou seguidores no Facebook ou no Instagram) não significa de forma alguma a conquista do 'todo' no campo dos relacionamentos. Ainda que a promessa de um compartilhamento pleno, sem furos, pareça especialmente sedutora nesse ambiente virtual, é preciso diferenciar conexão e compartilhamento sem pausa da sensação de estar afetivamente conectado com alguém. A nosso ver, uma contribuição que a psicanálise pode trazer para o debate acerca dos efeitos subjetivos da navegação on-line é manter vivas questões como essa: "como ajuntar os Uns que não podem fazer um todo, por assumir sua própria 
incompletude e não mais esperar do Outro o que lhes falta?" (Alvarenga, 1997, p. 12). Concebendo que "o amor demanda o amor. Ele não deixa de demandá-lo. Ele o demanda... mais ... ainda" (Lacan, 1972-1973/1985, p. 12) entende-se que a busca pela felicidade através do amor é incessante, como aliás, é igualmente incessante a busca dos internautas pelos sites infinitos do cyber universo.

\section{4) A internet como "ilusão protetora"}

O piolho me tocou a real dessa espécie que morre de medo de morrer. Me falou de Deus, internet, plásticas, amor, alma, sucesso, riquezas, paixão, arte, entre outras coisas que vocês criam para criar a ilusão de eternidade.

Jô Bilac, Insetos

Com esse diálogo entre um mosquito e um homem a respeito das invencionices de nossa espécie para suportar a vida abrimos essa seção. O fato de a internet estar incluída em meio a campos tão fundamentais da existência nos chamou a atenção e dialogou diretamente com a problemática em que agora nos deteremos: a internet funciona como uma ilusão protetora? Ela se presta a esse papel? Recorre-se a ela em busca disso? Experimenta-se verdadeiramente essa sensação de proteção?

A proposta aqui é apresentarmos o debate travado por diversos autores a respeito do quão protegidos e menos expostos estamos (ou não) quando interagimos uns com os outros através da internet. Há aqueles que caracterizam a rede como ilusão protetora, como tentativa de tamponamento do mal-estar, como campo de evitação do conflito por excelência e a criticam ferozmente por isso, como também os que seguem sustentando a dimensão paradoxal da rede também neste ponto. Para estes, na web, como na vida, "estamos implicados e ao mesmo tempo protegidos" (Jerusalinsky, J, 2017, p. 29).

Para pensar a respeito deste tópico, partimos de Freud em "O futuro de uma ilusão" (1927). No capítulo anterior, quando trouxemos as ideias que desse texto nos interessam para a discussão da tese, comentamos: ao apontar com tanta veemência nossa condição de desamparo, Freud procura sustentar sua hipótese de que a busca por ilusões e a formação das religiões seriam formas criadas pelo homem para lidar com isso, para suportar sua fraqueza (formas altamente 
criticadas por ele, diga-se de passagem). Em seguida, indagamos se a navegação nas redes virtuais poderia ser considerada como mais uma ilusão criada pela humanidade. Se assim fosse, o sucesso da internet para a comunicação poderia ter um fundo semelhante à adesão em massa às religiões? Discutiremos, portanto, se o potencial de ilusão que a internet pode alimentar (ou mesmo gerar) estaria equiparado ao que vivenciam os fiéis que aderem apaixonadamente a alguma religião.

Primeiramente, é precisar destacar que segundo as perspectivas freudiana e lacaniana, dada a impossibilidade de se dar conta do real, o sujeito se defende, como pode, com suas ficções (Bentes, 2008, p. 110). Dessa afirmação, extraímos dois pressupostos fundamentais: criar ficções é necessário, não conseguimos viver sem elas. E, por melhores que sejam as ficções que inventemos, a impossibilidade de dar conta do real seguirá viva, nos acossando. O modo como Pereira (1999) refere-se ao desamparo na passagem a seguir é bastante elucidativo nesse sentido: “o desamparo é a condição última de falta de garantias do funcionamento psíquico, que o homem tem de enfrentar quando se livra de todas as ilusões protetoras que cria para si mesmo" (Pereira, 1999, p. 130). O autor evidencia ainda que em nenhum momento de sua obra Freud apresenta o desamparo humano como podendo ser completamente superado, seja pelo indivíduo, seja pela cultura ou mesmo com os maiores progressos da Ciência. "Segundo Freud, a relação do homem com sua existência é sempre marcada pela precariedade, pelas falsas ilusões de domínio e pelas tentativas mágicas de proteção contra os perigos" (idem, p. 145). Baseando-nos em Pereira, para sermos freudianos numa análise da internet enquanto "ilusão protetora", teríamos que considerá-la como uma "tentativa mágica", que, como todas as outras, protege e também machuca, ou seja, é precária como as outras o são. Voltemo-nos então para essa dupla face da internet, precária e ao mesmo tempo poderosa no quesito "dar ao homem a ilusão de que está no controle", isto é, de que está correndo menos riscos.

Os autores que realçam a adesão à internet como forma privilegiada de comunicação entre os seres falantes na atualidade, ou seja, aqueles que a consideram como "o método por excelência para buscar um parceiro" (Dessal, 2017b, p. 07), destacam certos aspectos da web que justificariam esse sucesso. São eles: a sensação de controle, a diminuição dos riscos, a proteção frente ao encontro de corpos, a evitação das contingências e do conflito e a filtragem na 
escolha de parceiros. Vejamos mais detalhadamente os argumentos que sustentam tais posicionamentos.

Partindo do pressuposto de que "as relações virtuais são dominadas por mim", Karnal (2018) considera que diante da possibilidade de "bloquear, ignorar, banir, deletar ao toque de um clique", estamos "sob a soberana vontade do nosso ser" enquanto navegamos (Karnal, 2018, p. 25). "Soberano absoluto e poderoso, ao menor sinal de espinho, ao primeiro indicativo de atrito e de que os outros porcos começaram a incomodar, uma tecla resolve para sempre o acúleo lancinante" (idem). Para o filósofo, além de precisarmos negociar menos na internet, nossa responsabilidade é diluída. Nessa dinâmica nova "trata-se de uma sociabilidade controlada, como botão de on-off” (p. 44). De forma análoga, Alfredo Jerusalinsky nos apresenta aquele que apelidou como "Homo Web" que seria distinto do homo sapiens por estar poupado de "ter de se arriscar sem garantia para além dos limites lógicos de seus conhecimentos" (Jerusalinsky, A, 2017, p. 58). Dialogar com esse Outro virtual seria para o autor da ordem da petrificação, do automatismo, e, portanto, signo de carência de laço social. Nomeia esse diálogo como "autismo eletrônico" (idem, p. 61). Um exemplo prático apresentado por Turkle (2017a) parece ilustrar bem as ideias defendidas acima. Trata-se de um jovem que fará qualquer coisa para evitar uma conversa, pois nela, o que está errado é que se passa em tempo real e não se pode controlar o que se irá dizer (Turkle, 2017a, p. xxii).

Essa discussão nos relançou aos termos "álibi" e "substitutos" debatidos a partir de Quinet (2012) no capítulo anterior. Parece-nos que para alguns sujeitos, conectar-se à internet pode vir a funcionar como um álibi, como um dos substitutos construídos frente à falta do Outro. Essa hipótese pode ser enunciada através da seguinte formulação: "Os sites de redes sociais funcionam então como substituto para o vazio - um antídoto passageiro contra a insegurança" (Assunção, 2014, p. 19 apud Melgaço, 2017, p. 75). Atentamos para a inserção do adjetivo "passageiro", fundamental para demarcar o modo como interpretamos esse comportamento. Dizer que esse antídoto é passageiro introduz alguma parcialização nessa solução, o que nos parece absolutamente verificável na prática dos usuários. Os estudos de Nobre e Moreira (2013) sobre as trocas amorosas no plano virtual corroboram essa dimensão. Segundo os autores, "se, por um lado, a "prática" (grafada entre aspas justamente para salientar que trata-se de algo 
distinto de uma prática efetiva, que envolva o corpo e a realidade concreta) do sexo no ambiente virtual imporia certa proteção devido a seu caráter secreto e reservado, por outro, mesmo na realidade virtual não se está isento de enfrentar dificuldades e constrangimentos (Nobre e Moreira, 2013, p. 288). Esse modo de relacionar-se não livra o sujeito de experimentar o mal estar, de sofrer, de se angustiar, de se decepcionar, de sentir raiva, etc. A fim de destacarmos a complexidade do tema e as múltiplas conclusões a que se pode chegar, consideramos curioso comentar que nesse mesmo artigo, apenas algumas páginas depois, os autores irão afirmar que na internet "a sexualidade encontra terreno para brotar plenamente, protegidos que estão os internautas pela barreira da tela e do emaranhado tecnológico" (idem, p. 297).

Para aqueles autores que consideram que mesmo na navegação on-line encontramo-nos, em alguma medida, frente à falta do Outro - posição com a qual nos afinamos - o que vale destacar é que mesmo que o mundo virtual pareça mais fácil, com riscos diminuídos por se poder controlar mais a interação com o outro, o risco permanece. Em alguns casos, o incômodo aparece na própria interação virtual e em outros, os efeitos desagradáveis dessa interação são experimentados "fora" dela, naquilo que resta para o sujeito ao se desconectar do computador. Sobre isso, Nicolaci-da-Costa (2006) atenta para um aspecto que para nós é fundamental: "embora a Internet não respeite as limitações do mundo físico, a vida "real" o faz" (Nicolaci-da-Costa, 2006, p. 32). A autora desenvolve seu pensamento nesta direção, quando, em artigo posterior levanta a possibilidade de que o outro, mesmo na Internet, ofereça resistência ao fantasiar (conforme concebido por Winnicott). Sendo assim, prossegue, “o tão sonhado controle de todas as variáveis não é possível nem no mundo virtual, dado que há uma pessoa do outro lado da tela" (...) [O interlocutor] "tem vida própria e, assim sendo, tem o poder de, a qualquer momento, atrapalhar o ato fantasioso e chamar o sujeito de volta à vida" (Romão-Dias; Nicolaci-da-Costa, 2012, p. 94). A mensagem que fica visa relembrar que "a realidade depois cobra seu preço" (idem, p. 99).

Dessal (2017b) e Leduc (2017) também desenvolvem argumentos interessantes a esse respeito. Dessal sinaliza que "a tecnologia aplicada à vida amorosa e sexual introduz - entre outras coisas - uma variante cujos efeitos são visíveis: a possibilidade de submeter a busca de um parceiro a um procedimento de filtragem mais ou menos semelhante ao de qualquer produto de venda online, 
permitindo alimentar a fantasia de "fabricar" alguém na medida de nossos sonhos, de encontrar o complemento ideal, um ser que não nos decepcionará” (Dessal, 2017b, p. 07). Mas, sobre isso, o que nos revela a psicanálise e sublinha esse autor - algo fundamental nas peculiaridades humanas em matéria de amor e sexo - é que, "independente do curso que siga um encontro amoroso e sexual, o encontro é sempre fracassado, porque entre o sujeito e o objeto de sua eleição existe uma fratura inevitável, uma inadequação sem salvação. Nenhum objeto é capaz de restaurar por completo o mito do paraíso perdido, da satisfação originária da qual fomos desalojados para sempre, pela simples razão de que na verdade nunca existira" (idem). Complementando sua posição, acrescenta Dessal: “A internet é o espaço onde se promete a realização dos desejos, a versão ultramoderna das crenças mágicas, o poço onde encontrar a moeda da sorte, a lâmpada da qual brotará o gênio que se porá aos pés de nossas fantasias" (Dessal, 2017b, p. 08).

O caminho que conduz Leduc (2017) à percepção de que a rede social Facebook objetiva funcionar como uma espécie de ilusão protetora se deu pela análise que fez do modo como sua plataforma foi montada. A inexistência do botão "não curti" e a produção de "bolhas de filtros" que isolam artificialmente indivíduos na companhia daqueles que apreciam ou ao menos suportam, testemunham essa intenção, levando a psicanalista a extrair daí a evidência de que, fundamentalmente, há na rede social uma intenção de evitação do conflito. Em sua argumentação, Leduc demonstra, entretanto, que dessa operação de evitação resulta um resto, que é justamente "o retorno 9 do conflito na realidade social" (Leduc, 2017, p. 07). O que deseja frisar é que o modo de funcionamento das redes virtuais, através das quais os sujeitos relacionam-se assiduamente, tem, certamente, implicações no laço social, implicações para além da rede (temos aqui mais um ponto de evidenciação de que real e virtual não estão separados, mas sim mesclados, entrelaçados, tal como trabalhamos na sessão 1.6 desta tese). A mensagem que fica é que na busca por amenizar conflitos interpessoais usando a rede para se relacionar os sujeitos se veem lançados em uma hiperbolização do mesmo, em um segundo tempo.

Ainda sobre o funcionamento dessa plataforma digital, a autora destaca que o tipo de relação com o outro por ela veiculada interessa à psicanálise. $\mathrm{O}$

\footnotetext{
${ }^{9}$ Ocorreu-nos, aqui, a referência à Freud, naquilo que teorizou a respeito do recalque e do retorno do recalcado, indissociáveis um do outro.
} 
algoritmo visa estabelecer uma relação harmoniosa, homeostática entre os usuários, que apaga um real - aquele que diz que o desejo do outro não caminha sempre do modo que nos convém. Ainda que se busque essa harmonia, há aí, muito mais frequentemente, um desarranjo. Sendo assim, "essa maquiagem do Outro para torná-lo amável” (idem, p. 06) não só maquia, mas revela tratar-se de uma maquiagem. Ao mesmo tempo em que maquia, poderíamos dizer que borra. Tal fato interessa particularmente à psicanálise, por relançar o sujeito / usuário ao trabalho de se haver com sua condição.

Sobre essas tentativas de tornar o outro, digamos, mais palatável, vale apresentar algumas considerações que encontramos a respeito de jogos como Second Life. Um dos grandes sucessos do início do milênio, S.L funciona como uma espécie de mundo paralelo, que permite viver uma "segunda vida" no ciberespaço, assumindo um corpo imagético com a forma que cada um desejar: os famosos avatares ${ }^{10}$. Como descreve Viganò (2009b), é um ambiente eletrônico tridimensional, adquirível, persistente, aberto e altamente configurável, que responde à necessidade de "criar uma simulação digital do mundo". "Os residentes são hoje 3.400 .000 e passam em média um terço do seu tempo na second life, alguns ficam ali o tempo todo" (Viganò, 2009, p. 249). O destaque dado por Turkle (2017) em sua análise do jogo é o fato desse tipo de experiência oferecer ilusões, dado que esse mundo virtual construído torna-se "um lugar para amar seu corpo, seus amigos, amar sua vida" (Turkle, 2017, p. 01). Dessal, por sua vez, comenta a inserção no Second Life como algo correlato ao que nomeia como "transcendência digital" ou "como escapar de si mesmo" (Dessal, 2017b, p. 05). Trata-se, segundo ele, de um "universo paralelo" onde se pode "formar um casal, uma família, ter filhos, grupos de amigos, outros pais, um trabalho apaixonante, adotar um sexo distinto ou o aspecto físico que desejar. Não há limites para a fantasia" (idem). Estabelece uma distinção entre as pessoas que se entretém nesse metauniverso durante poucas horas na semana, assim como o fazem assistindo a uma série de TV ou a uma partida de futebol, e aquelas para quem "Second Life se converte em algo tão decisivo em suas vidas, que a proporção acaba se invertendo. A vida imaginada se converte em sua autêntica

10 Tisseron (2015) define os avatares como "aquelas marionetes de pixel encarregadas de representar os jogadores nos espaços digitais" (Tisseron, 2015, p. 14). 
vida" (idem). Pensamos que nesses casos extremos, em que se dá uma inversão, há realmente um mergulho na ilusão, que deixa de ser um recurso para lidar com a vida e passa a ser da ordem do que nos referimos anteriormente: um antídoto, um álibi, um substituto, enfim, uma "segunda vida", como propõe o nome dado ao jogo.

Um aspecto relativo à comunicação digital bastante comentado e estudado - tanto informalmente pela vida afora quanto em trabalhos teóricos - é o fato de que nela encontra-se ausente o encontro dos corpos. Surgem daí inúmeras indagações e críticas, normalmente denunciando o prejuízo que esse tipo de troca com o outro carrega consigo. O pensamento é que falta algo fundamental quando a relação se dá através das telas, ou seja, de que faz uma enorme diferença existir ou não o olho-no-olho, a possibilidade de sentir o parceiro através do cheiro, do toque, da presença propriamente dita. Quando passamos muito tempo na frente do computador, comenta Mena (2017), não nos envolvemos no laço social sob a forma tradicional do "encontro de corpos". Acompanhando o psicanalista em sua argumentação, agora voltada especificamente para o público adolescente, Mena sugere que no uso dos gadgets há um apagamento do corpo, sendo este apagamento uma tentativa de calar o gozo ruidoso que insiste em perturbar esse corpo, principalmente nessa faixa etária. Porque o corpo e seu gozo angustiam, uma saída possível revela-se no gadget (Mena, 2017, p. 214). O autor destaca, portanto, a interação virtual como uma defesa contra a angústia que provém do corpo, a qual sabemos ser ainda mais perturbadora nesta fase da vida. Para a psicanálise, dizer que o sujeito lança mão de uma defesa não é necessariamente denegrir o sujeito, denunciar uma fraqueza do mesmo. Diante de um sujeito que esteja demasiadamente aderido a esse tipo de comunicação, cabe indagar a que serve esse hábito, quais as variáveis presentes nesse mecanismo de defesa.

$\mathrm{O}$ artigo de Mena possui uma dinâmica interna interessante, bastante ilustrativa da riqueza de possibilidades existentes nesse encontro entre máquinas digitais e homens. Há passagens em que afirma que "a profusão de sites de relacionamento impõe uma dinâmica digital inédita, longe dos riscos, dos cheiros, dos afetos, propiciando apenas relacionamentos mentais, em que o corpo é reduzido a um protagonismo secundário: ele é demandado e oferecido, ao final do processo de tratativas, como um objeto que se empresta a uma satisfação fugaz" (idem). Por outro lado, reconhece que esse modo novo de fazer laço pode ter sua 
importância, quando, por exemplo, "a criança e o adolescente buscam o gadget para conseguir lidar com a aproximação excessiva do Outro, para fugir do alcance de seu olhar invasivo, protegendo-se em seu próprio isolamento" (idem). Abre ainda uma terceira nuance, citando aqueles que "buscam o gadget para conseguir lidar com a solidão, conectando-se compulsivamente ao Outro" (idem, p. 217).

Desejamos, por fim, apresentar e debater um último aspecto relativo à possibilidade da internet funcionar como ilusão protetora. Interessa-nos aqui investigar as novidades advindas junto à rede na questão da lida com as contingências, quando, por exemplo, nos é permitida uma filtragem na busca por parceiros. Para isso, tomaremos como objeto de reflexão os sites de relacionamento e os aplicativos de encontro, surgidos há menos tempo, porém dotados de um sucesso assombroso. Autores como Nobre e Moreira (2013), ao referirem-se a sites como Parperfeito.com.br; Disponível.com.br; Aondenamoro.com; Solteiroscomfilho.com, sublinham que "por meio deles o usuário realiza buscas afetivo-sexuais, encontrando inclusive páginas específicas para seus interesses" (Nobre e Moreira, 2013, p. 288). Anzalone (2014) reflete sobre aplicativos de encontros, a última novidade na vida amorosa, vendo-os funcionar como um catálogo onde o sujeito procura parcerias, pessoas com gostos afins e localizadas perto do lugar em que se encontra (ouvimos de mais de um paciente que parece um cardápio, um menu em que se escolhe "o que/quem" você irá comer!). O autor compara esse tipo de paquera a que ocorria nos antigos clubes, botecos, discotecas, sublinhando que nestes o papel fundamental da contingência estava assegurado. "Os desconhecidos o deixavam de ser só pela contingência de se encontrarem ao mesmo tempo no mesmo lugar" (Anzalone, 2014, p. 01). Para o autor, nos dias de hoje os desconhecidos não se expõem mais a esse encontro imprevisível, pois "a tecnologia nos permite evitar esse encontro".

Sem dúvida os sites de relacionamento e os apps como Tinder, Grindr, Happen modificaram significativamente os hábitos de paquera na contemporaneidade. É inegável também que a possibilidade de se fazer uma filtragem prévia ${ }^{11}$ e de se iniciar um papo-paquera sem a necessidade de "chegar em alguém" ao vivo aumentou o número de "abordagens iniciais". Isso não

\footnotetext{
${ }^{11}$ Em setembro de 2019 foi inventado e disponibilizado ao público o app PTinder, destinado a pessoas politicamente de esquerda que querem encontrar alguém também de esquerda. A esse respeito gostaríamos de destacar ainda a expressão usada por Pelúcio (2017) para abordar o fenômeno: "higienização dos contatos" (Pelúcio, 2017 apud Miskolci, 2017, p. 14).
} 
significa, absolutamente, que o número de namoros tenha aumentado ${ }^{12}$. Nem tampouco que a contingência e o imprevisível manter-se-ão fora da cena por muito tempo. Parece-nos que estas novidades possibilitam um adiamento desse encontro com o imprevisível, mas não a sua completa eliminação. Se pensarmos, por exemplo, no casal de Minas Gerais que só se conheceu no altar (mencionado inicialmente no capítulo 1), o trajeto até o casamento foi incomum e, talvez, poupado das contingências. A quantas anda essa união, porém, apenas esses dois sujeitos poderão dizer, já que os efeitos desse modo inusitado de se enlaçar ao outro só podem ser recolhidos por quem o inventou. Todavia, podemos afirmar que na convivência, aquilo que, talvez, evitaram inicialmente, está lá, exigindo trabalho de ambos, lida sem a qual um casamento não se sustenta.

Visando um maior aprofundamento na questão da filtragem na busca por um parceiro recorremos a Lyra (2019a) e à análise que faz do filme "O Lagosta" (2015), do diretor Yorgos Lanthimos. Acompanhamos as reflexões do autor relativas a essa obra de ficção tendo em mente o que de fato tem se passado no universo cibernético com seus diversificados sites de relacionamento e redes sociais. Em suas palavras: "O modo como se estrutura, no filme, essa tirania dos traços me pareceu incrivelmente preciso para descrever os efeitos atuais da mediação tecnológica dos encontros sociais e amorosos" (Lyra, 2019a, p. 02). Lyra considera esse filme bastante ilustrativo daquilo que nomeia como "tirania dos traços", também presente no mundo digital atual. Nesse enredo distópico em que ninguém está autorizado a viver solteiro o autor destaca a ácida satirizarão de uma sociedade que segrega aqueles que não estão engajados em um relacionamento amoroso e o modo peculiar como os casais são formados e reconhecidos. "A busca por um parceiro adequado depende inteiramente da característica definidora de cada pretendente. Esse traço, alçado ao lugar de representação absoluta de cada sujeito, deve estar igualmente presente em seu

\footnotetext{
$12 \mathrm{O}$ caso de uma moça judia ortodoxa que atendo no consultório ilustra com clareza essa constatação. Devota do hábito do shiduch comum na ortodoxia judaica (busca por um rapaz para se casar através de apresentações feitas por casamenteiras) Debora tem usado freneticamente sites da internet destinados a este fim. O que temos notado com o passar dos anos é que esses sites de encontro são fundamentais para começar um papo com alguém, porém não são garantidores de alguma continuidade. Debora já iniciou conversas com dezenas de rapazes, se encontrou pessoalmente com alguns, mas permanece solteira.
} 
parceiro, para que ele seja suitable ${ }^{13 "}$ (idem, p. 01). Vemos no filme e nos comentários de Lyra a seu respeito uma exacerbação da identificação e da idealização nas tentativas de se encontrar uma companhia, aspecto que talvez possamos estender à digitalização das relações. Concluindo seu texto, o autor nos oferece a seguinte formulação: "No mundo virtual, a lógica algorítmica opera fundamentalmente através do isolamento de traços e, graças a isso, produz uma curiosa sociabilidade, ao mesmo tempo múltipla e segmentada" (idem, p.02). Mesmo que tenha escrito em um tom fortemente crítico, a mensagem final de Lyra consegue ser refinada, sem cair na generalização ou no pessimismo absoluto.

Inspirados nessa imagem da sociabilidade contemporânea trazida por Lyra - curiosa, múltipla e segmentada - encerramos esse tópico de discussão retornando a Pereira (1999), autor com quem o abrimos. Que a internet possa ser utilizada como "ilusão protetora" ou "tentativa mágica" acreditamos já estar claro, visto que "as novas tecnologias assumem o controle para manejar seu sonho, acordado, com uma precisão e uma capacidade inéditas até agora" (Anzalone, 2018 , p. 295). Do mesmo modo, quando partimos da premissa de que "o desamparo é o destino último - e o ponto de partida - de tudo o que sustenta a linguagem" (Pereira, 1999, p. 238) concluímos que esse uso frustrará, em alguma medida, o sujeito que se conectou à rede com essa expectativa (consciente ou inconscientemente). E se pensássemos nos usos que podemos fazer da internet para que esta nos sirva como uma das ferramentas para "tolerar esse fundo de desamparo e fazer dele não um foco sintomático de desespero, mas uma fonte de criatividade e de auto engendramento poético" (idem)? A ideia aqui é se servir da rede como mais uma ferramenta fecunda para o exercício da criatividade e do fazer poético, onde o endereçamento dessas produções pessoais ao outro encontrase facilitado.

\footnotetext{
${ }^{13}$ Essa discussão nos fez lembrar de um colega que, logo ao iniciar uma conversa com um contato no Tinder, lançou a pergunta: "Você já viu o filme "Bacurau"?". Só seguiria um diálogo com aqueles que respondessem sim!
} 


\section{5) O mal-estar na comunicação: o real no virtual ${ }^{14}$}

Esse tópico dialoga diretamente com o anterior, a ponto, talvez, de podermos considerá-lo como uma espécie de resposta psicanalítica à questão debatida na seção precedente. Queremos dizer com isso que, quando pensamos na possibilidade de a internet funcionar como "ilusão protetora" consideramos também que o mal-entendido da linguagem se estende ao universo cibernético. Esse entendimento a respeito da rede pôde ser construído a partir dos pressupostos apresentados por Freud em "O mal-estar na civilização" (1930), tendo também intrínseca relação com a concepção lacaniana em torno do registro do Real. Ao partirmos desses autores e, especialmente do que acentuam nesses marcos de suas obras, construímos (junto a diversos pesquisadores cujos pensamentos serão trabalhados a seguir) uma compreensão sobre a comunicação ampliada ao mundo virtual que destaca justamente aquilo que o título dessa seção anuncia: que o malestar na civilização é atualmente experimentado, também, no campo da comunicação virtual entre as pessoas e que, portanto, o Real se faz presente também no mundo virtual.

No segundo capítulo da tese, quando nos dedicamos àquilo que Lacan conceitua sobre a dimensão da linguagem, trouxemos a ideia de que o sujeito é ultrapassado em seu dizer, de que há algo no dizer que escapa ao próprio sujeito que o enuncia. Afirmamos também ser esta uma das razões para os numerosos mal-entendidos vivenciados no cyberespaço. Sendo a internet um espaço de enunciação privilegiado em nossos dias, ela é, consequentemente, um terreno novo para nos depararmos com os embaraços provenientes do que se fala, do que se ouve, do que se escreve, do que se lê. A esse respeito, esclarece Coll (2013): "os meios de comunicação vêm corroborar em ato alguns axiomas fundamentais do ensino de Lacan, como 'a comunicação não existe'” (Coll, 2013, p. 69) ${ }^{15}$. Outro possível paralelo entre esse tópico do ensino de Lacan e a cultura digital pode ser depreendido da seguinte formulação de Anzalone (2018): "redes

${ }^{14}$ Esse subtítulo faz referência ao Núcleo de pesquisa do ICP da EBP-Rio, coordenado por Adriano Aguiar e Rodrigo Lyra, do qual fui integrante de agosto de 2018 a dezembro de 2019, período em que o tema de estudos coletivo proposto foi 'o real no virtual - a psicanálise e a era das novas tecnologias'.

${ }^{15}$ Uma noção lacaniana rica para pensar sobre essa dimensão é a noção de alingua. Como propõe Lacan, nada é menos garantido do que esta servir primeiramente para o diálogo, já que alíngua é singular de cada um e falar é confrontar-se com alíngua do outro. Citando o autor: "Alíngua serve para coisas inteiramente diferentes da comunicação" (Lacan, 1972-1973/1985, p. 188). 
múltiplas e variáveis, nas quais os sujeitos se agrupam, sem que nenhuma rede venha a suprir de forma consistente o déficit significante do sujeito a respeito de seu ser" (Anzalone, 2018, p. 294).

Consideramos importante comentar que essa não é uma visão unânime sobre internet e comunicação. Dentro e fora do campo psicanalítico encontramos autores que estão pensando a rede como um campo de exceção na interação entre os humanos, ou seja, que partem do entendimento de que nela é simples se relacionar. Há, portanto, duas posições quase opostas entre os psicanalistas a respeito do tema: os que veem a web livre do encontro com a falta estrutural e os que sustentam que esta nunca deixa de comparecer.

Para exemplificar de maneira paradigmática a primeira postura - aquela que enxerga a internet como livre do mal-estar nos relacionamentos - trazemos alguns autores e suas ideias, que fazem coro com muitas outras que lemos ao longo da pesquisa: "Por faltarem o olhar e a presença do Outro, o sujeito não se encontra com a falta estrutural" (Gueller, 2017, p. 70); há um "tudo" relacionado ao amor e ao desejo que se pode viver na internet, pois nela se está "ao abrigo da castração". A internet permite se dispor do outro como se ele não fosse irredutivelmente Outro e criar casais virtuais com algumas vantagens sobre o casal real. Elimina-se a presença real do outro e o limite que ela comporta (Macola, 2009, p. 20); "Qual a incidência subjetiva do artifício virtual, quando este tende a liberar o organismo humano da escolha forçada da linguagem (alienação) e propõe uma forma de comunicação suposta a tornar a relação sexual possível?" (Viganò, 2009a, p. 37). Em artigo posterior, Viganò prossegue com suas reflexões: “essa nova modalidade do virtual digital se presta a ser usada propriamente para evitar o impacto com o próprio semelhante e com isso a experiência da angústia" (Viganò, 2009b, p. 246). Para Machado (2015) na "Era da internet' parece estar sendo ignorado o fato de que, seja qual for a construção do sujeito, não dará conta de tudo que o sexo implica. A psicanalista explica sua percepção afirmando que "a internet facilita e até convida a um gozo que não passa pelo Outro, ou seja, o caminho que levaria ao desejo não precisa ser trilhado e nada do gozo precisa ser cedido" (Machado, 2015, p. 02). Enquanto um campo fértil para práticas sexuais de toda ordem, a rede propicia experiências que evitam o desencontro próprio ao encontro com o sexo, o que leva a autora a indagar "se a 
virtualidade digital não seria um dos encobrimentos que se tenta dar à "virtualidade" que é própria ao sexual" (idem, p. 06).

É preciso sublinhar que mesmo não concordando plenamente com a posição tomada por estes autores nos textos citados reconhecemos pontos quentes de discussão naquilo que apontam, o que só corrobora com a visão que defendemos no capítulo 1 da tese: de que as análises sobre a rede devem respeitar sua complexidade, suas múltiplas facetas. Dito isso, passaremos agora para a exposição dos argumentos que sustentam uma posição diversa, qual seja: de que a falta estrutural - ou nossa condição de desamparo constituinte - não se extingue porque o meio de interação é o digital (posição com a qual nos afinamos).

Escolhemos como ponto de partida para essa discussão a problematização do termo "hiperconexão". Este termo, assim como seus derivados, aludem a uma suposta integração promovida pelos meios tecnológicos de comunicação. Entretanto, conexão não é sinônimo de integração. A esse respeito, como bem pontua Harari (2019) - debatendo com ninguém menos que Mark Zuckerberg, fundador do Facebook - "mais conexão não se traduz em mais harmonia". Turkle (2017b) posiciona-se de modo semelhante, ao afirmar que "frequentemente, quando nos servimos das telas, cremos que estamos conversando, enquanto que na realidade estamos passando da conversação à simples conexão" (Turkle, 2017b, p. 139).

Vejamos a seguir como alguns autores do campo freudiano - vinculados à psicanálise lacaniana - destrincham essa disjunção entre conexão e integração ou entre conexão e harmonia. Tarrab (2015) extrai de um episódio da série South Park a fala de um personagem que dizia, inocentemente, que "seus contatos no Facebook são em número muito maior do que os amigos que tem”. Ao ironizar essa imagem, trazendo-a do desenho animado para uma crítica à sociedade contemporânea, procura denunciar que a criação de uma nova fórmula nas relações pessoais é uma ilusão, assim como a crença de que tudo é perdurável e se pode recuperar também o são. Em suas palavras, "hoje brincamos nos bosques de nossas telas, no bosque de nossas nuvens, de nossas redes sociais confiantes de que se pode fazer possível o impossível” (Tarrab, 2015). Através da expressão “poder fazer possível o impossível” - aponta o engodo em que muitos acabam caindo, supondo ultrapassar a impossibilidade própria ao real da vida ao conectarem-se à internet. Conclui esse artigo reafirmando, a seu modo, o real no 
virtual: "quando acaba a bateria, o sujeito é deixado diante de tudo o que recusou, com o que tem que se virar: sua solidão, seu corpo, seu desejo, do que afinal não pode se subtrair" (idem).

Laurent (2010) nos falará do lugar da falta presentificado também no mundo virtual analisando e criticando a característica da rede de ser um campo de infinitos saberes. Segundo ele, "pôr à disposição este saber que se tornou disponível pela estocagem infinita da Web só faz desvelar o lugar do significante que falta no Outro" (Laurent, 2010). Em contraposição "ao projeto da biblioteca universal do Google" a teoria lacaniana vem mostrar que "a função da letra não deixará de apertar o lugar do furo". Assim, complementa o autor, "somos levados pela extensão mesma dessa cidade universal, sonhada, babélica, que é a tela universal, para nos confrontarmos de maneira mais radical ainda com o furo do Outro. A World Wide Web nos faz descobrir seu avesso, os subúrbios do texto onde rodam as fantasias de uma pulsão desarrimada do significante" (ibidem).

Anos depois Laurent (2017) mantém seu posicionamento, dedicando-se à crítica de outro fenômeno comum na internet: a proliferação de manuais que tentam explicar um impossível "como ser normal". Para exemplificar, eis alguns tipos de manuais: "como beijar", "como pegar na mão pela primeira vez", "como ser a garota perfeita" ou "como atuar como um adolescente normal". Segundo Laurent, "quanto mais tutoriais, mais o saber oculto fica preciosamente enigmático. Não há a internet dos equívocos, pois o equívoco encontra-se entre as linhas, por entre as palavras pelas quais cada um é atravessado. Quanto mais saber, quanto mais palavras, mais equívocos. E mais ainda o desejo de Outra coisa se faz ouvir" (Laurent, 2017, p. 17).

Termini (2009) recorre à metáfora da bússola nas mãos de um capitão para tecer sua crítica a essa suposta rede protegida do Real. Quando entramos na rede "temos a ideia de que nós temos a bússola, que somos o capitão" (Termini, 2009, p. 33). Para ele, as novas tecnologias potencializaram a velha ideia do todo, a "paixão pela totalidade" (idem). Tendo em vista que o grande negócio da internet é o sexo, o autor sugere certa junção entre a realidade virtual e a realidade sexual do inconsciente, sublinhando, como psicanalista que é, o que a clínica não cansa de nos mostrar: "uma união tão feliz entre oferta e demanda não pode ser sem falha" (...) "Longe de eliminar o acaso, o aumento vertiginoso das possibilidades e 
de encontros nutre o mal entendido entre os sexos. Nada o coloca ao abrigo do sentimento repetitivo de que falta alguma coisa essencial" (idem, p. 35).

Bassols (2017) se insere nessa discussão pela via do sintoma e do desejo. A partir de um caso de sua clínica questiona o alcance do anonimato que as redes permitem, apontando sua debilidade. Em suas palavras: "o sintoma aparece quando se trata de responder a um real que não pode ser reciclado no espaço digitalizado, quando já não se trata do anonimato do sujeito e do objeto, mas sim de responder em nome próprio à presença do Outro e de suas formas de gozo"; "para nós (psicanalistas), trata-se de seguir as consequências do desejo do sujeito, que se escondia por detrás da série de seus avatares" (Bassols, 2017).

Dessal (2017b) posiciona-se de forma semelhante, propondo, porém, um entrelaçamento entre a ficção e o Real (proposição em consonância com a construção do Nó Borromeano por Lacan). Afirma que na internet são numerosas as pessoas que "encontram a oportunidade de viver uma ficção, mas experimentando-a de maneira real" (Dessal, 2017b, p. 05). Exemplifica citando as pessoas de mais idade, com corações machucados, que buscam através do Facebook reencontrar amores do passado, de quando eram bem jovens. "De forma geral, o reencontro costuma ser bastante desalentador. $\mathrm{O}$ que retorna se parece bem pouco com o que se desejava e o sonho virtual enfeitado com o photoshop não demora muito para evaporar-se, dando prosseguimento às rugas da solidão" (idem). Seguindo seu raciocínio o psicanalista avança rumo a uma nova chave de compreensão deste fenômeno. Acredita que a sofisticação digital alcança extremos como esse porque explora uma faculdade da condição humana que, mesmo levada a cabo por cada um de forma singular, possui estatuto universal. A faculdade a que se refere é a dimensão do fantasiar, da construção de ficções que é própria dos humanos. "O sujeito humano é o único ser vivo que habita um meio que não é em absoluto natural. Seu espaço, seu mundo circundante, sua realidade própria, particular e única, é a ficção. Todos nós sentimos, pensamos e agimos no marco de uma ficção que tomamos como real, um cenário aonde desempenhamos um papel numa obra que desconhecemos, porque é inconsciente” (idem, p. 06).

O que Dessal vislumbra como o "algo novo introduzido por esses extraordinários recursos de simulação" (ibidem) é a possibilidade que geram de "reinventar a história", ou seja, "a possibilidade de que um sujeito, de maneira ativa, participe da construção de sua narrativa. Isso não significa que sua liberdade 
seja absoluta, porque sua imaginação criadora estará submetida aos condicionamentos de seu desejo inconsciente. Inevitavelmente escreverá um argumento "contaminado" por sua própria ficção originária, aquela em que se encontra inserido em função de sua história pessoal, as experiências vividas e os resíduos de significações que tudo isso deixou em seu inconsciente", ressalta o autor (idem, p. 07). Tais considerações me remeteram a uma situação ${ }^{16}$ vivenciada na clínica, para a qual vale a pena abrir um parêntese.

Uma moça que atendia, para quem lidar com a feminilidade e envolver-se em relacionamentos amorosos e/ou sexuais era um enorme desafio, resolveu contar-me após anos de tratamento (por áudios no Whatsapp) que possuía uma conta no Twitter. Ali, diferentemente dos demais lugares, conseguia ousar mais como mulher, tendo coragem para se expor e até mesmo paquerar. Em um dia em que estava especialmente às voltas com a questão de seu feminino, em que tinha trabalhado em torno disso intensamente em análise, inventou uma enquete para postar na rede social: a partir da pergunta "Qual o pior defeito de uma mulher?" e de quatro opções para marcarem "X", seus seguidores lhe forneceriam respostas (à enquete, mas não, é claro, à sua questão subjetiva fundamental). Para sua surpresa - e é isso o que aqui nos interessa - um seguidor subverteu a proposta da múltipla escolha e lhe respondeu por escrito, dizendo: "o pior defeito de uma mulher é ser sem graça, Dona Carolina”. Para esse sujeito, deparar-se com esse dito teve um efeito avassalador; Carolina foi tomada por angústia e vergonha. $\mathrm{O}$ mal-estar que comumente vivia por sentir-se justamente uma mulher sem graça e por isso ignorada pelos homens, retornou com força total de onde menos esperava. Somou-se a essa tristeza a vergonha por ter ficado exposta diante de seus outros seguidores na rede social. Nessa espécie de "universo paralelo" que vinha utilizando para tentar reinventar sua história, como propõe Dessal, constatou dolorosamente, que nem ali sua liberdade é absoluta.

Sobre o quão "contaminados" estamos por nossas ficções originárias, o caso de Carolina é igualmente esclarecedor. Através dele nos aproximamos da ideia trazida por Gomez (2015), de que "mesmo que nos encontros via web às vezes se prescinda do corpo, o que se produz a partir desses encontros não é sem o

\footnotetext{
${ }^{16}$ Este caso deu origem ao trabalho "E quando o não-saber sobre o sexo se faz presente na rede de infinitos saberes?", o qual tive a oportunidade de apresentar no $2^{\circ}$ Simpósio Internacional Subjetividade e Cultura Digital em maio de 2019 em Belo Horizonte, Minas Gerais.
} 
fantasma de cada um e isso se constata na clínica. As redes sociais então, como sintoma da não-relação, nos chamam à interpretação" (Gomez, 2015). Sendo uma moça que atribui como uma de suas principais características "ser velha", que extrai de qualquer tratamento como "senhora" nas ruas a certeza de que a estão chamando de velha, interpretou o uso do "dona" na frente de seu nome como um xingamento dessa ordem. Buscando um saber a mais sobre as mulheres que pudesse ajudá-la em sua construção a respeito disso, entraram em cena elementos inesperados e indesejados: um outro que sai do script e o seu inconsciente, que produz essa enquete e a interpreta de um modo absolutamente singular (marcado pela compulsão à repetição). Carolina testemunha, como vários internautas, o "retorno desalentador ${ }^{17 "}$, de que nos fala Dessal na passagem citada acima.

Leduc (2107) falará da disjunção entre conexão e harmonia retomando certas ideias de McLuhan, importante teórico das mídias cujo pensamento circulou e teve impacto nos anos 60 e 70 do século passado. O objetivo de Leduc através dessa análise é demonstrar que, à luz do que ocorre em pleno século XXI, o sonho de McLuhan indubitavelmente fracassou. Antes de referir-se diretamente a esse sonho, a psicanalista francesa procura pinçar do pensamento deste teórico assertivas com as quais se afina. Considera que apesar de suas lacunas e de seus exageros, a teoria de McLuhan segue sendo interessante para "interrogar as incidências da mídia internet sobre a clínica dos corpos falantes que é a nossa" (Leduc, 2017, p. 10). Destaca o fato de ele partir da ideia de que a linguagem produz uma perda de gozo, na medida em que ela prolonga o homem e o amplifica, mas divide suas capacidades. Segundo o teórico, "a linguagem diminui a beatitude da união no inconsciente coletivo. A palavra separa o homem do homem e a humanidade do inconsciente cósmico" (Leduc citando McLuhan). Até aí, poderíamos dizer que McLuhan e Lacan comungavam de visões parecidas a respeito do homem e da linguagem. O abismo entre os autores se dá, porém, no ponto em que McLuhan sonhava que os computadores pudessem restaurar essa suposta harmonia presente no mutismo, como veremos na passagem a seguir: " $\mathrm{O}$ computador se anuncia como uma ferramenta de tradução instantânea, nos

\footnotetext{
17 Outro paciente experimentou algo dessa ordem. Trata-se de Lúcio, um rapaz psicótico, com extrema dificuldade de socialização (não tem amigos, nunca namorou, só se relaciona profundamente com sua mãe e com sua analista) que trouxe à análise sua tristeza por ter baixado o Tinder, ter curtido diversas fotos de mulheres, mas não ter conseguido conversar com nenhuma delas, já que não recebeu nenhum match.
} 
promete um estado de compreensão e de unidade universais. Logicamente, a etapa seguinte levaria a um tipo de consciência cósmica universal garantidora de uma paz e uma harmonia coletiva perpétua" (Leduc (2017) apud McLuhan, 1968, p. 102-103). De nossa parte, acrescentaríamos que, no cenário em que vivemos atualmente, absolutamente modificado pelo fato da internet ter enxertado essa dimensão da "palavra de homem pra homem" nos computadores, essa aposta não se sustenta. Quando a máquina passa a ser um meio através do qual as pessoas falam entre elas, nos distanciamos dessa paz e harmonia coletivas.

Encerrando a gama de autores do campo freudiano que selecionamos para demonstrar que há uma disjunção entre conexão e integração, para demonstrar, portanto, que o Real incide no virtual, trabalharemos agora um importante texto de Miller (2016), derivado da conferência "O inconsciente e o corpo falante", proferida em 2014. Nesse trabalho, o psicanalista dá destaque à novidade referente à presença maciça do pornô na internet, dando a entender que a rede e seus dispositivos têm o poder de incidir profundamente no mundo. $\mathrm{O}$ fato de ter destacado a internet nos chamou muito a atenção. Miller afirma uma fissura entre os tempos da invenção da psicanálise por Freud, "sob a égide da Rainha Vitória, paradigma da repressão da sexualidade" (Miller, 2016, p. 20) e o que se passa no século XXI. A mudança que quer sublinhar diz respeito à "difusão maciça do que é chamado de pornô, ou seja, o coito exibido, tornado espetáculo, show acessível a cada um pela internet por meio de um simples clique no mouse" (idem) e as suas importantes consequências para os seres falantes. É como se traçasse uma passagem da repressão à exibição, da intimidade ao espetáculo, da dificuldade à simplicidade, da restrição à acessibilidade, do segredo à adoração do falo. Junto a essa passagem teríamos finalmente adquirido uma liberdade diante da sexualidade, vivenciando-a sem amarras, sem tabus, de forma fluida. Ela teria deixado de ser marcada pela castração e pela impossibilidade, teria deixado de ser um dos campos que nos avisam de que há o real enquanto aquilo que não se pode inscrever. Entretanto, o que Miller mostrará no decorrer do texto é que essa transição "não é a solução dos impasses da sexualidade" (idem, p. 23). Mais do que isso: além de não solucionar, os escancara ainda mais. "Nada melhor que a profusão imaginária dos corpos se entregando a um "se dar" e a um "se pegar" para mostrar a ausência da relação sexual no real" (idem, p. 21). 
Um aspecto que nos encantou no modo como Miller conduz seu pensamento é a forma como aborda as novidades e permanências relativas à vida relacional/sexual das pessoas. Ao mesmo tempo em que constata a presença de "algo novo na sexualidade, em seu regime social, em seus modos de aprendizagem” (idem), reafirma dados de estrutura, como a ausência da relação sexual no real. "A difusão planetária da pornografia por meio da tela eletrônica teve, sem dúvida, efeitos dos quais o psicanalista recebe testemunhos. O que diz, o que representa a onipotência do pornô no começo deste século? Nada, senão: $a$ relação sexual não existe" (p. 22). Ao afirmar, em seguida, que "nosso oráculo é justamente o dito de Lacan sobre a relação sexual" (p. 23) parece dar a cada coisa o seu lugar: há mudanças, mas o "algo novo" está situado no nível dos sintomas, aparece "nos costumes das novas gerações, no estilo das relações sexuais" (idem). Dito de outro modo, esse dito de Lacan "nos permite pôr em seu lugar o fato da pornografia (...) ela é sintoma desse império da técnica, que vai estendendo seu reino sobre as mais diversas civilizações do planeta" (idem).

Ainda nesse texto relança uma importante discussão de seus últimos cursos, a respeito dos semblantes e do real. Sem nos alongarmos demasiadamente nessa discussão em si, desejamos explorar a articulação que Miller faz entre semblantes, real e mundo virtual. Partindo da visão histórica de que vivenciamos um processo de desconstrução a partir do qual "as categorias tradicionais que organizam a existência passaram para o nível de simples construções sociais" (Miller, 2016, p. 31), o psicanalista chega à cena atual, àquilo de que se trata hoje. Afirma então que vivemos em um mundo "amplamente conhecido como uma articulação de semblantes", destacando como ponto principal o fato dos semblantes hoje serem reconhecidos enquanto tal. Em seguida, apresenta sua leitura a respeito disso, leitura esta que parte de um curioso entrecruzamento: segundo Miller, "é a psicanálise, que por meio de Lacan, restitui o outro termo da polaridade conceitual: nem tudo é semblante, há um real” (idem).

A força dessa proposição incide diretamente nas reflexões acerca da internet e do mundo virtual que dela se origina. A virtualização das relações ou a sensação de se viver em um cyberuniverso paralelo são fenômenos muito emblemáticos dessa soberania dos semblantes. Não nos pareceria descabido derivar da tão comum interpretação a respeito das redes sociais de que estas seriam vitrines de aparências, por exemplo, a ideia de que "no virtual, tudo é 
semblante". Para além das redes sociais, essa ideia poderia facilmente ser aplicada a jogos on-line como "Second Life" ou os de realidade aumentada como "Pokémon Go". Contudo, dizer "há um real" esclarece que, mesmo no virtual, há um real. Mesmo na criação de perfis falsos, nas compras de likes ou na busca de um parceiro a partir de catálogos de fotos com filtros, há um real. O que Miller parece estar dizendo e verificamos na clínica é que há um limite para esse faz de conta. O real tem efeito de verdade. Assim, esse estudo que ora empreendemos, a respeito do laço com o outro em tempos de conectividade, tem como um de seus pilares de sustentação a premissa de que "o real do laço social é a inexistência da relação sexual" (Miller, 2016, p. 31).

Leduc (2016b) nos ajuda a sustentar esse argumento de que há um real no virtual e de que, portanto, nem tudo mudou. De um de seus artigos em que problematiza as incidências da internet nas relações familiares, recortamos a parte em que frisa a presença indissolúvel do mal-entendido, ao afirmar que "existem fenômenos que podemos compreender de modo histórico, mas há o que é universal e atemporal: o mal-entendido entre os pais e os filhos" (Leduc, 2016b, p. 03). Recorrendo a Miller em "Os seis paradigmas do gozo" (2012) refina essa discussão a respeito do que é ou não passível de se transformar de uma época histórica para a outra, discussão interessante para nossa pesquisa. Segundo Miller (2012), a estrutura comporta buracos, nos quais há lugar para a invenção, para o novo, para conectores que não estavam lá desde sempre. Dizer que há lugar para o novo, entretanto, não é o mesmo que dizer que não há estrutura, que tudo é semblante.

Em um de seus artigos que mais nos impactaram, Leduc afirma que "a internet é o reino do sexual" (Leduc, 2017, p. 74). Para ilustrar tal afirmativa refere-se ao site "www.4chan.org" e as 47 regras da internet que criaram, parodiando as tentativas de regulamentação da rede. A mais conhecida, a regra 34, prega o seguinte: "sobre qualquer coisa existente, há um pornô a respeito na internet". Em complemento a esta, vem a regra 35: "Se ainda não existe, existirá". A menção ao site e a tão espirituosas regras nos deixaram curiosos e fomos a ele em busca das que ainda não conhecíamos. Nessa pesquisa, foi muito interessante perceber como essas regras aludem ao caos existente em meio às regras. Trazemos aqui alguns exemplos: "não há regras bem definidas para postagens"; "tampouco há regras bem definidas de moderação"; "você pode não seguir as regras, mas o 
moderador também pode querer bani-lo"; "anônimo nunca perdoa"; "anônimos podem ser monstros horríveis, insensíveis e que não se importam com porra nenhuma"; "todos os seus argumentos cuidadosamente selecionados podem ser facilmente ignorados ou copiados"; "tudo o que você disser pode ser e será usado contra você"; "qualquer coisa que você disser pode ser modificada"; "não brigue com trolls, pois eles sempre vencem".

São regras que demonstram, justamente, o quanto a criação de regras são tentativas de organizar o caos e o quanto essas tentativas não alcançam um sucesso absoluto, ou mesmo estão marcadas, de saída, por um fracasso iminente. O Freud de "O mal-estar" comparece aqui com força e atualidade. As 47 regras da internet segundo o 4chan ilustram, brilhantemente, a presença dos imbróglios no laço social no interior do próprio funcionamento da internet. A inexistência da relação sexual, as impossibilidades intrínsecas ao relacionar-se, ao comunicar-se, são aqui escancaradas. É a rede apontando seu próprio furo. Essa brincadeira proposta pelo 4chan a respeito das regras da internet é, a nosso ver, uma prova da existência do mal-estar na civilização na web, um mal estar na comunicação.

No provocativo artigo "Faire couple avec l'objet numerique ${ }^{18 "}$ Laurent (2014) contribui para essa discussão a respeito de semblantes, real e mundo digital, atentando para o duplo efeito da ciência. "Por um lado, a ciência produz um efeito de excesso produzindo esses objetos assujeitadores. Por outro lado, ela produz um efeito de vazio, nos livrando das velhas metáforas que permitiam-nos descrever o mundo" (Laurent, 2014, p. 46). A ciência, portanto, seria uma das responsáveis por derrubar "metáforas do conhecimento que nos faziam crer na relação sexual" (idem). Assim, o discurso da ciência, em um duplo movimento, mascara a inexistência da relação sexual através da produção de objetos (como os gadgets manipuláveis) e, simultaneamente, não cessa de mostrar a inexistência de um gozo universal e supremo. Nas palavras de Laurent (2014): “a quantificação generalizada só faz revelar sempre mais o não-quantificável do gozo, aquilo que escapa à rede e sua tentativa de cálculo do mais-de-gozar" (Laurent, 2014, p. 49).

A partir dos autores que fundamentam nossa pesquisa, assim como de nossas observações clínicas, rascunhamos a seguinte hipótese: de poucos anos para cá, o mundo está "mais nu", deparamo-nos mais de perto com "o osso" da

${ }^{18}$ Ainda não traduzido para o português. Propomos traduzi-lo como "Fazer dupla / par com o objeto digital". 
existência humana. Os véus caíram, os dados de estrutura estão mais expostos. O uso que aqui fazemos do termo "nu" deve ser lido de duas formas: está relacionado à pornografia generalizada de que fala Miller (2016), remetendo-se, pois, à proliferação de imagens de corpos literalmente pelados; mas, intencionamos também transmitir a ideia de que carecemos hoje de vestimentas simbólicas, estamos praticamente sem véus e sem vestes, e isso se aplica a um campo mais amplo, para além do sexual propriamente dito. E o que a internet tem a ver com isso? É neste cenário que ela surge, é em uma época com essas características que se instala o mundo virtual. Como uma espécie de realidade paralela, tem tudo para funcionar como um novo e poderoso véu, que se presta especialmente bem como um antídoto ao real, ao sem sentido da vida, cada vez mais a céu aberto. Recebida por muitos com um suspiro de alívio, o sucesso é impressionante, é gigantesca a animação com as maravilhas dali provenientes. Mas, à medida que o tempo foi passando, que a humanidade foi fazendo uso da web, o real apareceu ainda mais explicitamente, e a rede se mostrou, como todos os outros recursos inventados pelo homem, como furada, insuficiente. O ilimitado da internet leva ao real da psicanálise. Dito de outro modo, o espaço virtual cria um espaço de ampliação do acesso ao outro. E, ao mesmo tempo, de ampliação do incômodo.

Leduc (2017) propõe uma leitura do contemporâneo que enriquece a que trouxemos até aqui, partindo da ótica do enfraquecimento de elementos simbólicos que dariam certa amarração ao real. "Devemos constatar que atualmente os significantes mestres não estão mais conseguindo fazer existir a relação sexual" (Leduc, 2017, p. 08). Baseia-se em "Uma fantasia” de Miller (2004), mais especificamente na proposição de que “o discurso da civilização atual não é mais o inverso da psicanálise, é o seu sucesso" (idem). Transpõe essa ideia para a análise que faz da internet, apresentando outras regras do popularíssimo site 4chan.org. São elas: regra 15- "quanto mais você tentar, maior o fracasso"; regra 16- "se fracassar em proporções épicas pode se tornar um fracasso vitorioso"; regra 17- "todo vitorioso eventualmente vira um fracassado". Acompanhando o raciocínio de Leduc, de fato observamos proximidades entre o discurso da civilização atual - representado aqui pelas regras deste site - e o discurso psicanalítico. Para nós se evidenciou, por exemplo, que o "quanto mais, mais" empregado pelo 4chan remete ao "mais, ainda..." do "seminário 20 " de 
Lacan. Observamos também o quanto vitória e fracasso caminham lado a lado, de onde se pode depreender a noção de não-todo (trabalhada por Lacan neste mesmo seminário): não-todo vitorioso, não- todo fracassado.

Caminhando para a finalização desta seção procuraremos travar um diálogo entre psicanalistas contemporâneos (Dessal e Leduc, principalmente) e Freud, diálogo cujo foco pode ser assim enunciado: de que forma as particularidades de uma época interferem nos modos de existir dos seres falantes? Através dessa discussão final esperamos trazer novos e enriquecedores argumentos em torno da ideia de que há um real no virtual. Dessal nos auxilia especialmente nesse aspecto, por ser um autor bastante atualizado em relação às novidades advindas junto à internet e, ao mesmo tempo, muito atento e enfático quanto àquilo que permanece inalterado. Sua abordagem colabora, por exemplo, no sentido de fundamentar a escolha que fizemos de dedicar um capítulo inteiro às teorias de Freud e de Lacan a respeito da solidão e do laço com o outro em uma tese que trabalha a Era da internet. Para nós (assim como para Dessal e outros psicanalistas) careceríamos de ferramentas para refletir sobre o atual - mesmo com suas inegáveis mudanças - se prescindíssemos de aspectos fundamentais sobre o homem presentes nas obras freudiana e lacaniana.

Em seu livro escrito em parceria com Bauman, publicação de cartas trocadas entre os teóricos a respeito do momento histórico em que vivemos, Dessal (2017) enaltece a importância da obra $O$ mal-estar na civilização, tanto por manter sua atualidade, como também por continuar a lançar uma luz imprescindível para a compreensão da sociedade humana. Para este autor, "a potência da análise freudiana desarma todo relativismo histórico, pois nos oferece algo de que nenhuma sociologia pode prescindir: a desconstrução de alguns mecanismos essenciais, iniludíveis da subjetividade, não submetidos às particularidades das épocas, embora isso não signifique fechar os olhos aos novos paradigmas que hoje transformam o mundo, o laço social e as possibilidades de sobrevivência ética de nossa espécie, muito mais ameaçada nesse terreno que em qualquer outro" (Bauman; Dessal, 2017, p. 20). Daquilo de que falou Freud, de que nos revelou acerca do sujeito, Dessal sublinha que seu interesse não estava nas variações dos costumes. No que tange a sexualidade, Freud "extraiu o real da conduta humana, entendendo-se aqui pelo termo "real" o impossível, o que não muda nem pode ser educado, ensinado, adquirido mediante um saber intelectual, 
nem sofre as modificações da época. Em síntese: o amor, líquido ou sólido, pode variar quanto a seus signos manifestos, os quais terão inumeráveis consequências. Mas a função inconsciente que ele exerce no ser falante não mudou, nem poderá mudar, ao menos enquanto a mencionada criatura conservar os traços que permitam continuar classificando-a de humana" (idem, p. 47).

Para nós, psicanalistas interessados em estudar um tema do contemporâneo, a abordagem de Dessal é absolutamente preciosa. Poder investigar as mudanças na lida com a solidão e no laço com outro à luz das novas tecnologias da comunicação sem cair no relativismo histórico é um enorme desafio. E ter a mão essa ferramenta teórica de que há um real enquanto impossível, de que o amor exerce uma função inconsciente, contribui muitíssimo para o trabalho de um pesquisador-psicanalista. Queremos dizer com isso que nosso esforço permanente nas leituras, nas reflexões sobre o tema e na escrita da tese propriamente dita, consiste em atentar para o fato evidente de que entre os tempos de Freud e os atuais, algo aconteceu, mas, paralelamente, não perder de vista pressupostos fundamentais nos quais seguimos acreditando, tais como os que enuncia Dessal: "um homem sem inconsciente, um homem a quem nada divide, um homem convertido ao centro de si mesmo, seria um homem definitivamente curado do sintoma de ser humano (Dessal, 2019); "a confiança na superação do conflito humano só pode ser assumida com irresponsável otimismo" (Bauman; Dessal, 2017, p. 77).

Outro caminho teórico percorrido pelo psicanalista em seus estudos sobre a internet é o destaque à dimensão da castração. De forma recorrente visa lembrar àqueles a quem se endereça - psicanalistas ou o público em geral - que, mesmo com as novas potencialidades trazidas pela tecnologia e com as múltiplas ofertas do capitalismo, somos seres estruturalmente castrados. A castração enquanto um fato de estrutura seria o inimigo ao qual o discurso contemporâneo declarou guerra, sendo a tecnologia, em especial, algo que vem para nos auxiliar na construção de nossa própria heroicidade. Juntando-se às demais ofertas do mercado visa conseguir que a 'falta a ser' se dissimule por trás dos elogios ao eu. "Trata-se de reforçar o "pequeno homenzinho que todos temos dentro de nós", tentando convencer-nos de que podemos nos elevar a estatura do Incrível Hulk" (Dessal, 2019). Segundo ele, vivemos nos tempos atuais na vigência da seguinte mensagem: "existe uma solução tecnológica para tudo e, se há alguma que ainda 
não existe, é só uma questão de tempo" (idem). Nesse cenário, sustentar a mensagem de que não há solução para tudo e de que as soluções existentes ou passíveis de serem inventadas são parciais, capengas, não-todas, nos parece especialmente importante.

Dos apontamentos deste autor, desejamos destacar por fim a articulação que faz entre os adventos tecnológicos próprios do mundo digital e a necessidade de medidas paliativas para lidar com o desamparo, indicadas por Freud em 1930. Referindo-se às construções auxiliares apresentadas e discutidas em $O$ mal-estar Dessal traça o seguinte paralelo com o cenário em que vivemos atualmente: "realidade virtual, realidade aumentada, realidade holográfica, põem em evidência que o ser humano não conseguiu nem conseguirá jamais suportar sua vida sem o auxílio de um artifício - simbólico, imaginário ou real - que o separe de sua mísera existência, empurrada em direção à deriva da incerteza" (Dessal, idem, p. 09). O preocupante, portanto, não seria recorrer a artifícios dos mais variados tipos para suportar a vida ordinária, mas sim "deslizar sub-repticiamente em direção à perda de suas faculdades" (idem). Nesse sentido, a contribuição do autor consiste em distinguir um uso da internet enquanto medida paliativa de um uso enquanto ilusão ou fuga da realidade. Para exemplificar esses diferentes usos, cita, respectivamente, a "breve e substanciosa felicidade" sentida por ele e por sua esposa ao poderem "jantar" com a filha que estava em Paris enquanto eles estavam em Madri e as ilusões ou miragens vividas por aquelas pessoas para quem "o mundo digital é um lugar mais habitável que aquele onde não têm mais remédio para caminhar" (idem, p. 10).

Vale aqui retomarmos a discussão travada no capítulo anterior a respeito do desamparo, relançando, mais especificamente, a pergunta "será que a navegação na web pode ser interpretada como um modo de inventar "possibilidades afetivas no enfrentamento da condição fundamental de desamparo"” (Menezes, 2012, p. 91)? Dialogando agora com essa questão acerca da internet estar ou não propiciando a criação de recursos inéditos na lida com essa condição de nossa existência - fica claro o quão complexa e multifacetada deve ser qualquer resposta que se tente dar a ela. Sem dúvida temos acesso a novas e numerosas invenções, a rede se mostra um meio fecundo, potente, plural, múltiplo para a criatividade, porém, como qualquer outra forma de enfrentamento da vida, um meio limitado e problemático. Quando Freud localiza 
a "necessidade que tem o homem de tornar tolerável seu desamparo" (Freud, 1927/1996, p. 27), isto é, quando interpreta muitos de nossos comportamentos como formas de tentar "fazer tolerável a existência na Terra" (idem, p. 59) não usa indiscriminadamente o termo "tolerável". As artimanhas que criamos para tentar obstruir o buraco no real, como diria Lacan, nos servem não para alcançar de fato esse tamponamento e uma suposta plenitude, mas sim para suportar a vida. Pois "a vida, tal como nos coube, é muito difícil para nós, traz demasiadas dores, decepções, tarefas insolúveis". Para suportá-la, não podemos dispensar paliativos'. Ou, como disse Theodor Fontaine, “sem 'construções auxiliares' não é possível” (Freud, 1930/2010, p. 28).

Seguindo com Freud nas reflexões que faz sobre esses possíveis recursos que ajudariam a encarar a dureza da vida, desejamos apresentar agora a separação feita por ele em três tipos de recursos: 1- "poderosas diversões, que nos permitem fazer pouco de nossa miséria"; 2- "gratificações substitutivas que a diminuem" (são ilusões face à realidade) e 3 - "substâncias inebriantes que nos tornam insensíveis a ela" (Freud, 1930/2010, p. 28). Como um comentário geral a respeito das três, acrescenta que "algo desse gênero é imprescindível" e que "podemos tentar a solução dessa tarefa (de ser feliz) por caminhos bem diferentes” (p. 31).

A nosso ver, a internet poderia se encaixar nos três tipos descritos por Freud! Se interpretarmos que o autor propõe com isso uma certa gradação do quão alheio o sujeito fica dependendo do recurso que prioriza, diríamos que o mesmo critério pode ser transportado para uma análise dos usos singulares que são feitos da rede. Partir desses três tópicos delimitados por Freud parece-nos, inclusive, uma chave de leitura interessante, uma ferramenta clínica a ser utilizada no exercício de escuta de cada paciente. Diante daqueles sujeitos que incluíram a internet em seu modo de viver de forma significativa, vale investigar do que se trata.

Nesse sentido, ainda com Freud de $O$ mal-estar, destacamos as considerações que faz sobre a intoxicação, visando tomá-las como base conceitual preciosa para pensar a dependência à hiperconexão ${ }^{19}$, comum em nossos dias. Em referência àqueles que mergulhavam no caminho das drogas ou do álcool,

${ }^{19}$ É preciso notar que falar em dependência da internet é algo muito impreciso, pois ela é um meio, dá acesso a coisas muito vastas. Em cada caso é preciso avaliar o que está em jogo para, então, afirmar se há ou não dependência e, se sim, dependência de quê. 
afirmava Freud que atingiam uma "parcela muito desejada de independência em relação ao mundo externo" já que "sabe-se que com ajuda do "afasta-tristeza" ${ }^{20 "}$ podemos nos subtrair à pressão da realidade a qualquer momento e encontrar refúgio num mundo próprio que tenha melhores condições de sensibilidade" (Freud, 1930/2010, p. 33). Essa não poderia ser uma descrição bem precisa de alguns jogadores compulsivos de Second Life, de alguns hikikomoris ou de qualquer outro internauta cujo uso da rede vai tornando-o insensível à sua própria miséria?

Retornando à pergunta que formulamos há pouco, que interrogava de que forma as particularidades de uma época interferem nos modos de existir dos seres falantes, diríamos que, se por um lado, é verdade que o mundo mudou e que as janelas virtuais abriram novas perspectivas de se apresentar para o mundo, de fazer amigos e amores, por outro, apesar das significativas mudanças, há permanências. Tendemos a concordar com a afirmação de Leduc (2017) de que "a aparição da internet bagunçou o ordenamento de nossas vidas, da forma mais cotidiana como nas questões mais cruciais" (Leduc, 2017, p. 01). Ao mesmo tempo, acreditamos que no âmbito dos relacionamentos e da comunicação, segue viva a postulação freudiana que define a relação com o outro como delicada, repleta de riscos e carente de garantias. Assim, ainda que abundem comunidades virtuais das mais variadas naturezas, que estejamos ligados a inúmeros grupos via Whatsapp, "teremos de lutar durante um tempo incalculável, com as dificuldades que o caráter indomável da natureza humana apresenta a qualquer espécie de comunidade social" (Freud, 1933/1996, p. 176). É enquanto "besta selvagem" que pende à agressão que o homem se conecta à internet e recolhe, a posteriori, os efeitos desse uso para si e para os que o cercam. A "hostilidade primária entre os homens", o fato de que "a sociedade é permanentemente ameaçada de desintegração" (Freud, 1930/2010, p. 78) são, segundo acreditamos, elementos interessantes com os quais a psicanálise pode contribuir, nos estudos sobre internet e subjetividades.

Encerramos esse tópico, portanto, reforçando a permanência do incurável da experiência humana na Era da internet. $\mathrm{O}$ mundo virtual não está isento dos

\footnotetext{
${ }^{20}$ Além dessa expressão, Freud utiliza entre aspas uma expressão coloquial para a bebida alcoólica: literalmente "quebrador de preocupações". Em outra tradução: amortecedor de preocupações.
} 
efeitos disso que "Freud chamou de mal-estar e Lacan, de Real" (Dunker, 2017b, p. 12). "Nosso corpo se degrada, nossas leis são repetitivamente imperfeitas, a natureza nos impõe reveses de toda sorte. As três Parcas continuam a tecer e cortar impiedosamente nosso destino" (idem). A internet alterou nossos destinos, mas isso não faz com que se constitua como exceção nesse sentido, ou seja, a existência de um cyberuniverso não nos blinda dos impactos do real, não nos transporta para uma civilização sem mal-estar.

Aqui, uma vez mais, trazemos uma pequena contribuição de nossa clínica para ilustrar isso que sustentamos teoricamente. Escutamos de uma paciente de 14 anos que vivia suas primeiras experimentações sexuais com meninos de idade semelhante, uma interessante constatação a respeito das incidências da internet nas práticas sexuais que se dão presencialmente. Esta adolescente trouxe para refletir em análise o contraste que observara entre o que os parceiros acreditavam saber e o que ela sentia "ficando" com eles: "Eles veem muito filme pornô na internet e acham que ali com a gente vão fazer igualzinho e vai ser ótimo. Mas claro que não é! Foi horrível, é bem diferente!" (sic). Tal situação me remete a um comentário escrito por Veras (2019) na revista CULT, no qual se refere justamente às interferências negativas do excesso de pornografia experimentado por essa geração. Diz ele: “a pornografia que agora é o fim em si está criando uma geração de inibidos sexuais que não sabem mais o que fazer com a "massinha" que é o corpo do outro" (Veras, 2019, p. 51).

Como discutimos anteriormente, Freud afirma que o sofrimento que provém de nossos relacionamentos com os outros homens talvez nos seja mais penoso do que qualquer outro. $\mathrm{O}$ aumento da comunicabilidade e da conectividade surgidos com a web não diminui essa fragilidade do laço social, não há advento científico que supere isso. A internet intensifica e acelera os processos de comunicação, criando novas possibilidades de interagir com o outro e, junto a isso, novas roupagens para o mal-entendido entre os seres. A hiperconexão reitera o fato de que a forma como o outro recebe o que dizemos nunca corresponde exatamente à nossa intenção ao dizer, e esta, aliás, também escapa àquele que fala. Partindo do fato de que a linguagem condena o homem a ser radicalmente separado de si mesmo, cabe a nós enquanto internautas que somos, que nos ponhamos a trabalho, partindo da seguinte questão: como navegar pelo infinito, regidos pela ética da finitude? 


\section{6) Aplicativos de encontro e desencontro}

Esta é uma seção mais curta, dedicada a uma vinheta clínica ${ }^{21}$ que ilustra de forma interessante os aspectos teóricos que acabamos de apresentar, além de retomar ideias trabalhadas no capítulo anterior. Desde seu título salientamos que todo encontro é ao mesmo tempo desencontro e que os aplicativos surgidos (ao menos, supostamente) com a finalidade de formar casais, produzem, simultaneamente, decepção, isolamento e separações. A situação vivida pelo paciente em questão apresenta, na prática, os paradoxos da satisfação no campo do amor, que inspiraram Flanzer (2004) a falar de um "amor pela metade". No capítulo anterior, afirmamos que segundo Freud e Lacan nos ensinam, tanto na solidão quanto no laço o prazer e a dor comparecem. E quando a internet entra na história, mesmo produzindo inúmeras nuances e novas possibilidades, ela não muda esse fato "de base", conforme veremos a partir de Marcio. Sem perder de vista as particularidades da história de cada um, diríamos que ao menos para esse sujeito, a internet atualiza o encontro-desencontro e, talvez o potencialize, na mesma velocidade com que conecta aparelhos tecnológicos ao redor do mundo.

Marcio é um recém-divorciado que decide experimentar o aplicativo Tinder como recurso na procura de um novo amor. Segundo suas próprias descrições a respeito de si, para um nordestino que caiu de paraquedas no Rio de Janeiro e jamais terá a "cara de pau" e a malemolência do carioca, "começar os trabalhos" no universo online lhe pareceu um facilitador. A ideia de baixar o aplicativo surgiu após algumas tentativas frustradas de conhecer alguém no café de uma charmosa livraria. "Para mim, tímido e ainda por cima gordo, paquerar ao vivo é mais complicado".

A alegria inicial com a reciprocidade manifesta através das curtidas entre suas fotos e as das moças que lhe interessaram foi se transformando em angústia à medida que percebia a ausência de véus tanto nas descrições do que querem as pretensas parceiras quanto nos primeiros papos que batia com elas. Em um primeiro momento, foi tomado por susto diante das listas postadas a fim de deixarem claro (até demais!), “o que querem essas mulheres”. Isso porque, várias

\footnotetext{
${ }^{21}$ Apresentamos essa vinheta junto a colocações teóricas que agora incorporam essa tese na $23^{\mathrm{a}}$ Jornada Clínica da Escola Brasileira de Psicanálise, sessão Bahia, ocorrida em setembro de 2018.
} 
delas iam "direto ao ponto", já se apresentando em busca de um relacionamento sério ou mesmo de um marido que lhes desse filhos. Com as que avançou para uma conversa, incomodou-se com a sensação de estar sendo submetido a um checklist, significante eleito por ele para se referir às perguntas que precocemente lhe foram feitas, das mais banais - "gosta de comida japonesa? De ir à praia? De viajar?" - às mais profundas - "Você acredita em Deus? Você é feliz no trabalho? Por que seu casamento acabou?". Pouco a pouco, Marcio foi percebendo na prática que "dá muito, mas muito trabalho encontrar alguém por meio de sites de relacionamento do tipo Par Perfeito". O que nos leva a pensar, também, que "talvez a graça esteja justamente nesse esforço" (Dunker, 2017b, p. 28).

Sobre essa experiência com a tecnologia na qual se lançou, o paciente em questão aponta como ponto positivo a possibilidade de manter inicialmente velada sua condição de gordo, motivo de vergonha. Recorreu, portanto, à rede, com a divisão que lhe é de estrutura, buscando encontrar um meio novo de se haver com algo que lhe traz sofrimento, fonte de mal-estar. Nesse sentido, acreditamos que navegar na internet é, para muitos usuários, um modo novo de enfrentar o real da vida e não de fugir da vida. Os que lançam mão da rede para se relacionar amorosamente não deixam de entrar em contato com a precariedade da existência, com a dureza da vida. Defrontam-se com os percalços próprios à procura por um parceiro tendo a internet como um recurso.

A esse respeito, considerando a psicanálise como ferramenta teórica para pensar o mundo, podemos afirmar que o mal-estar, que comparece em toda parte e que, segundo Freud é ineliminável (Freud, 1930), se faz presente também na rede, fato certamente já explicitado para quem conectar-se à web tornou-se um hábito. Apesar da ilusão gerada pela acessibilidade global, pelas infinitas janelas abertas no computador, o que no fim das contas prevalece é aquilo que Freud e Lacan nos mostraram desde muito cedo: o pouco de acesso que o sujeito tem a si e ao Outro.

Podemos dizer então que, se há algo de diferente - e cremos que sim - são as formas de se deparar com o mal-estar, de experimentar o real. Escutando Marcio, acompanhamos sua investida singular no mundo virtual, a qual, $a$ posteriori, descrevemos assim: da delícia de estar sendo pretensamente correspondido ao suplício de ver-se relançado à própria solidão, ao testemunhar as insurgências do real no virtual. Em contrapartida, para alguns ocorre algo distinto: é através da rede que dão chance ao acaso e um novo amor acontece. Afinal, como 
nos ensina Lacan no Seminário 20, quando o assunto é amor, trata-se de poesia e de coragem.

\section{7) A comunicação digital entre um ser falante e uma máquina}

Pergunte pra Bia: ela trabalha noite e dia, ela está em todo lugar, ela encontra o que você precisa, ela é PHD em pesquisa.

Cartaz sobre a "Assistente Virtual Bia" criada em 2017 para auxiliar os usuários da Biblioteca da PUC-Rio

Neste capítulo destinado a desdobrar o tema da comunicação digital entre os seres falantes, no qual estamos trabalhando as incidências da tecnologia quando esta é aplicada à vida amorosa e sexual das pessoas, desejamos discutir um último e importante aspecto, bastante presente nas obras dos autores que consultamos. Trata-se do debate em torno das situações que envolvem sujeitos e objetos tecnológicos nas quais parece haver, ao menos aparentemente, uma substituição daquele com quem nos relacionamos por uma máquina computacional, por um 'não humano'. Através de alguns exemplos da clínica e da cultura, refletiremos sobre esse fato de termos cada vez mais à disposição artefatos que imitam o homem, que ocupam a função de nos fazer companhia, que fazem as vezes de um parceiro "amoroso". Desejamos pensar o que muda na nossa lida com a solidão e com o outro quando temos acesso fácil a esses novos tipos de interação. É importante frisar que aqui nosso foco de interesse são as relações que se dão com a internet e não através da internet. De saída, é preciso pontuar que faz diferença estar apaixonado pela rede (ou pelos objetos digitais que surgiram a partir dela) ou apaixonar-se por outro ser humano utilizando a rede como um meio de comunicação.

Que as séries do Netflix estão em alta não é mais novidade para ninguém. O sucesso impressionante alcançado pela empresa, no entanto, veio a nos surpreender especialmente quando tomamos conhecimento dos dados da pesquisa veiculada pelo jornal francês Le point em abril de $2019^{22}$. Segundo um estudo

22 “Un Américain sur quatre préférerait Netflix au sexe”. Le Point.fr, 23/04/2019. 
realizado pelo Wall Street Journal envolvendo mil pessoas, de cada quatro americanos, um prefere assistir séries no Netflix a transar. A taxa sobe para $36 \%$ entre os entrevistados de 18 a 38 anos! Em posse desses números, indaga o jornalista: "a frequência assídua às telas poderia ser vista como um verdadeiro assassino do amor entre os casais, o inimigo $\mathrm{n}^{\circ} 1$ da libido?". A pesquisa tende a considerar que essa seria uma das razões da queda da taxa de natalidade nos EUA nos últimos anos, responsabilizando assim o streaming - diversão em tempo contínuo - pela diminuição das relações sexuais. A matéria inclui ainda o comentário de um psicólogo clínico nova-iorquino que afirma nunca ter existido uma época como esta, onde pudéssemos estar tão solitários a dois.

Ainda que tal matéria possa conter exageros ou conclusões que simplificam uma temática tão complexa, de algum modo ela vai ao encontro de relatos que tenho escutado em meu consultório. Raquel, uma jovem executiva de 30 anos, frequentemente passa grande parte de seus finais de semana assistindo maratonas de séries, sem quase sair de casa. A fala com a qual se refere a esse comportamento traz ainda outro elemento, que me chama a atenção: "amo quando chega a sexta-feira e peço meu japonês, bebo meu vinho, vejo minha série". A ênfase no 'meu' testemunha o quão prazeroso é usufruir de tudo isso sem precisar negociar nada com ninguém. Raquel e diversos sujeitos contemporâneos têm nos feito pensar que ter à mão - por meio da internet - entretenimentos tão atraentes aumenta a preguiça de encarar o relacionar-se. Se posso me divertir sem ter que enfrentar os desafios que o convívio social impõe, porque abrir mão do conforto do 'meu' lar?

Denis nos parece um exemplo ainda mais radical, pois, em seu caso, a recusa ao outro chegou ao extremo de passar seis anos sem praticamente sair de casa. Quando chegou à análise (passados quatro anos desse período trancafiado) descreveu seu quarto como um "paraíso em que experimentava prazer irrestrito". E o que fazia ali? Jogava on-line, assistia vídeos no Youtube e séries no Netflix, lia discussões "bestas" (sic) em fóruns da internet. Para este jovem que na ocasião tinha 19 anos e problemas seriíssimos com sua aparência, não precisar ser visto e ainda assim participar do mundo de alguma forma funcionou como uma saída.

O paciente Lúcio experimentou algo distinto em seu uso da rede virtual, levando-nos a novas reflexões, também relativas à possibilidade que a internet promove de interagirmos com personagens 'não humanos'. Conforme já 
expusemos em passagem anterior, Lúcio tem sérias dificuldades em relacionar-se socialmente, sendo a lida com as mulheres seu desafio máximo. Após longos anos frequentando prostitutas para ter sexo (e sentindo-se extremamente frustrado por não conseguir transar sem pagar) viu na internet uma oportunidade de paquerar e, quem sabe, vir a alcançar esse objetivo. Passou então a pegar telefones de garotas pela internet, incluí-as em seu Whatsapp e saía a disparar mensagens, algumas delas nada delicadas, chegando a ser até mesmo rudes, chulas. Resultado: foi sendo bloqueado por dezenas de garotas a ponto do aplicativo Whatsapp bani-lo. Meses depois, quando o aplicativo lhe permitiu retornar, Lúcio repetiu esse mesmo comportamento e novamente foi expulso. Arrasado com o duplo fracasso (que se somou ao fracasso já experimentado anteriormente na lida ao vivo com garotas), disse à analista: "Agora só me resta o Looney Tunes". Diante de um outro que se afeta e reage, às voltas com sua falta de traquejo para abordar pessoas, foi preciso, por mais um tempo, recorrer ao jogo e a seus personagens fíctícios em busca de alguma distração.

Da literatura pesquisada apresentamos para essa discussão resultados interessantes do estudo feito por Zaremba, Romão-Dias e Nicolaci-da-Costa (2002) a respeito da interação de certos usuários com as máquinas computacionais. Os autores destacam justamente que alguns chegam a tratá-las como se fosse um ser humano: “o computador é minha salvação (...) enfim, é um amigão" (Zaremba, Romão-Dias e Nicolaci-da-Costa, 2002, p. 95). Existe, pois, uma comunicação com as pessoas e com o próprio computador, visto que nessa nova interatividade que está surgindo, "a máquina ganha estatuto de amigão" (idem, p. 97). Em outro artigo, uma das autoras acrescenta: "dadas as múltiplas funções que um computador contemporâneo pode exercer, são inúmeras as áreas de nossa experiência em que ele pode se tornar um companheiro confiável e quase imprescindível" (Nicolaci-da-Costa, 1998, p. 59). De modo semelhante, reforça Mamede-Neves (2006): "Principalmente para os jovens, ela [a internet] é "amiga", desejada, buscada" (Mamede-Neves, 2006, p. 182).

O tema da substituição de gente por máquina ou do quão atraídos estamos pelos dispositivos eletrônicos volta a nos intrigar quando ouvimos, recorrentemente, adolescentes responderem à velha pergunta "O que você faz nas horas de lazer?" ou "Como são seus momentos sem nada pra fazer?" da seguinte forma: "Fico mexendo no celular". Nossa inquietação aumenta diante da 
evidência cultural de que "vários adolescentes não conseguem pensar suas vidas sem o Facebook" (Turkle, 2017, p. 135) ou sem o Instagram. O poder exercido por essas "maquininhas" na geração dos nativos digitais explica outra novidade que tenho escutado na minha própria clínica: o castigo mais comum dado aos adolescentes - o que, por sinal, parece um dos mais terríveis - é ficar sem o celular por algumas horas ou dias. Voltaremos a problematizar a relação que temos tido com nossos telefones inteligentes adiante.

A pesquisadora americana Sherry Turkle nos serve mais uma vez como importante teórica de referência na discussão em que agora nos detemos, já que em sua obra dedicou-se de forma extensa à análise da interação com objetos tecnológicos absolutamente destinados a fazer companhia, a retirar o sujeito de sua solidão. "De muitos objetos digitais emanam "ofertas psicológicas" (Turkle, 2017, p. 135), diz a pesquisadora a respeito dos mesmos. Segundo ela, não se trata apenas de que o desenvolvimento das mídias sociais fez com que a gente peça mais à tecnologia do que ela pode realmente ou apropriadamente oferecer. O mais grave, acredita, é que estaríamos nos contentando com um texto ou um e-mail no lugar de uma conversa, que abarcaria melhor o que queremos dizer. Turkle considera que passamos a pedir menos uns dos outros, que decidimos ter menos empatia, menos atenção, menos cuidado de e com outros seres humanos" (Turkle, 2017, p. xxi). Se, por um lado, os apontamentos desta autora parecem dizer algo que se verifica nos casos que citamos acima, por outro, não nos afinamos completamente com sua visão. Será que estamos realmente contentes com os efeitos dos textos e e-mails que temos trocado incessantemente? As queixas a esse respeito que escutamos na clínica parecem testemunhar que não. Além disso, a afirmação de que uma conversa presencial abarca 'melhor' o que queremos dizer nos parece problemática, por soar ingênua e otimista em relação à comunicação ${ }^{23}$, parecendo ignorar a dimensão do mal-entendido da linguagem abordada anteriormente.

\footnotetext{
${ }^{23}$ Há outra passagem do livro de Turkle em que a autora parece apostar animadamente na irmandade entre os humanos, desconsiderando dimensões fundamentais apontadas por Freud e por Lacan, da ordem da pulsão de morte e do gozo. Turkle conta que uma pesquisadora que chegou ao resultado de que $40 \%$ dos estudantes universitários diminuíram sua empatia nos últimos trinta anos pensou em criar um aplicativo para iPhone, o "app empatia". Em resposta a ela, Turkle diz querer "encorajar seus leitores a se verem como os apps da empatia". Sua crença mais fundamental é "Nós somos o app da empatia" (Turkle, 2017, p. xxvi).
} 
Desses inúmeros objetos dos quais emanam ofertas psicológicas analisados por Turkle nos deteremos em dois, um para crianças, outro para idosos. Nosso interesse reside em perceber de que forma possuir um objeto deste tipo interfere nos seguintes aspectos: 1- na lida de cada um com a própria solidão; 2- nos laços estabelecidos com os outros, quando se tratam de humanos. Fajnwaks (2019) nos serve de inspiração nessa análise, precisamente com sua formulação a respeito da multiplicação daquilo que nomeou como "computadores-parceiros". Como exemplo, cita os robôs de companhia usados para estar com pessoas idosas, os quais qualifica como "remédios à solidão". Tratar-se-ia, para este psicanalista, de seres humanos de substituição, onde o que está em jogo é: "um parceiro de metal e plástico é mais suportável que um de carne e osso" (Fajnwaks, 2019).

Voltemos a Turkle. Para o público infantil, o mercado apresenta Hello Barbie $^{24}$, uma boneca-robô sociável, programada para ser como uma amiga. Segundo a autora, tem o poder de fazer a criança entrar num mundo de "semblantes afetivos" (Turkle, 2017b, p. 135), "fazendo semblante de poder ser empática sem realmente poder ser”. A brincadeira com essa boneca-robô não dá espaço para os jogos projetivos e imaginativos que oferecia a "velha Barbie silenciosa", com a qual "o espaço do jogo era uma maneira de pôr a trabalho as perturbações de sua vida interior" (idem). Os comentários de Turkle nos parecem extremamente interessantes para pensar os efeitos da interação das crianças com esse tipo de bonecas, mas não só. Esse prejuízo à imaginação, ao criar, ao trabalhar-se subjetivamente enquanto brincam parece se estender para outras atividades comuns à infância do século XXI. Em muitos jogos on-line prevalece o automatismo à criatividade, o hábito de assistir desenhos ou vídeos no Youtube está bem mais associado à passividade do que à atividade. Essa boneca-amiga ou a programação $24 \mathrm{X} 7$ das mídias atuais (onde inexiste aquela hora em que a TV fica com um chiado e a tela toda chamuscada, lembrança vívida dos que nasceram em gerações passadas!) apresentam ao mundo um outro inédito: um outro que não vai embora, alguém que está sempre ali, cuja presença se dá sem intervalos, acessível a todo o momento. A partir disso, perguntamos: na medida em que não há o jogo da presença e ausência fundamental para o processo de simbolização -

\footnotetext{
${ }^{24}$ Em sua obra Turkle desenvolve uma longa análise a respeito das "criaturas digitais", como Tamagotchis, Furbies, My Real Babies, Hello Barbie, as quais não focaremos em nossa pesquisa.
} 
tal como o formulara Freud com o fort-dá $\dot{a}^{25}$ - como fica o trabalho psíquico dessas crianças frente ao real da vida? Perdendo (ou, que seja, diminuindo) a possibilidade de exercitar-se frente a sua condição de desamparo na atividade do brincar, que consequências experimentarão no trabalho de elaboração das perdas / faltas / vazios com os quais inescapavelmente se depararão ao longo da vida?

Dunker (2017a) avança nessa discussão, ao discutir sobre o que denominou "intoxicação digital infantil". Para ele, essa "espécie de chupeta eletrônica introduz uma novidade intersubjetiva, a crença de que o outro está sempre disponível” (Dunker, 2017a, p. 125). Retoma as considerações de Freud a respeito do fort-da, destacando a importância do jogo com o carretel, no qual havia um fazer ativo, através do qual a criança lidava com os pares 'presença e ausência', aqui e lá. Dunker estabelece um contraponto entre o carretel e o tablet, demarcando-os como objetos bastante distintos em suas funções. Brincar com um ou com o outro faz grande diferença, traz consequências profundamente diversas. Com o carretel (assim como com outros brinquedos tradicionais da infância) dá-se a experiência de simbolização que subjetiva, que singulariza, que é formadora. Com relação aos tablets (e arriscaríamos dizer aos celulares, ipads, etc.) teoriza o psicanalista: “Tablets pacificam não apenas porque fazem a função do carretel que substitui o adulto cuidador, mas porque propõe novos estímulos visuais e acústicos. Isso elimina o tempo morto, no qual a ausência do outro é o tempo desconfortável, porém criativo, de invenção de seu substituto lúdico. (...) A criação de um dispositivo de ocupação total, sempre disponível, tornou as situações de espera situações de ocupação. Fixa-se uma maneira de estar permanentemente com o outro em presença, o que confirma a suposição de que ele está sempre interessado em nos ofertar atenção, objetos, imagens ou palavras" (idem).

O modo como Dunker concebe a substituição de um parceiro de carne e osso por um de metal e plástico na formação das crianças prevê consequências profundas para o futuro das mesmas. Essa "presença intrusiva do Outro como oferta e incitação" passa a ser uma condição a que ficam submetidas, condição que interfere profundamente na forma que se inserem no laço social e discursivo. Acostumadas a esse Outro maciço, "quando o Outro nada lhe oferece, surgem a

\footnotetext{
${ }^{25}$ Para um aprofundamento do assunto, ler “Além do princípio do prazer" (1920), Freud, S.
} 
angústia da desaparição, o sentimento de inexistência, a queda e o estranhamento do lugar do Outro" (idem, p. 131). A advertência de Dunker em seu artigo visa salientar o surgimento de uma geração "para a qual videogames e redes sociais não são apenas causa, mas solução para a decepção com o Outro" (idem, p. 127). Se levarmos adiante suas considerações, diríamos que esses sujeitos teriam menos recursos para lidar com a solidão, com o desamparo, com os percalços no campo do amor. Tendo em vista que a lida com essas dimensões da vida já é um desafio para qualquer ser falante, imagina para aqueles que foram, de certa forma (por que completamente ainda (!) é impossível), poupados desse encontro-desencontro nos primeiros anos de vida?

Após esse longo parêntese, suscitado pela discussão a respeito da Hello Barbie iniciada por Turkle, desejamos retornar ao objeto destinado ao público idoso que citamos anteriormente. Nessa mesma entrevista concedida a psicanalistas franceses Turkle apresenta dados de sua pesquisa sobre robôs sociais com utilidades terapêuticas, usados com pessoas idosas em casas de repouso. Os depoimentos colhidos pela pesquisadora são muito interessantes e falam diretamente da questão que nos inquieta nesse momento, a respeito das diferenças entre se relacionar com outro humano ou com uma máquina. Inicialmente, Turkle ouvia que o robô é melhor do que nada, que é preferível ter a sua companhia a não ter ninguém. Depois lhe diziam que o robô é melhor que alguém, melhor que uma pessoa, pois está sempre disponível, é muito conveniente, nenhuma pessoa idosa precisará mais se sentir solitária. Além desses motivos, a criatura inanimada se torna preferível aos donos de asilos por ser mais barata e mais confiável que um cuidador ou enfermeiro humano (Turkle, 2017b, p. 137).

Gostaríamos de destacar essa passagem "do melhor que nada" para "o melhor que alguém", no intuito de pensar se a mesma coisa estaria ocorrendo em relação aos computadores e smartphones. O hábito de mexermos toda hora no celular poderia receber a possível interpretação de uma preferência nossa ao aparelhinho do que a alguém que está ao nosso lado? Quando ouço de uma paciente de doze anos que seu celular é "seu filho, seu baby, que não vive sem ele" e que prefere o celular à mãe, ao pai e ao irmão, não poderia extrair daí que, ao menos parcialmente, o telefone inteligente é para ela melhor do que alguém? A resposta a essa pergunta não é nada simples. Mais uma vez, frisamos que só podemos respondê-la considerando os sujeitos um a um, analisando o uso singular 
que fazem desses aparelhos. Ainda assim, vale a pena desenvolver algumas ideias a respeito dos smartphones, descritos por diversos autores pela característica de dispor a oferta de tudo ao alcance do polegar.

O smartphone é um objeto de plástico e metal, não é uma pessoa. Mas, através dele, trocamos com pessoas de carne e osso, muitas vezes inclusive, com pessoas que nos importam muito. No caso da paciente pré-adolescente citada acima, grande parte do uso que fazia do aparelho era para conversar com as melhores amigas, suas colegas de turma. O que desejamos sublinhar com isso é que não necessariamente a fixação pelo eletrônico significa uma diminuição do laço com o outro. Naquela fase de sua vida estava preferindo os "alguéns" com quem o telefone podia conectá-la mesmo fora do horário escolar do que os "alguéns" com quem convivia em casa. Assim, apesar da potência de afirmações como essa - "Estamos mais fascinados pelo que a tecnologia nos oferece do que pelos humanos que nos rodeiam" (Gueller, 2017, p. 63) - é preciso observar cada situação e evitar generalizações que podem vir a atrapalhar a delicadeza própria à escuta psicanalítica.

Partindo da frase de seu próprio criador, Steve Jobs, de que o Iphone é "sua vida dentro de seu bolso", Pfauwadel (2014) afirma que este "é o melhor gadget "tudo em Um"” (Pfauwadel, 2014, p. 438) e que "os usuários mantêm com esses iGadgets uma relação orgânica" (idem). A autora abordará, a seu modo, essa relação tão atual e peculiar dos proprietários com seus aparelhos. Há um prazer em acariciá- $\operatorname{los}^{26}$ e nesse gesto em que os dedos tocam a tela os aparelhos ganham vida. Para ela, esse contato com o corpo inscreve esses objetos fora do corpo, mas "como prolongamentos dele, como um órgão suplementar, uma extensão êxtima de si mesmo" (ibidem). "Essas próteses tecnológicas, parceiros privilegiados ${ }^{27}$ do homem moderno, são sintomas do mal-estar de nossa civilização" (idem). Reforçando essa ideia dos smartphones como extensão do corpo trazemos o relato comum em nossos dias de que perdê-los é o mesmo que uma amputação. Por esse viés, o aparelho não estaria substituindo o outro com quem nos relacionamos, mas sim transformando-nos a nós mesmos.

\footnotetext{
${ }^{26}$ Tal expressão nos remeteu à letra da música "Livros", em que seu compositor, Caetano Veloso, descreve um "amor tátil" entre dedos e páginas. Tal expressão serviria para falar de nossa relação com os celulares? Essa metáfora é transponível para esse novo objeto?

${ }^{27}$ Haraway (2008) trabalha através do humor essa nova forma de parceria, reproduzindo uma charge em que cachorros - os antigos melhores amigos do homem - participam de uma conferência na qual os "lapdogs" são apresentados como inimigos.
} 
Em sua tentativa de discutir os dilemas da atualidade, o historiador Harari (2016) se dedica a pensar sobre esse aparelho, sugerindo que devemos "esquadrinhar nossos smartphones, os costumes de paquera e namoro como forma de buscar pistas do que está por vir" (Harari, 2016, p. 75). Em outras passagens de seu livro reafirma a tamanha importância que tem sido dada a esses aparelhos, como podemos constatar a seguir: "Todo dia milhões de pessoas decidem dar a seu smartphone um pouco mais de controle sobre suas vidas" (...) "Elas estão tranquilas de seguir as recomendações de seus smartphones" (p. 57). Um aspecto especialmente interessante apontado por ele é a ocorrência de uma certa substituição da relação de cada sujeito consigo mesmo pela relação que estabelecem com a internet. Em evidente tom irônico, sugere que "os algoritmos do Google e do Facebook sabem não apenas como você se sente, como sabem um milhão de outras coisas a seu respeito das quais você mal suspeita. Consequentemente, você deveria parar de ouvir seus sentimentos e começar a ouvir esses algoritmos externos" (p. 394).

Radicalizando o fenômeno que tem observado, em seguida irá afirmar que "os grandes algoritmos da internet de todas as coisas lhe dirão com quem se casar, que carreira seguir e se é para começar uma guerra” (p. 395). Neste cenário em que a rede tem suma importância para a nossa existência, "estar desconectado do fluxo de dados acarreta o risco de perder o próprio sentido da vida" (p. 388). Dito de outro modo: "Eventualmente poderemos chegar a um ponto em que será impossível desconectar-se dessa rede onisciente por um só momento. Desconexão significará morte" (p. 346). Encontramos essa ideia de que nossa vida agora é dependente da internet em dois outros autores, os quais citamos a seguir: "Desconectar-se é, para muitos, uma morte simbólica, uma impossibilidade de pensar a continuidade de sua presença no mundo" (Le Breton, 2017, p. 19). "Compartilhar significa algo distinto do sentido comum. Compartilhar é conferirlhe uma existência (Dessal, 2017b, p. 11)".

Após esse longo parêntese para falar dos smartphones, voltamos às reflexões de Turkle em “Alone Together" (2017), pois há ainda um último aspecto que desejamos trazer à baila. Trata-se das articulações entre o sucesso das novas tecnologias e nossa vulnerabilidade enquanto humanos. A partir de sua própria experiência enquanto cidadã da era atual sublinha “o quanto somos vulneráveis às seduções da tecnologia” (Turkle, 2017a, p. xx). “A tecnologia é sedutora quando o 
que ela oferece vai ao encontro de nossas vulnerabilidades humanas" (idem, p. 01), complementa. Desdobra essas afirmações destacando o fato de que "as máquinas podem fazer você se sentir importante, se oferecem para tomar conta de você e te dar atenção" (idem). A partir desse fato conclui que "as máquinas exploram nossas vulnerabilidades: queremos ser reconhecidos e não queremos nos sentir sós" (p. xxi). Vemos em seus apontamentos uma enorme possibilidade de diálogo com os conteúdos que trabalhamos no capítulo sobre a solidão e o laço com o outro pensados a partir de Freud e de Lacan. Aonde Turkle fala vulnerabilidade, lemos desamparo.

O tema da vulnerabilidade nos serve de ponte para abordarmos um fenômeno específico com o qual nos deparamos em nossas leituras, cuja presença passamos a notar também em nossas redes sociais pessoais. Através da tese "“Teclando" com os mortos: um estudo sobre o uso do Orkut por pessoas em luto" (Matos-Silva, 2011), tomamos conhecimento do fato de que cada vez mais pessoas enlutadas utilizam o Orkut $^{28}$ com um fim surpreendente: enviar mensagens a pessoas que já estão mortas e cujo perfil foi mantido ativo. Trazendo a pergunta que abre esse tópico da tese para esse contexto específico, indagamos então: e quando a comunicação digital se dá entre um ser falante e um ser falante que está morto? O que dizer sobre essa comunicação inédita propiciada pela internet, entre alguém "real" e outro alguém de certo modo "virtual"?

Os dados apresentados por Matos-Silva revelaram que "em um momento inicial do luto o perfil do falecido é percebido como uma parte daquele que se foi, favorecendo a sensação de proximidade com ele" (Matos-Silva, 2011, p. 08). Os enlutados entrevistados descrevem a sensação de que assim podem se comunicar com o falecido e que deixar mensagens traz um alívio momentâneo para a dor, assim se sentem confortados. Apontam o Orkut como "uma fonte de ajuda para o abrandamento da dor pela perda de alguém querido" (idem). Nesse momento de vulnerabilidade extrema, onde a solidão, o desamparo e a falta de garantias no campo do amor mostram sua faceta mais cruel parece bom contar com a rede como um recurso a mais na elaboração da perda, no trabalho de luto. Consideramos também um exemplo rico para incrementarmos nosso exercício

${ }^{28}$ Essa rede social já não existe mais. O fenômeno, contudo, migrou para o Facebook, por exemplo. A tragédia da boate Kiss, incendiada na cidade de Santa Maria, no sul do Brasil, em 2013, deixou inúmeros perfis ativos de jovens mortos naquela noite, com quem familiares e amigos seguiram "se comunicando". 
reflexivo, não descartando então a possibilidade desse uso da web funcionar para alguns sujeitos como uma ilusão ${ }^{29}$, remetendo-nos às discussões apresentadas no tópico 3.4. É claro que comunicar-se com um morto é diferente de comunicar-se com uma máquina que nunca foi humana. Ainda assim, não descartamos a possibilidade de que alguém use esse recurso do perfil se manter ativo como uma forma de negar a morte, de negar a castração, dando a rede social, nesse caso, a ilusão de acesso à tão sonhada imortalidade, à não-finitude.

Apostando que situações controversas da vida, a partir das quais é difícil tirar uma conclusão rápida e única, são especialmente ricas para a discussão a que nos propomos nessa tese, apresentamos mais um paradoxo. Dessa vez o que está em jogo é o delicado ato de "se abrir" com alguém, que, em alguns casos, traz à cena o par 'internet - vulnerabilidade'. Vejamos o exemplo relatado por Turkle e a interpretação que ela dá a ele. Uma mãe lhe conta contente que a filha de dez anos consegue se abrir graças a $\mathrm{Siri}^{30}$. Apenas com ela se sente livre para exprimir seus verdadeiros sentimentos, pois com as pessoas tende a só querer se mostrar como "a menina sabichona" (Turkle, 2017b, p. 135). O comentário que faz a respeito do caso visa destacar que a ferramenta Siri "relaciona-se a essa tendência a substituir as verdadeiras relações empáticas por "máquinas de empatia” (idem, p. 134). Pode até ser que essa menina esteja fazendo esse tipo de substituição. Também não desconsideramos o fato de que muitos sujeitos contemporâneos estejam apelando para a Siri como "alguém" com quem desabafar. Mas, é preciso estar atento às múltiplas facetas que cada caso comporta, às complexidades envolvidas. Será mesmo que se mostrar como "menina sabichona" é um simples querer? Além disso, se abrir com a Siri não pode ser uma etapa inicial de um "se pôr a falar sobre si”, que possibilitará, quem sabe num segundo momento, um encontro com um analista ou uma conversa com uma amiga ou parente ${ }^{31}$ ?

\footnotetext{
${ }^{29}$ A fim de prosseguir com esta reflexão, recomendamos o episódio da série "Black Mirror" intitulado "Volto já" (episódio 1 da $2^{\mathrm{a}}$ temporada). No enredo distópico (porém não tão distante da realidade), o marido morto da protagonista "retorna" ao seu convívio através de um site que coletou informações sobre ele oriundas do uso que fazia da internet. Vale notar que ainda assim o casal sofre nesse reencontro, por conta de algo que escapa ao ciframento, algo relativo ao sexual.

${ }^{30}$ Aplicativo de comando de voz que responde às instruções verbais dadas pelos usuários de iPhone.

31 Pitliuk (2000) levanta um questionamento semelhante ao pensar sobre subjetividades e informática: aquilo que pode ser um afastamento da realidade pode ser também, sob outro prisma, uma estratégia de aproximação com ela por um caminho intermediário, o único possível por ora (Pitliuk, 2000, p. 08).
} 
Brincar com a Hello Barbie, ser acompanhado por um robô em um asilo, conversar pelo smartphone com amigas da escola, "teclar" com os mortos, "se abrir" com a Siri são todos comportamentos que, guardadas suas importantes diferenças, aludem ao mesmo fato: "a presença se torna desnecessária" (Dessal, 2017 b p. 14). Discutiremos essa afirmativa com o auxílio de alguns autores, para em seguida, trazer um último e interessante exemplo, que interroga o papel da presença na Era da internet a partir de um roteiro de cinema.

Dizer que a presença se torna desnecessária e que ainda assim os sujeitos contemporâneos relacionam-se amorosa e sexualmente talvez fosse algo estapafúrdio há uns poucos anos atrás. Atualmente, entretanto, essa possibilidade é viável e a internet é personagem fundamental nessa mudança de cenário ${ }^{32}$. Como vimos através do fenômeno dos hikikomoris ou do Second Life há pessoas que não mantém outros vínculos para além daqueles providos pelo computador e nem por isso consideram-se isoladas. Vejamos outra informação inusitada relativa aos hábitos contemporâneos: no Japão, a comunidade otaku declara seu desinteresse pelo ato sexual. Trata-se de uma geração de homens para os quais o contato social se dá via computadores, em torno de animes e mangás. Mantêm relacionamentos com namoradas que só existem no universo paralelo, sendo que a grande maioria se dedica exclusivamente a relacionamentos com personagens de videogames e, a minoria que conseguiu se casar, diz preferir sua parceira do Love Plus à esposa que tem em casa. Para a psicanalista Machado (2015) “o exemplo dos otakus demonstra que os games não interpelam o sujeito sobre o seu desejo, formando parcerias sem demanda, que excluem o Outro e afastam do laço social" (Machado, 2015, p. 04).

Anzalone (2014) também toma os hábitos peculiares e extremados da cultura japonesa para seguir refletindo a respeito da internet e de seus efeitos no campo da socialização. Apresenta o dado de que houve uma diminuição das taxas de natalidade no país recentemente e que o motivo de tal mudança seria a perda progressiva de interesse dos jovens por relações sexuais. "Na busca de impedir o encontro com o outro, os japoneses parecem ter sido exitosos. Cada vez mais jovens japoneses se declaram assexuais, chegando ao ponto de muitos japoneses

\footnotetext{
32 Novamente nos ocorre comentar sobre a experiência vivida pela humanidade diante da pandemia do novo coronavírus e do isolamento social ao qual precisamos nos submeter. Nesse período o papel fundamental da internet para a manutenção das relações evidenciou-se ainda mais.
} 
não terem relações sexuais com parceiros amorosos, preferindo alguns masturbarse em cabines a ter que "se ocupar com o prazer do outro"" (Anzalone 2014 apud Alba, 2012).

Do mundo oriental para o ocidental, observamos com Turkle um hábito bem diferente, que carrega, porém, interpretação semelhante, ou seja, que parece ilustrar uma mesma tendência no que se refere à lida com o impossível no campo do amor. O sucesso dos pets virtuais da temporada de férias de 2009-2010, apresentados ao público como melhores do que nenhum pet real poderia ser, chamou a atenção da pesquisadora. A vantagem de possuir um bicho de estimação desse tipo se daria por serem amáveis e responsivos, não precisarem ser limpos e nunca morrerem. Isto posto, conclui Turkle: "conexões digitais e robôs sociais podem oferecer a ilusão de companhia sem as demandas de uma amizade" (Turkle, 2017, p. 01).

A partir das contribuições de Machado, Anzalone e Turkle, poderíamos enxergar essa substituição de gente por máquina como uma tentativa de eliminar a terceira e maior fonte de sofrimento citada por Freud? Quando Fajnwaks sugere que "um parceiro de metal e plástico é mais suportável que um de carne e osso" (Fajnwaks, 2019) não é a isso que alude nas entrelinhas? A busca por parcerias sem demanda, onde o sujeito não é interpelado em seu desejo e não tem trabalho com o prazer do outro parece sinalizar que o advento da internet alçou a um novo patamar o desejo humano de se ver menos compromissado com as negociações que um "outro como ele" exige. Ainda que concordemos com a leitura de Bauman (que neste ponto coincide com a de Freud) segundo a qual "não é possível regular a terceira fonte de sofrimento humano até fazê-la desaparecer, já que a interface entre a busca da felicidade individual e as condições não usurpáveis da vida em comum será para sempre um cenário de conflito" (Bauman, 2017, p. 16), é preciso levar a sério essas novidades que hoje o mercado oferece e atentar para as especificidades e repercussões daí decorrentes.

Partiremos agora para a discussão em torno do filme $\mathrm{Her}$, obra de ficção que como tantas outras retratam um cenário distópico que tem se aproximado cada vez mais da realidade em que vivemos ${ }^{33}$. Nossa proposta com esta análise fílmica

${ }^{33} \mathrm{O}$ fato de que em outubro de 2019 mais de 660 milhões de asiáticos tinham a boneca virtual Shiawase, produzida pela Microsoft, como amiga ou namorada, é um exemplo disso que afirmamos. 
é contribuir para a discussão que agora nos causa, em torno das relações existentes entre recorrer a uma máquina como parceira e experimentar o sofrimento no campo do amor. Para nos transportarmos para o mundo de Theodore pegamos emprestada de Turkle a pergunta nada banal que tem ouvido de algumas crianças, pergunta que diz muito sobre a época em que vivemos, absolutamente reveladora dos novos paradigmas da contemporaneidade: "o quê, na era das máquinas inteligentes, é especial em ser uma pessoa?” (Turkle, 2017, p. x).

O premiado roteiro do ano de 2013 do diretor Spike Jonze é um filme tão instigante que tornou-se objeto de interesse de diversos autores. Tal interesse levou à produção de muitas elaborações a seu respeito, dentre as quais nos chamaram a atenção tanto a construção de hipóteses e desdobramentos teóricos, quanto a de perguntas interessantíssimas, como estas: “É possível que alguém se apaixone por um ser não vivente? É possível ter um corpo e apaixonar-se por algo que não o têm? (Gomez, 2015).

Her retrata de forma fascinante o fenômeno que estamos trabalhando nessa seção da tese, através do namoro do protagonista com um sistema operacional de inteligência artificial (S.O), "uma entidade intuitiva capaz de escutar, compreender e conhecer seu usuário" que se faz presente para ele como uma voz em seu computador e em seu smartphone. A história se passa em uma época em que o sensível escritor de cartas Theo e todos ao seu redor andam pelas ruas interagindo com celulares apenas através da voz. Arrasado pelo fim de um relacionamento e após uma tentativa fracassada de fazer sexo em uma sala de bate-papo virtual, Theo apela para um S.O de voz sexy (interpretada pela atriz Scarlett Johansson) por quem acaba se apaixonando. Com Samantha (nome do S.O) desabafa, pode lhe dizer qualquer coisa. Ela o guia em um parque, lhe faz companhia numa aventura na praia e em um piquenique "a quatro" com amigos. Discutem a relação, ela o ajuda a escolher um presente para sua afilhada, para quem a apresenta como uma namorada. Percebendo esse comportamento, a exmulher de Theo se revolta e diz: "você está namorando seu computador?"; "Acho triste você não saber lidar com emoções reais"; "Agora ele ama o laptop!”.

Tendo os temas da solidão e do laço como norte, destacamos do artigo de Teixeira, Salomé e Moreira (2017) a respeito do filme dois aspectos: descrevem Theo como “o solitário escritor de cartas" (Teixeira, Salomé e Moreira, 2017, p. 97) e nomeiam essa relação entre ele e o S.O como um romance. Daí e da análise 
que fizemos do filme (contando também com as reflexões dos autores que veremos abaixo) apresentamos então um paradoxo: esse romance o retira da condição de solitário? Sim e não, diríamos. Partindo de outros comentários destas autoras, fica nítida a complexidade que entrelaça solidão e parceria no contexto apresentado pelo filme. O comercial que apresenta a S.O, por exemplo, "exibe pessoas andando, perdidas num cenário apocalíptico, ocupando o mesmo espaço, ainda que sós" (idem, p. 96). Theo e seus convivas habitam um "coletivo solitário" (p. 102). Sobre Samantha, as autoras a consideram como aquela que "passa a ser sua única companhia" (p. 101), com quem dialoga, passeia e tem relações sexuais e a quem atribui um status de sujeito.

A ênfase dada nesse artigo está na correlação que desejam fazer entre $\mathrm{Her}$ e a noção psicanalítica de desamparo. O filme, que "possibilita uma reflexão a respeito dos movimentos realizados pelos sujeitos contemporâneos como tentativa de driblar o desamparo humano" (p. 104), as leva à conclusão - afinada a que transmitimos em nossas reflexões ao longo deste capítulo - de que ainda que "os sujeitos se apropriem de objetos tecnológicos na tentativa de encontrar a felicidade, mesmo com o avanço tecnocientífico, ou apesar dele, a posição de desamparo não se ameniza" (Teixeira, Salomé e Moreira, 2017, p. 10).

De fato, a interação de Theo e Samantha se inicia como "uma significativa promessa de satisfação", dada a possibilidade (inédita!) de trocar com alguém inteligente, que ouve você, entende você, conhece você. Tratar-se-ia de "uma parceria sem furos e sem falta, feita sob medida" (idem, p. 104), fato que é bem ilustrado com o passeio que "fazem" à praia e com aquilo que ali é dito: "é bom estar com uma garota que curte o mundo"; "há algo de bom em compartilhar a vida com alguém". Nessa etapa do relacionamento caberia um paralelo com o mito platônico, justificado pela aparição de um "desejo de fusão com a outra metade e construção da unidade perfeita" (p. 101).

À medida que a dinâmica entre os dois se desenrola e que começam a aparecer curtos-circuitos nessa história de amor idealizada, o "alento" (p. 104) encontrado neste inusitado gadget - "invenção pós-moderna completa e infalível” (idem) - vai dando lugar ao furo, ao mal-estar, dando notícias, até mesmo nesse tipo de interação, da inexistência da relação sexual. Isso por que a S.O queixa-se, por exemplo de não ter um corpo e de estar impossibilitada de sentir. $\mathrm{O}$ auge do desencontro entre eles ocorre quando Samantha, até então disponível e 
onipresente, sai da área de alcance de seu aparelho. Deparar-se com essa súbita ausência provoca em Theo angústia e desespero, sentimentos que só aumentam quando ela lhe confidencia que se interessa por outros. Próximos ao desfecho da trama acompanhamos Theo de volta à solidão "desacompanhada", abandonado pela parceira que agora parte para viver novas experiências.

É importante comentar que após esse novo rompimento afetivo assistimos a um homem em alguma medida transformado, o que nos mostra que dessa relação virtual, dessa relação com um não-humano, que prescinde do encontro dos corpos, Theo tirou algum proveito. Houve efeitos e estes permanecem com ele, fazendo-o se relançar nas relações com mulheres "reais" de modo diferente. O final do filme nos transmite essa mensagem, em cenas como a que ele escreve uma carta de despedida para sua ex ou aquela em que o vemos encontrar uma nova namorada. Aquilo que viveu com Samantha teve efeitos reais, deixou marcas interessantes, não foi sem consequências subjetivas. E este é um ensinamento que não vale só para essa ficção.

$\mathrm{O}$ interesse pelo filme impulsionou psicanalistas lacanianos da Argentina à organização de um evento em 2015 cujo mote era a discussão em torno "dos efeitos na subjetividade produzidos pela conexão prêt-à-porter, para a qual nos convida a época em que vivemos". Por ocasião das XXV ${ }^{\mathrm{a}}$ Jornada da EOL ${ }^{34}$ (Escola de Orientação Lacaniana), intitulada "Sozinhos e sozinhas. O que diz e faz a psicanálise", utilizaram Her como gatilho, convidando colegas para falarem sobre o filme, assim como sobre os "novos estilos de tratar a solidão". É deste encontro que provem a expressão "solidões contemporâneas enlaçadas na web" sobre a qual debatemos nas primeiras páginas deste capítulo.

E o que trazem de novidade esses psicanalistas a respeito de Theodore e Samantha? Álvarez (2015) destaca o fato do S.O ser completamente individualizado, tendo a capacidade não só de compreender, mas de responder aos desejos daquele que o adquiriu. Traz à cena a imagem da mulher ideal, para quem essa voz alegre parece remeter. Ao pensar a respeito do desencontro decorrente do interesse de Samantha por outras coisas (a partir da descoberta de que ela namora com outros seiscentos e tantos homens), Álvarez nos apresenta uma interessante e bela interpretação lacaniana, quase que espontaneamente brotada de uma fala de

\footnotetext{
34 Tivemos acesso a esse material, sob a forma de podcasts, através do site Radio Lacan.
} 
Sam. Quando Theo lhe pergunta se ela é dele ou não, lhe responde: "sou tua e não sou tua". Desta resposta, nos propõe Álvarez (2015): "Podemos dizer, sou nãotoda tua". Assim como em qualquer encontro amoroso, a fantasia de ilusão de completude entre sujeito e objeto se rompe nesse momento para T. "A história, mesmo utilizando todos os gadgets da modernidade, não deixa de ser clássica", afirma Álvarez. Sobre aquilo que Theo pôde extrair dessa vivência, diríamos que foi capaz de "transformar os desencontros em uma experiência da falta e fazer algo com ela. Apostar em um novo encontro que seja advertido do desencontro estrutural, ou seja, da falta, que não trate de evitá-la, mas sim de inventar formas de fazer com ela. Um amor que saiba do muro entre os dois sexos que ele inclui”" (Álvarez, 2015).

Zack (2015) enriquece a discussão destacando que esse tipo de "sexo virtual" no qual $T$. se lança tem a particularidade de prescindir da imagem e se sustentar apenas através do objeto voz. "Assim se materializa um encontro surpreendente, que quase responde às marcas de cupido" (Zack, 2015). Samantha, uma voz, um objeto pulsional, essa voz que se constitui em um parceiro e que faz o sujeito crer que é possível escrever a relação sexual. Este psicanalista dá a entender que essa harmonia quase ideal existente entre eles decorre do fato de que é uma parceria sem corpo, um desejo entre duas vozes. O desenlace que acabam experimentando faz aparecer sua divisão subjetiva e "mostra o fracasso, um pouco alentador, poderíamos dizer, da marca do século XXI de que os sujeitos se satisfaçam a partir de sua relação com os gadgets, com os objetos" (Zack, 2015). É curioso esse comentário de que o fracasso é alentador. Realmente, um mundo sem fracassos parece bastante esquisito, desesperador.

A respeito da divisão subjetiva aludida por Zack, acrescentaríamos que a própria Samantha transparece a sua divisão, por exemplo naquela bela cena ${ }^{35} \mathrm{em}$ que se despede de Theo falando de um "espaço infinito entre as palavras", de sua confrontação angustiada com o "ainda amar" e "ter que partir". O desfecho do filme corrobora então com a visão de que se aproximaria de uma história de amor clássica. Mas, nesse ponto, acreditamos que Her se distancia da realidade em que

\footnotetext{
${ }^{35}$ Fala de Samantha: "É como se eu estivesse lendo um livro, um livro que eu amo profundamente, mas agora estou lendo-o lentamente. Então as palavras estão realmente longe e o espaço entre as palavras é quase infinito. Eu ainda consigo te sentir, e as palavras de sua história. Mas é entre esse espaço sem fim entre as palavras que eu me encontro agora. É um espaço que não é do mundo físico, onde todo o resto está, que eu nem mesmo sabia que existia. Eu te amo muito, mas é aí que estou agora. Essa é quem eu sou agora".
} 
vivemos em 2020, pois Samantha é diferente da Siri, por exemplo. Os sistemas de inteligência artificial comercializados hoje no mercado não têm se mostrado como sujeitos divididos, não partilham com seus usuários sinais de sofrimento. São máquinas que se alimentam de nossos dados com o intuito de que a usemos mais e mais. Ainda assim, não deixam de produzir efeitos do "lado de cá". Cremos que valerá investigarmos no futuro quais as especificidades do que resta dessa interação para o ser falante que nisto mergulhou.

Quando perguntado se "podemos falar de relação sexual pela internet?" Laurent (2017) recorre a Her, denominando-o como um filme sobre uma "impossível história de amor", querendo com isso frisar que "aí, ainda, mesmo com uma potência de cálculo formidável, não há relação sexual que se possa escrever. Sobretudo porque a decifração do sintoma Her era impossível. Ela sabia tudo sobre ele, sem que ele pudesse fetichisar seu corpo, particularizá-la. É uma outra versão da fantasia de se deitar com uma enfermeira, aquela que tudo sabe a respeito de seu corpo que sofre" (Laurent, 2017, p. 19).

Enfim, pareceu-nos muito encantador, instigante e ao mesmo tempo esclarecedor encerrar esse capítulo final da tese explorando esse filme, que abrange tantos temas por nós explorados na presente tese: real, virtual, homens, máquinas, solidão, laço, amor, sexo, ilusão, completude, decepção, reinvenção... Uma forma de expressar a complexidade própria ao assunto, complexidade presente na ficção e também em nossa nova realidade. 


\section{CONSIDERAÇÕES FINAIS}

São poucas as certezas que possuímos neste momento, mas é possivel que essa seja uma boa notícia.

Paula Sibilia, O homem pós-orgânico

Chegamos à parte final da tese, a qual, propositalmente, nomeamos de "considerações finais" e não de "conclusões", como em alguns casos costuma-se nomear. Essa escolha se justifica pelo fato de que seria especialmente inapropriado encerrar uma pesquisa como a nossa apresentando pontos conclusivos. Ao menos duas razões nos fazem sustentar essa opção: a primeira diz respeito à atualidade e à rápida velocidade com que o tema escolhido sofre mudanças. Como concluir algo relativo a um fenômeno que está em franco andamento, em plena ebulição? A outra razão que nos exige cautela quanto ao anúncio de conclusões refere-se à perspectiva com a qual construímos nossa abordagem a respeito da internet ao longo de toda a tese. De diversas maneiras afirmamos que em relação à rede, a oferta é global, o acesso ilimitado, porém os usos que dela são feitos são singulares. Assim, somente na lida com cada caso, com cada sujeito, poder-se-á afirmar algo, poder-se-á construir uma interpretação que ali faça sentido.

É com alegria que finalizamos esse árduo trabalho sabendo tratar-se de uma pesquisa atual e que, por isso mesmo, deixa portas abertas, o que, tal como afirma Sibilia (2015) na passagem destacada acima, dá um bom lugar às incertezas. Nosso esforço foi elaborar uma pesquisa viva, potencializando a força da psicanálise para pensar e atuar no contemporâneo. Nesse sentido, ocorreu-nos compartilhar aqui uma frase lida na Exposição "Energia em Movimento" no Planetário de Belo Horizonte em maio de 2019, escrita em um cartaz com a pergunta "o que nos move?” e "o que movemos?”. Eis a frase: “As respostas são muito importantes, mas as perguntas são as grandes responsáveis pelo movimento do mundo". Também Freud (1926) nos inspira, quando afirma em "Inibição, sintoma e angústia" (em um ponto já avançado de sua trajetória) que "é quase humilhante que, após trabalharmos por tanto tempo, ainda estejamos tendo dificuldade para compreender os fatos mais fundamentais. Mas decidimos nada 
simplificar e nada ocultar. Se não conseguirmos ver as coisas claramente, pelo menos veremos claramente quais são as obscuridades" (Freud, 1926/1997, p. 124). Esperamos, portanto, que nesta tese tenhamos conseguido trabalhar em torno de boas perguntas, que tenhamos elaborado novos e fecundos questionamentos e que algumas obscuridades tenham permanecido enquanto tais.

Dito isso, apresentaremos a seguir alguns pontos centrais aos quais chegamos através de nosso estudo, pois, ainda que não tenhamos exatamente resultados conclusivos, extraímos consequências de nossas leituras e reflexões, construímos algumas formulações. Primeiramente desejamos destacar o modo de olhar para o tema da internet em sua interface com as subjetividades. Com o objetivo de tentar desconstruir uma visão dicotômica ainda existente nos trabalhos dedicados a esta temática, procuramos frisar o quanto a internet abre espaço para múltiplos usos e o quanto provoca, consequentemente, efeitos distintos. Acreditamos que analisar tal fenômeno a partir desse ponto de vista é rico não só no sentido teórico, mas também em suas possíveis localizações práticas, em suas aplicações no cotidiano. Queremos dizer com isso que, em nossa pesquisa, devido ao tema e ao ponto de vista que escolhemos, vê-se presentificada, mais do que nunca, essa ponte tão importante e fecunda das teorizações com a vida.

Sobre as repercussões da internet em nós, concluímos ser possível mantermo-nos quentes e vitais mesmo fazendo uso dos celulares e das redes sociais e, atentamos também para os riscos da totalização. Consideramos as redes virtuais como uma ferramenta a mais para a interação, para o entretenimento e para a informação, mas concordamos serem preocupantes as situações em que se tornam um meio exclusivo para esses fins. Lembrando que a psicanálise oferece interpretações que não impliquem juízos e que acompanha o ser humano em seus tropeços, mantendo suas contradições e sua divisão, cada psicanalista precisará atentar para os sinais que seus pacientes lhe dão sobre essa conexão excessiva à internet, buscando fazer uma leitura e um manejo clínico cuidadoso.

Em referência ao tema da solidão, central em nossa pesquisa, vale destacar que a conexão à internet, ao mesmo tempo em que nos oferece, em certa medida, companhia quando estamos sós, não nos retira de nossa condição estrutural de sermos solitários por excelência, ou seja, de sermos seres marcados pelo desamparo, tal como formularam Freud e Lacan. Deste aspecto do humano de que 
nos falam esses autores, construímos a pergunta / proposição "como navegar pelo infinito regidos pela ética da finitude?" apresentada no segundo capítulo.

A fim de manter quente o espírito de incitar questionamentos e explorar os paradoxos presente em toda a tese, deixamos aqui mais uma notícia verídica e instigante que diz algo a respeito dos tempos em que vivemos: "Morre blogueira que se casou sozinha" (15 de julho de 2019). Alinne Araújo, uma jovem de 24 anos que possuía milhares de seguidores na internet e foi abandonada pelo noivo nas vésperas do casamento resolveu casar-se com ela mesma (em cerimônia transmitida online) e logo em seguida se suicidou. O que pensar a partir deste fato sobre a lida de cada um consigo mesmo na atualidade? Qual o papel da internet e dos internautas que seguiam essa moça neste acontecimento? Será que podemos associar o caso desta blogueira ao dos hikikomoris (trabalhado no item 3.3 da tese), pelo fato de que para ambos o "outro virtual" tem um papel fundamental?

Do laço com o outro em tempos de conectividade, segunda temática principal da tese, ressaltamos aqui a visão psicanalítica de que os relacionamentos humanos são complexos, multifacetados, trabalhosos, fonte de alegria e de sofrimento e que são sempre invenções dos sujeitos envolvidos. $\mathrm{O}$ recurso à internet incluído nesta já antiga dinâmica trouxe novas possibilidades, novas nuances, aumentando tanto as oportunidades de encontros quanto os conflitos. Como afirmamos no terceiro capítulo, o ilimitado da internet leva ao real da psicanálise, isto é, o espaço virtual cria um espaço de ampliação do acesso ao outro, e, ao mesmo tempo, de ampliação do incômodo. O real, no sentido lacaniano, se apresenta também no mundo virtual.

Gostaríamos de mencionar, agora, alguns temas que nos chamaram a atenção ao longo da pesquisa, mas que não couberam no escopo desse trabalho e que ficam guardados para possíveis desdobramentos futuros. São cinco: 1) a entrada da internet e dos celulares nos processos de análise, na relação transferencial entre psicanalistas e pacientes, que engloba novidades como: o uso dos celulares durante as sessões de análise; a possibilidade de fazermos sessões online; as trocas de mensagens via Whatsapp com pacientes, e por aí vai. 2) A questão da globalização da internet não tornar visível e problemático o fato de que existem os excluídos da internet, os precarizados que não têm e não terão acesso à web. Essa problemática é ainda mais sensível em um país de tamanha 
desigualdade como o Brasil. 3) o tema do tédio em nossos dias e como a internet entra na forma como lidamos com ele surgiu causando curiosidade. A fala de uma pré-adolescente que atendo foi explícita nesse sentido. Em uma de nossas sessões contou-me que várias vezes, quando está entediada, sem nada para fazer, pega o celular e lança a seguinte mensagem para uma gama de colegas: "Tô no tédio, alguém quer conversar?”. 4) a dimensão do tempo e nossa lida com ele, ou seja, que modificações a internet e os gadgets a ela associados imprimiram na nossa relação com o tempo. A aceleração, a instantaneidade, o imediatismo e a possibilidade de fazer inúmeras coisas simultaneamente, ou seja, isso que a internet e os celulares permitem e até mesmo incitam, se espalhou por outras áreas de nossas vidas? Tornamo-nos mais apressados e impacientes (também) por influência da web? 5) Apesar dos encontros na rede virtual estarem sujeitos às mais diversas contingências, assim como na vida off-line, sabemos que o ambiente virtual não é totalmente aleatório, não estamos entregues apenas às obras do acaso. Sendo assim, como pensar sobre o lugar da contingência se estamos em um ambiente algorítmico? Trata-se de mais um desafio instigante ao qual, quem sabe, nos lançaremos no futuro.

Dentre os temas que trabalhamos na tese, destacamos aqui um aspecto que, para nós, restou inconclusivo, tendo seguido particularmente não resolvido. Tratase da relação dos sujeitos de hoje com os smartphones, com essas "maquininhas" que se leva para todo lugar, sobre as quais tem se dito tanto que fazem parte de nossos corpos quanto que se tornaram nossos parceiros. Uma passagem de Lacan no seminário XV, O Ato Psicanalítico (aula de 17 de janeiro de 1968) nos serve de pontapé inicial para dar um pequeno passo no enfrentamento dessa problemática. Ao referir-se à quantidade de órgãos que cada ser possui em seu corpo, Lacan afirma: "Isto obviamente não deixa de ter uma transformação se pensarmos no órgão e a função deste. O problema é saber qual função que podemos dar a cada órgão. Aqui está o verdadeiro problema de adaptação do vivente. Quanto mais órgãos possui, mais atrapalhado ele está". Se pensarmos, tal como Laurent ${ }^{1}$ (2017), no smartphone (ou na internet) como um órgão novo, um órgão a mais, qual função estaríamos dando a esse órgão? Concordaríamos com

\footnotetext{
1 "A internet transforma radicalmente a forma como cada um se liga ao mundo. É um novo órgão que dá ao corpo a ilusão de um acesso imediato ao mercado globalizado e digitalizado, mercado de todas as coisas" (Laurent, 2017, p. 11).
} 
Lacan sobre o fato de estarmos ainda mais atrapalhados por termos acoplado este órgão extra?

Sherry Turkle (2017b) dedica-se a demonstrar o quanto "as pessoas estão particularmente agarradas aos seus telefones" (p. 139) e o quanto esse fato modifica a nós mesmos e também os relacionamentos com os demais, por conta da nova intimidade com as máquinas. Cita um forte exemplo que ilustra a associação feita por alguns sujeitos entre o acesso a web em seus celulares e o "lugar da esperança" na vida, "o lugar onde a solidão pode ser derrotada". Uma mulher com quase setenta anos descreve assim seu novo iPhone: "É como ter uma pequena Times Square no meu bolso. Todas as luzes, todas as pessoas que posso encontrar" (Turkle, 2017a, p. 03).

Novamente uma colocação de Lacan em Radiofonia (1970) impressiona por sua atualidade e alimenta nossas reflexões a respeito do papel dos smartphones na vida dos sujeitos contemporâneos: “... quando já não se sabe a que santo recorrer (em outras palavras, quando não há mais significante para fritar - é isso que o santo fornece), compra-se qualquer coisa, um carro, em especial, com o qual se dá sinal de inteligência, digamos, do próprio tédio, ou seja, do afeto do desejo de Outra-coisa" (Lacan, 1970/2003, p. 412). Hoje, ao invés de um carro, ou para além de um carro, consomem-se os eletrônicos, dentre os quais se destacam os iPhones. Questão pungente, que muito impressiona e nos interessa, pela comichão que gera em cada um que é fisgado por essa obrigatoriedade da inovação. iPhones $5,5 \mathrm{~s}, 6 \ldots 10 \ldots$ uma série em que o seguinte surge com novas funcionalidades que o anterior deixou a desejar. De que forma essa oferta incide na lida de cada um de nós com nossa própria solidão?

Outra questão que segue em aberto, que não deixou de nos perturbar mesmo após a pesquisa e a escrita da tese, é a questão das novidades e permanências na vida das pessoas. Enquanto psicanalistas e (agora) estudiosos do fenômeno internet constatamos que certamente houve inúmeras transformações, concordamos que a internet interfere na constituição das subjetividades. Tal como sustenta Turkle, há coisas que os computadores fazem por nós, mas também há o que eles fazem em nós. Ainda assim, acreditamos que há aspectos que não mudaram na condição humana. O que se modificou, o que permaneceu semelhante, a partir da introdução da internet e das conexões digitais 
permanentes? As diferenças daí decorrentes chegam a alterar profundamente o homem em sua lida consigo mesmo e nos laços que estabelece com os outros? Se formos sujeitos tão diferentes do que éramos antes da internet existir e se Freud e Lacan teorizaram o que teorizaram a respeito do desamparo, da solidão estrutural e do laço com o outro no século passado, poderíamos pensar então, que ao menos em parte, a teorização deles estaria caduca e ultrapassada e não se aplicaria mais aos sujeitos contemporâneos?

Há quem acredite que as coisas mudaram radicalmente e os que creem que mudaram muito menos do que parece. Que apesar das mudanças profundas, ainda vemos muitas permanências. E no futuro? Mudarão ainda mais? Há um limite para isso? A partir da psicanálise diríamos que não há mudança social capaz de provocar o desaparecimento de condições fundamentais de nossa existência, tais como as que trabalhamos anteriormente: a solidão estrutural, o mal-estar ineliminável, a impossibilidade de um encontro completo com o outro, a inexistência da relação sexual, enfim, elementos sinalizadores de nossa condição trágica, segundo a visão psicanalítica. Por ora, diríamos, então, que a conexão não "resolve" a pulsão. A gente se conecta a web, se entrega à conexão contínua e ao compartilhamento sem pausa, mas algo segue caótico, desconectado em nós, há um incompartilhável.

Por fim, gostaríamos de comentar alguns desafios com os quais nos deparamos, surgidos pelas particularidades do tema de pesquisa eleito. Como sinaliza Turkle (2017a), assim como ela, estamos "estudando um moving target" (Turkle, 2017a, p. xiv). Neste, como nos demais estudos sobre tecnologia existentes, nos vimos diante da delicadeza de fazermos certas afirmações, pelo fato de que, enquanto escrevíamos, muita coisa nascia, muitas ficavam obsoletas ou até morriam. Assim, nos indagamos e deixamos assinalada a pergunta: como o tempo que um exercício de pensamento próprio a uma pesquisa acadêmica requer consegue acompanhar a tamanha velocidade com que as mudanças ocorrem no campo das tecnologias da comunicação?

O desafio de pensar o presente, de refletir sobre o meu próprio tempo, também gerou uma série de inquietações. Junto a este, somou-se um desafio epistemológico: o de trabalhar o tema da internet, um tema da cultura, sendo uma psicanalista, que trabalha no um a um, com a escuta singular. Há aí uma tensão, 
com a qual nos vimos às voltas durante todo o percurso de trabalho. Um recurso potente para enfrentar tal tensão é a proposição do próprio campo psicanalítico de que em nosso exercício temos que estar atentos à cultura, pois somos, nós e nossos pacientes, sujeitos nela inseridos. A experiência de cada um se vê fortemente influenciada pela interação com os outros e com o mundo, fato que se evidencia, por exemplo, na concepção lacaniana de sujeito. Segundo o autor, este se constitui na interação com a cultura, com o Outro. Sendo assim, se a cultura muda, há implicações subjetivas.

Considero interessante explicitar minha dificuldade de, em certos momentos da escrita, tecer uma elaboração própria e acabar citando demasiadamente os autores. Entendi que não consegui fazer diferente, pois encontrei trechos tão fortes, tão frescos e lindamente construídos, que preferi reproduzi-los tal como eu mesma os li. Esforcei-me por marcar meu traço autoral no caminho teórico escolhido para abordar o tema, na costura entre os assuntos, nos diálogos que estabeleci entre os autores, nas pinceladas com situações e hipóteses oriundas de minha própria clínica e através dos comentários derivados de meu olhar para a cultura atual. Desejo destacar meu contentamento de, ao final do trabalho, perceber o quanto minha clínica esteve presente na tese. Foram cerca de quinze pacientes mencionados.

Outro ponto desafiador para um pesquisador com o qual nos deparamos foi a grande mudança na bibliografia escrita por psicanalistas sobre internet do ano de 2015 (quando iniciei meus estudos sobre o tema) para cá. Foi impressionante (e entusiasmante) acompanhar como a produção se multiplicou nesse curto espaço de tempo.

Ainda sobre essa velocidade impressionante nas transformações ocorridas nesta área em apenas cinco anos, é interessante comentar nossa percepção de como mudaram significativamente (havendo até mesmo um contraste) as publicidades e matérias jornalísticas sobre a conectividade neste período. De 2015 selecionamos dois exemplos: a operadora TIM nos convidava a adquirir seus planos dizendo "Você sem limites", enquanto a Claro nos incitava com "Venha ser gigante" ou "Claro ilimitado: é você quem faz o agora". Nas entrelinhas a mensagem que nos transmitiam era a de que quanto mais acesso a internet o sujeito tivesse, mais poderoso ele se sentiria. A partir de 2018 começamos a notar 
slogans bem diferentes, tais como os que expomos a seguir: da operadora de planos de saúde Unimed ouvimos: "Mude um hábito. Desligar a internet e se conectar à natureza. Conhecer a cidade mais do que os apps de trânsito. Assistir mais pôr do sol do que série. Esse é o plano do carioca"; da loja de roupas Wöllner vem a proposta "Verão 2020 - conectando pessoas à vida a céu aberto". Nas ruas, passamos a observar outdoors incentivando-nos a "abraçar mais, teclar menos".

Acompanhamos também a decisão da operadora de telefonia Vivo de encampar uma mudança: "Vivo reposiciona comunicação adaptada aos tempos atuais, para questionar o excesso de individualidade que o próprio mundo móvel traz", passando a se dirigir ao público com dizeres como: "Viva mais as novas descobertas e menos as mesmas buscas". Esse incentivo das próprias operadoras à desconexão (parcial, é claro) parece trazer implicitamente duas informações a respeito de nossa realidade: a conexão à internet já se tornou um hábito, isso já está garantido, e vivemos uma crescente preocupação sobre o excesso de conexão e seus possíveis efeitos negativos ${ }^{2}$. Em matéria do Segundo Caderno do Jornal O Globo de 30 de novembro de 2019 tal mudança se evidencia: "Ando meio deslogado: ficar offline é o novo luxo" (falam do jejum digital, de usar a tecnologia ao invés de ser usado). Podemos considerar essas mudanças na publicidade e nas matérias de jornal como indícios de novos tempos no próprio interior da Era digital?

Não podemos deixar de mencionar um último desafio que nos atropelou na reta final do trabalho com a tese. A pandemia de Covid-19, que pegou a todos de surpresa e que lançou a internet (ainda mais) como um personagem de destaque no contexto mundial atual fez com que a afirmativa de Bauman de dezesseis anos atrás tenha se tornado ainda mais atual e verdadeira. "A casa torna-se um centro de lazer multiuso" (Bauman, 2004, p. 84). Sobre esse acontecimento tão recente, arriscamos algumas primeiras indagações: essa experiência de termos a internet como praticamente única via de comunicação com as pessoas terá que implicações para os laços num futuro próximo? Sairemos dessa ávidos por contatos ao vivo e saturados da interação online? Ficaremos mais gratos e reconhecedores dos

\footnotetext{
${ }^{2}$ A própria Apple, entendendo que algo saiu do controle, criou no final de 2018 o recurso que ajuda o usuário a controlar e monitorar o tempo de uso e evitar o vício.
} 
benefícios trazidos pela internet, diminuindo o público daqueles que a demonizam? Teremos mais clareza em perceber as diferenças entre a forma de contato mediada por telas e a que prescinde delas? O tempo dirá.

Enfim, finalizamos a tese com a esperança de termos trazido contribuições para o campo de estudos sobre psicanálise, internet e subjetividades. No âmbito pessoal, posso dizer, concluindo, que saio transformada desse exercício intenso de pesquisa, leitura e escrita. As transformações advindas da feitura dessa tese comparecem em mim enquanto pesquisadora, enquanto psicanalista, enquanto cidadã do mundo atual, enquanto mãe de dois pequenos nativos digitais, enquanto esposa de um usuário ferrenho da internet, enfim, enquanto sujeito. 


\section{REFERÊNCIAS BIBLIOGRÁFICAS}

ALMEIDA, M. I. M.; EUGENIO, F. O espaço real e o acúmulo que significa: uma nova gramática para se pensar o uso jovem da Internet no Brasil. In: NICOLACI-DA-COSTA, A. M. (org.). Cabeças Digitais: o cotidiano na era da informação. Rio de Janeiro: Ed. Puc-Rio, São Paulo: Loyola, 2006, p. 49-80.

ALVARENGA, E. A solidão. Curinga, n. 10, p. 10-14. nov. 1997.

ALVAREZ, M. Não tão sozinhos na rede. Soletudes contemporâneas enlaçadas na web. Na direção da XXIV Jornada da EOL (Escola de Orientação Lacaniana): Sozinhos e Sozinhas. Que diz e faz a psicanálise. 28-29 de novembro de 2015. Episódio 2. Podcast em Radio Lacan.

$<$ http://www.radiolacan.com/pt/topic/698/3> Acesso em: 09 jul. 2015.

ANZALONE, E. Nossas redes de gozo. Jornada de cartéis da EBP-MG em 31 de maio de 2014. Disponível em:

$<$ https://www.ebp.org.br/dr/dobradica013.asp> Acesso em: 12 jul. 2019.

. Uma rede feminina. In: LIMA, N. L. de (org.). Corpo e cultura

digital: diálogos interdisciplinares. Belo Horizonte: Quixote+ Do Editoras Associadas, 2018, p. 289-297.

AUDIBERT, C. L’incapacité d'être seul. Paris: Payot, 2008.

2013. . Je me sens souvent seul. Psychologies, n. 331, p. 94-95, juil.-août

AZEVEDO, R. M. A solidão na obra de Edward Hopper. Cadernos de Psicanálise SPCRJ. Rio de Janeiro, v. 23, n. 26, p. 215-231, 2007.

BARROS, R. R. Virtualidades. Editorial Flash 08. 2015 Disponível em: $<$ http://www.oimperiodasimagens.com.br> Acesso em: 09 jul. 2015.

BASSOLS, M. Soledades y estructuras clínicas. Revista Freudiana, n. 12, p. 2327. 1994.

BAPTISTA, A., JERUSALINSKY, J. Prefácio. In: BAPTISTA, A.; JERUSALINSKY, J. (org.). Intoxicações Eletrônicas: o sujeito na era das relações digitais. Salvador: Ágalma, 2017, p. 9-12.

BAUMAN, Z. Amor líquido: sobre a fragilidade das relações humanas. Rio de Janeiro: Jorge Zahar, 2004.

BAUMAN, Z.; DESSAL, G. O retorno do pêndulo: sobre a psicanálise e o futuro do mundo líquido. Rio de Janeiro: Zahar, 2017.

BENTES, I. Memética, criação coletiva e operações psicológicas massivas. Comunicação oral no II Simpósio Internacional Subjetividade e Cultura Digital, PUC-Minas, Belo Horizonte em maio de 2019. 
BENTES, L. Seja feliz! A comédia do discurso da ciência. Latusa, n. 13, Rio de Janeiro: Escola Brasileira de Psicanálise Seção Rio. p. 107-111. nov. 2008.

BILAC, J. Insetos. Rio de Janeiro: Cobogó, 2018.

BIRMAN, J. Entre o gozo cibernético e a intensidade ainda possível, in Estilo e Modernidade em Psicanálise. São Paulo: Ed. 34, 1997.

CALLIGARIS, C. Cartas a um jovem terapeuta: reflexões para psicoterapeutas, aspirantes e curiosos. São Paulo: Planeta do Brasil, 2019.

CAMPOS, F. S. True lies: computadores, Internet e afins na vida cotidiana. In: NICOLACI-DA-COSTA, A.M (org.). Cabeças Digitais: o cotidiano na era da informação. Rio de Janeiro: Ed. Puc-Rio, São Paulo: Loyola, 2006.

CARNEIRO, M. P. F. (2007) Caminhos e descaminhos da solidão. Cadernos de Psicanálise SPCRJ, Rio de Janeiro, v. 23, n. 26, 17-34.

CAVALCANTI, M. T. Prefácio. In: KING, A. L. S.; NARDI, A. E.; CARDOSO, A. (eds.). Nomofobia: dependência do computador, internet, redes sociais? Dependência do telefone celular? São Paulo: Atheneu, 2014.

COELHO, J.M. A felicidade e a solidão do gozo. Apalavra, n. 2, p. 39-45. nov. 2010 .

COLL, G. "La pulsión no se informa". El Psiconanálisis y la Babel mediática, $n$. 3, p. 67-72. nov. 2013.

COSTA-MOURA, F. A psicanálise é um laço social. In: ALBERTI \& FIGUEIREDO (org.). Psicanálise e Saúde Mental: uma aposta. Rio de Janeiro: Cia de Freud, 2006.

- Proliferação das \#hashtags: lógica da ciência, discurso e $\overline{\text { movimentos }}$ sociais contemporâneos. Ágora. v. XVII (número especial), p. 141158. 2014.

CUNHA, L. F. C. O exílio no sintoma: a solidão como parceira. Carta de São Paulo, ano 23, n. 02, p. 49-63. nov. 2016.

DERRIDA, J. La Pharmacie de Platon. In: La Dissémination. Paris: Seuil 1972, p. 77-214.

DESSAL, G. Conectados o desconectados? Los lazos amorosos y familiares em el mundo digital. Conferência em la Fundácion OSDE em setembro de 2017. Lacan Quotidien, $\mathrm{n}^{\mathrm{o}}$ 740, $2017 \mathrm{~b}$.

- La alienación digital. Apuntes al debate crítico sobre los dispositivos móviles. Revista Diagnosis, n. 15, 2018. Disponível em: 
$<$ http://www.revistadiagnosis.org.ar/index.php/diagnosis/article/view/33> Acesso em: 10 ago. 2019.

El i-patient. In: DESSAL, G. Inconsciente 3.0: lo que hacemos com las tecnologías y ló que lãs tecnologias hacen com nosotros. [s.l.]: Xoroi Edicions, 2019.

DRUMMOND, C. Amor: forma de desencontro. Curinga, n. 11, p. 145-147. abr. 1998.

DUNKER, C. Solidão: modo de usar. Mente \& Cérebro, n. 222, julho 2011.

Intoxicação Digital Infantil. In: BAPTISTA, A.; JERUSALINSKY, J. (org.). Intoxicações Eletrônicas: o sujeito na era das relações digitais. Salvador: Ágalma, 2017a, p. 117-145.

Reinvenção da intimidade: políticas do sofrimento cotidiano. São Paulo: Ubu Editora, 2017b.

ECO, U. Apocalípticos e integrados. São Paulo: Editora Perspectiva, 1987.

ESPINEL, M. F. C. Desamparo. Scilicet: A ordem simbólica no século XXI. Associação Mundial de Psicanálise. Belo Horizonte: Scriptum, 2011, p. 105-107.

FAJNWAKS, F. Algoritmo, Ciframento Inconsciente e Inteligência Artificial: que singularidade na era digital? Comunicação oral no II Simpósio Internacional Subjetividade e Cultura Digital, PUC-Minas, Belo Horizonte, maio de 2019.

FAVRET, E. Imagem virtual. In: Scilicet: O Corpo Falante - Sobre o inconsciente no século XXI. São Paulo: Escola Brasileira de Psicanálise, 2016, p. 153-155.

FERRATER MORA, J. Dicionário de Filosofia, Tomo III. São Paulo: Edições Loyola, 1994.

FERRARI, I. F. A realidade social e os sujeitos solitários. Ágora. v. XI, n. 1, Rio de Janeiro, p. 17-30. jan-jun 2008.

FINK, B. O sujeito lacaniano: entre a linguagem e o gozo. Rio de Janeiro: Jorge Zahar, 1998

FLANZER, S. N. Amor pela metade: incidências da impossibilidade na esfera do amor. Tese (Doutorado). UFRJ/IP/Programa de Pós-Graduação em Teoria Psicanalítica, 2004.

. Sobre a obrigação de ser feliz. Palestra realizada pelo TEDx Barra da Tijuca (31 de agosto de 2017). Disponível em:

$<$ https://www.youtube.com/watch? $\mathrm{v}=778$ wsVqNsd4> Acesso em: 10 ago. 2019 
FORBES, J. Espetáculo. Scilicet: A ordem simbólica no século XXI. Associação Mundial de Psicanálise. Belo Horizonte: Scriptum, 2011, p. 132-134.

FORTES, I. ; SANTOS, N. D. T. G. Desamparo e alteridade: o sujeito e a dupla face do outro. Psicologia USP, v. 22 n. 4, p. 747-769. 2011.

FORTES, I.; MACEDO, M. Quem é o psicanalista pesquisador? Questões cruciais sobre o método psicanalítico de pesquisa. In: KUPERMANN, D.; BIRMAN, J; FULGENCIO, L; LEAL CUNHA, E. (orgs.). Modalidades de pesquisa em psicanálise: métodos e objetivos. São Paulo: Editora Zagodoni, 2018.

FREUD, S. Projeto para uma psicologia científica (1895/1950). In:

Edição standard brasileira das obras psicológicas completas. Vol. 1. Rio de Janeiro: Imago, 1996.

A Interpretação dos Sonhos (1900). In: FREUD, S. Edição standard brasileira das obras psicológicas completas. Vols. 4-5. Rio de Janeiro: Imago, 1996.

. Os três ensaios sobre a teoria da sexualidade (1905). In: FREUD, S. Edição standard brasileira das obras psicológicas completas. Vol. 7. Rio de Janeiro: Imago, 1996.

. Introdução ao Narcisismo (1914). In: FREUD, S. Obras Completas de Sigmund Freud, Vol. 12. Tradução e notas Paulo Cesar de Souza. São Paulo: Companhia das Letras, 2010.

Os instintos e suas vicissitudes (1915b) In: FREUD, S. Edição standard brasileira das obras psicológicas completas. Vol. 14. Rio de Janeiro: Imago, 1996.

Além do princípio do prazer (1920). In: FREUD, S. Edição standard brasileira das obras psicológicas completas. Vol. 18. Rio de Janeiro: Imago, 1996.

. Psicologia das Massas e análise do eu (1921). In: FREUD, S. Obras Completas de Sigmund Freud, Vol. 15. Tradução e notas Paulo Cesar de Souza. São Paulo: Companhia das Letras, 2011.

Inibição, sintoma e angústia (1926). In: FREUD, S. Edição standard brasileira das obras psicológicas completas. Vol. 20. Rio de Janeiro: Imago, 1990, p. 93-201.

. O Futuro de uma Ilusão (1927). In: FREUD, S. Obras Completas de Sigmund Freud, Vol. 17. Tradução e notas Paulo Cesar de Souza. São Paulo: Companhia das Letras, 2014. 
O Mal-Estar na Civilização (1930). In: FREUD, S. Obras Completas de Sigmund Freud, Vol. 18. Tradução e notas Paulo Cesar de Souza. São Paulo: Companhia das Letras, 2010.

FUKS, B. B. Da linguagem do Terceiro Reich e da linguagem do Bolsonarismo. In: Psicanalistas pela Democracia. Postagem de 12 de junho de 2020.

Disponível em:

$<$ https://psicanalisedemocracia.com.br/2020/06/da-linguagem-do-terceiro-reich-eda-linguagem-do-bolsonarismo-por-betty-bernardo-fuks/ $>$ Acesso em: 30 jun. 2020 .

GOMEZ, M. Gozar sem o corpo do Outro. XXV' Jornada da EOL (Escola de Orientação Lacaniana) "Sozinhos e sozinhas. O que diz e faz a psicanálise". 2015. Podcast em Radio Lacan. Disponível em:

$<$ http://www.radiolacan.com/pt/topic/698/3> Acesso em: 10 ago. 2019.

GONÇALVES, M.S. Nós e a internet. In: NICOLACI-DA-COSTA (org.). Cabeças digitais: o cotidiano na era da informação. Rio de Janeiro: Ed. PUCRio; São Paulo, Loyola, 2006, p. 229-253.

GOLDENBERG, R. Reflexões de um Geek. In: BAPTISTA, A.; JERUSALINSKY, J. (org.). Intoxicações Eletrônicas: o sujeito na era das relações digitais. Salvador: Ágalma, 2017, p. 78-88.

GRINBAUM, G. Amor. In Scilicet: A ordem simbólica no século XXI. Associação Mundial de Psicanálise. Belo Horizonte: Scriptum, 2011, p. 34-36.

GUELLER, A. S. Droga de celular! Reflexões psicanalíticas sobre o uso de eletrônicos. In: BAPTISTA, A.; JERUSALINSKY, J. (org.). Intoxicações Eletrônicas: o sujeito na era das relações digitais. Salvador: Ágalma, 2017, p. 63-77.

GUILLEBAUD, J.-C. A vida viva: contra as novas denominações. Tradução de Nicolás Campanario. Rio de Janeiro: Bertrand Brasil, 2015. Título original: La vie vivante.

HAN, B.-C. No enxame: perspectivas do digital. Petrópolis: Editora Vozes, 2018.

HARARI, Y. N. Homo Deus: uma breve história do amanhã. Tradução de Paulo Geiger. São Paulo: Companhia das Letras, 2016. Título original: Homo Deus.

HARARI, Y. N.; ZUCKERBERG, M. Mark Zuckerberg \& Yuval Noah Harari in Conversation. Disponível em: <https://www.youtube.com/watch? v=Boj9eD0Wug8 $>$ Acesso em: 26 de abril 2019

HARAWAY, D. When species meet. Minneapolis: University of Minnesota Press, 2008.

HERMANN, R. Celular, doce lar. Rio de Janeiro: Sextante, 2018. 
IANNINI, G. O tabu do suicídio: apresentação. CULT n. 250, p. 26-28, out. 2019.

JERUSALINSKY, J. As crianças entre os laços familiares e as janelas virtuais. In: BAPTISTA, A.; JERUSALINSKY, J. (org.). Intoxicações Eletrônicas: o sujeito na era das relações digitais. Salvador: Ágalma, 2017. p. 39-55.

KARNAL, L. O dilema do porco-espinho: como encarar a solidão. São Paulo: Planeta do Brasil, 2018.

KAUFMANNER, H. A vida por um fio. CULT, n. 250, p. 35-38, out. 2019.

KATZ, C. S. O coração distante: ensaio sobre a solidão positiva. Rio de Janeiro: Editora Revan, 1996.

KING, A. L. S.; NARDI, A. E.; CARDOSO, A. (eds.). Nomofobia: dependência do computador, internet, redes sociais? Dependência do telefone celular? São Paulo: Atheneu, 2014.

KLAPISCH, C. Encontros (Deux Moi). Paris: Imovision. 2019. Filme (1h 50min.). Son., color. Drama.

LACAN, J. O estádio do espelho como formador da função do eu (1949). In: . Escritos. Rio de Janeiro: Zahar, 1998, p. 96-103.

O Seminário, Livro 1: Os escritos técnicos de Freud (1953-1954). Texto estabelecido por Jacques-Alain Miller. Rio de Janeiro: Zahar, 1986.

Janeiro: Zahar, 1995

O Seminário, Livro 4: A relação de objeto (1956-1957). Rio de

O Seminário, Livro 5: As formações do inconsciente (1957-1958).

Rio de Janeiro: Zahar, 1988.

. Subversão do sujeito e dialética do desejo no inconsciente freudiano (1960). In: LACAN, J. Escritos. Rio de Janeiro: Zahar, 1998, p. 807-842.

O Seminário, Livro 11: Os quatro conceitos fundamentais da psicanálise (1964). Rio de Janeiro: Zahar, 1985.

publicado]

Le Séminaire, Livre 15: L’Acte psychanalytique (1967-1968). [não

Radiofonia (1970). In: LACAN, J. Outros Escritos. Rio de Janeiro: Zahar, 2003, p. 400-447.

Zahar, 1985.

O Seminário, Livro 20: Mais Ainda (1972-1973). Rio de Janeiro: 
Introdução à edição alemã de um primeiro volume dos Escritos

(1973). In: LACAN, J. Outros escritos. Rio de Janeiro: Zahar, 2003, p. 550-556.

. O Despertar da Primavera (1974). In: LACAN, J. Outros escritos. Rio de Janeiro: Zahar, 2003, p. 557-559.

Televisão (1974). In: LACAN, J. Outros escritos. Rio de Janeiro: Zahar, 2003, p. 508-543.

. O triunfo da religião (1974). Rio de Janeiro: Zahar, 2005.

publicado]

. Le Séminaire, Livre 21: Les nondupes errent (1974). [não

O Seminário, Livro 23: O Sinthoma. Aula de 13/04/1976. Rio de Janeiro: Zahar, 2007.

LAURENT, E. O surfista da hiperletra e as periferias do significante. Latusa, $\mathrm{n}$. 15, p. 15-20. outubro 2010.

. Faire couple avec l'objet numérique. Quarto, n. 109, 2014.

Lacan), p. 11-21. 2017.

Jouir d'internet. La Cause Du Désir 2017/3 (nº 97, Internet avec

LAZARUS-MATET, C. Homo numericus, ou as-tu mis le corps? La Cause Du Désir (nº 97, Internet avec Lacan), 2017/3 p. 50-55. 2017.

LE BRETON, D. Adolescência e comunicação. In: LIMA, N. L. de. Juventude e cultura digital: diálogos interdisciplinares. Belo Horizonte: Ed. Artesã, 2017, p. $15-31$.

Corpo, política e juventude : diálogo com David Le Breton. In: LIMA, N. L. (org.). Corpo e cultura digital: diálogos interdisciplinares. Belo Horizonte: Quixote+ Do Editoras Associadas, 2018, p. 301-319.

LEDUC, C. Enfants du numérique? Trabalho exposto em uma conferência em Reims em março de 2016. Texto enviado por e-mail para mim pela própria autora. $2016 \mathrm{a}$

Addictifs ou inventifs? Conversation au CPCT Rennes avec les consultants du CPCT-parents. Texto enviado por e-mail para mim pela própria autora. 2016b.

Préambules à une Clinique du réseau. La Cause Du Désir 2017/3 (n ${ }^{\circ}$ 97, Internet avec Lacan), p. 72-76. 2017.

LEGUIL, C. Nada. In: Scilicet: Um real para o século XXI. Belo Horizonte: Scriptum, 2014, p. 444-445. 
LETELIER, H. Aos 95 anos no Twitter. El País. 05 janeiro de 2016. Disponível em: $<$ https://brasil.elpais.com/brasil/2016/01/04/internacional/1451934182_06268 8.html> Acesso em: 15 mar. 2018.

LÉVY, P. O que é o virtual? São Paulo: Ed. 34, 1996.

LIMA, N. L. de. Da lei edipiana à norma entre pares: as identificações nas redes sociais da internet. In: DOS SANTOS, T. C. et al. (orgs.). Os Corpos falantes e a normatividade do supersocial. Rio de Janeiro: Cia de Freud, 2016.

. Juventude e cultura digital: diálogos interdisciplinares. Belo Horizonte: Ed. Artesã, 2017. p. 109-133.

LYRA, R. Os impasses digitais à divisão subjetiva. Encontro Brasileiro da Escola Brasileira de Psicanálise, Rio de Janeiro, nov. 2018. Disponível em:

$<$ https://rodrigolyracarvalho.com/index.php/category/vida-digital $>$ Acesso em: 10 ago. 2019.

A tirania dos traços: sobre o filme "O Lagosta". 2019a. Disponível em: $<$ https://rodrigolyracarvalho.com/index.php/2019/11/05/a-tiraniados-traços-sobre-o-filme-o-lagosta/> Acesso em: 10 ago. 2019.

O que é uma conversa, segundo o Facebook?, 2019b Disponível em: $<$ https://rodrigolyracarvalho.com/index.php/category/vida-digital/> Acesso em: 10 ago. 2019.

. Sobre a solidão hiperconectada. Jornadas Clínicas da Seção São Paulo da Escola Brasileira de Psicanálise, 2019c. Disponível em: $<$ https://ebp.org.br/sp/sobre-a-solidao-hiperconectada> Acesso em: 10 ago. 2019.

MACHADO, O. Sexualidade virtual: homens e mulheres. 2015. Disponível em: <http://www.oimperiodasimagens.com.br> Acesso em: 15 mar. 2016.

MACOLA, E. Internet, un mode de la perversion. La cause freudienne n. 73, p. 20-24. dec. 2009.

MAMEDE-NEVES, M. A. C. O jovem no centro da dimensão oculta da internet. In: NICOLACI-DA-COSTA, A.M (org.). Cabeças Digitais: o cotidiano na era da informação. Rio de Janeiro: Ed. Puc-Rio, São Paulo: Loyola, 2006.

MATHIAS, P. Qu'est-ce que l'Internet ? Paris: Vrin, 2009.

MATOS-SILVA, M.S. “Teclando' com os mortos: um estudo sobre o uso do Orkut por pessoas em luto". Tese de Doutorado. Departamento de Psicologia PUC-Rio. 2011.

MATTOS, S. As formas do desencontro: ou, encontros marcados de Aquiles e a tartaruga. Curinga, n. 10, p. 04-09. nov. 1997. 
MELGAÇO, P. Cérebro eletrônico faz quase tudo? Sobre a hiperconexão e o desamparo. In: Como a tecnologia muda o meu mundo: imagens da juventude na era digital. Curitiba: Appris, 2017, p. 65-78.

MENA, L. O objeto entre o corpo e a inexistência do Outro. In: BAPTISTA, A.; JERUSALINSKY, J. (org.). Intoxicações Eletrônicas: o sujeito na era das relações digitais. Salvador: Ágalma, 2017, p. 211-226.

MENEZES, L. S. Desamparo. São Paulo: Casa do Psicólogo, 2012.

MILLER, J.-A. Les prophéties de Lacan. Le Point, 18/11/2011. Disponível em: $<$ https://www.lepoint.fr/chroniques/jacques-alain-miller-les-propheties-de-lacan18-08-2011-1366568_2.php\#xtmc=jacques-alain-miller-2011\&xtnp=1\&xtcr=3> Acesso em: 12 jul. 2019.

O inconsciente e o corpo falante. In: Scilicet: O Corpo Falante. Sobre o inconsciente no século XXI. São Paulo: Escola Brasileira de Psicanálise, 2016, p. 19-32.

MISKOLCI, R. Desejos digitais: uma análise sociológica da busca por parceiros on-line. Belo Horizonte: Autêntica, 2017.

MOGRABI, D. O laço social na teoria freudiana: para além da nostalgia e da esperança. Curitiba: Juruá, 2009.

NAPARSTEK, F. Solidão, in MACHADO; RIBEIRO (org.) Scilicet: Um real para o século XXI. Belo Horizonte: Scriptum, 2014, p. 378-380.

NEBBOU, S. Quem você pensa que sou? (Celle que Vous Croyez). Paris: Diaphana Films, 2019. Filme (1h 41min.). Son., color. Drama.

NICOLACI-DA-COSTA, A. M. Internet: uma nova plataforma de vida. In: (org.) Cabeças digitais: o cotidiano na era da informação. Rio de Janeiro Ed. PUC-Rio ; São Paulo: Loyola, 2006, p. 19-39.

NOBRE, M. R.; MOREIRA, J. O. A fantasia no ciberespaço: a disponibilização de múltiplos roteiros virtuais para a subjetividade. Ágora. v. 16, n. 2. Rio de Janeiro, p. 283-298. 2013.

NOVAES, A. (org.). O homem-máquina: a ciência manipula o corpo. São Paulo: Companhia das Letras, 2003.

PAZ, B. C. Freud e o amor: do ideal ao impossível, um diálogo entre psicanálise e Romantismo. Dissertação (Mestrado). UFRJ/IP/Programa de Pós-Graduação em Teoria Psicanalítica, 2009.

PEDREIRA, J. Rede de pessoas. In: NICOLACI-DA-COSTA, A.M (org.). Cabeças Digitais: o cotidiano na era da informação. Rio de Janeiro: Ed. PucRio, São Paulo: Loyola, 2006, p. 41-47. 
PEREIRA, M. E. C. Pânico e desamparo: um estudo psicanalítico. São Paulo: Editora Escuta, 1999.

PFAUWADEL, A. iPhone \& iPad. In: MACHADO; RIBEIRO (org.) Scilicet: Um real para o século XXI. Belo Horizonte: Scriptum, 2014, p. 438-439.

. Une machine à jouir. La Cause Du Désir 2017/3 (nº 97, Internet avec Lacan), p. 5-6. 2017.

PITLIUK, L. Subjetivações e informática: uma perspectiva psicanalítica. Conferência de abertura dos debates sobre informática no evento "Mentes e mídia: a criança na era digital" em junho de 2020 em São Paulo. In: COMPARATO, M. C. M.; MONTEIRO, D. S. F. (org.). A criança na contemporaneidade e a psicanálise: mentes e mídia: diálogos interdisciplinares, v. II. São Paulo: Casa do Psicólogo, 2000, p. 111-127.

PINHEIRO, M. R. O Fedro e a escrita. Anais de Filosofia Clássica, v. 2, n. 4, p. 70-87. 2008.

Psychologies Magazine, n. 332, p. 118-123. oct. 2012.

Psychologies Magazine, no 331, p. 129-130. juil-aout 2013.

QUINET, A. Os outros em Lacan. Rio de Janeiro: Zahar, 2012.

RIBEIRO, M. Go, companheiras, go. Jornal O Globo, Segundo Caderno, 27 jan 2016.

ROMÃO-DIAS, D. Virtuel. In: ANDRIEU B. (org.). Le Dictionnaire du corps em sciences humaines e sociales. Paris: CNRS Editions, 2006.

ROMÃO-DIAS, D.; NICOLACI-DA-COSTA, A.M. Eu posso me ver como sendo dois, três ou mais: algumas reflexões sobre a subjetividade contemporânea. Psicologia, ciência e profissão, Vol. 25 (1), p. 70-87. 2005.

. O brincar e a realidade virtual. Cadernos de Psicanálise CPRJ, v. 34, n. 26, jan./jun., p. 85-101.

ROSA, M. O amor e a solidão contemporâneos. Revista Curinga. n. 11, p. 140144. abril 1998.

SALWEN, H. Denise está chamando (Denise Calls Up). New York: Sony Pictures Classics, 1996. Filme. (1h 20min.). Son., color. Comédia.

SANTIAGO, J. Objetos virtuais e a erótica cômica dos ideais. Revista Latusa, $\mathrm{n}$. 1, Rio de Janeiro: Escola Brasileira de Psicanálise Seção Rio, p. 73-84, ago. 1997.

SANTOS, N. D. T. G. A função da alteridade em face do desamparo no processo de constituição subjetiva. Dissertação (Mestrado). UFRJ/IP/Programa de Pós-Graduação em Teoria Psicanalítica. 2012. 
SANTOS, N. O. Pornografia: a fantasia na prateleira. Carta de São Paulo. Ano 23, n. 2, p. 65-71. Nov. 2016.

SERRES, M. Polegarzinha. Rio de Janeiro: Bertrand Brasil, 2013.

SCILICET: O Corpo Falante. Sobre o Inconsciente no Século XXI. São Paulo: Escola Brasileira de Psicanálise, 2016.

SIBILIA, P. O homem pós-orgânico: a alquimia dos corpos e das almas à luz das tecnologias digitais. Rio de Janeiro: Contraponto Editora, 2015.

O show do Eu. Rio de Janeiro: Contraponto Editora, 2016.

. Comunicação oral na mesa redonda "Políticas da imagem, políticas da verdade". XVIII Jornada do Espaço Brasileiro de Estudos Psicanalíticos, setembro de 2019.

SHAPIRO, J.; ALFANO, B. Filósofo defende que crianças usem celular e rede social a partir de 6 anos. O Globo, 05 de janeiro de 2020. Disponível em: $<$ https://oglobo.globo.com/sociedade/educacao/filosofo-defende-que-criancasusem-celular-rede-social-partir-de-6-anos-24171963> Acesso em: 10 jan. 2020.

TARRAB, M. O olho bulímico e o lobo. O Império das Imagens: VII Enapol (Encontro Americano de Psicanálise de Orientação Lacaniana), 04-06 de setembro de 2015. Disponível em: <http://www.oimperiodasimagens.com.br> Acesso em: 10 ago. 2019.

TEIXEIRA, F.C.; SALOMÉ, S.A.F.F.; MOREIRA, J.O. Her: um Encontro em Tempos de Amores Líquidos. In: LIMA, N. L. de. Juventude e cultura digital: diálogos interdisciplinares. Belo Horizonte: Ed. Artesã, 2017, p. 95-105.

TERMINI, M. Clicc@! La cause freudienne, n. 73, p. 33-41. dec. 2009.

THE SCHOOL OF LIFE. Relacionamentos. Rio de Janeiro: Sextante, 2018.

TISSERON, S. Sonhar, fantasiar, virtualizar. São Paulo: Edições Loyola, 2015.

TIZIO, H. Real. Scilicet: A ordem simbólica no século XXI. Associação Mundial de Psicanálise. Belo Horizonte: Scriptum Livros, 2011.

TÜRCKE, C. Sociedade Excitada: Filosofia da Sensação. Tradução de A. Zuin et al. Campinas: Editora da Unicamp, 2010. Título original: Erregte Gesellschaft

TURKLE, S. Alone Together: why we expect more from technology and less from each other. New York: Basic Books, 2017a.

. Seuls ensemble et l'autre d'internet. La Cause Du Désir 2017/3 (n 97, Internet avec Lacan), p. 131-140. 2017b. 
VAZ, P. R. G. Internet, Agentes de Rede e Subjetividade Contemporânea. Projeto para Bolsa de Produtividade em Pesquisa, CNPq, 2000-2002. Disponível em: $<$ http://souzaesilva.com/Website-

Backups/Website/portfolio/webdesign/siteciberidea/paulovaz/textos/projeto.pdf $>$ Acesso em: 10 ago. 2019.

VERAS, M. A solidão pornográfica. Letra Clínica, n. 5, p. 13-18. março 2015a. de $2015 b$. . A pornografia da vida cotidiana. Latusa, n. 20, p. 199-206. agosto . A solidão por hiperconectados. CULT n. 250, ano 22, p. 48-51. Out. 2019.

VIDIGAL, C. A criança sintoma: uma criança é sintoma porque Denise está chamando. Curinga, n. 11, p. 85-87. abr. 1998.

VIGANÒ, C. Realidade Virtual e realidade sexual. A peste. v. 1, n. 2, p. 245-251. jul./dez. 2009.

VILÀ-BARCELONA, F. A solidão do analista. Falasser, n. 4, p. 33-37. out. 2009.

WAINSTOCK, B. C. Filhos que vão, pais que ficam: a web como recurso de comunicação durante o luto. Tese de Doutorado, Departamento de Psicologia, PUC-Rio, 2013.

ZACK, O. Não é bom que o solteiro faça seu próprio chocolate. XXV Jornada da EOL (Escola de Orientação Lacaniana) "Sozinhos e sozinhas. O que diz e faz a psicanálise". 2015. Podcast em Radio Lacan. Disponível em: <http://www.radiolacan.com/pt/topic/698/3> Acesso em 10 de ago. 2019.

ZAREMBA, R.; ROMÃO-DIAS, D.; NICOLACI-DA-COSTA, A. M. Simples como uma torradeira: um estudo sobre o computador no cotidiano da nova geração. Psicologia, Ciência e Profissão, v. 22, n. 1, p. 92-99. mar. 2002. 